\section{La subtitulació}

com a eina per a la cooperació:

El cas de São Tomé i Príncipe

\section{Maria Montroy Ferré}

Directores:

Irene de Higes Andino Anna Marzà Ibáñez

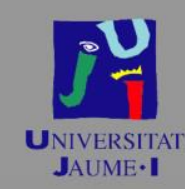

Castelló de la Plana,

novembre de 2020
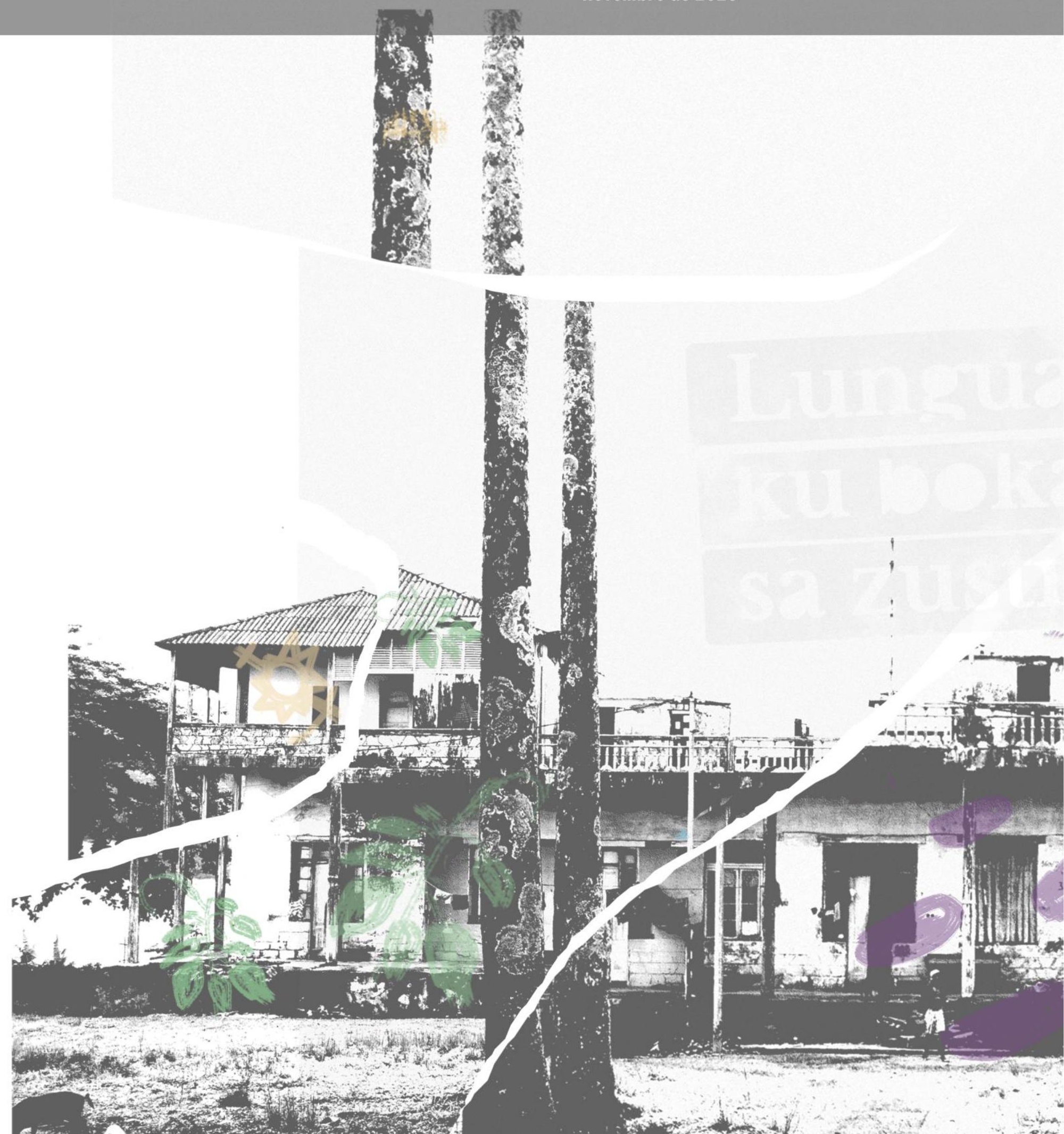
Disseny de la coberta: Adel Abugren Asensi ( 


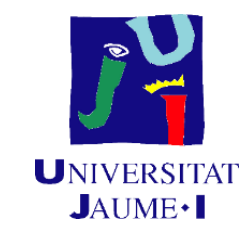

Programa de Doctorat en Llengües Aplicades, Literatura i Traducció

Escola de Doctorat de la Universitat Jaume I

La subtitulació com a eina per a la cooperació: el cas de São Tomé i Príncipe

Memòria presentada per Maria Montroy Ferré per a optar al grau de doctora per la Universitat Jaume I

Doctoranda: Maria Montroy Ferré

Directores: Irene de Higes i Anna Marzà
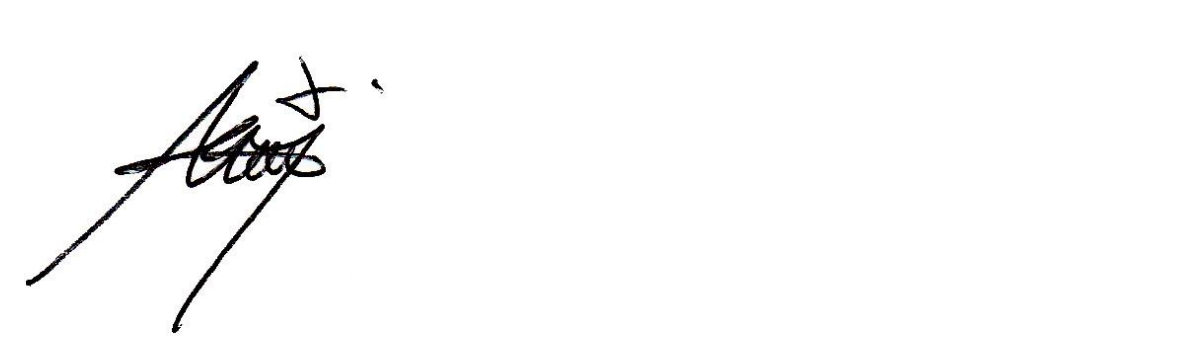
ANNA| Digitallysigned MARZA| MA MARZA|IBAÑEZ IBAÑEZ $\begin{array}{ll}\text { Date: } 2020.10 .26 \\ 09: 52: 06+00^{\prime} 0^{\prime}\end{array}$

Castelló de la Plana, novembre de 2020 

Aos sorridentes santolas, que tanto me deram 

-Belo país o teu, Tomé. Belo como um sonho. Tão belo que não o compreendo. A beleza é quase sempre misteriosa. Acho isso bom. Também não compreendemos os sonhos, e por isso nos fascinam.

José Eduardo Agualusa. O livro dos camaleões. 



\section{AGRAIIMENTS}

Són moltes les persones que han contribuït perquè poguera finalitzar aquesta tesi i a qui he d'agrair que m'hagen acompanyat durant els últims anys. Aquesta llista, però, han d'encapçalar-la els meus pares, sense el suport dels quals no estaria escrivint aquestes línies; el meu germà i les meues germanes, que han sigut sempre l'espill on m'he volgut mirar; i els meus nebots i nebodes, que tenen la capacitat d'alegrar-li el dia a qualsevol.

Gràcies a les directores d'aquesta tesi per haver-se atrevit a endinsar-se en aquest treball i per la paciència que han tingut durant aquests anys.

Als amics i les amigues que han estat pendents de l'evolució de la tesi i de la salut mental de l'autora durant el procés. Algunes telefonades van resultar realment sanadores.

Por su inestimable colaboración, gracias de todo corazón a Cooperación Bierzo Sur en general y a Carmen Álvarez Vilas en particular, así como a todos los expertos y expertas que participaron en las entrevistas y grupos de discusión desde València, Ponferrada y Euskadi.

Obrigadíssima à Cristina Vieira: por seres a melhor vizinha e madrinha do mundo.

Pela generosidade que tiveram, obrigada a todas as pessoas que entrevistei na ilha de São Tomé. Dêsu paga. Também à Dra. Cosma Aguiar, ao Dr. Eduardo Malé e ao Dr. Esterline de Género, pela ajuda desinteressada. 
À minha querida Aida. Tenho tantas saudades das nossas conversas! Obrigada, amiga, por não dizer-me nunca adeus.

Ana Paula, foste essencial durante a minha primeira visita ao país porque me deste as respostas que precisava antes que eu soubesse quais eram as perguntas. Obrigada por me ensinar a deixar a minha mente europeia atrás, por partilhar tantas anedotas incríveis e por apresentar-me as pessoas adequadas no momento idóneo. Pela boleia, a cachupa, o piquenique, a tartaruga, Terra Papagali, e $O$ jardineiro do rei. Tomara que todas as pessoas te vissem com os meus olhos: tão sábia, tão forte, tão capaz.

Ao sr. Joaquim, por tantos momentos queridos que levo no coração. Guardo na memória uma noite estrelada a cantar-me Menino da rua. Às vezes ainda me visita em sonhos, dançando ritmos cabo-verdianos...

And last but not least, a tu, que no vols que t'anomene però que, per a ser sincers, hauries de compartir autoria amb mi. Has sigut el meu càmera, tècnic de so, dissenyador gràfic, informàtic, infermer, psicòleg, corrector, crític, editor i xofer. Saps millor que ningú que aquesta tesi m'ha costat, literalment, suor i (moltes) llàgrimes. Només tu pots entendre què significa per a mi perquè hem tastat junts el safu i la fruta pão, el sabor del cacau cru, el calulú en dies de pluja, el café, café. Hem plorat i hem rist junts. Hem crescut. Gràcies per ser el millor company de viatge, per buscar balenes en l'horitzó i per haver sentit amb mi o canto do ossobó. 



\section{ÍNDEX}

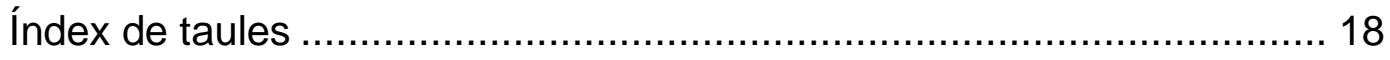

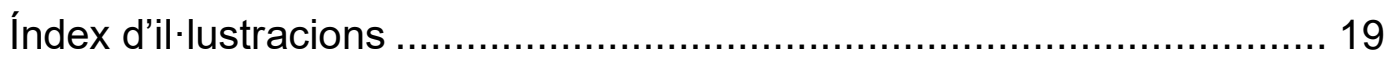

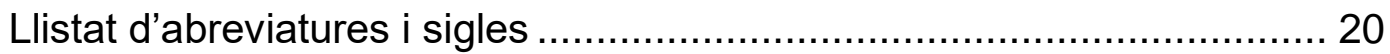

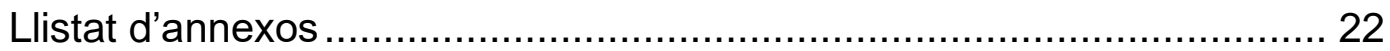

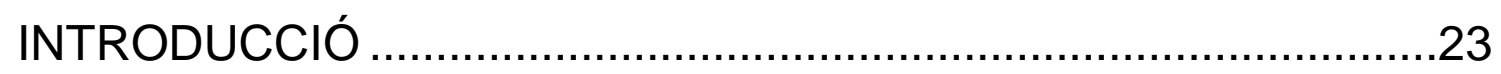

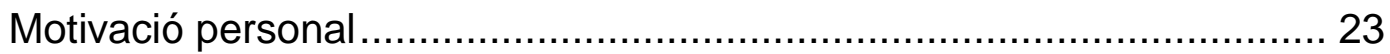

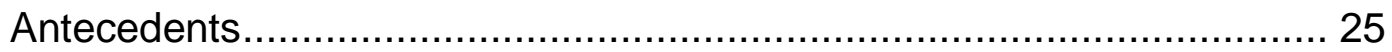

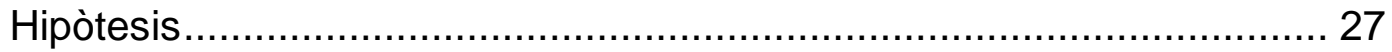

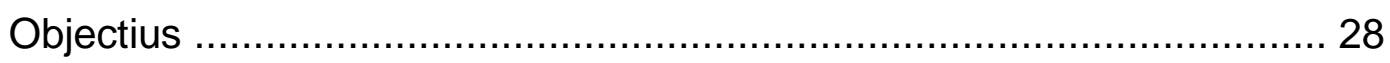

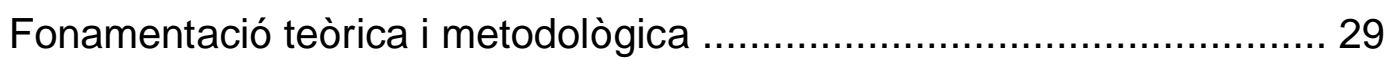

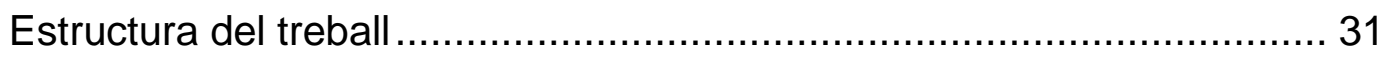

1. LES LLENGÜES ............................................................. 34

1.1 Conceptes lingüístics .............................................................. 34

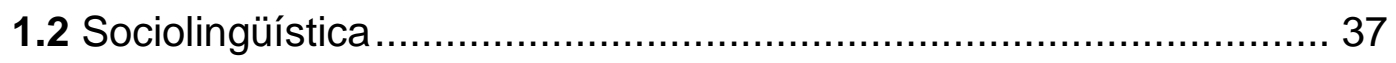

1.3 La UNESCO i les Ilengües minoritzades ....................................... 41

1.4 Planificació lingüística............................................................. 50 
1.4.1 Revitalització lingüística.

1.4.1.1 Un exemple de revitalització lingüística: el nàhuatl d'El Salvador 58

\section{LA TRADUCCIÓ AUDIOVISUAL: LA} SUBTITULACIÓ .64

2.1 El procés de la subtitulació 69

2.2 Convencions bàsiques de la subtitulació 70

2.3 La subtitulació en l'aprenentatge de llengües 72

2.4 La subtitulació a Àfrica 78

3. L'ETNOGRAFIA .85

3.1 Història, conceptes, i definicions 85

3.2 Elements de la investigació etnogràfica 91

3.2.1 Pla d'acció 92

3.2.2 La triangulació 95

3.3 Investigacions etnogràfiques sobre São Tomé i

Príncipe 96

4. LA COOPERACIÓ 100

4.1 Història i evolució 100 
4.2.1 Cooperació al desenvolupament 104

4.2.1.1 Educació per al desenvolupament. 107

4.2.1.2 Cooperació lingüística 110

4.2.2 Sostenibilitat 113

4.2.3 Justícia social 115

4.3 Cooperació i traducció 117

4.4 Cooperació i cinema 121

5. SÃO TOMÉ I PRÍNCIPE

5.1 Context històric de São Tomé i Príncipe 130

5.2 Les llengües de São Tomé i Príncipe 133

5.2.1 Els criolls a l'illa de São Tomé en l'actualitat 139

5.2.1.1 Angolar 139

5.2.1.2 Capverdià 140

5.2.1.3 Forro .141

5.2.2 Els criolls a Príncipe en l'actualitat 143

5.2.2.1 Capverdià 143 
5.2.3 Les llengües criolles als mitjans de comunicació

5.3 L'educació a São Tomé i Príncipe. 148

5.4 Cooperació a São tomé i Príncipe 154

5.4.1 Persones ancianes a São Tomé i Príncipe 157

6. METODOLOGIA 162

6.1 La metodologia etnogràfica aplicada en aquesta tesi 162

6.2 Participants 166

6.2.1 Participants de São Tomé i Príncipe 167

6.2.1.1 Persones ancianes 168

6.2.1.2 Persones no ancianes 169

6.2.2 Participants experts 173

6.3 Instruments 174

6.3.1 Entrevistes 175

6.3.1.1 Entrevistes a persones ancianes 175

6.3.1.2 Entrevistes a persones no ancianes .182 
6.3.1.3 Entrevistes a experts en cooperació lingüística 185

6.3.2 Grups de discussió 187

6.3.2.1 Grup de discussió amb experts en

$\mathrm{Cl}$. 189

6.3.2.2 Grup de discussió amb experts en TAV 192

6.3.3 Notes de camp 194

6.4 Mètode d'anàlisi de dades 196

6.5 Subtitulació adaptada del vídeo 199

6.6 Temporització .205

7. RESULTATS 209

7.1 Resultats de les entrevistes a persones ancianes de São Tomé. 209

7.2 Resultats de les entrevistes a persones no ancianes de São Tomé 215

7.2.1 Menors de 20 anys .216

7.2.2 Entre 20 i 30 anys .220

7.2.3 Entre 30 i 40 anys .224

7.2.4 Entre 40 i 50 anys .227 
7.3 Resultats dels grups de discussió i entrevistes amb experts

7.3.1 Experts en $\mathrm{Cl}$ .235

7.3.2 Experts en TAV 245

7.3.3 Experts en cooperació lingüística .252

8. CONCLUSIONS 262

8.1 Conclusions del treball al terreny i de l'opinió dels experts .262

8.1.1 La situació de les persones ancianes .263

8.1.2 La percepció del forro .265

8.1.3 La cooperació lingüística .268

8.1.4 L'ús de la TAV 271

8.2 Proposta en base als resultats obtinguts .283

8.3 Consecució d'objectius i validació d'hipòtesis .286

8.3.1 Consecució d'objectius .286

8.3.2 Validació d'hipòtesis .294

8.4 Futures línies de recerca .298

BIBLIOGRAFIA 305 


\section{ÍNDEX DE TAULES}

Taula 1. Grup tshivenda. Estudi Kruger et al. (2007)

81

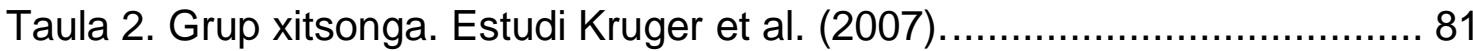

Taula 3. Percentatge de parlants per llengua en l'era post-colonial a São Tomé i Príncipe (1981-2012)

Taula 4. Percentatge de parlants per llengua segons edats (2012) 138

Taula 5. Percentatge de subtitulació i doblatge emés a RTP Internacional i RTP África (2015-2018).

Taula 6. Centres Educatius a São Tomé i Príncipe. 152

Taula 7. Guió inicial de les entrevistes als ancians 176

Taula 8. Guió general de les entrevistes a persones no ancianes 182

Taula 9. Entrevista amb experts en cooperació lingüística 186

Taula 10. Guió del grup de discussió amb experts en $\mathrm{Cl}$ 190

Taula 11. Guió del grup de discussió amb experts en TAV 193

Taula 12. Convencions espacials 201

Taula 13. Convencions temporals 202 
Taula 14. Convencions ortotipogràfiques

Taula 15. Convencions lingüístiques .204

Taula 16. Temporització de la investigació 207

Taula 17. Valoració d'ítems dels experts en Cl. 245

Taula 18. Valoració d'ítems dels experts en TAV. .251

Taula 19. Valoració d'ítems dels experts en cooperació lingüística. .257

Taula 20. Conclusions obtingudes 280

ÍNDEX D'IL·LUSTRACIONS

II-lustració 1. Pla d'Acció de l'ICLPA (UNESCO, 2006, p. 78) 44

II.lustració 2. Esquema dels conceptes de cooperació 129 
AECID …............... Agència Espanyola de Cooperació

AEXCID .................. Agencia Extremeña de Cooperación Internacional al Desarrollo

BM Banc Mundial

CAD Comité d'Ajuda al Desenvolupament

$\mathrm{Cl}$ Cooperació Internacional

CID Cooperació Internacional per al Desenvolupament

ED Educació per al Desenvolupament

FILTA. Film In Language Teaching Association

FMI Fons Monetari Internacional ICLPA Intergovernmental Conference on Language Policies in Africa

KITA Kenya Interpreters and Translators Association

OCDE Organització per a la Cooperació i Desenvolupament Econòmic

ODM Objectius de Desenvolupament del Mil.leni 
ODS... .. Objectius de Desenvolupament Sostenible

ONG .. Organització No Governamental

ONU Organització de les Nacions Unides

OP Objectiu principal

OS Objectiu secundari

SABC South African Broadcasting Corporation

SPS Subtitulació per a Persones Sordes

STP São Tomé i Príncipe

TAV Traducció Audiovisual

TVS Televisão Santomense

UNESCO ...United Nations Educational, Scientific and Cultural Organisation 
LLISTAT D'ANNEXOS

Annex l: Transcripcions del vídeo inicial de les entrevistes als ancians

Annex II: Vídeo final de les entrevistes als ancians

Annex III: Transcripcions de les entrevistes a persones no ancianes

Annex IV: Transcripcions de les entrevistes i grups de discussió amb experts

Annex V: Frases sobre cooperació lingüística

Annex VI: Testimonis de São Tomé i Príncipe sobre llengua

Annex VII: Testimonis de São Tomé i Príncipe sobre subtitulació 


\section{INTRODUCCIÓ}

\section{MOTIVACIÓ PERSONAL}

La motivació per fer aquesta tesi naix, per una banda, d'una inquietud pel voluntariat i pel continent africà que m'acompanya quasi des de la infantesa; per altra banda, és fruit de la formació que vaig rebre a la Llicenciatura de Traducció i Interpretació. La contínua cerca d'una ONG (Organització No Governamental) amb la qual m'identificara i em permetera col-laborar a llarg termini em va portar a conéixer Cooperación Bierzo Sur i, amb ella, São Tomé i Príncipe. Els primers anys va portar-se a terme una col-laboració més bé passiva, mitjançant la traducció de documents i com a assistent a les jornades que s'organitzaven. Aquestes activitats em van permetre seguir de prop les ventures i les desventures dels projectes que es realitzaven al terreny i també conéixer algunes de les característiques i les necessitats del país. Durant aquest procés em preguntava què podia fer la traducció al context de São Tomé i Príncipe i quasi em negava a pensar que l'única possibilitat era traduir documents per encàrrec d'alguna ONG (activitat, sens dubte, important). Des d'àmbits tan diversos com la construcció, el turisme o l'esport s'havien desenvolupat projectes amb molt bons resultats $i$ amb perfils de voluntaris tan variats com mestresses de casa, sanitaris o paletes. $\mathrm{Hi}$ hauria espai per a la traducció?

Em va resultar especialment impactant conéixer de primera mà els projectes que s'havien realitzat amb persones ancianes. Els voluntaris i les voluntàries em van explicar 
que moltes persones ancianes de São Tomé i Príncipe viuen apartades, abandonades per familiars i, de vegades, maltractades per acusacions de fetilleria. Em van explicar les condicions en què vivien, fins $i$ tot aquells que estaven tutelats per una altra organització; les escenes tan denigrants que es van trobar i la dificultat de treballar en aquest àmbit. De vegades tendim a pensar en Àfrica com un país $i$, des de la meua ignorància, havia donat per fet que a Àfrica els avis i les àvies eren persones de respecte a les comunitats i que tothom els tenia en compte. Però Àfrica no és un país, i cada nació ha de considerar-se de manera individual. São Tomé i Príncipe té una història, una cultura i una societat pròpies, i havia d'entendre'l fora de les generalitats i les pressuposicions que es fan sobre Àfrica.

Una vegada al terreny, i com a parlant d'una llengua minoritzada, em vaig interessar per les llengües que es parlaven al país, a més del portuguès, i en quina situació es trobaven. De seguida em van parlar del forro amb el qualificatiu de língua de velhos. Curiosament, però, també vaig identificar un cert orgull $i$ interès per la llengua, fins $i$ tot per part de persones que no la parlaven. Llavors la resposta a la pregunta que m'havia estat fent quasi va arribar sola. Les persones ancianes es troben, d'una banda, relegades de la societat, sovint oblidades per les famílies $i$, algunes d'elles, carregant a l'esquena els prejudicis, les agressions i les acusacions de fetilleria. En canvi, d'altra banda, són les persones que millor coneixen la llengua, la biodiversitat, els trets culturals i els remeis tradicionals del país. Milloraria la percepció social de les persones ancianes si s'intentara revitalitzar el forro mostrant-les com a mestres o font dels coneixements? Podria funcionar l'ús de la subtitulació en aquest aspecte?

Així doncs, vaig emprendre aquest nou enfocament en la investigació de la Traducció Audiovisual (TAV) per 
comprovar si seria possible utilitzar-la com a ferramenta activa en Cooperació Internacional $(\mathrm{Cl})$, en aquest cas, a l'illa de São Tomé, i emmarcada en un projecte que permetera la inclusió del forro (en risc de desaparició) i de les persones ancianes a través de la subtitulació. Cal tindre en compte que la tesi que es presenta no pretén transmetre la idea que la subtitulació és l'únic mètode mitjançant el qual es pot revitalitzar el forro i millorar la situació de les persones ancianes, ni tampoc que pot complir aquesta funció sense el suport d'altres disciplines. Ben bé el contrari: el que es pretén amb aquest treball és posar el focus en la utilitat i l'impacte que pot tindre la utilització de material audiovisual traduït al context del forro i dels ancians i les ancianes de São Tomé i Príncipe juntament amb altres iniciatives d'organitzacions 0 institucions que tinguen el mateix objectiu. És a dir, una ferramenta més per remar en la mateixa direcció.

Vivim en un món de desigualtats que necessita el compromís de les persones que l'habitem per sortejar les dificultats i encaminar-se cap a una realitat més justa i ètica per a totes i tots. En aquest camí, no ens podem permetre desestimar noves propostes i iniciatives que, de manera transversal, plantegen possibilitats de millora d'algun aspecte de la societat. La subtitulació és una proposta més que s'adapta a l'era tecnològica en què vivim i que, amb el suport i la col-laboració d'altres disciplines, es presenta com una eina innovadora per a planificar projectes de cooperació.

\section{ANTECEDENTS}

Com a antecedents d'aquesta investigació es pot trobar, per una banda, la subtitulació en l'aprenentatge de llengües i, per una altra banda, la cooperació lingüística. Les 
investigacions sobre l'efecte de la subtitulació en l'aprenentatge de llengües han obtingut resultats molt positius, i se centren sobretot en l'aprenentatge de llengües estrangeres i en quines destreses aporta cada tipus de subtítol, així com en la creació de noves plataformes web que utilitzen altres modalitats de TAV, com ara el doblatge, l'audiodescripció, etc. com a recurs per a l'estudiantat i el professorat.

Pel que fa a la cooperació lingüística, cal destacar el treball de l'organització Garabide, que treballa en la cooperació entre diferents entitats públiques de països amb minories lingüístiques per a intercanviar experiències, en la promoció i estructuració de la cooperació lingüística a escala universitària i de centres d'investigació, i la gestió de les experiències de la societat civil i les iniciatives populars.

Partint d'aquestes bases de treball, aquesta tesi suposa la incorporació de la TAV al camp de la cooperació com una ferramenta activa per a assolir diferents objectius de manera transversal. En aquest cas, la revitalització del crioll forro de la mà de la visibilitat de les persones ancianes que, a més, ocuparien un rol social de saviesa en ser les protagonistes dels vídeos. A São Tomé i Príncipe, aquesta activitat suposaria una forma innovadora de treballar en favor d'aquest col-lectiu i d'afavorir la revitalització del forro. En l'àmbit social, suposaria situar els ancians en un paper de rellevància, ja que és d'ells de qui s'aprèn i es dona importància a allò que ells coneixen: la seua llengua. A més, la subtitulació permet que puguen incloure's més objectius de treball segons la temàtica dels vídeos: poden contenir cançons o històries, però també receptes, explicacions sobre la biodiversitat del país, etc.

A escala general, aquesta tesi ofereix la possibilitat de tindre en compte la TAV a l'hora de plantejar projectes 
de cooperació, i pot donar peu a altres investigacions sobre aplicacions alternatives de la TAV en aquest camp. L'aplicació de la TAV en aquest sentit, ha de planificar-se tenint en compte el context específic del país o la zona on es vaja a treballar, i açò obri un ampli ventall de possibilitats per a la investigació: quines modalitats són més adients en cada cas, les possibles modificacions en les convencions de subtitulació segons l'objectiu del projecte, l'ús de la subtitulació com a ferramenta per a l'alfabetització, etc.

\section{HIPÒTESIS}

La premissa d'aquesta investigació és que la subtitulació pot ser una ferramenta beneficiosa als treballs de sensibilització en l'àmbit de la cooperació. En aquest cas, parlem sobre l'abandonament que viuen els ancians a São Tomé i Príncipe i sobre el risc d'extinció del crioll forro amb tot el que això comporta: pèrdua d'aspectes culturals, desigualtats dels seus parlants respecte als monolingües de portuguès, etc.

A partir d'aquesta base, formulem les següents hipòtesis:

1. La presentació de temes com l'abandonament dels ancians, o el risc d'extinció del crioll forro a través d'un mitjà audiovisual no generarà rebuig per part dels grups de persones entrevistades.

2. La subtitulació de les entrevistes als ancians servirà perquè el públic es replantege la seua percepció sobre els temes tractats: llengua, ancians i tradicions. 
3. La subtitulació podrà utilitzar-se com a ferramenta de $\mathrm{Cl}$ per a treballar en favor de la revitalització del forro i la sensibilització envers les persones ancianes de manera transversal, i els experts consultats apreciaran la possibilitat d'emprar una nova eina (la subtitulació) en contextos de Cooperació Internacional.

\section{OBJECTIUS}

L'objectiu principal (OP) d'aquesta tesi és valorar si la subtitulació de vídeos podria utilitzar-se com a eina de cooperació activa per a la integració d'ancians o per a programes de revitalització lingüística.

Per tal d'aconseguir complir aquest objectiu, i adaptant-nos a la situació de São Tomé i Príncipe, de les persones ancianes i del crioll forro, es proposen una sèrie d'objectius secundaris (OS):

OS1: Esbrinar la percepció cultural i lingüística d'un grup d'ancians parlants de forro.

OS2: Analitzar les reflexions i les opinions de persones no ancianes residents a São Tomé sobre els comentaris dels ancians respecte a la situació que viuen, l'ús de la llengua i els trets culturals del país.

OS3: Esbrinar la percepció que tenen de la subtitulació les persones participants de São Tomé i Príncipe. 
OS4: Analitzar la reacció de diferents agents relacionats amb la cooperació i amb la TAV envers la subtitulació com a eina de $\mathrm{Cl}$ dins el context de São Tomé i Príncipe.

\section{FONAMENTACIÓ TEÒRICA I METODOLÒGICA}

Aquesta tesi abraça molts àmbits de coneixement diferents que la conformen com un estudi interdisciplinari que beu de diverses metodologies $\mathrm{i}$ fonts bibliogràfiques per a poder assolir els objectius marcats de la forma més adient. És una investigació que naix des d'un interès inicial per la cooperació $i$, per tant, els coneixements teòrics sobre aquesta activitat són indispensables per al desenvolupament del treball, començant per la definició, la història i els principals conceptes (v. 4). Aquestes dades han servit per a concretar la intervenció que es proposa en aquesta tesi i quines són les seues possibilitats després d'analitzar també la relació entre la cooperació i la traducció (v. 4.3), la cooperació lingüística (v. 4.2.1.2) i la cooperació i el cinema (v. 4.4), així com les necessitats de cooperació a São Tomé i Príncipe i les persones ancianes (v. 5.4).

També han sigut indispensables certs coneixements sobre les llengües, com ara algunes nocions bàsiques de sociolingüística (v. 1.1) que han servit per a comprendre les situacions que es donen a les zones on hi ha llengües en contacte $i$ de quina manera poden afectar a les llengües i als seues parlants; la bibliografia consultada sobre planificació i revitalització lingüística (v. 1.3 i 1.3.1), que mostra quines són les accions que poden prendre's per a treballar en favor d'una llengua, quins factors s'han de tindre en compte i els exemples d'alguns casos com la revitalització del nàhuatl d'El Salvador (v. 1.3.1.1); i, per últim, la 
postura i les accions que pren la UNESCO envers la qüestió lingüística, que és un exemple institucional reconegut i amb prestigi social que aposta obertament per la diversitat i la conservació lingüística arreu del món per l'impacte que tenen les llengües a la vida dels seus parlants, a la cultura de les societats i a la comprensió de la biodiversitat (v. 1.2).

Evidentment, aquesta tesi tampoc s'entén sense la TAV, ja que les possibilitats de la subtitulació, la seua metodologia, els tipus i els costos (v. 2 i 2.1) en comparació amb altres modalitats de TAV, així com la seua utilitat en l'aprenentatge de llengües (v. 2.3) i l'exemple d'altres activitats relatives a la subtitulació desenvolupades al continent africà (v. 2.4), han servit de base per a elaborar la proposta principal d'aquesta tesi.

Per últim, São Tomé i Príncipe ha sigut escenari de diverses investigacions etnogràfiques a causa de les seues característiques i pel ventall de temàtiques que s'hi poden estudiar, des de les merament històriques o culturals fins a la flora $i$ la fauna o les possibilitats farmacèutiques de les plantes medicinals (v. 3.3). Ja que l'etnografia suposa estudiar els costums, la cultura i les formes de vida dels pobles, i aquest estudi també s'emmarca dins la proposta d'aquesta tesi, és clar que aquesta investigació també compta amb matisos etnogràfics, especialment pel que fa a la metodologia. El que aquesta ciència aporta al present estudi és, per una banda, un pla d'acció específic que inclou el treball de camp, una planimetria, les entrevistes, les gravacions, etc., (v. 3.1 i 3.2) i algunes tècniques com la triangulació (v. 3.2.1), que ajuden a valorar els resultats obtinguts a les investigacions etnogràfiques. A més d'aquest pla d'acció, l'etnografia porta implícita una metodologia concreta del treball de camp, que contempla la immersió de l'investigador/a al terreny on es realitza l'estudi, de quina manera s'ha de realitzar i com s'ha de relacionar amb les persones que són 
objecte d'estudi (v. 3.1 i 3.2). Tots aquest elements propis de l'etnografia resulten indispensables per l'enfocament adoptat en aquesta tesi.

\section{ESTRUCTURA DEL TREBALL}

El capítol 1 (Les Llengües) d'aquesta tesi suposa una aproximació a alguns conceptes relacionats amb les llengües que es repetiran al llarg del treball o que hi estan relacionats, començant pel significat de certs termes que resulten fonamentals per a comprendre el desenvolupament del forro a São Tomé i Príncipe. A continuació, es presenta la sociolingüística i aquelles característiques d'aquesta ciència que es relacionen amb la tesi. També es revisa la postura de la UNESCO envers les llengües, en què consisteix la planificació lingüística i la revitalització d'una llengua.

Al capítol 2 (La Traducció Audiovisual: la Subtitulació) s'exposen els fonaments de la TAV i, més concretament, de la subtitulació, que motiven aquesta tesi: el procés de la subtitulació, les convencions bàsiques, la seua utilitat en l'aprenentatge de llengües, i la subtitulació a l'Àfrica.

El capítol 3 (L'Etnografia) es dedica a l'etnografia. Després de revisar la història i alguns conceptes referents a aquest camp, al capítol s'expliquen els elements de la investigació etnogràfica, molts dels quals han servit per a desenvolupar la metodologia d'aquesta tesi, i exemples d'altres investigacions etnogràfiques realitzades a São Tomé i Príncipe. 
El capítol 4 (La Cooperació) suposa un acostament a la història i l'evolució de la cooperació i a alguns conceptes que s'hi relacionen, la qual cosa aclarirà les possibilitats d'actuació relacionades amb aquest àmbit que s'identifiquen en l'actualitat. Per tal de completar aquesta visió amb altres temàtiques relacionades amb la tesi, també es revisa la relació de la traducció i el cinema amb la cooperació i el desenvolupament.

El capítol 5 (São Tomé i Príncipe) està dedicat a São Tomé i Príncipe. És necessari dedicar un capítol a explicar el context del país que ha motivat $i$ al qual se situa aquesta investigació. En aquesta part de la tesi, per tant, es tracta la història del país, la seua situació lingüística, l'estat del sistema educatiu i algunes de les necessitats de cooperació més destacables.

El capítol 6 (Metodologia) presenta la metodologia emprada en aquesta investigació que, tot i que beu de disciplines diferents, s'ha servit de les tècniques d'investigació etnogràfiques per a desenvolupar el treball. $A$ més d'explicar en què consisteixen aquest tipus de tècniques que s'han utilitzat, també es dedica un espai per a presentar les persones participants, els instruments que s'han utilitzat, el mètode d'anàlisi de dades i la temporització de la investigació portada a terme.

Al capítol 7 (Resultats) s'exposen els resultats obtinguts dividits segons els participants: persones ancianes de São Tomé i Príncipe, persones no ancianes de São Tomé i Príncipe, experts en $\mathrm{Cl}$, experts en TAV i experts en cooperació lingüística. Aquest capítol serveix únicament per a donar a conéixer els fruits de la investigació.

El capítol 8 (Conclusions) es dedica a analitzar els resultats obtinguts i a extraure conclusions. En aquest 
cas, la distribució de les conclusions s'organitza segons temàtiques que es repeteixen a les intervencions dels participants $i$ que es relacionen entre sí. Com a colofó, es presenta una proposta d'iniciativa basada en l'anàlisi dels resultats que pretén posar en pràctica la intervenció de la TAV com a ferramenta d'integració d'ancians i de revitalització del forro a São Tomé i Príncipe. Per a finalitzar, es dedica un apartat a la consecució d'objectius i la validació d'hipòtesis, per a acabar dedicant un espai a les futures línies de recerca.

A més d'aquest contingut, la tesi inclou dos apartats per a la bibliografia i la filmografia consultada, així com una sèrie d'annexos electrònics que contenen el vídeo final de les entrevistes als participants ancians, les transcripcions del vídeo inicial de les entrevistes als ancians, les transcripcions de les entrevistes als participants no ancians, les transcripcions de les entrevistes i les grups de discussió amb els participants experts i les frases que es van utilitzar per a incitar el debat $i$ les reflexions d'aquests experts.

Per últim, cal assenyalar que, tot i que no es pot considerar que el format d'aquesta tesi és completament accessible, en la fase de maquetació sí que s'han tingut en compte alguns paràmetres d'accessibilitat per a persones amb ceguesa, dependents d'un sintetitzador de veu, o per a persones amb dificultats de visió per tal de facilitar-los la lectura. 


\section{LES LLENGÜES}

Cada llengua és una expressió irreemplaçable de l'experiència humana al món i la seua extinció significa la pèrdua irrecuperable de sabers culturals, històrics i ecològics únics (UNESCO, 2003). En aquest capítol s'expliquen alguns aspectes de les llengües que tenen relació amb aquesta tesi $\mathrm{i}$ que ajuden a emmarcar la temàtica que es proposa: els conceptes de pidgin, crioll i llengua indígena, que resulten imprescindibles per a comprendre l'evolució del forro a São Tomé i Príncipe (v. 5); la sociolingüística, que ajuda a explicar el context que es planteja en aquesta investigació; la posició de la UNESCO en la qüestió lingüística com a referent institucional; i en què consisteix la planificació lingüística i la revitalització d'una llengua, per a poder tindre una visió més àmplia del que suposaria aplicar la proposta d'aquesta tesi.

\subsection{CONCEPTES LINGÜÍSTICS}

Per la seua relació amb aquesta tesi, cal aclarir alguns termes sobre les llengües que es troben al cas concret de São Tomé i Príncipe per a comprendre més clarament el context històric, lingüístic i social del país (v. 5). En aquest cas, es tracta de conéixer alguns tipus de llengües o varietats lingüístiques, la seua definició i de quina manera es relacionen amb aquest treball:

Pídgins: un pidgin és una varietat lingüística que es crea a partir de diverses llengües en contacte en contextos multilingües d'urgència comunicativa per a possibilitar la 
interacció entre grups de parlants de llengües diferents (Bakker, 1995; García León, 2014; Hlibowicka-Weglarz, 2016; Medina, 2002). El que distingeix els pídgins d'altres llengües és que es formen molt ràpidament en condicions socials i històriques de contacte molt concretes, com ara els desplaçaments massius de persones - per exemple l'arribada d'africans a Amèrica entre els segles XVI i XIX-, o en situacions d'immigració (García León, 2014); no s'utilitzen com a llengua materna ni són la llengua habitual de comunicació de cap comunitat; i tenen un lèxic i una morfologia molt reduïts i simples adaptats de la llengua dominant (Bakker, 1995; García León, 2014; HlibowickaWeglarz, 2016; Medina, 2002). Per aquest motiu, un pidgin no pot actuar com a llengua natural, ja que li falten recursos per a verbalitzar moltes informacions. De fet, sol acompanyar-se d'altres formes de llenguatge, com el gestual (Hlibowicka-Weglarz, 2016). No obstant això, un pidgin pot convertir-se en una llengua criolla si es converteix en llengua materna, que compleix més funcions comunicatives i compta amb un lèxic molt més variat (García León, 2014). És el cas, per exemple, del forro, que va estar precedit per un pidgin, com s'explica en l'apartat 5.2 .

Criolls: la formació d'un crioll (com el forro) implica l'adquisició de parlants natius i, a més a més, la seua utilització no es veu limitada a contextos concrets com ocorre amb els pídgins, sinó que s'utilitza en una àmplia gama de situacions tant domèstiques com laborals, familiars, comercials, culturals, etc. (Medina, 2002). Per exemplificar la creació d'una llengua criolla, García León (2014, p. 53) explica el procés lingüístic que va ocórrer durant la colonització: 
En este contexto existían lenguas-modelo de los patronos colonos que no podían ser fácilmente aprendidas debido a la separación social que existía entre esclavos o trabajadores y los colonizadores; además, tampoco era posible aprender ninguna de las lenguas de la población subordinada por estar todas en situación de inferioridad, entonces, el grupo en contacto recurrió a la formación de un vernáculo criollo.

No obstant això, no tots els criolls es van crear a les plantacions colonials. Alguns van emergir als forts de la costa d'Àfrica Occidental des d'on els europeus van desplegar les seues activitats comercials, per la necessitat de comunicació entre africans i entre africans i europeus; uns altres, a les comunitats aîllades en què vivien els esclaus que s'escapaven de les plantacions (Arends, 1995).

Llengües indígenes: són les llengües dels pobles originaris d'un país o regió (United Nations, 2019). És a dir, una llengua que ha sigut desenvolupada durant mil-lennis per una comunitat concreta segons les seues necessitats culturals, comunicatives i de relació amb el medi ambient en què viuen. Quan una llengua indígena està en perill, els seus parlants també ho estan, ja que la seua llengua és fonamental per a la conservació de la seua cultura, expressió, idees, concepcions i identitat (United Nations, 2019). Aquest fenomen és extrapolable als criolls en risc de desaparició, com el forro, com es desprén de les entrevistes realitzades a São Tomé per a aquesta investigació (v. 7.1 i 7.2). De fet, a les comunitats amb 
llengües en vies de desaparició, les persones senten una pèrdua del sentit d'identitat (Hinton et al., 2018).

Tenint aquests conceptes en ment per la seua presència a la història de São Tomé i Príncipe, convé aprofundir en la relació que les llengües i les varietats lingüístiques tenen a les societats on es parlen i quines actituds lingüístiques prenen els seus parlants. L'apartat següent se centra en aquests aspectes, que pertanyen al camp d'estudi de la sociolingüística.

\subsection{SOCIOLINGÜÍSTICA}

Com s'ha esmentat anteriorment, la sociolingüística és la ciència que estudia la relació que existeix entre les llengües i la societat, així com les variacions lingüístiques que s'utilitzen per a expressar i reflectir factors socials com l'edat, el sexe, l'origen ètnic, la classe social o el tipus d'educació rebuda pels interlocutors, etc. (Centro Virtual Cervantes, 1997-2020; Holmes i Wilson, 2017). Com es desprén d'aquesta definició, la sociolingüística és una disciplina pròxima a la dialectologia, la sociologia del llenguatge o l'etnografia de la comunicació entre d'altres, però allò que la diferencia és que s'ocupa de definir els contextos lingüístics i socials que expliquen les variacions lingüístiques i d'analitzar les actituds dels usuaris respecte a aquests, mentre que la resta de disciplines s'interessen més pels aspectes socials 0 discursius de les llengües (Gimeno i Montoya, 1989).

Encara que l'origen de la sociolingüística se situa als Estats Units i el Canadà durant els anys seixanta amb els congressos realitzats a la Universitat de Califòrnia i a la Universitat d'Indiana sobre aquest tema (Gimeno i Montoya, 1989), cal tindre en 
compte que cada país té unes escoles, unes tradicions, unes convencions d'estudi i unes situacions sociolingüístiques particulars que determinen les investigacions que s'hi realitzen (Centro Virtual Cervantes, 1997-2020) i poden desembocar en concepcions diferents de certs aspectes de la sociolingüística. En qualsevol cas, dins la sociolingüística se situen alguns conceptes que es relacionen de manera directa amb aquesta tesi i s'emmarquen en un context de llengües en contacte: el bilingüisme, el multilingüisme, el plurilingüisme i la diglòssia. Aquests fenòmens originen certes actituds lingüístiques a les societats, com ara la ideologia lingüística, que s'explica més endavant. Abans, però, convé concretar el significat dels quatre conceptes bàsics que s'han esmentat anteriorment:

- $\quad$ Bilingüisme: l'ús de dues llengües per part d'un parlant o d'una comunitat (Medina, 2002).

- Multilingüisme: el coneixement o la coexistència de diverses llengües en una societat (Moreno García, 2010).

- $\quad$ Plurilingüisme: les varietats lingüístiques utilitzades per un mateix parlant, incloent-hi la llengua materna (L1) i les llengües posteriorment adquirides (L2, L3, etc.) (Moreno García, 2010).

- Diglòssia: aquesta situació es produeix en societats on es parlen dues llengües que s'utilitzen en contextos diferents. Mentre que una s'utilitza com a llengua de prestigi (religió, educació, etc.), l'altra s'utilitza de manera més informal i normalment per a la comunicació oral (Fishman, 1967).

A les societats on es donen aquests escenaris de contacte, és comú que una de les llengües en 
convivència siga utilitzada per un major número de persones, mentre que l'altra (o altres) és minoritària i de vegades minoritzada. És el que ocorre, per exemple, a São Tomé i Príncipe, on els criolls s'han vist en detriment, és a dir, són llengües minoritàries i també minoritzades, i és el portuguès la llengua que s'utilitza com a llengua oficial i de prestigi (v. 5.2). Per a diferenciar el significat d'aquests dos termes tan semblants, a Fundéu (2011) s'explica:

Con el término lengua minoritaria se hace referencia a la que tiene un número reducido de hablantes en relación con otra lengua en un territorio determinado; lengua minorizada, en cambio, es aquella cuyo uso está restringido por motivos políticos o sociales; aunque en una lengua puedan darse ambas condiciones, los términos no son sinónimos.

La present tesi pren com a referència aquesta definició i, per tant, sempre que es faça referència a una llengua que ha estat restringida es denominarà llengua minoritzada (encara que aquesta també siga minoritària).

Un altre fenomen que cal tindre en compte és la ideologia lingüística, és a dir, el conjunt de creences sobre una llengua que desenvolupen els seus parlants per a justificar-ne o racionalitzar-ne les estructures i l'ús (Silverstein, 1979), i que es transmeten des de la infantesa per part de familiars, professors, cuidadors, mitjans de comunicació, etc. (Bouchard, 2017).

Les ideologies lingüístiques creen sentiments (positius o negatius) envers les llengües i els seus parlants en relació amb aspectes com la seua utilitat, el prestigi, la facilitat o la dificultat de la llengua en qüestió o l'estatus 
(Pinto, 2018). Irvine i Gal (2000, pp. 37-39) identifiquen tres processos: iconization, fractal recursivity i erasure. Segons aquestes autores, iconization és la relació existent entre les llengües i les imatges socials amb què es relacionen. Un exemple seria l'estatus d'inferioritat que van prendre les llengües indígenes de les zones colonitzades per europeus per la idea que van transmetre els colons sobre el nivell cultural i de prestigi de la seua llengua respecte a la dels natius. Fractal recursivity és el procés pel qual les diferències que s'utilitzen a la fase d'iconization es projecten en un altre nivell. Per exemple, quan a la mateixa llengua de prestigi es considera més correcta la varietat dialectal de les zones urbanes que la de les zones rurals. Per últim, erasure suposa la invisibilització d'algunes persones, activitats o fenòmens sociolingüístics. Andronis (2004, p. 265) dona com a exemple l'opinió d'una persona sobre el quítxua i els seus parlants: "Ya no hay indios. No tienen cultura... ni hablan Quichua. Son campesinos, no más».

Com explica Andronis (2004), aquesta opinió desprèn un grau tan gran de marginació del quítxua i els seus parlants, que fins i tot nega la seua existència. A més, Swiggers (2019, p. 14) perfila cinc característiques de la ideologia lingüística:

1. És un fenomen de percepció afectiva i subjectiva que, encara que existeix a escala col-lectiva, no sempre està completament compartit dins d'una comunitat.

2. S'acompanya d'un intent de racionalització de les percepcions, encara que no pot justificar-se de manera lògica. 
3. Suposa una diferenciació entre llengües (o varietats/registres) i grups, i un context cultural o polític de diferenciació.

4. Sempre està relacionada amb relacions de poder o prestigi.

5. Implica una certa manipulació de dades, d'idees o de persones, i s'acompanya de processos de promoció, de repressió o de marginació.

En definitiva, la sociolingüística abraça una àmplia varietat de processos $i$ conceptes que relacionen les llengües i les societats on s'utilitzen, molts dels quals queden fora de l'abast d'aquesta tesi. No obstant això, totes les característiques que s'expliquen en aquest apartat es relacionen directament amb la investigació que es presenta i, per tant, resulten imprescindibles per comprendre el context al qual s'emmarca. São Tomé i Príncipe és un país multilingüe i existeix una diglòssia molt acusada que situa el portuguès molt per damunt dels criolls i una ideologia lingüística en la línia del que Irvine i Gal (2000) denominen com a iconization, ja que els criolls s'identifiquen com a llengües de menys prestigi, de zones rurals, indicatives d'un baix nivell cultural, i més pròpies de les persones ancianes (v. 5.2).

\subsection{LA UNESCO I LES LLENGÜES MINORITZADES}

La UNESCO promou la diversitat de cultures des de la creació de la seua Constitució, l'any 1945 (UNESCO, 2019c). En base a aquest principi, la UNESCO treballa en favor del plurilingüisme i la igualtat lingüística mitjançant tècniques interdisciplinàries que impliquen diversos sectors: la lingüística, 
l'educació, les ciències socials, etc. Un d'aquests productes va ser el Libro Rojo de las Lenguas Amenazadas, que pretenia recollir informació sobre les llengües en perill, reforçar les investigacions i la compilació de materials relatius a aquest tema, fomentar la publicació de materials i estudis sobre llengües en perill, etc. (UNESCO, 2003).

L'any 1997, es va organitzar la UNESCO Intergovernmental Conference on Language Policies in Africa (ICLPA) a Harare, Zimbabwe ${ }^{1}$, al qual van participar 51 de 54 països africans (entre ells, São Tomé i Príncipe). Aquesta conferència pretenia establir un pla de treball per definir nous rols per a les llengües minoritzades que es parlen als països participants i establir uns objectius i un temps per aconseguir-ho (UNESCO, 2006). Encara que es tractara d'un esdeveniment principalment lingüístic, els objectius marcats es van proposar amb la visió d'obtenir uns resultats que garantiren la democràcia dels ciutadans $i$ les ciutadanes d'aquests països (UNESCO, 2006, p. 74):

1. La participació activa de tots els ciutadans i les ciutadanes en totes les institucions socials, econòmiques, polítiques, etc.

2. Valorar culturalment l'estil de vida de cada país dins d'un context de justícia i igualtat, respectar els seus drets lingüístics i els drets humans, sense excloure les minories.

1 Amb la collaboració de I'OAU (Organization of African Unity) i I'ACCT (Agence de Cooperation Culturelle et Technique) (Agency for the FrenchSpeaking Community). 
3. Reconéixer la pluralitat etnolingüística dels països i acceptar-la com una forma de vida i un recurs ric per al desenvolupament i el progrés.

4. Promoure la coexistència pacífica entre les persones.

5. Crear unes polítiques lingüístiques que responguen al context plural africà que puguen posar-se en pràctica de forma eficient tant regionalment com internacionalment.

6. Promoure i preservar la identitat africana, així com fomentar-ne una visió orgullosa i segura.

7. Aconseguir que l'àmbit científic i tecnològic també siga accessible en les llengües nacionals de cada país.

D'acord amb aquestes aspiracions inicials, a la conferència es va dissenyar un pla d'acció que implicava els països participants, la UNESCO i les organitzacions col-laboradores $\mathrm{i}$ que tenia uns objectius concrets dels quals s'esperaven uns resultats que permeteren aconseguir els aspectes democràtics plantejats inicialment, com es pot veure a la il/lustració 1 (UNESCO, 2006): 
II-lustració 1. Pla d'Acció de l'ICLPA (UNESCO, 2006, p. 78)

\section{PLAN OF ACTION}

The Plan proposes actions at the regional, sub-regional and national levels. It states the nature of each action as well as its objectives, targeted results, time frame and implementing bodies.

\begin{tabular}{|c|c|c|c|c|c|}
\hline $\mathbf{N}$ & ACTIVITY & OBJECTIVE & RESULT TARGETED & TIME FRAME & IMPLEMENTING BODIES \\
\hline 1 & $\begin{array}{l}\text { Defining language } \\
\text { policies }\end{array}$ & Rehabilitating national languages & $\begin{array}{l}\text { A precise, consistent language policy for each } \\
\text { country (status, function) }\end{array}$ & $\begin{array}{l}\text { Short term (1998- } \\
\text { 1999) }\end{array}$ & Each state \\
\hline 2 & $\begin{array}{l}\text { Language management } \\
\text { plan }\end{array}$ & $\begin{array}{l}\text { Implementation of the language } \\
\text { policy }\end{array}$ & $\begin{array}{l}\text { Typology and use of national languages in the } \\
\text { various spheres of activities (politics, } \\
\text { administration, education, literacy) }\end{array}$ & $\begin{array}{l}\text { Short and medium } \\
\text { term }(1998-2000)\end{array}$ & Each country \\
\hline 3 & $\begin{array}{l}\text { Setting up national } \\
\text { structures }\end{array}$ & $\begin{array}{l}\text { Creation and revitalization of } \\
\text { operational policy and technical } \\
\text { structures for the implementation } \\
\text { and direction of the Action Plan }\end{array}$ & $\begin{array}{l}\text { The existence of functional structures (political, } \\
\text { technical, pedagogical, etc.) }\end{array}$ & $\begin{array}{l}\text { Short and medium } \\
\text { term }(1998-2000)\end{array}$ & All countries \\
\hline 4 & Language Atlas of Africa & Typology of African languages & $\begin{array}{l}\text { An exhaustive inventory of all African } \\
\text { languages and language areas }\end{array}$ & $\begin{array}{l}\text { Medium term (2000- } \\
2002)\end{array}$ & $\begin{array}{l}\text { UNESCO, OAU, ACCT, other } \\
\text { partners }\end{array}$ \\
\hline 5 & 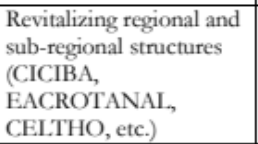 & $\begin{array}{l}\text { Effective involvement in the } \\
\text { promotion of African languages }\end{array}$ & $\begin{array}{l}\text { Rehabilitation of national and transnational } \\
\text { languages }\end{array}$ & $\begin{array}{l}\text { Medium and long } \\
\text { term } \\
(1999-2010)\end{array}$ & $\begin{array}{l}\text { Regional and sub-regional institutions } \\
\text { and partners }\end{array}$ \\
\hline 6 & $\begin{array}{l}\text { Producing linguistic and } \\
\text { didactic tools }\end{array}$ & $\begin{array}{l}\text { Intensive production of linguistic } \\
\text { tools and didactic material }\end{array}$ & $\begin{array}{l}\text { The promotion of a reading environment in } \\
\text { local, sub-regional and regional languages }\end{array}$ & $\begin{array}{l}\text { Short, medium and } \\
\text { long term }\end{array}$ & $\begin{array}{l}\text { Countries, regional and sub-regional } \\
\text { organizations, UNESCO and partners }\end{array}$ \\
\hline 7 & $\begin{array}{l}\text { Teaching of local, sub- } \\
\text { regional and regional } \\
\text { languages }\end{array}$ & $\begin{array}{l}\text { Using these languages as media of } \\
\text { instruction and teaching them }\end{array}$ & $\begin{array}{l}\text { The mastery of knowledge and know-how, and } \\
\text { the development of skills and identity [through } \\
\text { these languages] by the actors involved in } \\
\text { language reform and the target groups [...] }\end{array}$ & $\begin{array}{l}\text { Medium and long } \\
\text { term }\end{array}$ & IDEM \\
\hline 8 & Literacy & $\begin{array}{l}\text { The conduct of extensive literacy } \\
\text { campaigns }\end{array}$ & $\begin{array}{l}\text { Populations educated (in reading, writing, } \\
\text { arithmetic, in the various African languages) }\end{array}$ & $\begin{array}{l}\text { Medium and long } \\
\text { term }\end{array}$ & $\begin{array}{l}\text { Countries, sub-regional and regional } \\
\text { organizations, UNESCO, the OAU } \\
\text { and other partners }\end{array}$ \\
\hline 9 & $\begin{array}{l}\text { Regional and sub- } \\
\text { regional co-operation } \\
\text { congress of the Pan- } \\
\text { African Association of } \\
\text { Linguistics }\end{array}$ & $\begin{array}{l}\text { The promotion of national and } \\
\text { transnational languages as tools for } \\
\text { inter-African co-operation; } \\
\text { Create a pan-African association }\end{array}$ & $\begin{array}{l}\text { The promotion of dynamic networks for } \\
\text { multisectoral co-operation through } \\
\text { transnational languages; } \\
\text { Contribute individually and collectively to the } \\
\text { promotion of African languages }\end{array}$ & $\begin{array}{l}\text { Medium and long } \\
\text { term; } \\
\text { Short term }\end{array}$ & $\begin{array}{l}\text { Countries, sub-regional and regional } \\
\text { organisations, UNESCO, the OAU } \\
\text { and other partners } \\
\text { The OAU, UNESCO and ACCT }\end{array}$ \\
\hline 10 & $\begin{array}{l}\text { Follow-up and } \\
\text { evaluation }\end{array}$ & $\begin{array}{l}\text { Ensuring proper co-ordination of } \\
\text { the activities and measuring their } \\
\text { impact }\end{array}$ & $\begin{array}{l}\text { Implementation of the language management } \\
\text { plan and Action Plan }\end{array}$ & Biennial & $\begin{array}{l}\text { Countries, sub-regional and regional } \\
\text { organizations, UNESCO, the OAU } \\
\text { and other partners }\end{array}$ \\
\hline
\end{tabular}

Dissortadament, i tot i les expectatives que va generar la celebració d'aquesta conferència, no s'han implementat moltes de les accions que s'assenyalaven a l'ICLPA, especialment pel que fa a la creació, la implementació, les estratègies i la planificació de polítiques lingüístiques (el cas particular de les llengües a São Tomé i Príncipe s'explica en l'apartat 5.2). Sobre aquesta qüestió, a l'informe de la conferència es reflecteix l'opinió d'alguns acadèmics durant una comunicació personal (UNESCO, 2006, p. 12):

[...] the real enemy of African language is actually located within the African political structure(s), rather than in the external forces of 
domination (i.e., the West and its hegemonic languages). At the core of the discussion is therefore the question: Is linguistic indigenization possible at all in the absence of a democratic system?

[...] Where Democratization has been tried, eliteclosure takes over and imposes exoglossic forms.

Més enllà de la decepció pels resultats reals de I'ICLPA, aquesta primera conferència a Harare ha donat pas a altres conferències i contribucions importants en contextos més específics, com la conferència d'Asmara de l'any 2000 que, a més d'insistir en les demandes i les recomanacions de l'ICLPA, va ressaltar la importància d'una literatura africana i de la traducció i la cultura de llegir en llengües africanes (UNESCO, 2006).

La UNESCO, però, ha seguit pronunciant-se sobre la igualtat lingüística. L'any 2001 es va adoptar la Declaració Universal de la Diversitat Cultural, que reconeix una relació entre la diversitat biològica, la diversitat cultural i la diversitat lingüística, i que compta amb un pla d'acció (UNESCO, 2003, p. 3) al qual es recomana als Estats membre prendre mesures amb l'objectiu de:

1. Mantenir la diversitat lingüística i donar suport a l'expressió, la creació i la difusió del major número possible de llengües.

2. Fomentar la diversitat lingüística a tots els nivells d'educació sempre que siga possible i afavorir l'aprenentatge de diverses llengües des de la primera infància. 
3. Incorporar, quan pertoque, les pedagogies tradicionals al procés educatiu per tal de preservar i utilitzar plenament els mètodes de comunicació i transmissió dels sabers que estiguen millor adaptats a la cultura local i, quan la comunitat de parlants ho permeta, estimular l'accés universal a la informació de domini públic.

L'any 2002, es va publicar a l'International Journal on Multicultural Societies (IJMS) un número sobre la protecció de llengües minoritàries en perill, al qual participen diversos experts que contribueixen amb els seus coneixements sobre diferents aspectes de les minories lingüístiques (UNESCO, 2002). En aquesta publicació, Romaine (2002) parla de la falta de compromís real dels Estats amb la protecció de les llengües i recomana que es multipliquen els esforços per focalitzar les accions que es prenen perquè, diu, la conservació d'una llengua està vinculada amb la preservació del grup que la parla, la seua cultura i el seu hàbitat. En les seues paraules (p. 210):

\begin{abstract}
Although survival cannot depend on legislation as its main support, legal provisions may allow speakers of endangered languages to claim some public space for their languages and cultures from which we can all benefit.
\end{abstract}

L'any 2003, la UNESCO va celebrar a París la Reunió Internacional d'Experts sobre el programa de la UNESCO Salvaguardia de las lenguas en peligro, de la qual va sorgir l'informe Vitalidad y peligro de desaparición de las lenguas, que remarcava la necessitat d'unir esforços dels especialistes en llengües, les comunitats de parla, les ONG i les organitzacions governamentals $i$ institucionals per treballar de forma efectiva en favor de la diversitat lingüística (UNESCO, 2003). També s'hi fa èmfasi en la falta de 
recursos i formació que pateixen les persones que treballen per desenvolupar programes d'educació en una llengua minoritzada (p. 17):

A nivel de las comunidades locales y a lo largo de las últimas décadas, por ejemplo, ha habido muchas personas trabajando para desarrollar programas de educación lingüística, generalmente con recursos técnicos muy limitados. A diferencia de los docentes de las grandes lenguas del mundo, carecen no sólo de adiestramiento formal en la enseñanza de idiomas -que ahora es exigido por muchos gobiernos locales para tener la certificación de docente-, sino también de programas de estudio y, lo que es aún más crucial, de descripciones de la lengua básicas y utilizables.

En aquest informe, també es ressalta la responsabilitat dels lingüistes, els activistes i els responsables polítics de compilar i divulgar mecanismes més efectius i viables per sostenir i revitalitzar les llengües amenaçades però, sobretot, de treballar en col-laboració amb les comunitats amb una llengua en perill (UNESCO, 2003). Aquesta declaració suposa una justificació més per a pensar en nous mètodes per a revitalitzar llengües minoritzades i millorar així la vida dels seus parlants, com proposa aquesta tesi.

A més, aquest informe també inclou un apartat amb propostes per a evitar la pèrdua de llengües al món: facilitar la formació lingüística i pedagògica bàsica en aquestes llengües, desenvolupar iniciatives d'alfabetització i de capacitats locals de documentació, crear i aplicar una política lingüística 
nacional i una política educativa, millorar les condicions de vida i el respecte als drets humans de les comunitats de parla, etc. Un altre aspecte interessant que aporta aquesta publicació és la proposta d'una sèrie de factors que poden servir per a avaluar la vitalitat i l'estat de perill d'una llengua, que al mateix temps poden servir per a calibrar les actituds cap a les llengües i la urgència del treball de documentació, tot i que s'assenyala que no existeix un únic factor que puga servir per a avaluar aquests elements $\mathrm{i}$ es recomana examinar els factors de vitalitat en funció del propòsit de l'avaluació (UNESCO, 2003).

Entre les factors que es proposen de forma orientativa i que han d'adaptar-se al context local i a l'objectiu específic del projecte, es troben (UNESCO, 2003, pp. 15-16):

- La transmissió intergeneracional de la llengua.

- $\quad$ El número absolut de parlants.

- $\quad$ La proporció de parlants en el conjunt de la població, els canvis als àmbits d'ús de la llengua.

- $\quad$ La utilització de la llengua als nous àmbits (mitjans de comunicació, internet, etc.).

- La disponibilitat de material per a l'aprenentatge i l'ensenyament de la llengua.

Les actituds polítiques envers les llengües, les actituds dels membres de la comunitat cap a la seua llengua.

- $\quad$ El tipus i la qualitat de la documentació disponible sobre aquesta llengua. 
La proposta d'aquesta tesi, per exemple, suposaria l'aplicació de molts d'aquests factors, com la transmissió intergeneracional del forro, la utilització de la llengua als nous àmbits, i crear material per a l'aprenentatge i l'ensenyament d'aquesta llengua a través de la subtitulació.

Una de les declaracions més directes de la UNESCO en favor de la preservació lingüística és la declaració de l'any 2019 com l'Any Internacional de les Llengües Indígenes . L'objectiu d'aquesta iniciativa és sensibilitzar sobre el perill que corren aquestes llengües i reivindicar la importància que tenen com a vehicles de la cultura i les formes de vida dels seus parlants. Durant l'any 2019 s'han celebrat diferents esdeveniments com conferències, concerts, teatre, projeccions de pel-lícules, trobades, etc. arreu del món per a cuidar les llengües indígenes, cosa que en molts casos també implica millorar les condicions de vida dels seus parlants (UNESCO, 2019a; United Nations, 2018). Aquesta observació reforça la motivació principal de la present tesi, segons la qual, treballar en favor del forro pot millorar la percepció que es té de les persones ancianes $\mathrm{i}$, en conseqüència, milloraria també les seues condicions de vida.

Per últim, amb l'objectiu de continuar amb el treball de l'Any Internacional de les Llengües Indígenes i d'impulsar aliances i accions més ambicioses per evitar la desaparició de les llengües indígenes, l'Assemblea General de les Nacions Unides va proclamar el període de 2022-2032 com a la Dècada Internacional de les Llengües Indígenes. Serà necessari esperar dos anys per a conéixer quines seran les propostes i el pla d'acció concrets per a complir els objectius durant el decenni (Naciones Unidas México, 2019; UNESCO, 2020), però més enllà de les conclusions que puguen sorgir com a resultat, convé pensar en noves línies d'actuació i permetre que des de diferents àmbits de coneixements 
puguen aportar-se idees de protecció i revitalització lingüística, com la que es presenta amb aquest treball.

\subsection{PlanificACIÓ LINGÜÍSTICA}

La planificació lingüística podria definir-se com el conjunt de tècniques que es realitzen de forma organitzada per intentar influir en el comportament de les persones respecte a l'estructura, l'adquisició o l'extensió d'una llengua amb l'objectiu de resoldre problemes lingüístics (Appel i Verhoeven, 1995; Cooper, 1989). Aquestes tècniques poden incloure l'avaluació de recursos disponibles per a realitzar la planificació, assignar funcions diferents per a cada llengua o varietat lingüística dins d'una comunitat, etc. (Wardhaugh, 2010).

Appel i Verhoeven (1995) expliquen que les estratègies de desenvolupament d'un país exigeixen una anàlisi adequada sobre quins són els recursos socials i culturals amb què compta i les possibilitats que ofereixen i, dins d'aquesta agenda, la planificació lingüística és una qüestió de gran importància, ja que les llengües no només són instruments de comunicació, relacions comercials i desenvolupament educatiu; també són marques d'identitat i un distintiu cultural. En paraules de Cooper (1989, p. 182):

[...] language planning is such a complex activity [...], fundamentally because it is a tool in the service of so many different latent goals such as economic modernization, national integration, national liberation, imperial hegemony, racial, 
sexual, and economic equality, the maintenance of elites, and their replacement by new elites.

Dins de la complexitat que suposa desenvolupar una planificació lingüística, McCarty (2018) explica quines són les tres activitats principals a partir de les quals es construeix el procés de planificació:

1. Status planning: aquesta primera activitat respon a la pregunta de «per a què s'utilitzarà la llengua?», és a dir, cal decidir quina llengua s'impulsarà als mitjans de comunicació, els jutjats, les escoles, etc.

2. Corpus planning: suposa el desenvolupament de sistemes d'escriptura, gramàtiques, vocabulari nou, materials d'ensenyament, etc.

3. Acquisition planning: significa la preparació de programes educatius. Cal plantejar-se qui adquirirà la llengua i com ho farà.

Encara que allò ideal al cas de São Tomé i Príncipe seria que les mesures de planificació lingüística les portara a terme l'Estat, les iniciatives que proposen la revitalització dels criolls, com la que es planteja en aquest treball, podrien servir de base per a futures accions administratives en aquesta línia i podria formar part del corpus planning o de l'acquisition planning. El contingut subtitulat dels vídeos podria plantejar-se com a material pedagògic, per exemple, i marcar una metodologia lúdica i alternativa.

Per a comprendre millor la planificació lingüística, Cooper (1989) proposa quatre aspectes: 
1. Gestió de la innovació. Els canvis del comportament lingüístic, estiguen planificats o no, són producte de la difusió. Per exemple, quan un escriptor adopta una innovació lingüística que han adoptat i utilitzat altres escriptors o usuaris abans. Com s'explica en l'apartat 5.2, quan es va colonitzar São Tomé i Príncipe la llengua de difusions comunicatives i culturals era el portuguès $i$, per tant, va ser aquesta la llengua d'influència.

2. Màrqueting. Com ocorre a les tècniques comercials de màrqueting, els planificadors lingüístics han de reconéixer, identificar o dissenyar productes que el possible consumidor trobe atractius. Segons Cooper (1989), quan una acadèmia de la llengua prepara una llista de termes nous i convé que els planificadors sàpiguen quines característiques d'aquests termes augmentarien les seues probabilitats d'acceptació pels usuaris. Al cas de São Tomé i Príncipe, no ha hagut interès institucional per fomentar les llengües criolles $\mathrm{i}$, per tant, tampoc no s'ha realitzat cap tipus de màrqueting (v. 5.2).

\section{L'instrument per a l'adquisició i el manteniment} del poder. La planificació lingüística tracta d'influir en el comportament de les persones a l'hora d'utilitzar unes llengües o varietats. Cooper (1989) posa com a exemple quan a Etiòpia es va realitzar una planificació lingüística d'alfabetització i els governants van triar alfabetitzar en llengües vernacles. D'aquesta manera van ser els primers beneficiats, ja que van aconseguir neutralitzar l'amenaça d'oposició estudiantil. A São Tomé i Príncipe, la llengua associada al poder i a la cultura era el portuguès i aquesta tendència s'ha mantingut (v. 5.2). 
4. Presa de decisions. És necessari plantejar-se qui adopta quines innovacions, per què, com, en quines condicions i amb quins efectes ho fa. Des de la perspectiva històrica de São Tomé i Príncipe, han sigut les classes socials més acomodades qui han optat pel portuguès en tots els contextos i, les persones de les zones rurals, considerades d'una classe social inferior, qui parlaven els criolls. La decisió d'abandonar els criolls per part d'aquest segon grup, per exemple, buscava l'efecte d'accedir a una educació o un nivell social superior (v. 5.2).

A banda d'aquestes observacions de McCarty (2018) i Cooper (1989), per a Moreno- Fernández (2005), hi ha dues formes de planificar: el desenvolupament lingüístic i la determinació lingüística. El desenvolupament lingüístic s'aplica quan es pretén millorar l'estat d'una llengua però ja hi ha una varietat que funciona com a llengua nacional (com seria el cas de São Tomé i Príncipe). La determinació lingüística, en canvi, s'aplica a situacions que requereixen crear o recrear una varietat lingüística (MorenoFernández, 2005). Aquest va ser el cas de l'hebreu, per exemple, amb el qual es van portar a terme certes estratègies de planificació lingüística per a millorar el seu estat i convertir-lo en la llengua oficial d'Israel amb molt bons resultats (Liddicoat i Bryant, 2001; Zuckerman i Walsh, 2011). L'hebreu com a llengua materna estava extint i només s'utilitzava com a llengua litúrgica. La planificació per a revitalitzar-lo i convertir-lo en llengua nativa va començar l'any 1879 de la mà de Ben-Yehudah que, a més de publicar diversos articles en defensa de la revitalització de l'hebreu, un diccionari i periòdics en aquesta llengua, va començar a utilitzar-la amb els seus amics i la seua família i va animar altres jueus a fer el mateix. La llengua estava revitalitzada uns 30 anys abans que es constituira l'Estat d'Israel. A partir d'aquest moment, es va produir un ampli moviment d'estandardització de la llengua amb la creació del Comité 
per a la Llengua Hebrea, la fundació de la Universitat Hebrea de Jerusalem i el treball de l'Acadèmia de la Llengua Hebrea. Israel necessitava tindre una llengua nacional i des del Govern es van fer esforços de planificació per consolidar l'hebreu. La política lingüística impulsada pel Ministeri d'Educació ha sigut exitosa quant al procés d'aculturació dels immigrants i d'estandardització i ensenyament de I'hebreu modern (Abramac, 2015; Muñoz Solla, 1998; SáenzBadillos, 1998).

El cas de l'hebreu és molt peculiar (Muñoz Solla, 1998), ja que comptava amb un context històric únic. En qualsevol cas, la demanda de drets lingüístics és comuna a totes les minories amb llengua pròpia (Wardhaugh, 2010). Els estats que vulguen establir la justícia social (v. 4.2.3) al seu territori, també han de comptar, com indica Abarrategi (2016), amb les minories lingüístiques. Una planificació que busque desenvolupar llengües minoritàries o determinar llengües extintes (com s'ha vist al cas de I'hebreu), se servirà de tècniques de revitalització lingüística, com s'explica a l'apartat següent.

\subsubsection{Revitalització lingüística}

La revitalització forma part de la planificació lingüística $\mathrm{i}$ té com a objectiu mantenir $\mathrm{i}$ augmentar la presència d'una llengua en perill de desaparició a les comunitats on tradicionalment es parla (Hinton et al., 2018).

Quan una llengua entra en vies de desaparició, ho pot fer per dos motius principals: per una desaparició sobtada dels seus parlants a causa d'alguna malaltia o d'algun tipus de genocidi; o bé per una raó molt més habitual com és la falta de transmissió generacional de la llengua en qüestió dins el si familiar en pro d'una llengua majoritària (Ascencio, 2009; Ferguson, 2006; UNESCO, 2003). Abans que la llengua desaparega totalment, però, 
ja es troba en un estat obsolescent en què el seu ús queda reduït a l'àmbit privat. Aquest procés sol anar acompanyat d'un préstec de vocabulari de la llengua dominant i de la simplificació i la reducció de la gramàtica i la fonologia en la llengua pròpia (Ferguson, 2006). Als casos de les comunitats aïllades que es veuen implicades en processos d'urbanització i d'industrialització (la qual cosa implica un major contacte amb una comunitat lingüística més nombrosa $i$ poderosa) prompte s'implanta la concepció que la llengua dominant és la llengua més necessària d'aprendre i, llavors, la minoritària comença a considerar-se retardada i s'associa amb una pèrdua d'oportunitats, amb les persones ancianes, amb l'àmbit rural, etc., no sol incloure's als contextos públics com les escoles (Ascencio, 2009; Ferguson, 2006) i es converteix, per tant, en una llengua minoritzada (v. 1.2). La llengua de l'educació és essencial, ja que la situació s'agreuja encara més quan l'alfabetització en la llengua minoritzada és limitada (Ferguson, 2006).

Els prejudicis contra les llengües minoritzades també són un factor decisiu al seu procés de desaparició perquè, com explica Ascencio (2009), si bé les actituds positives cap a una llengua no són un factor determinant per a mantindre-la, les actituds negatives sí que són motiu suficient per a fer que els seus parlants canvien el seu comportament lingüístic en favor d'una altra llengua. És precisament l'encoratjament d'ús de la llengua allò que inhibeix la tendència a la discriminació i l'opressió que pateixen els parlants d'aquestes minories lingüístiques i redirigeix la situació cap a l'emancipació i l'apoderament (Hornberger, 2005). Per a establir un sistema efectiu de revitalització lingüística que ho puga permetre, és necessari el suport econòmic i polític, tant de les comunitats locals com dels Governs nacionals (UNESCO, 2003). Havent arribat a aquest punt, la qüestió és si hi ha motius perquè un Govern invertisca recursos, temps i diners en aquesta activitat. 
Per a Zuckerman et al. (2014) hi ha tres motius fonamentals. En primer lloc, per estètica, ja que les llengües tenen formes diferents d'expressar idees distintes i aquesta informació ens indica com és una cultura, de manera similar a les obres d'art, que ens parlen dels seus autors i que conservem amb cura i interès als museus. En segon lloc, perquè és ètic. La majoria de llengües que desapareixen, no ho fan per elles mateixes, sinó com a resultat d'una situació d'opressió prolongada, com expliquen Ascencio (2009) i Ferguson (2006). Zuckerman et al. (2014) entenen, per tant, que la revitalització lingüística també pot ser una forma de rescabalar aquestes comunitats. Per últim, la revitalització d'una llengua és útil, perquè beneficia els seus parlants en augmentar la seua autoestima, el seu orgull cultural, la consciència de comunitat i del seu entorn; també ofereix els avantatges cognitius del plurilingüisme front al monolingüisme (Chibaka, 2018; Marian i Shook, 2012; Zuckerman et al., 2014); i fins i tot pot reportar beneficis econòmics al país en cas que s'estimule el turisme cultural, com és el cas d'Austràlia (Zuckerman et al., 2014), que aprofita la cultura indígena per a oferir opcions de turisme cultural com ara, visites a assentaments aborígens o experiències relacionades amb l'art i les representacions aborígens (Mahadevan, 2017).

Per al cas particular d'Austràlia i els seus aborígens, Zuckerman et al. (2014) proposen una compensació ex gratia als aborígens australians per part de l'Estat per desagreujarlos pel tractament que se'ls ha donat en el passat. Aquests autors proposen la creació del que anomenen Native Tongue Title, que reconeixeria els drets dels indígenes i comportaria un ajut econòmic perquè pogueren utilitzar i revitalitzar les seues llengües de la manera que consideren pertinent.

A més, hi ha estudis que relacionen les llengües de les comunitats indígenes amb el seu estat de salut o fins 
i tot amb l'ecologia. Whalen et al. (2016), per exemple, defensen que els programes lingüístics a les comunitats natives americanes poden millorar la salut mental i física dels participants, independentment de la seua edat. Altres autors relacionen el coneixement de les llengües indígenes amb una menor taxa de suïcidis entre joves (Hallet et al., 2007), menys trastorns mentals i patiment emocional (GómezRestrepo et al., 2016), i fins i tot una menor taxa de diabetis (Oster et al., 2014).

Pel que fa a la relació entre les llengües, les comunitats indígenes i el medi ambient, LaPier (2018, s/p) diu:

Language loss can be considered as extreme as the extinction of a plant or an animal. Once a language is gone, the traditional knowledge it carries also gets erased from society.

Aquesta autora explica que, a Hawaii, per exemple, un grup de científics treballa amb lingüistes hawaians per saber més coses sobre un tipus de caragol en perill d'extinció. El motiu d'aquesta col-laboració és que en les creences tradicionals hawaianes, els caragols dels arbres es consideren part del «regne dels déus» i es veneraven, protegint-los així de la sobreexplotació (LaPier, 2018). Degawan (2019, s/p) dona un altre exemple de la relació que hi ha entre les llengües i el medi ambient dels seus parlants:

Los inuits, por ejemplo, tienen unos cincuenta términos para describir la nieve en sus diferentes estados. Al ser esta su principal elemento natural, los nativos han adquirido un conocimiento profundo de ella. Lo mismo ocurre con los igorotes de la cordillera en Filipinas 
cuando hablan del arroz, desde que es solo una semilla hasta que las espigas están maduras para la cosecha, pasando por el aspecto de los granos recién cocidos y listos para el consumo, $y$ el alcohol que se obtiene de ellos.

Per a Abarrategi (2016), les estratègies per a garantir la gestió sostenible del medi ambient poden desenvoluparse amb estratègies de revitalització lingüística perquè les llengües contenen informació que han acumulat durant els segles sobre els equilibris ecològics i cuidar la salut de la llengua significa cuidar el valor del medi ambient.

La diversitat lingüística ha servit a la humanitat per a créixer $\mathrm{i}$ enriquir-se culturalment $\mathrm{i}$ el seu declini hauria de ser motiu de preocupació. La revitalització lingüística es percep a les comunitats de parla com una activitat sanadora, justa i d'apoderament i sovint suposa també una revitalització de tradicions culturals, protocols de comportament i formes de relacionar-se amb la família, els amics i altres membres de la comunitat, restablint així una relació amb la terra i els espais, les plantes, els animals i les diferents formes de relacionar-s'hi (Hinton et al., 2018).

\subsubsection{Un exemple de revitalització lingüística: el nàhuatl d'EI Salvador}

El mètode per a desenvolupar una planificació lingüística i revitalitzar llengües ha de dissenyar-se individualment per a cada país i adaptar-se a la seua realitat perquè puga funcionar, ja que són conceptes que no poden separar-se del context històric i social de les comunitats (Cooper, 1989). No obstant això, des del punt de vista d'aquesta tesi, resulta especialment 
interessant el projecte de revitalització del nàhuatl (El Salvador) pel paper que prenen les persones ancianes al procés, els beneficis socials que comporta i pel limitat suport econòmic i institucional amb què va començar.

La llengua nàhuatl és l'última sobrevivent de les llengües indígenes que antigament es parlaven a El Salvador (Ascencio, 2009). A l'inici d'aquest projecte, el nàhuatl comptava només amb uns 200 parlants, tots ells ancians, i s'havia deixat de transmetre a les noves generacions (Ascencio, 2009; Lemus, 2008). L'alumnat de les escoles que van començar a participar en aquest experiment de revitalització ha arribat a tindre un nivell bàsic alt de la llengua amb només d'una a tres hores de classe setmanals en acabar l'etapa educativa. El reforç venia de la mà de les persones ancianes, a qui se'ls va atorgar el paper de tutors i consultors de nàhuatl. D'aquesta manera, els xiquets podien practicar la llengua en situacions reals amb les persones ancianes de la comunitat (Lemus, 2008), la qual cosa coincideix amb el primer principi de la sociodidàctica de llengües de Dolz (2019), que determina que la dinàmica de pràctiques lingüístiques contribueixen a l'aprenentatge en l'escola i en altres contextos.

El programa de formació a mestres en llengua nàhuatl, interculturalitat i metodologia per a l'ensenyament d'idiomes va començar amb uns seminaris patrocinats per la Universidad Don Bosco, que consten de 20 hores d'aprenentatge de la llengua nàhuatl i d'altres 20 hores d'aprenentatge d'aspectes metodològics. Amb el pas del temps, l'aprenentatge de nàhuatl es va dividir en dos grups: principiants i avançats. Cada grup quedava al càrrec d'un professor avançat de nàhuatl i un consultor nahuatlparlant (Lemus, 2015). Aquest aspecte també es pot enllaçar amb un altre principi de Dolz (2019), el sisé, segons el qual les 
habilitats del professorat són fonamentals per tal d'assegurar l'aprenentatge escolar.

L'any 2009 es va crear una diplomatura en Educació Intercultural Bilingüe i Llengua Nàhuatl per a mestres del sistema educatiu públic que va tindre una gran acollida. A l'inici del projecte, el Ministeri d'Educació d'El Salvador no va mostrar cap interès per la revitalització del nàhuatl, però a partir de l'èxit de la certificació d'aquesta diplomatura sí que va començar a donar suport als professors i a acceptar l'ensenyament de nàhuatl a les escoles públiques participants, tot i que la llengua encara s'ensenya al temps residual de les altres classes perquè, per ara, no forma part del currículum nacional. A més, durant l'any escolar la Universidad Don Bosco ha començat a donar suport a l'organització de diversos tallers dirigits a mestres de nàhuatl de les escoles participants amb l'objectiu de reunir els mestres per a intercanviar experiències, aclarir conceptes, recollir propostes de temes per als tallers següents, compartir problemes i solucions, i mantenir una formació constant en llengua i cultura nàhuatl. Els materials utilitzats en aquests tallers han estat dissenyats específicament per al projecte, com ara llibres de text, recursos audiovisuals, etc. També es compta amb convidats del món acadèmic que contribueixen amb els seus coneixements a l'ensenyament, la cultura, la revitalització lingüística i la revalorització cultural indígena. No obstant això, els professors de nàhuatl són professors i aprenents alhora; per això estan en constant formació. Els tallers són una ajuda, però l'objectiu és que cada professor es faça responsable del seu propi aprenentatge a partir de les ferramentes bàsiques i el suport lingüístic i metodològic que els ofereix la Universitat (Lemus, 2015). De nou, es pot identificar un altre principi de Dolz (2019), segons el qual les limitacions institucionals en la política lingüística i els projectes lingüístics de les escoles permeten o limiten l'oportunitat d'ensenyar (quart principi). 
Quan els mestres ja han rebut la formació bàsica, poden iniciar el programa d'ensenyament de nàhuatl a les seues escoles. Han de negociar amb el director de l'escola on treballen i amb la resta de professors per a fer les classes en hores residuals d'altres assignatures, ja que el currículum escolar d'El Salvador és molt rígid i no contempla un espai per a activitats extracurriculars. Des que el Ministeri dona suport al projecte, però, el programa s'ha institucionalitzat en algunes escoles i açò facilita que se li assigne un horari. Cal tindre en compte que els professors que participen al projecte són voluntaris i col-laboren perquè senten un interès personal en l'estudi, la promoció i la conservació del nàhuatl i les manifestacions culturals que s'hi associen. No reben cap compensació econòmica per impartir classes de nàhuatl ni pels materials didàctics que utilitzen (Lemus, 2015).

L'any 2012 es va realitzar una avaluació del programa a les escoles participants: es va entrevistar el professorat, la direcció dels centres, l'estudiantat, i les famílies. També es van gravar algunes classes per observar com era el desenvolupament en la pràctica. Les conclusions d'aquesta avaluació indiquen una recepció positiva del projecte per part de l'alumnat i les famílies i que l'aprenentatge del nàhuatl es realitza de forma contínua a totes les escoles participants. L'any 2015 ja hi havia més de 60 docents diplomats i més de 100 capacitats als seminaris lingüístics i metodològics per a continuar amb aquesta activitat (Lemus, 2015; Soriano, 2015).

Paral-lelament, hi ha un projecte d'immersió lingüística per a infants de tres a cinc anys d'ascendència indígena anomenat Cuna Náhuat, una escoleta on s'utilitza el nàhuatl com a llengua d'instrucció i interacció. A la Cuna Náhuat se segueixen els programes oficials per a l'educació infantil d'El Salvador, però integrat en un ambient lingüístic que fa que els xiquets i les xiquetes 
utilitzen el nàhuatl per a comunicar-se. L'ús de l'espanyol no està prohibit i, de fet, és la llengua que prefereixen els infants per a comunicar-se entre ells, però les cuidadores sempre responen en nàhuatl i aquesta és la llengua $a m b$ què acaben comunicant-se amb elles. Les famílies informen que els fills utilitzen el nàhuatl a casa en algunes situacions quotidianes $\mathrm{i}$, per aquest motiu, també han sol-licitat classes de nàhuatl, ja que volien començar a utilitzar-lo també en l'àmbit domèstic (Boitel, 2018; Lemus, 2015).

Des del seu inici l'any 2010, la Cuna Náhuat ha comptat amb el suport del Ministeri d'Educació (fins a l'any 2014), la Universidad Don Bosco, UNICEF, l'Alcaldía Municipal de Santo Domingo de Guzmán, la Unidad de Salud i unes altres entitats que han col-laborat en accions específiques dins del centre. Encara que no sempre s'ha pogut obrir tots els mesos lectius de l'any per falta de finançament, aquest projecte ha aconseguit canviar la percepció que es tenia del nàhuatl. Ja no és una llengua sense valor ni ús pràctic, sinó que té un valor econòmic i, sobretot, funcions educatives i comunicatives, encara que per ara siguen limitades. Però més enllà de la revitalització del nàhuatl, la Cuna Náhuat ha comportat beneficis socials, com la transformació de la imatge de la dona indígena, que ha passat de ser una ciutadana de tercera categoria a ser una figura respectada i admirada per la comunitat. Les cuidadores de la Cuna Náhuat han demostrat que poden canviar els paradigmes existents sobre el rol de la dona indígena i ara són mestres, participen en actes públics, són convidades especials en esdeveniments públics i privats, les entrevisten als mitjans de comunicació, etc. (Lemus, 2015).

Com s'ha vist al llarg d'aquest capítol, les llengües minoritzades tenen un gran pes al sentit d'identitat, l'apoderament i les formes de relacionar-se de les persones que les parlen. Les llengües indígenes, a més, estan relacionades amb 
l'ecologia i, de vegades, també amb la salut dels seus parlants. De fet, la Declaració Universal de la Diversitat Cultural per part de la UNESCO reconeix la relació existent entre la diversitat biològica, la diversitat cultural i la diversitat lingüística. I encara es poden trobar més motius per a vetlar per la revitalització d'aquestes llengües, com ara els motius estètics, ètics i d'utilitat que citen Zuckerman et al. (2014) (v. 1.4.1). Aquesta tesi planteja la subtitulació de vídeos de persones ancianes com a mètode de cooperació per a treballar transversalment per la revitalització del crioll forro i per la integració de les persones ancianes, fent valdre els seus coneixements lingüístics, culturals, ecològics i tradicionals. És a dir, seria una activitat d'apoderament per als ancians participants i pretendria millorar la forma en què la societat es relaciona amb ells. La postura que pren la UNESCO envers les llengües minoritàries i l'exemple de la revitalització del nàhuatl d'El Salvador, desenvolupada amb un baix pressupost i la implicació de diferents membres de les comunitats amb resultats positius, donen força a la proposta que presenta aquesta tesi per a aconseguir millorar la situació de les persones ancianes i del crioll forro a São Tomé i Príncipe. 


\section{LA TRADUCCIÓ AUDIOVISUAL: LA SUBTITULACIÓ}

La TAV és un element clau en la concepció d'aquest treball, ja que constitueix el principal objecte d'estudi en investigar-la com a eina de cooperació i també el mitjà a través del qual s'ha accedit als participants de São Tomé i Príncipe. Consisteix en l'adaptació a una altra llengua d'un text audiovisual, és a dir, d'un text dinàmic amb un missatge que es pot transmetre de forma acústica o visual, i que pot ser tant verbal com no verbal (Bartoll, 2015). La particularitat d'aquesta modalitat de traducció és que el traductor ha d'aconseguir crear uns diàlegs en la llengua meta havent d'ajustar-se a les limitacions temporals i espacials que imposen les imatges (Chaume, 2013). També cal assenyalar que el material audiovisual pot presentar-se tant en diferents suports (televisió, DVD, cine, etc.) com en diferents formats (AVI, MPEG, etc.) (Ramírez, 2015).

Per tal de portar a terme aquest tipus de traducció, s'hi apliquen les següents modalitats segons la classificació de Bartoll (2015):

- $\quad$ Audiodescripció: està pensada per a persones invidents i consisteix en la narració en directe o prèviament enregistrada de les imatges que aporten informació rellevant en qualsevol text audiovisual.

Doblatge: en aquesta modalitat, les veus originals del text audiovisual se substitueixen per les veus d'actors i d'actrius de doblatge. 
- Interpretació consecutiva: es tracta d'una traducció oral que es realitza després del text oral original. Dins d'un mitjà audiovisual, la interpretació consecutiva pot utilitzar-se en entrevistes, informatius, taules redones, conferències, teatre i rarament en pel-lícules.

Interpretació simultània: sol utilitzar-se més que la interpretació consecutiva. El que diferencia una modalitat de l'altra és que la interpretació simultània ofereix una traducció oral immediata del text original. S'utilitza en ràdio, televisió, festivals de cinema i actes en directe com conferències, congressos i teatre.

- Intertitulació: és la traducció del text escrit entre escenes que apareix al cine mut (intertítol). Aquesta traducció pot realitzar-se substituint els intertítols en llengua original pels intertítols en llengua meta, però també mitjançant altres modalitats, com ara, la subtitulació o la traducció oral de l'intertítol (audiointertitulació).

- $\quad$ Remake: en aquesta tècnica es torna a realitzar el text audiovisual, tant acústicament com visual, en la llengua meta.

Resum escrit: es tracta d'un text breu que explica l'acció de la pel·lícula, obra de teatre o òpera.

- $\quad$ Subtitulació: permet mantindre el text audiovisual de partida mentre es mostra la traducció escrita en pantalla, sincronitzada amb els elements orals originals.

Veus superposades o voiceover: és una tècnica en la qual la gravació de la traducció es reprodueix sobre les veus del text original. 
Entre les diferents modalitats de TAV, resulta especialment adient per a aquesta investigació la subtitulació per diversos motius, com ara, que es tracta d'una modalitat econòmica, relativament senzilla de portar a terme i d'eficàcia provada en l'aprenentatge de llengües (v. 2.3). Així i tot, els paràmetres habituals de la subtitulació s'han d'adaptar a la realitat cultural de São Tomé i Príncipe i modificar-se per a facilitar la lectura i la comprensió dels subtítols, com s'explica en l'apartat 6.5.

A l'hora de traduir contingut per al cinema o la televisió, els Estats solen inclinar-se per la subtitulació o pel doblatge, tot i que alguns com Bulgària, Bèlgica i Canadà utilitzen ambdues opcions (Chaume, 2012) i d'altres, com Polònia i Rússia es descanten per modalitats menys comunes, com les veus superposades (Talaván, 2013). En general, i encara que la situació està canviant els últims anys per les noves plataformes audiovisuals com veurem més endavant, se subtitula a Croàcia, Dinamarca, Finlàndia, Grècia, Holanda, Islàndia, Noruega, Portugal, Romania, Suècia i Xipre (Bartoll, 2015; Talaván, 2013), Estats Units, Oceania i a la major part del continent africà (Chaume, 2012), mentre que al nord d'Àfrica, els països àrabs, la majoria de països d'Amèrica Llatina (Chaume, 2012), Alemanya, Hongria, Itàlia, Espanya, República Txeca, Eslovàquia, Turquia, Ucraïna, França i Àustria, s'utilitza més el doblatge (Bartoll, 2015; Talaván, 2013).

L'elecció d'una modalitat o una altra a l'hora de traduir depén generalment de motius econòmics, històrics o polítics. Si tenim en compte que els països que tradicionalment han fet ús del doblatge compten amb una indústria molt sòlida, que dona treball a milers de persones, queda clar que el factor econòmic resulta de gran importància per decantar-se per aquesta opció en lloc de per la subtitulació, que no requereix la contractació de tant de personal. A més, als països que històricament han optat pel 
doblatge, el públic ja s'ha acostumat a consumir material doblat i, per tant, no té les destreses visuals adequades per llegir subtítols sense molèsties (Talaván, 2013). Pel que fa als factors polítics, caldria assenyalar que alguns Governs dictatorials de l'Europa del segle XX (com Espanya) van fer ús del doblatge com a forma de censura (Díaz-Cintas, 2001; Talaván, 2013).

Ara bé, és evident que les noves plataformes audiovisuals com Netflix o HBO, que ofereixen contingut audiovisual a milions d'usuaris, han repercutit tant en la indústria cinematogràfica i televisiva com en els professionals involucrats al procés i en els hàbits dels consumidors (del Pino i Aguado, 2012). Les pràctiques per evitar distribucions il-legals per internet i el desig de fidelitzar usuaris a les noves plataformes fan que el temps per a realitzar les traduccions siga cada vegada menor, ja que les dates d'estrena ara són pràcticament simultànies arreu del món (Orrego, 2013). És el cas, per exemple, de la popular sèrie Game of Thrones (Juego de Tronos, HBO, 2011-2019). El primer capítol es va estrenar el 17 d'abril de 2011 als Estats Units i a Canadà (Hibberd, 2011; Game of Thrones, HBO'S Sweeping New Fantasy Series, Begins April 17 on HBO Canada, 2011) i a Espanya el 9 de maig del mateix any (Ruiz de Elvira, 2011). La sèrie va tindre una gran acollida des d'un principi (Ruiz de Elvira, 2011; TV by the numbers, 2012) i, a partir de l'any 2012, es van disparar les descàrregues il-legals dels capítols de les noves temporades (Ernesto, 2014, 2016 i 2017; Gartenberg, 2019; Jarvey, 2015; Kain, 2012; Kamen, 2015; Williams, 2014). Per intentar fer front a aquest problema, a partir de 2015 la sèrie es va començar a retransmetre de manera simultània en 170 països (Gómez, 2015) fins el seu últim episodi (8a temporada) emés el 19 de maig de 2019 arreu del món (Justo, 2019).

Tot i això, com assenyala Talaván (2013), durant els últims anys s'ha observat en països com Espanya un 
major interès per la subtitulació per diversos factors. Un d'ells és que hi ha més presència de la subtitulació a la televisió en forma de subtítols per a persones sordes (SPS). A més a més, com indica Gómez (2015), la necessitat o desig d'aprendre llengües estrangeres i la disponibilitat de clips i vídeos en versió original subtitulada a internet, entre d'altres raons, fan que molts joves es decidisquen per aquesta opció. En aquest cas, poden decantar-se per accedir a les noves plataformes audiovisuals disponibles o pel material subtitulat per aficionats (fansub).

Es consideren fansub els subtítols de contingut audiovisual que encara no està disponible en la llengua meta realitzats a casa per aficionats. Els seguidors d'aquest contingut, ja siguen pel-lícules o sèries, descarreguen el guió i utilitzen programes d'edició lliures per a crear els subtítols (Chaume 2013). A Espanya, per exemple, que es tracta d'un país amb tradició dobladora, es fa ús d'aquesta classe de subtitulació no-professional per tal d'accedir més ràpidament al contingut audiovisual traduït (Orrego, 2013). Les característiques del fansub, a més, són més flexibles que les de la subtitulació professional (Garrido Abellán, 2014; Ferrer Simó, 2005), com ara, per exemple, el temps que està el subtítol en pantalla, un aspecte que, com s'explica en l'apartat 6.5, és necessari modificar en el context de São Tomé i Príncipe.

El ventall de possibilitats que ofereixen les diferents modalitats de TAV és molt ampli. Com hem vist, la subtitulació es distingeix de la resta de modalitats perquè permet mantindre el text de partida mentre es mostra la traducció escrita en pantalla sincronitzada amb els elements orals originals (Bartoll, 2015). A continuació, s'expliquen el procés i les convencions bàsiques de la subtitulació a més d'analitzar, per la seua relació amb aquesta tesi, la subtitulació a l'Àfrica. 


\subsection{EL PROCÉS DE LA SUBTITULACIÓ}

Normalment, el procés professional s'origina amb l'encàrrec del client (estudi de cine, cadena de televisió, agència de publicitat, etc.) que demana la traducció a un estudi de subtitulació, que s'encarrega de buscar el traductor que la realitzarà (en cas de tindre la formació adequada, també pot realitzar la sincronització dels subtítols) i, una vegada finalitzada, el traductor l'entrega en el temps acordat $\mathrm{i}$ amb les convencions estilístiques $\mathrm{i}$ ortotipogràfiques que hagen sigut sol-licitades (Chaume, 2009).

Mentre que en el doblatge són necessaris la traducció i l'ajust d'un guió i la seua interpretació per actors sota la supervisió d'un director de doblatge i, de vegades, amb l'ajut d'un assessor lingüístic, en la subtitulació només intervenen els traductors, que tradueixen els diàlegs, i els tècnics encarregats de la localització (procés tècnic mitjançant el qual es dona el TCR, Time Code Reader), que serveix per a comptar el temps d'entrada i eixida dels subtítols en hores, minuts, segons i fotogrames, o en hores, minuts, segons i milisegons (Bartoll, 2015; Chaume, 2009; DíazCintas i Remael, 2007). En comparació, el procés de subtitulació és visiblement més senzill, ja que no hi ha tantes figures involucrades (Chaume, 2009). De fet, ni tan sols el software necessari per a subtitular resulta problemàtic, ja que hi ha diversos programes d'accés lliure disponibles a internet, gratuïts i d'ús molt intuïtiu, com ara el Subtitle Workshop, el Subtitle Edit o l'Aegisub entre d'altres (Chaume, 2009; Talaván, 2013), per als quals no es requereixen tècnics o professionals específics, ja que estan a l'abast de tothom. Aquests són els motius principals pels quals s'ha considerat la subtitulació com la modalitat més adient per aplicar al context de São Tomé i Príncipe, un país en vies de desenvolupament i amb recursos limitats (v. 5.3). 


\subsection{CONVENCIONS BÀSIQUES DE LA SUBTITULACIÓ}

La necessària integració dels elements orals, visuals i els subtítols, i l'adaptació d'aquests elements a les capacitats de lectura de l'espectador fan que siguen imprescindibles certes convencions establertes que han de tindre's en compte a l'hora de subtitular. Encara que aquestes convencions poden variar segons el país, en general la majoria solen implementar-se de la mateixa manera (Díaz-Cintas, 2012):

1. Consideracions espacials: els subtítols se situen en la part inferior de la pantalla excepte quan apareix informació visual imprescindible en aquesta zona; un subtítol no deu tindre més de dues línies; per a indicar que dos personatges parlen en un mateix subtítol, una de les línies es reserva per a cadascun dels personatges; en general, cada línia té entre 28 i 49 caràcters, el més freqüent és trobar 37 caràcters per línia; al còmput de caràcters, cada consonant o vocal compta un espai igual que cada signe ortogràfic, com les comes, les interrogacions i els espais entre paraules.

2. Consideracions temporals: els subtítols han d'entrar i eixir de pantalla en sincronia amb els diàlegs, encara que en ocasions es permet alguna asincronia i que els subtítols entren $o$ isquen uns fotogrames abans 0 després, com quan es treballa amb un gran cabal lèxic; els subtítols es deixen un mínim d'un segon i un màxim de sis segons en pantalla. En cps (caràcters per segon), que indiquen la velocitat del subtítol, Ferriol (2012) recomana entre 10 i $14 \mathrm{cps}$ ( $p$. 48), encara que alguns estudis recents, com els de González-Iglesias (2011) i Szarkowska 
i Gerber-Morón (2018) detecten una major capacitat dels espectadors per a llegir subtítols a més velocitat.

3. Consideracions ortotipogràfiques: per indicar que un subtítol s'ha acabat, s'utilitza el punt; no s'aconsella l'eliminació de signes de puntuació com exclamacions, interrogacions, etc.; s'utilitzen els punts suspensius per indicar pausa, omissió o interrupció en el discurs; la intervenció de dos personatges al mateix subtítol s'indica anteposant un guió al principi de la segona línia, que correspondria al segon personatge; les majúscules només s'utilitzen per traduir el títol del programa i per referir-se a un text que apareix escrit en la versió original, com ara, el titular d'un periòdic; la cursiva indica les veus que procedeixen d'un televisor, ràdio, títols de pel-lícules, llibres, lletres de cançons, paraules en un altre idioma, personatges que estan fora de pantalla i la veu d'un narrador en off; les cometes que més s'utilitzen són les dobles (") i no les angulars («») $i$ indiquen cites $i$ el valor de certes paraules o expressions com malnoms, préstecs 0 jocs de paraules.

4. Consideracions lingüístiques: és aconsellable fer ús d'abreviatures i símbols coneguts pels espectadors; els números s'escriuen de l'u al nou en lletres $\mathrm{i}$, a partir de deu, en dígits; no és necessari fer ús de tots els espais d'una línia abans de passar a la següent; és aconsellable que la segmentació del text, de línia a línia i de subtítol a subtítol, respecte les unitats de sentit per a facilitar la comprensió del missatge; és necessari sintetitzar la informació del text oral perquè l'espectador tinga temps de llegir els subtítols, però sense descuidar el to i el registre de l'original; han de respectar-se els matisos idiomàtics $i$ les referències 
culturals de l'original; han de subtitular-se tant els textos que apareixen a les imatges, per exemple pancartes 0 retalls de periòdics, com les cançons sempre que siguen rellevants per a la trama; els subtítols mai han de contradir allò que es veu a les imatges; els subtítols han d'estar el més sincronitzats possible amb els diàlegs de la pel-lícula.

\subsection{LA SUBTITULACIÓ EN L'APRENENTATGE DE LLENGÜES}

Durant els últims anys, s'ha investigat molt sobre l'aprenentatge de llengües estrangeres mitjançant els subtítols amb resultats molt positius, com ara els estudis realitzats per DíazCintas (2012), Marzà i Torralba (2014), Talaván (2011 i 2013) i Vanderplank (1988) sobre l'aprenentatge d'anglès o Lertola (2012) sobre l'aprenentatge d'italià.

Díaz-Cintas (2012), per exemple, assenyala cinc possibilitats de subtítols que ajuden els alumnes de forma diferent en l'aprenentatge d'una llengua estrangera:

1. Subtítols interlingüístics estàndard: la pista sonora està en la llengua que es vol aprendre i els subtítols en la llengua materna dels alumnes. Aquests subtítols reforcen la comprensió de diàlegs originals i permeten crear connexions entre dos sistemes lingüístics. Es recomanen per als principiants en l'estudi de la llengua estrangera (p. 99).

2. Subtítols interlingüístics inversos: la pista sonora està en la llengua materna i els subtítols en la llengua meta. Aquests ajuden a ampliar el lèxic, però no fomenten 
la comprensió auditiva, ja que no se sent la versió original (p. 100).

\section{Subtítols intralingüístics en la llengua materna:}

tant els subtítols com la pista sonora estan en la mateixa llengua (p. 100). Es tracta d'una opció beneficiosa per a millorar l'alfabetització (Gernsbacher, 2015; PlanetRead, 2018a; PlanetRead, 2018b).

\section{Subtítols intralingüístics en la Ilengua meta:} també se'ls coneix com a subtítols bimodals. Al contrari que en l'opció anterior, tant els subtítols com l'àudio estan en la llengua estrangera. Només servirien per a alumnes que ja tenen un bon coneixement de la llengua que estudien, però en aquests casos s'obtenen molt bons resultats tant en la comprensió oral i escrita com en l'ampliació de lèxic (DíazCintas, 2012, p. 101).

5. Subtítols bilingües: l'àudio està en un idioma i els subtítols en dues llengües distintes. Fins ara, no hi ha molts estudis sobre el valor pedagògic d'aquesta combinació ( $p$. 101).

Vanderplank (1988) va ser un dels primers a defensar el potencial de la subtitulació passiva, és a dir, aquella en què «el subjecte es limita a visionar material audiovisual subtitulat» (Torralba, 2016, p. 146), en l'aprenentatge incidental de llengües, ja que l'esmentat material proporciona molta informació real i comprensible. Segons Vanderplank (1988), els vídeos subtitulats ajuden l'alumnat a millorar el nivell de comprensió d'una llengua estrangera pel sistema dual que comporta la subtitulació (codis verbals i codis visuals), que permeten realitzar les connexions referencials necessàries per a la comprensió del vídeo. Més endavant, investigadors com Ellsworth (1992) i Rees (1993) van 
demostrar que els subtítols intralingüístics per a persones sordes eren una bona eina perquè l'estudiantat d'una llengua estrangera amb un nivell avançat amplie vocabulari, millore la comprensió oral i puga aprendre aspectes socioculturals, i Danan (2004) i d'Ydewalle i Pavakanun (1997), entre d'altres, que els subtítols interlingüístics són beneficiosos per a l'augment del lèxic d'una llengua estrangera, especialment quan l'alumnat es troba als nivells inicials d'aprenentatge.

Entre els beneficis d'utilitzar la subtitulació en les classes de llengua estrangera de secundària, Terrero (2016) assenyala que, en lloc de portar a l'aula recursos comunicatius dissenyats específicament per a l'ensenyament, permet exposar l'alumnat a situacions comunicatives reals. Segons aquesta autora, a causa de l'ajut que comporten els subtítols, l'alumnat se sent més motivat i pateix menys ansietat de participar en situacions comunicatives reals en la llengua estrangera. També troba que els subtítols són beneficiosos per a millorar diferents destreses a més de la comprensió oral, com ara la síntesi o l'escolta selectiva. Pel que fa al tipus de subtítol, Terrero (2016) pensa que s'ha de triar segons el nivell de l'alumnat $\mathrm{i}$ les destreses que es pretenguen millorar.

Marzà i Torralba (2014) avaluen la utilitat dels subtítols interlingüístics en l'aprenentatge d'una llengua estrangera al context d'un país amb tradició dobladora, com és el cas d'Espanya. Aquestes autores analitzen les actituds de 118 xiquets/es entre nou i dotze anys envers la subtitulació de dibuixos animats i obtenen resultats molt positius, tenint en compte que molts dels participants havien expressat certes dificultats 0 incomoditats per a llegir els subtítols i veure el vídeo alhora.

Lunin i Minaeva (2015) valoren la utilitat de l'ús de subtítols bilingües (en la llengua meta i la llengua original) en 
l'aprenentatge d'una llengua estrangera, ja que troben que ofereix a l'alumnat un major control sobre l'evolució del seu aprenentatge i els dona més confiança, a més de combatre l'avorriment i la frustració que de vegades genera en els alumnes l'aprenentatge d'un idioma. Segons aquests autors, la utilització de la subtitulació a la classe d'una llengua estrangera acosta la possibilitat d'aprendre un idioma a persones de tot el món, fins i tot aquelles que es troben fora del sistema educatiu, ja que només es necessitaria tindre accés a internet i un aparell electrònic per a reproduir el vídeo. També aprecien el fet que existeix una àmplia varietat de continguts audiovisuals, la qual cosa facilita trobar vídeos amb una temàtica que resulta interessant per a l'alumnat com també recomana Soler (2017).

Aquestes investigacions justifiquen l'ús de la subtitulació passiva en el camp de la revitalització lingüística tal i com es proposa en aquesta tesi, ja que s'ha demostrat la seua eficàcia per a millorar no només els coneixements lèxics i la comprensió oral, sinó també els coneixements sobre aspectes socioculturals associats al producte que s'emet (Lunin i Minaeva, 2015; Terrero, 2016), i també tenen bona recepció per part dels espectadors, fins i tot quan no estan habituats al material subtitulat, com ocorre a l'estudi de Marzà i Torralba (2014). No obstant això, els treballs esmentats se centren en un context occidental; és per això que, per al context específic d'aquesta tesi, resulten especialment interessants els estudis sobre els efectes de la subtitulació passiva a Camerun i Sud-àfrica realitzats per Ayonghe i Toikou (2015) i Kruger et al. (2007) respectivament, i que es desenvolupen amb més deteniment en l'apartat 2.4 .

A més de les investigacions al voltant de la subtitulació passiva, existeix un altre vessant que estudia la utilitat de la subtitulació activa en l'aprenentatge de llengües. És a dir, quan és 
l'alumnat qui subtitula per a millorar o aprendre noves destreses en la llengua estrangera que estudia. Segons Neves (2004), la diversió que suposa comptar amb un element nou com el material audiovisual dins l'aula de llengua estrangera fa que l'alumnat assimile millor els nous conceptes lingüístics i s'esforce per realitzar els subtítols correctament. Per a Talaván (2013) aquesta activitat és verdaderament completa i té un gran potencial educatiu, ja que, a més dels beneficis que assenyala Neves (2004), també suposa l'enriquiment del vocabulari i de la comprensió auditiva, l'estimulació de l'habilitat d'escriptura, la contextualització de la llengua i les conductes socials relatives a aquesta llengua, etc. (Díaz-Cintas, 2012).

Alguns projectes europeus estudien aquesta relació entre els subtítols i l'assimilació de llengües, entre altres aspectes. Un exemple d'aquests projectes és ClipFlair (2011-2014), finançat per la Comissió Europea i desenvolupat per un equip internacional (Clipflair, 2011; Ros, 2017). Aquesta proposta presenta una comunitat web que convida alumnes i professors a cooperar amb altres usuaris i participar en el procés d'ensenyamentaprenentatge mitjançant una aplicació de fàcil accés que permet l'aprenentatge de llengües estrangeres a través de la gravació de la veu dels alumnes, per exemple amb doblatge, audiodescripció, karaoke, etc. i la utilització de subtítols i anotacions (Clipflair, 2011). Aquesta aplicació estableix un marc metodològic per a l'aprenentatge mitjançant la interacció de so, el text oral i escrit i les imatges. També compta amb material educatiu per a practicar la lectura, la comprensió auditiva, l'expressió escrita i l'expressió oral sense oblidar-se'n del factor cultural (Clipflair, 2011; Ros, 2017).

A més de Clipflair o el seu antecessor Subtitles and Language Learning (Vertimo studiju katedros, 2010), també s'han desenvolupat altres projectes internacionals des de 
l'àmbit universitari per aplicar la subtitulació (entre altres modalitats) a l'aprenentatge de llengües, per exemple, PluriTAV (2017-2019), coordinat per la Universitat de València i finançat per l'Agencia Estatal de Investigación (AEI) i el Fons Europeu de Desenvolupament Regional (FEDER), que recorre a la TAV per a perfeccionar competències en les llengües pròpies i desenvolupar competències plurilingües amb la creació d'una web d'accés lliure i gratuïta amb recursos didàctics i fonamentació teòrica per a docents (PluriTAV, 2020) i proposa mètodes d'ús didàctic de la TAV per al desenvolupament de competències en llengües estrangeres amb experimentació a les aules (Cerezo et al., 2018).

Tot i la rellevància de la subtitulació activa per a l'aprenentatge de llengües, la present tesi opta per la subtitulació passiva per motius logístics. És cert que hi ha suficient disponibilitat de programari gratuït i senzill d'utilitzar, però la necessitat de comptar amb un ordinador i una connexió elèctrica estable és una dificultat difícil de sobrepassar a São Tomé i Príncipe. Per aquest motiu, aquesta investigació se centra en la possibilitat que la programació en forro subtitulada al portuguès resultaria beneficiosa per a la familiarització amb la llengua i per afavorir-ne un aprenentatge passiu. En aquest cas, sembla que les millors opcions serien els subtítols interlingüístics estàndard (àudio en forro i subtítols en portuguès) pels motius que es detallen a continuació.

En primer lloc, es considera que, a pesar de comptar amb un sistema d'escriptura oficial i certa tradició escrita en forro (Cardoso et al., 2015), aquesta no està suficientment estesa entre la població, com s'explica al capítol 5 , ja que les llengües criolles de São Tomé i Príncipe no s'inclouen al sistema d'ensenyament del país (Hagemeijer et al., 2018) i l'accés a llibres és realment limitat. Com veurem a l'apartat 5.2.1, el forro es relaciona amb la música, les històries, els proverbis, els acudits, les 
tradicions, etc. En conseqüència, tot i que compta amb una literatura pròpia, és una llengua lligada a la tradició oral.

En segon lloc, a causa de la situació que s'explica al paràgraf anterior, el coneixement general que es té de forro és prou més baix que el que es té de portuguès i, per tant, resultaria més senzill per a la majoria de la població llegir i assimilar uns subtítols en portuguès, que és la llengua en què actualment estan més habituats a llegir i escriure. Per aquest motiu, en aquest paral-lelisme s'equipara el forro al terme "llengua estrangera» que utilitza Díaz-Cintas (2012) en la descripció de les combinacions que proposa, encara que en la pràctica no ho siga.

\subsection{LA SUBTITULACIÓ A ÀFRICA}

Àfrica és un continent multilingüe i multiètnic (Alibbi, 2014). Segons Andriesen (2015), però, la traducció no es considera una disciplina molt rellevant en aquest territori, probablement perquè amb la quantitat de persones que hi viuen amb rendiments baixos, el fet d'estudiar llengües o traducció sembla un luxe. De fet, com explica aquest autor, pràcticament cap dels membres de KITA (Kenya Interpreters and Translators Association) són traductors a temps complet. Normalment tenen un altre treball, sovint completament diferent i allunyat de l'àmbit lingüístic. A més, molts d'ells tradueixen de l'anglès a altres llengües com el francès, l'alemany o el rus, fins i tot quan no són parlants natius, ja que es pensa que no hi ha diners per traduir a llengües indígenes com el swahili, el kamba o el kikuyu.

No obstant això, cada vegada hi ha més investigadors i investigadores que s'interessen per la TAV en el 
context africà i que es plantegen la idoneïtat i les possibles aplicacions de cada modalitat en països concrets. Un dels països que més tracten aquests nous estudis és Camerun, que compta amb 281 llengües indígenes (v. 1.1 per a una definició del terme) i dues llengües oficials: l'anglès i el francès (Ethnologue, 2019). A Camerun, molts canals de televisió i productores utilitzen diverses modalitats de TAV (doblatge, subtitulació i voiceover) al material audiovisual que emeten per abraçar totes les necessitats lingüístiques del país. Ayonghe i Ntowa (2015) sostenen que la TAV a Camerun no només ajuda l'audiència a comprendre millor la cultura i el contingut de la programació, sinó que també contribueix a l'aprenentatge de llengües (per exemple, els camerunesos que només parlen francès, poden aprendre anglès a través de la TAV). En relació amb aquesta última qüestió, Ayonghe i Tiokou (2015) van desenvolupar un estudi per analitzar l'impacte de la subtitulació a Camerun quant a l'alfabetització, el seu ús a la televisió i el paper que compleix al desenvolupament social amb resultats encoratjadors.

Es van triar 100 estudiants de la University of Buea, 45 homes i 55 dones d'entre 17 i 40 anys, que consumien programes de la televisió camerunesa subtitulats. Aquest grup d'estudiants es va dividir en dos grups segons la seua llengua materna (anglès o francès) i van respondre per escrit una enquesta sobre la seua percepció de la subtitulació a la televisió de Camerun. D'acord amb les respostes, Ayonghe i Tiokou (2015) conclouen que la subtitulació estimula la capacitat lingüística dels espectadors. De fet, 38 estudiants d'un grup i 31 de l'altre van assenyalar la millora en la comprensió de la L2 (llengua meta) gràcies a la subtitulació interlingüística. 18 estudiants van opinar que la subtitulació era útil en l'aprenentatge d'una llengua estrangera i també per millorar destreses relacionades amb la traducció. L'estudiantat també aprecia el paper de la subtitulació en l'augment de l'alfabetització en 
la línia de Fons (1999), és a dir, entenent per alfabetització no només llegir i escriure, sinó també la comprensió i l'expressió oral. Per últim, Ayongue i Tiokou (2015) assenyalen que, si el nivell d'alfabetització dels espectadors millora amb la programació subtitulada, el context lingüístic de Camerun facilitarà una millor adquisició i ús de les dues llengües oficials del país: l'anglès i el francès.

En aquesta mateixa línia de la subtitulació a la televisió africana, l'objectiu de l'estudi de Kruger et al. (2007) és comprovar si la introducció de subtítols en una llengua minoritzada contribuiria a la percepció d'un valor simbòlic i instrumental del multilingüisme a Sud-àfrica, la qual cosa seria beneficiosa per al desenvolupament de les llengües minoritàries, estendria la comprensió de la programació emesa en anglès i apoderaria les persones donat que es milloraria l'accés a la informació.

Segons Kruger et al. (2007), I'SABC, emissora nacional de Sud-àfrica que només subtitulava a l'anglès quan es va realitzar aquesta investigació, considera poc pràctic i massa car donar a totes les llengües de Sud-àfrica el mateix temps a les programacions. Tenint en compte aquest escenari, la proposta dels autors és provar que la subtitulació, una modalitat econòmica, pot fer molt per promoure el multilingüisme a la televisió. Per tal de validar la seua hipòtesi, els autors es van centrar en les llengües tshivenda $\mathrm{i}$ xitsonga, que es parlen majoritàriament en zones rurals per menys d'un $5 \%$ de la població.

Van participar un total de 62 persones dividides segons la seua llengua materna ${ }^{2}$. Dins d'aquests dos

\footnotetext{
${ }^{2}$ L'article no aporta informació sobre quines altres llengües parlaven o entenien els participants.
} 
grups, es van subdividir en tres grups. A cada subgrup se li va mostrar un episodi d'una sèrie multilingüe majoritàriament en anglès, però també en zulú i sesotho. A un grup se li va mostrar amb subtítols en anglès, a un altre sense subtítols i a l'altre, amb subtítols en la seua llengua materna (tshivenda o xitsonga). Els resultats quant a comprensió del contingut indiquen el següent:

Taula 1. Grup tshivenda. Estudi Kruger et al. (2007) GRUP TSHIVENDA: COMPRENSIÓ DEL CONTINGUT

Subgrup 1: subtítols en anglès

Taula 2. Grup xitsonga. Estudi Kruger et al. (2007)

\section{GRUP XITSONGA: COMPRENSIÓ DEL CONTINGUT}

Subgrup 1: subtítols en anglès

$29 \%$

Subgrup 2: subtítols en xitsonga

La informació d'aquesta part de la investigació no és massa clara, ja que els participants no eren suficients com per a proporcionar dades quantitatives vàlides; el vídeo contenia molta informació en anglès; els participants no podien llegir els subtítols a la velocitat necessària per a seguir l'argument; 
aproximadament el $25 \%$ dels participants eren analfabets i, per últim, la subtitulació no estava completament establerta a Sud-àfrica i, per tant, els participants no estaven familiaritzats amb aquesta modalitat (Kruger et al., 2007).

Sense oblidar tots aquests aspectes, es pot apreciar que la modalitat que genera una major comprensió entre els participants són els subtítols en anglès al grup thsivenda i els subtítols en xitsonga al grup xitsonga. Aquest estudi, però, proporciona més informació a més del percentatge de comprensió del contingut del vídeo. També es va realitzar un qüestionari per avaluar quina era l'actitud dels participants envers la llengua. En aquest qüestionari, el $77 \%$ dels participants va manifestar que gaudirien més la televisió si la seua llengua materna hi tinguera més presència; el $90 \%$ va respondre que li agradaria tindre periòdics en la seua llengua; al $85 \%$ li agradaria que la seua llengua materna s'estudiara en primària i secundària (Kruger et al., 2007).

Pel que fa al cinema, cal tindre en compte l'increment de produccions africanes, que no només es consumeixen al seu país d'origen, sinó que també s'exporten (Alibbi, 2014). Una de les indústries cinematogràfiques més reconegudes a Àfrica és la nigeriana, coneguda com a Nollywood (Alibbi, 2014; Evuleocha, 2008).

Nollywood és una empresa potent a Nigèria: el sector cinematogràfic és la segona font econòmica del país després de l'exportació de petroli i es caracteritza per parlar de Nigèria i d'Àfrica i per representar una gran varietat d'identitats que, fins ara, no havien tingut representació a nivell global. A més, és un camp de producció cultural excepcional, ja que també reflecteix fins a cert punt la situació lingüística del país: el 56\% de les pel-lícules es 
roden en llengües indígenes i el $44 \%$ en anglès (Fuentes Luque, 2017).

Per la naturalesa multilingüe de Nigèria, on es parlen 517 llengües vives (Ethnologue, 2019), la traducció és una necessitat i, en el cas de Nollywood, la subtitulació a l'anglès sembla ser la millor opció per facilitar el procés que, a més, ajuda els africans que parlen llengües indígenes i viuen en altres continents a tornar a connectar amb les seues arrels (Alibbi, 2014; Fuentes Luque, 2017). Cal assenyalar que de la subtitulació de pel-lícules de Nollywood s'encarreguen els directors, els productors i els distribuïdors (Fuentes Luque, 2017). És cert que s'ha de tindre en compte el baix pressupost amb què compten, però, com assenyala Fuentes Luque (2017) açò també es deu a la falta d'oferta formativa específica en traducció a la regió. A més, la presència de programari i ordinadors i el fàcil accés a la tecnologia i la programació necessària per a subtitular ha popularitzat aquesta modalitat a Nigèria i moltes de les pel-lícules d'aquest país estan subtitulades en anglès (Alibbi, 2014), tot i que el percentatge d'alfabetització del país és només del 60\% (Ethnologue, 2019; UNESCO, 2019b). Amb aquest context, els subtítols interlingüístics en anglès (llengua franca del país) resulten l'opció més útil si tenim en compte la quantitat de consumidors d'aquestes pel-lícules que hi ha en altres països africans (Alibbi, 2014).

La necessitat de subtitular ha crescut a mesura que el cinema ha guanyat públic d'altres països africans i s'opta pels subtítols monolingües en anglès per arribar a més espectadors d'altres parts del món, especialment quan es tracta de pel-lícules en llengües indígenes (Alibbi, 2014). És el cas de moltes de les pel.lícules nigerianes que es roden en igbo, hausa i yoruba, les llengües de tres dels grups ètnics més nombrosos del país: es televisen a DSTV, la televisió per cable amb major cobertura a 
Àfrica, que pertany a l'empresa sud-africana MultiChoice, i els subtítols en anglès ajuden aquells que no entenen aquestes llengües a poder seguir l'argument (Alibbi, 2014; DSTV, s/d).

Encara que es tractarà més específicament la utilització de les llengües criolles als mitjans de comunicació de São Tomé i Príncipe en l'apartat 5.3, cal assenyalar que un dels motius principals pel qual s'ha considerat la subtitulació una modalitat idònia per a treballar en aquest país és que es tracta d'una modalitat prou econòmica i açò permetria el seu ús en un país com aquest, amb una taxa elevada de pobresa i falta de recursos (Cooperación Española, 2006-2008; Gonçalves de Género, 2012; Instituto Nacional de Estatística, 2012; PNUD, 2002), com hem vist al cas de Nigèria i les seues produccions cinematogràfiques.

A més, pot trobar-se un cert paral-lelisme entre l'interès dels expatriats nigerians per mantindre el contacte amb les seues arrels a través de la subtitulació de pel-lícules en llengües indígenes (Alibbi, 2014; Fuentes Luque, 2017) i el que, segons Bouchard (2017), tenen els expatriats de São Tomé pel forro, com una forma de reafirmar la seua cultura d'origen.

Cal destacar també la importància de l'estudi de Kruger et al. (2007) en el plantejament del present treball, ja que la informació que es recull sobre la comprensió dels subtítols ha servit per recolzar la idea d'adaptar els paràmetres de subtitulació als hàbits de lectura dels participants no ancians per tal d'assegurar que puguen llegir i comprendre els subtítols correctament (v. 6.5); i també com a exemple per a la formulació d'algunes preguntes als entrevistats de São Tomé i Príncipe, com ara, aquelles que fan referència a la presència del forro als mitjans de comunicació i al sistema educatiu (v. 6.3.1.2). 


\section{L'ETNOGRAFIA}

La present tesi pren un vessant de caràcter etnogràfic a la metodologia desenvolupada a São Tomé i Príncipe, ja que s'empren tècniques pròpies d'aquest camp com es pot veure als apartats $3.1 \mathrm{i}$ 3.2. Per a poder comprendre aquest procediment $\mathrm{i}$ com i per què s'aplica en aquesta investigació, a continuació es defineixen certs aspectes relacionats amb l'etnografia, exemples d'altres investigacions etnogràfiques desenvolupades a São Tomé i Príncipe i la metodologia etnogràfica que es pot trobar en aquesta tesi.

\subsection{HISTÒRIA, CONCEPTES, I DEFINICIONS}

Per tal de tindre una visió completa del que significa l'etnografia i de quina manera es relaciona amb aquesta tesi, cal comprendre primer com es relaciona amb altres termes similars, com l'antropologia i l'etnologia.

L'antropologia és l'estudi de l'ésser humà i ha tingut diferents accepcions amb el pas dels anys, des de la perspectiva naturalista de Diderot que incloïa l'anatomia dins de l'antropologia, fins la perspectiva social i cultural de Lévi-Strauss, entre d'altres (Copains, 2012). Segons Copains (2012, p. 32) i Lombard (2012, p. 38), els termes antropologia i etnologia poden utilitzar-se hui dia com a sinònims, encara que l'elecció d'un o altre dependrà de les institucions, les circumstàncies o l'orientació metodològica de cada autor/a. 
Antigament, es considerava que l'etnologia estudiava les societats sense escriptura i no mecanitzades, a les quals es titllava pejorativament de primitives. Aquesta concepció, però, va canviar al llarg dels anys amb el desenvolupament de diferents estudis que van demostrar que les societats que abans es tenien per primitives, són en realitat complexes i organitzades. Aleshores, l'etnologia es va orientar a l'estudi de tota aquella cultura i societat diferent $i$, especialment, de les comunitats xicotetes en què l'especialització econòmica i professional no té tant de pes com les relacions interpersonals (Lombard, 2012).

D'acord amb la definició que dona l'Enciclopèdia Catalana, l'etnologia és la "ciència que estudia les ètnies, els pobles i llurs cultures», mentre que l'etnografia és la "ciència que descriu els costums i les tradicions dels pobles». Per tant, l'etnografia es defineix com l'estudi dels coneixements sobre realitats socials i culturals delimitades pel temps i per l'espai; una teoria de la descripció. L'etnologia, en canvi, es dedica a l'anàlisi comparativa de les cultures humanes (Rockwell, 2009).

Segons Copains (2012), la part descriptiva de l'etnologia és l'etnografia, i aquesta consisteix a l'anàlisi del comportament, les creences, els valors, etc. d'un grup d'individus mitjançant l'observació i la descripció (Nolla, 1997). Cerri (2012) explica que el concepte d'etnografia pot entendre's de diverses maneres segons l'autor/a: com a mètode d'investigació antropològica, com a resultat d'una investigació en forma de text o com una experiència física d'immersió total, és a dir, com a treball de camp (v. 3.2.1). L'enfocament d'aquesta tesi, per exemple, és etnogràfic perquè compleix amb els requisits que Nolla (1997) i Cerri (2012) associen a aquesta ciència: analitza els valors i les opinions dels participants de São Tomé i Príncipe des de 
l'observació i la descripció de les seues intervencions, enregistrades durant una immersió física al país (treball de camp).

Una vegada aclarides aquestes definicions relacionades amb l'etnografia, cal fer una ullada a la seua història per a identificar els inicis d'aquesta pràctica. Si s'aprofundeix al passat de l'etnografia amb l'objectiu d'intentar identificar els pioners d'aquesta ciència, entre els primers investigadors que van descriure creences, tradicions $\mathrm{i}$ formes de vida dels pobles estan Heròdot (Grècia, segle v a.C.), que va viatjar a Egipte, Fenícia, Líbia, les costes meridionals del mar Negre i potser també a Babilònia; i Tàcit (Roma, segle I d.C.), que relata aspectes culturals dels pobles germànics (Clair, 2003; Recasens, 2018; Ugwu, 2016). Després, molts viatgers, missioners, etc. van realitzar registres informals sobre les seues experiències, però no complien els mètodes d'investigació necessaris que s'expliquen més endavant per a ser considerats etnògrafs fins l'arribada del missioner jesuïta Joseph François Lafitau a Canadà l'any 1712 (Ugwu, 2016). Lafitau va escriure sobre els iroquesos, la tribu de natius amb qui va viure durant quasi sis anys. Hi va aprendre la seua llengua i la seua cultura com es reflecteix a l'estudi Moeurs des sauvages Amériquains, comparées aux moeurs des premiers temps, publicat l'any 1724 (Ugwu, 2016). Moltes més investigacions el van seguir al llarg del temps: durant l'època colonial, la Primera i Segona Guerra Mundial, amb l'arribada de la globalització, etc. (Clair, 2003). La Primera Guerra Mundial, per exemple, va portar l'antropòleg Malinowski (considerat un dels pares de l'etnografia) a l'exili a Nova Guinea (de Almeida, 2004; Silva i Mathias, 2018; Ugwu, 2016) des d'on va escriure uns quaderns etnogràfics sobre els habitants de les illes Trobriand (Ugwu, 2016); i la Segona Guerra Mundial va propiciar estudis d'altres països i regions, com els realitzats per Leach a Birmània (actual Myanmar) sobre la tribu Kachin (de Almeida, 2004; Tambiah, 2002) o els de 
Benedict sobre el comportament i la cultura dels japonesos (de Almeida, 2004; Lummis, 2007; Ryang, 2004; Scheer et al., 2010).

Cada nova etapa històrica ha comportat nous objectes d'estudi etnogràfic en diferents parts del món per a reflectir la realitat d'un grup de persones en un moment i en un Iloc determinats. Aquesta tendència s'ha estès fins a l'actualitat i s'aplica en diferents àmbits d'estudi que requereixen una investigació qualitativa sobre algun aspecte cultural o de comportament d'una societat o un grup d'individus, com ara:

1. L'etnografia de la comunicació, que estudia les pràctiques de comunicació de l'esser humà (Moncayo, 2016), com els recursos sociolingüístics d'una comunitat i les seues variables lingüístiques, de quina manera s'utilitzen aquests recursos en la interacció social i el discurs, la relació que tenen amb la cultura de la comunitat que s'estudia, etc. (Prado, 2007). L'etnografia de la comunicació analitza els esdeveniments comunicatius en la seua totalitat. En definitiva, l'etnografia de la comunicació tracta no només el comportament verbal de les persones, sinó també els no verbals - gestos, signes, dibuixos, xiulits, etc.- (Rodríguez Luna, 1997).

2. L'etnografia digital, que considera que la ràdio, la televisió, internet, els telèfons digitals, els ordinadors, etc. han aportat nous elements a les relacions interpersonals que han canviat la forma de relacionar-se de les persones i s'encarrega, precisament, d'estudiar aquestes noves relacions (Moncayo, 2016; Mosquera, 2008).

3. L'etnografia de l'educació busca mostrar i comprendre la realitat que es manifesta al context escolar 
mitjançant dades que s'aporten de la forma més descriptiva possible i que s'interpretaran posteriorment (Álvarez Álvarez, 2008; Maturana i Garzón, 2015). Suposa un tipus d'investigació especialment adient en l'àmbit educatiu, ja que els xiquets i les xiquetes absorbeixen la cultura que els envolta des del seu naixement i també són portadors d'aquesta cultura quan comencen a socialitzar; tenen una visió particular del món i adopten infinitat d'estímuls externs que internalitzen i, per tant, poden interpretar i explicar la seua realitat (Parra Sabaj, 1998). A més, per a l'investigador/a docent, resulta natural realitzar la fase del treball de camp, ja que es tracta del seu àmbit de treball habitual (Maturana i Garzón, 2015).

4. L'etnolingüística s'ocupa d'analitzar la relació que existeix entre les llengües i les cultures, la qual cosa pot servir per a explicar per què una llengua és i s'utilitza d'una determinada manera (Martín Camacho, 2018). Encara que per a Gómez Rodríguez (2003) els termes lingüística antropològica, etnolingüística i antropologia lingüística poden utilitzar-se indistintament segons la preferència dels autors, per a Coseriu (1981) l'etnolingüística s'ha d'encarregar d'estudiar la connexió entre la llengua i la cultura des de dues perspectives diferents: aquella que analitza com la cultura condiciona la llengua que es parla, i aquella que estudia els trets culturals que reflecteix la Ilengua. Com expliquen Teillier et al. (2016), les Ilengües representen la realitat dels seus parlants i no és possible separar els aspectes lingüístics, socials i culturals d'una societat, ja que són conceptes que es retroalimenten: la llengua és l'expressió d'una cultura i condiciona la comprensió de la realitat dels seus parlants. 
Els exemples anteriors mostren que l'etnografia és una ciència flexible, ja que, com s'ha vist, permet la seua combinació amb altres camps d'estudi diferents per buscar uns resultats qualitatius emmarcats dins d'una investigació relacionada amb la cultura o el comportament social d'una comunitat. Tenint aquesta informació present, per tant, per a poder identificar una investigació com a etnogràfica, cal fixar-se més en el mètode d'investigació i no tant en l'àmbit de coneixement. Rockwell (2009) indica alguns criteris indispensables:

1. L'etnògraf ha d'exposar els resultats de la seua investigació de manera descriptiva.

2. L'etnògraf ha de ser cronista i documentar allò que no està documentat de la realitat social.

3. L'etnògraf ha de tindre una experiència directa $i$ prolongada en la localitat objecte d'estudi.

4. L'etnògraf ha d'intentar comprendre la visió dels natius i el coneixement local que estudia. Per tal d'aconseguir-ho, és essencial establir una col-laboració estreta amb els i les locals, mantindre obertura a les seues formes d'entendre el món i respectar els seus coneixements.

5. El treball de l'etnògraf ha de ser flexible $\mathrm{i}$ obert. S'acompanya d'un treball mental constant que permet una major observació i obertura a la sorpresa.

En definitiva, l'etnografia suposa una tècnica d'investigació aplicable a nombrosos àmbits de coneixement; es tracta d'una ciència descriptiva i que implica la immersió de l'investigador o la investigadora durant el treball de camp. Segons Recasens (2018), de vegades l'etnografia es posa en dubte perquè 
no és objectiva i la seua metodologia no segueix els cànons de la ciència, però en realitat proporciona una base comparativa sobre el comportament i la forma de vida de diverses comunitats perquè amplia els coneixements que es tenen sobre diferents pobles i grups d'individus. És a dir, l'evidència que mostra l'etnografia reitera en el temps i l'espai que les societats s'organitzen al voltant d'idees, recursos i formes de relacionar-se que, a més a més, solen ser conseqüents amb el medi ambient en què viuen (Recasens, 2018).

A continuació, s'aprofundeix en els elements que conformen el mètode etnogràfic: el pla d'acció i la corroboració de dades etnogràfiques com el treball de camp o la triangulació de dades, i que són característiques d'aquest tipus d'investigació.

\subsection{ELEMENTS DE LA INVESTIGACIÓ ETNOGRÀFICA}

La investigació etnogràfica proporciona descripcions que són valuoses en sí mateixes i pot utilitzar-se en qualsevol moment d'una investigació o combinar-se amb altres estratègies i modalitats (Galeano, 2004) com s'ha explicat en l'apartat anterior. Es tracta d'un tipus d'investigació circular en la qual s'identifiquen fases que poden donar-se de manera simultània, com l'accés al camp (en què l'investigador intenta guanyar-se la confiança de les persones que estudiarà 0 de les quals es despendrà part del seu estudi) o el treball de camp, que es desenvolupa allà on es troben els individus que es pretén estudiar i on s'apliquen tècniques de recull de dades imprescindibles per a la investigació etnogràfica: observació participativa, entrevistes, anàlisi documental, anàlisi de dades, etc. (Álvarez Álvarez, 2008). A més a més, a causa del caràcter subjectiu i difícil de valorar que suposen les dades etnogràfiques, aquesta ciència compta amb ferramentes 
específiques per a l'anàlisi de dades, com la triangulació (Benavides i Gómez-Restrepo, 2005).

\subsubsection{Pla d'acció}

Assolir els objectius d'una investigació etnogràfica suposa el disseny d'un pla d'acció específic. San Vicente (2010), per exemple, proposa el següent:

- Reflexió, documentació i bibliografia: primerament, cal establir unes bases teòriques per extraure els objectius i l'índex de la investigació. A continuació, convé buscar bibliografia més específica relacionada amb el context històric, geogràfic, etc. d'allò que es vol estudiar i també buscar la col-laboració de persones pròximes a les localitzacions on es desenvoluparà el treball, ja que poden aportar bibliografia difícil de trobar i de gran interès, encara que no estiga escrita per persones altament qualificades.

Planimetria: els plànols de la localització on s'hi treballarà poden servir de referència per contextualitzar el treball i organitzar els desplaçaments i el cronograma d'acció necessaris per desenvolupar la investigació.

- $\quad$ Treball de camp: és el treball que es desenvolupa a la localització objecte d'estudi. És recomanable preparar una fitxa adaptada al tema d'investigació per a facilitar el recull de dades; també fotografiar i realitzar vídeos curts per tindre una base documental visual de l'estudi; entrevistar informants sobre el tema d'estudi mitjançant entrevistes guiades per facilitar l'obtenció de la informació que es necessita. Els informants han de decidir si estan d'acord que se'ls grave $i$ es recullen les seues dades 
personals. És positiu que s'hi compartisquen les inquietuds de la investigació i que se senten partícips del treball.

Entrevistes: les entrevistes semiestructurades amb un guió preestablert serveixen per aconseguir dades mitjançant una conversa dirigida. És recomanable explicar els entrevistats en què consisteix la investigació i la importància de la seua participació. Les persones entrevistades s'elegeixen pels seus coneixements, per la seua edat o pels treballs que han realitzat. Durant aquestes converses, l'entrevistador/a pot relacionar el tema de l'entrevista amb altres qüestions que puguen sorgir de forma espontània i que poden aportar informació sobre aspectes que no s'havien contemplat durant la planificació inicial de la investigació (v. 6.3.1).

- Gravació i documentació: només es gravarà si les persones entrevistades donen permís, havent-los oferit l'opció d'una gravació visual o una gravació d'àudio. S'aconsella fer ús de notes de camp per registrar possibles dades o impressions interessants de les entrevistes només realitzar-les. Aquesta presa de notes ajuda a la creació d'hipòtesis de treball i a la formació de les conclusions finals (v. 6.3.3).

- Observació participant: consisteix a conviure a la localització i amb les persones objecte d'estudi. És una forma de recollir informació que es desenvolupa durant un temps prolongat.

- Informe i conclusions: l'informe i les conclusions finals es redacten després d'una anàlisi exhaustiva dels resultats obtinguts. 
A més d'aquests mètodes d'investigació etnogràfica que proposa San Vicente (2010), altres autors utilitzen de manera complementària el grup de discussió (Callejo, 2002; Castaño et al., 2017; Fàbregues i Paré, 2010; García i Martínez, 2012), que s'ha consolidat com una de les ferramentes més utilitzades per recollir informació qualitativa (Fàbregues i Paré, 2010).

Per la rellevància que té en aquesta tesi (v. 6.3.2), la tècnica del grup de discussió mereix una explicació específica. Es tracta d'una activitat que consisteix en un diàleg o un debat grupal sobre un tema proposat (Castaño et al., 2017) i està conduït per un moderador o moderadora (Callejo, 2002; García i Martínez, 2012). La tasca de moderació implica no expressar opinions personals, dirigir la reunió i afavorir les conclusions finals del debat (García i Martínez, 2012). Allò que diferencia aquesta tècnica de les que s'han explicat anteriorment, és que el grup de discussió (idealment format per entre 5 i 10 persones en igualtat de condicions i coneixements sobre la qüestió que ha de tractar-se) (Castaño et al., 2017) permet que els participants compartisquen i modifiquen els seus punts de vista a mesura que avança el debat (Fàbregues i Paré, 2010). A més, com defineixen Castaño et al. $(2017$, p. 18$)$ :

[...] los GD [grupos de discusión] son muy útiles para validar otros instrumentos de encuesta, abordar temas de difícil acceso [...], facilitan la colaboración de participantes más reacios a entrevistas individuales y dan voz a preocupaciones no expresadas.

El pla d'acció que s'ha seguit en aquesta investigació segueix el disseny que proposa San Vicente (2010), 
com s'especifica a l'apartat 6.1, a més de la utilització de grups de discussió com a eina per a recollir informació (v. 6.3.2).

\subsubsection{La triangulació}

Com assenyala Recasens (2018), la metodologia etnogràfica aporta informació subjectiva i, precisament a causa de la dificultat de valorar l'objectivitat i l'aplicabilitat de les tècniques d'investigacions etnogràfiques, la triangulació es presenta com una ferramenta d'anàlisi de dades que aporta fortalesa a les investigacions qualitatives (Benavides i Gómez-Restrepo, 2005). Aquesta tècnica se centra en contrastar diferents visions 0 enfocaments a partir de les dades obtingudes i permet visualitzar una part d'una investigació des de diferents angles, de manera que augmenta la validesa i consistència dels resultats. La triangulació corrobora els descobriments d'una investigació quan les estratègies aporten conclusions semblants i, quan no ho fan, ofereixen l'oportunitat d'elaborar una perspectiva més àmplia, ja que assenyala la complexitat de l'assumpte que s'estudia i permet nous plantejaments. Per això, la triangulació no només serveix per a validar informació, sinó que també s'utilitza per ampliar i aprofundir en la seua comprensió (Benavides i Gómez-Restrepo, 2005).

Es poden realitzar diferents tipus de triangulació. La majoria d'investigadors identifiquen la triangulació de dades, que se centra a contrastar diferents fonts de dades que poden trobar-se en diferents localitzacions, dates i extraure's de diferents persones; la triangulació d'investigadors, que implica la participació de més investigadors per a generar diferents perspectives; la triangulació teòrica, que treballa amb diferents conceptes i teories per afavorir la comprensió de les dades obtingudes; i la triangulació metodològica, que es basa en la comparació i el contrast de diferents mètodes per tindre una major 
comprensió del fenomen que s'estudia (Reeves et al., 2008; Tiainen i Koivunen, 2006). Guion et al. (2011) distingeixen també la triangulació ambiental, encara que aquest tipus de triangulació només pot utilitzar-se en aquelles matèries d'estudi que puguen ser influenciades per factors ambientals. Així, la triangulació ambiental implica l'observació dels canvis que es manifesten al fenomen que s'estudia segons els factors mediambientals com l'estació de l'any, I'hora o el dia en què es desenvolupa, per exemple.

Tots aquests elements conformen alguns dels mètodes més característics de les investigacions etnogràfiques $i$ faciliten la comprensió d'una realitat aliena de la mà de les persones que la viuen i al terreny on es desenvolupa. A São Tomé i Príncipe concretament, diversos investigadors/es han realitzat diferents estudis amb el treball de camp com a denominador comú i sovint també amb altres tècniques que s'expliquen en l'apartat 3.2, com les entrevistes. En l'apartat següent es donen alguns exemples d'investigacions etnogràfiques que s'han realitzat en aquest país.

\subsection{INVESTIGACIONS ETNOGRÀFIQUES SOBRE SÃO TOMÉ I PRÍNCIPE}

São Tomé i Príncipe ha sigut escenari de diverses investigacions etnogràfiques que responen a diferents interessos acadèmics o àmbits de coneixement. Des d'una de les primeres, História ethnographica da ilha de S.Thomé (Negreiros, 1895), en la qual l'autor fa un repàs de la història de l'illa de São Tomé, d'alguns aspectes del crioll forro i exposa el seu punt de vista respecte a les ètnies de l'illa, les tradicions i les creences, etc., han sigut molts els acadèmics que han escollit São Tomé i Príncipe com a localització per a les seues investigacions. A 
continuació se citen algunes de les investigacions etnogràfiques més recents que es troben relacionades amb la temàtica d'aquesta tesi.

Máscara, mato e morte (Valverde, 2000), és un llibre centrat inicialment en la tradició del txiloli, també coneguda com Tragédia do Imperador Carlos Magno e do Marquês de Mântua, una representació teatral sobre la mort i la traïció amb una gran presència de la música i l'expressió corporal ${ }^{3}$. Aquest llibre és una obra pòstuma $\mathrm{i}$ inacabada ja que, dissortadament, Valverde va morir abans de poder finalitzar la seua investigació. Es tracta d'un recull d'escrits dividits entre cartes, notes i diaris de camp escrits per Valverde als quals reflecteix les seues impressions durant l'estada al país, els escrits que fan referència als seus descobriments sobre el txiloli i els que fan referència al curanderisme i la fetilleria.

Per la seua banda, Feio (2008) investiga la relació entre la identitat ètnica i la identitat personal dels angolars de São Tomé i Príncipe (v. 5.2.1) tenint en compte com les diferències econòmiques, socials i culturals interfereixen en aquesta relació. Aquesta autora també estudia la situació dels capverdians i descendents de capverdians (v. 5.2.1), com es relacionen amb altres ètnies del país, de quina manera els ha influït el seu passat històric a São Tomé i Príncipe, com han canviat o com es mantenen els preconceptes ètnics i quina és la interpretació que fa aquesta comunitat de la seua pròpia identitat a través d'una investigació basada en la convivència amb diferents famílies (Feio, 2016a). A més, Feio (2016b) contribueix amb la publicació d'algunes de les seues experiències i pensaments més personals com a antropòloga durant les seues estades al país, la qual cosa aporta la visió d'una

\footnotetext{
${ }^{3}$ https://tchiloli.com/
} 
investigadora estrangera a mesura que avança en la seua recerca etnogràfica.

Les investigacions d'Agostinho (2015) i Bouchard (2017), encara que es tracta d'investigacions lingüístiques, també se sustenten d'una metodologia amb aspectes etnogràfics. La primera estudia la fonologia i presenta un mètode pedagògic del lung'ie a Príncipe (v. 5.2.2) mitjançant la utilització i l'ampliació de diversos corpus i una sèrie d'entrevistes enregistrades durant el treball de camp. El treball de camp i la col-laboració d'informants locals va servir, entre d'altres coses, per estudiar la fonologia i la morfosintaxi del lung'ie, preparar els textos que s'utilitzarien a la proposta pedagògica d'aquesta llengua, enregistrar parlants natius que llegien aquests textos, recollir dades per a un diccionari lung'ieportuguès/portuguès-lung'ie amb l'objectiu d'augmentar el vocabulari temàtic de cada unitat pedagògica, etc. (Agostinho, 2015). Bouchard (2017), en canvi, investiga la varietat dialectal del portuguès que es parla a São Tomé i Príncipe i els fenòmens ideològics i socials que expliquen les varietats lingüístiques i canvis que s'hi produeixen a través d'un treball de camp durant el qual va entrevistar 56 persones de la capital del país o de les seues proximitats.

Una altra investigació que cal destacar, tot i que s'allunya dels aspectes lingüístics i d'identitat que sí que integren els estudis que s'esmenten anteriorment, és la que realitza Madureira (2012) sobre les plantes medicinals i la medicina tradicional a São Tomé i Príncipe. Aquest estudi etnofarmacològic es basa en un treball directe amb terapeutes tradicionals del país (normalment persones ancianes) entre els anys 1993 i 2010, amb els quals es va recollir, estudiar i identificar unes 360 espècies de plantes medicinals i més de 1.000 receptes tradicionals. Es va investigar l'efecte d'aquestes plantes i receptes en les malalties amb 
major incidència al país, com la malària, per seleccionar aquelles que es demostren segures, eficaces i accessibles per integrar-les al sistema de salut nacional (Madureira, 2012).

Com es pot veure, São Tomé i Príncipe genera un interès molt variat entre diferents àmbits de coneixement. Es tracta d'un país que ofereix nombroses possibilitats d'estudi per a les quals resulta especialment adient l'aplicació de mètodes etnogràfics que permeten un treball de camp que es beneficie de la proximitat amb persones locals. Aquesta tesi no és una excepció i també es serveix d'una metodologia etnogràfica, ja que ha sigut necessari el desenvolupament d'un treball de camp, a més de tècniques com les entrevistes, els grups de discussió i la triangulació de dades, com s'explica en l'apartat 6.1. 


\section{LA COOPERACIÓ}

És important saber que la cooperació no té una definició concreta i invariable, ja que es nodreix dels canvis de valors, pensaments i sentit de la responsabilitat que les societats dominants adquireixen o abandonen amb el pas del temps front a les situacions precàries que es viuen en altres parts del món. Per arribar a comprendre el significat actual d'aquest concepte, resulta especialment adient tindre present el context i el desenvolupament històric de la cooperació. A continuació, s'expliquen conceptes específics de la cooperació que tenen a veure amb els objectius que planteja aquesta tesi i analitzarem la seua relació i les seues possibilitats amb l'àmbit de la traducció i el material audiovisual.

\subsection{HISTÒRIA I EVOLUCIÓ}

Els conceptes de Tercer Món i desenvolupament van nàixer després de la Segona Guerra Mundial a Occident, però si existeix un moment històric fonamental en la concepció de la cooperació, va ser el gener de 1949, quan el llavors President dels Estats Units, Harry S. Truman, va presentar el Pla Marshall. La concepció d'aquest pla es va esdevenir per la desmesurada necessitat d'ajuda a l'Europa de la postguerra i tenia tres objectius: evitar que la situació d'Europa afectara l'economia nord-americana, prevenir l'expansió del comunisme i afavorir la consolidació de règims democràtics (Magid, 2012; Tucker, 1997). Aquest pla es va donar en un context molt especial que va afavorir la creació d'institucions com les Nacions Unides (ONU), el Banc Mundial (BM) o el Fons Monetari Internacional (FMI), a més de 
l'Organització per a la Cooperació i Desenvolupament Econòmic (OCDE) i el Comité d'Ajuda al Desenvolupament (CAD), i va suposar una important donació econòmica a Europa per part dels Estats Units a més d'un discurs que catalogava com a bona acció aquesta forma d'entendre la Cooperació Internacional al Desenvolupament (CID) (Lemus Delgado, 2017). D’acord amb la definició de l'ONU (1945), la Cl podria definir-se com una col-laboració entre diversos actors per solucionar problemes de tipus econòmic, social, cultural o humanitari, tenint en compte el desenvolupament, els drets i les llibertats humanes, sense cap classe de distinció.

No obstant això, cal tindre present que, en aquesta època, s'estaven desmembrant les antigues colònies europees a Àsia i Àfrica, la qual cosa significava l'aparició en escena de nous països independents, plens de carències i desavantatges geogràfics. A més, l'ajuda es veia com una moneda de canvi per obtindre suport polític i guanyar aliats (Lemus Delgado, 2017).

Per tal de comprendre la situació actual de la CID, és necessari analitzar, a més dels esmentats esdeveniments històrics, un acord internacional pres als inicis del nou segle, els Objectius de Desenvolupament del Mil-leni (ODM), i de quina manera han variat fins a l'actualitat i han influït en la concepció de les ONG com a factors fonamentals a la CID. Quant als ODM, cal saber que també van ser clau al procés històric de la CID, ja que van suposar garantir que els recursos dels països donants s'utilitzen amb eficàcia. El CAD va contribuir a aquests objectius assenyalant la necessitat de pensar menys en l'ajuda i més en la cooperació, entenent-la com una associació entre els països donants i els països en vies de desenvolupament (Lemus Delgado, 2017).

Els vuit ODM es van fixar l'any 2000 i suposaven el compromís dels països que formen part de l'ONU 
d'acomplir-los per a l'any 2015 i contribuir així al desenvolupament humà. Actualment en són 17 i se'ls coneix com Objectius de Desenvolupament Sostenible (ODS) (Sanahuja, 2007). Com indiquen a la web del Programa de las Naciones Unidas para el Desarrollo (2019), els ODS amplien els antics ODM i inclouen la lluita contra el canvi climàtic i la desigualtat econòmica, la innovació, el consum sostenible, la pau i la justícia, entre altres aspectes.

Com que aquesta tesi es planteja en un context de cooperació a São Tomé i Príncipe, i per a poder emmarcar correctament aquesta proposta i el tipus de cooperació que suposaria, convé revisar el paper històric que han tingut les ONG a la CID.

Durant un temps es va afavorir la consolidació de les organitzacions com un actor important de l'ajuda internacional (Lemus Delgado, 2017), però actualment, i des de l'última crisi econòmica, el sector privat s'ha involucrat en els projectes contra la pobresa, per la qual cosa la definició de cooperació ha tornat a canviar i comença a respondre a la lògica del mercat, mentre els moviments socials i les ONG s'han vist relegades a un paper residual (Ramiro, 2013; Carrión i Martí, 2013). Aquest fet s'ha convertit en un dels principals temes de l'agenda política, ja que alguns dels arguments que s'esgrimeixen fan referència a l'augment de fons per part del sector privat dirigits a projectes de desenvolupament, o la creença que la presència del sector privat en països empobrits contribuirà a dinamitzar el desenvolupament $i$ l'economia local. No obstant això, diferents ONG qüestionen les pràctiques i l'impacte social, ambiental i cultural de les empreses transnacionals als països del Sud i creuen que la seua entrada al món de la cooperació només servirà per a afavorir els negocis empresarials (Ramiro i Pérez, 2011; Carrión i Martí, 2013; CSA, s/d). 
Tot i que sembla que aquests canvis no tenen marxa enrere, encara existeix un marge d'actuació per a organitzacions que treballen per una transformació social. Segons Ramiro (2013), és necessari aprofitar-se'n i crear noves agendes de cooperació alternatives per tal d'avançar cap a altres horitzons emancipadors. És en aquesta idea de cooperació en la qual se situa la proposta d'aquesta tesi (v. 8.2). Martínez Osés (2013, s/p) assenyala:

[...] el desarrollo de la nueva agenda post 2015 debe estar estrechamente vinculado al cumplimiento de todos los derechos humanos. Debe estar medido en términos de satisfacción de necesidades y oportunidades, mucho más cerca de la idea de felicidad humana que de la idea de crecimiento.

\subsection{CONCEPTES DE COOPERACIÓ}

Dins la idea col-laborativa que suposa la cooperació, es poden trobar diferents conceptes que donen una imatge més completa del que és aquesta pràctica, quins són els objectius que persegueix i les activitats que la caracteritzen. Tenint açò en compte, analitzem a continuació la cooperació al desenvolupament, l'educació per al desenvolupament, la sostenibilitat, la justícia social i la cooperació lingüística, conceptes que també s'exposen en un esquema-resum que es presenta al final d'aquest capítol (v. II·lustració 2). 


\subsubsection{Cooperació al desenvolupament}

La cooperació al desenvolupament és tota aquella cooperació que propose donar suport a les prioritats de desenvolupament nacional $o$ internacional sense ànim de lucre $i$ discriminar en favor dels països en vies de desenvolupament a través de relacions de col-laboració que n'intenten millorar la situació. No es redueix a la transferència de recursos, sinó que engloba qualsevol activitat que haja sigut planificada específicament per impulsar l'avanç de països en vies de desenvolupament (Alonso i Glennie, 2015). És en aquest concepte on s'emmarca l'objectiu principal d'aquesta tesi, valorar la subtitulació com a eina per a la cooperació en São Tomé i Príncipe.

Des del seu origen, la CID ha estat marcada per la Guerra Freda i el passat colonial de molts països europeus. La Guerra Freda va propiciar que el Govern dels Estats Units es comprometera a aportar recursos a altres països per tal d'atraure'ls a la seua esfera d'influència; l'Europa excolonial, en canvi, tenia un cert sentit de la responsabilitat per l'estat en què es trobaven les antigues colònies per culpa de les carències bàsiques en infraestructures i recursos que els havien deixat (HEGOA, 20052006).

Aquest tipus de cooperació implicava una posició d'inferioritat dels països necessitats front als països donants, ja que es va entendre com una activitat voluntària i generosa, $i$ deixava aquells que rebien l'ajuda sense dret de reclamar (HEGOA, 2005-2006). A més, l'ajuda es va centrar en la millora d'infraestructures, perquè es pensava que això impulsaria el creixement econòmic. En canvi, als anys 70-80 van començar a esdevenir-se alguns canvis a la percepció que es tenia de la CID (Lemus Delgado, 2017). 
En primer lloc, es va entendre que el creixement econòmic no garantia la correcta educació i nutrició de les persones $i$, en conseqüència, es va començar a plantejar una idea d'ajuda més dirigida a satisfer les necessitats humanes bàsiques. En segon lloc, els països donants van establir condicions als països en desenvolupament, com estabilitzar les seues economies, liberalitzar el comerç i altres reformes estructurals, així com recomanacions polítiques. En tercer lloc, la pobresa mundial va començar a ocupar més espai als mitjans de comunicació, cosa que va consolidar les ONG i les institucions filantròpiques (Lemus Delgado, 2017).

Després de la decepció de no haver superat la pobresa, la disminució del finançament destinat al desenvolupament $\mathrm{i}$ les crítiques a les pràctiques tradicionals de cooperació, als anys 90 hi va haver un nou canvi de pensament, que posava les persones al centre. Llavors es van crear els ODM, que van contribuir al fet que el concepte d'ajuda es substituïra pel de cooperació i que la CID es considerara com una associació entre països i no com un acte de caritat (Lemus Delgado, 2017). Aquest nou enfocament ha introduït noves perspectives on la CID troba àmbits de treball per crear una societat més justa: la participació; la igualtat entre sexes i països, i entre persones dins de cada país; les llibertats polítiques; els drets humans, etc. (HEGOA, 2005-2006).

Per tant, actualment, hi ha tres tipus principals de cooperació al desenvolupament, segons Alonso i Glennie (2015):

1. Transferències financeres: aquest tipus d'ajuda suposa una donació econòmica, i encara és essencial per al desenvolupament. No augmentar les transferències als països més empobrits dificulta considerablement els 
progressos en altres àrees, com les que formen part del foment de la capacitat.

2. Foment de la capacitat: aquesta cooperació suposa el suport amb recursos organitzatius i humans, la cooperació tecnològica i en altres sectors per afavorir l'autonomia i la capacitat dels països en desenvolupament. La proposta d'aquesta tesi, per exemple, s'emmarcaria en aquest espai.

3. Canvi normatiu: aquesta línia d'actuació implica que els països donants asseguren normes per aconseguir una distribució més equitativa de les oportunitats de desenvolupament entre països i una provisió eficient dels béns públics internacionals.

Per últim, cal tindre en compte que, encara que la cooperació per al desenvolupament forma part de la $\mathrm{Cl}$, hi ha camps d'aquesta última que no es relacionen directament amb el desenvolupament (l'adopció de mesures preventives contra el terrorisme en seria un exemple) i, per tant, han de tractar-se com a conceptes diferents (Alonso i Glennie, 2015). La Cl podria definir-se com l'activitat conjunta entre tots els actors que participen per assolir un objectiu comú, és a dir, el mitjà per canalitzar l'ajuda cap als països beneficiaris per tal d'impulsar el desenvolupament tant d'aquells que la reben, com els que l'ofereixen (Lo Brutto, 2017). Tampoc ha de confondre's la $\mathrm{Cl}$ amb l'ajuda internacional, que comporta únicament la transferència de recursos d'un país més desenvolupat a un altre menys desenvolupat (Fernández Salinas, 2018). 


\subsubsection{Educació per al desenvolupament}

D'acord amb la definició que es dona a la web de l'Agencia Española de Cooperación Internacional para el Desarrollo (AECID) ${ }^{4}$ :

La Educación para el Desarrollo facilita la
comprensión del mundo globalizado, provoca
una actitud crítica y comprometida con la
realidad, genera compromiso y
corresponsabilidad en la lucha contra la
pobreza, fomenta actitudes y valores en la
ciudadanía, genera en definitiva una ciudadanía
global. («Piensa globalmente, actúa
localmente»).

L'Educació per al Desenvolupament (ED) és una dimensió estratègica de la cooperació espanyola (Ortega, 2008) i treballa des de diferents àmbits perquè els ciutadans estiguen més informats, més conscienciats i siguen més participatius (Portal Web AECID, s/d). No obstant això, la definició d'ED ha evolucionat des de la seua concepció primera fins als nostres dies, ja que es veu condicionada inevitablement per com es desenvolupen les distintes formes d'entendre el món al llarg del temps. Com expliquen Santos i Romero (2016), als anys 50 l'ED pren un caràcter caritatiuassistencial, i les accions puntuals que es realitzen no són de massa qualitat atès que la sensibilització es dona a partir de les conseqüències de la pobresa, però sense analitzar-ne les causes.

$4 \quad$ https://www.aecid.es/ES/la-aecid/educaci\%C3\%B3n-y-sensibilizaci\%C3\%B3n-para-eldesarrollo/\%C2\%BFqu\%C3\%A9-es-la-educaci\%C3\%B3n-para-el-desarrollo 
Als anys 60 s'aprecia un major desenvolupament, ja que apareixen les primeres idees de cooperació per ajudar els països menys desenvolupats per tal que s'ajuden a si mateixos. Als 70 s'adopta una mirada més crítica i s'assumeix la responsabilitat dels països desenvolupats en relació amb la pobresa dels països del Sud, i es qüestiona el model de desenvolupament ideal que representen els països rics. Durant els anys 80 es considera I'ED com una finalitat que té el deure de promoure la comprensió dels problemes NordSud i tindre una repercussió a la vida quotidiana, perquè el canvi global depén tant del Sud com del Nord. Per últim, la generació de finals dels 90 critica el model de globalització i promou una consciència de ciutadania global, la globalització de la solidaritat i la pertinença de tots els individus a una societat mundial. Aquesta perspectiva permet reivindicar una ciutadania informada, crítica i participativa, que és capaç d'analitzar les situacions de subdesenvolupament i lluitar per tal de superar-les.

L'ED és, per tant, un procés d'aprenentatge actiu i basat en la solidaritat, la igualtat, la inclusió i la cooperació que permet que les persones puguen aprofundir en l'enteniment de les causes i els efectes de la globalització i encaminar-se cap a un compromís personal i una acció basada en la informació (Lappalainen i Álvarez Rivas, s/d). Aquest procés educatiu es manifesta en quatre etapes diferenciades: sensibilització, educacióformació, incidència política i mobilització social i, finalment, investigació (Ortega, 2008).

La sensibilització es tradueix en la conscienciació a través de la informació d'aquelles competències que alerten sobre la pobresa, els drets i les estructures que la perpetuen, un coneixement de les realitats del Sud i de les pràctiques que generen desigualtats (Portal Web AECID, s/d). 
L'educació-formació pretén formar en continguts, habilitats i valors a mitjà i llarg termini. Açò permet aprofundir en l'anàlisi de les causes de la pobresa i en les propostes de canvi (Ortega, 2008).

El principal objectiu de la incidència política és influir en les decisions polítiques que poden afectar estructures socials, econòmiques o polítiques tant en esferes locals com en esferes globals. Les accions d'incidència política plantegen alternatives orientades al desenvolupament humà i sostenible i solen anar acompanyades d'accions de mobilització social (Ortega, 2008). La mobilització social implica la participació de la ciutadania en processos de canvi polític i transformació d'estructures socials, econòmiques i polítiques $\mathrm{i}$, per tant, suposa també la seua participació en la lluita contra la pobresa i la promoció del desenvolupament humà (Portal Web AECID, s/d).

La investigació permet una anàlisi profunda del desenvolupament i aporta propostes. Es basa en tècniques d'investigació social, especialment la investigació-acció (Portal Web AECID, s/d). Cal assenyalar que la investigació per al desenvolupament ha de ser interdisciplinària, ja que es nodreix de diferents camps de treball per oferir anàlisis més completes i consistents (Ortega, 2008).

Al cas concret de São Tomé i Príncipe i del projecte de cooperació que proposa aquesta tesi (sensibilització sobre la situació dels ancians a través de la subtitulació de la seua llengua), aquestes quatre fases són de gran importància per tal d'obtindre resultats satisfactoris: la sensibilització de la població envers aquest problema, la incidència política per establir compromisos ferms per pal-liar la marginació dels ancians, la mobilització social d'aquelles persones que ja estan sensibilitzades i 
volen canviar la situació i la investigació, que aportaria informació valuosa sobre l'origen d'aquestes discriminacions, els ancians més susceptibles $\mathrm{i}$ el perfil i els motius de les persones que tenen prejudicis (v. 8.2).

\subsubsection{Cooperació lingüística}

Existeixen diferents formes d'entendre la cooperació lingüística. L'ambaixada de França a Bolívia (2019) i Macías (2012), per exemple, fan ús d'aquest terme per definir la promoció de la llengua francesa i la cooperació entre el sistema educatiu francès i el d'Espanya, Bolívia i Equador respectivament. No obstant això, si des del punt de vista de la traducció enllacem les idees que defensen Ramiro (2013) i Martínez Osés (2013) (v. 4.1) sobre la necessitat de crear noves agendes de cooperació alternatives que es desenvolupen en base a la satisfacció de necessitats i oportunitats, i de situar-se més a prop del concepte de felicitat humana que del de creixement, podem pensar en la possibilitat d'integrar la cooperació lingüística en projectes de CID. Tot i que no és la variant de cooperació més estesa, sens dubte seria clau en algunes societats on part de la població viu discriminada per la seua cultura o llengua. En paraules d'Abarrategi (2016, s/p):

La justicia social necesita la aportación de las minorías, también de las minorías lingüísticas. [...] Y a la cooperación que quiere vincularse a ese objetivo le es imprescindible beber de las identidades originarias y centrar el trabajo para generar las condiciones que permitan la vida en las lenguas originarias. 
Entenem que els drets humans estan en la mateixa línia que la justícia social (v. 4.2.3) i, per tant, és evident la necessitat de plantejar projectes per a les minories ètniques o culturals. No seria possible fer-ho satisfactòriament sense tindre en compte la seua realitat lingüística.

Les llengües són un element essencial de la identitat sociocultural dels pobles (Ayora, 2010) i, en aquest sentit, és important tindre present que, excepte l'anglès, l'alemany, el castellà, el japonès, el xinès 0 el rus, totes les llengües són minoritàries i moltes també minoritzades (v. 1.2), és a dir, que per qüestions polítiques no tenen un ús social predominant (Belmar, s/d). Curiosament, el $70 \%$ de la població mundial té com a llengua materna l'1\% de les llengües del món i el 99\% restant només les parlen el 30\% de la població (Garabide Kultur Elkartea, 2015-2016; Guyot, 2010).

Les previsions indiquen una dràstica reducció de la diversitat lingüística i cal assenyalar que les zones que patiran aquesta reducció coincideixen amb les zones amb una biodiversitat més amenaçada. És a dir, l'opressió que pateixen una majoria de llengües coincideix amb els atacs que pateix l'ecosistema de la zona on s'hi parlen (Garabide Kultur Elkartea, 2015-2016).

Els maputxes de Xile, per exemple, s'esforcen per preservar tots els aspectes de la seua cultura: la medicina tradicional, la defensa i l'ensenyament de la seua llengua —el mapuzugun—, l'artesania, la relació amb la natura, les seues tècniques agràries, la religió, etc. Es mobilitzen contra la destrucció de la selva, l'ús de transgènics o la ramaderia intensiva entre altres, i es mantenen en la primera línia dels debats polítics i socials. La integració de minories lingüístiques com aquesta permet que els 
pobles originaris puguen escapar del perill de la folklorització que amenaça alguns d'ells per l'exposició al turisme (Guyot, 2010).

La realitat és que l'extinció de llengües arriba de la mà de la pobresa i el subdesenvolupament (Garabide Kultur Elkartea, 2015-2016), d'ací la importància d'integrar als projectes de cooperació un vessant cultural i lingüístic, com es proposa en aquesta tesi. A més, la cooperació lingüística és una eina transversal que abraça moltes dimensions. Per exemple, en l'apoderament de les dones, que solen tindre un paper essencial en la transmissió cultural i la conservació de la llengua; també en les estratègies per garantir la gestió sostenible del medi ambient, ja que és en la llengua on es condensa amb més profunditat el coneixement dels equilibris ecològics que les comunitats han acumulat durant segles (Abarrategi, 2016).

L'organització Garabide ${ }^{5}$, amb seu a Guipúscoa, treballa en aquesta línia i ofereix l'experiència de revitalització de l'eusquera a altres pobles que tinguen interès a revitalitzar les seues llengües. La proposta de Garabide (2015-2016) és treballar en tres espais diferents que se solapen:

1. La cooperació entre entitats públiques de països amb minories lingüístiques per intercanviar experiències.

2. La promoció i estructuració de la cooperació lingüística a escala universitària i de centres d'investigació.

3. La gestió de les experiències de la societat civil i les iniciatives populars. Les iniciatives populars, a més, sovint

\footnotetext{
${ }^{5}$ www.garabide.eus
} 
s'avancen als programes d'administracions i universitats, per això és important aprofitar les seues idees i no permetre que queden inutilitzades.

En conclusió, la salvaguarda de la diversitat lingüística passa per la coordinació i la col-laboració de diferents camps de treball. A més, si per CID entenem la col·laboració entre diferents actors per aconseguir ajudar altres països a impulsar el desenvolupament dels seus habitants, no només sanitàriament o econòmica, sinó en tots els aspectes de la seua vida, està justificat pensar que l'àmbit lingüístic té espai per ser un d'aquests actors, també a São Tomé i Príncipe. D’aquesta manera, podem pensar que la cooperació lingüística tindria a les seues mans l'objectiu d'aconseguir apoderar culturalment i lingüística les minories, assegurar-los la igualtat d'oportunitats i drets respecte a la resta de la població i sensibilitzar la majoria en el respecte i la valoració d'aquestes comunitats.

\subsubsection{Sostenibilitat}

Segons el Diccionario de Acción Humanitaria y Cooperación al Desarrollo (HEGOA, 2005-2006), la sostenibilitat és la condició que garanteix que els objectius i els impactes positius d'un projecte de desenvolupament perduren de forma continuada després que aquest haja conclòs. No obstant aquesta definició, la realitat és que encara no hi ha una definició clara, ja que se li han associat diferents significats segons qui siga l'emissor del discurs que fa ús d'aquest concepte. Per exemple, els corrents econòmics entenen que un projecte sostenible és aquell que es puga mantindre econòmicament, mentre que els relacionats amb el camp social i ambiental interpreten que és un projecte respectuós amb el medi ambient (López, López-Hernández i Ancona, 2005). 
El concepte de sostenibilitat s'utilitza sovint en relació amb el desenvolupament sostenible, és a dir, el procés de desenvolupament que utilitza recursos mundials i els preserva per a futures generacions (HEGOA, 2005-2006). Ara bé, Gómez Contreras (2014, p. 134) alerta sobre aquesta etiqueta:

[...] no problematiza la sostenibilidad de las culturas locales sino que busca la homogeneización de las problemáticas ambientales omitiendo las diferencias existentes entre los contextos locales de cada región, enaltece la culpa de las actividades degradantes de los pobres mientras oscurece la culpa de los países contaminadores del Primer Mundo, considera a la pobreza como el principal problema del subdesarrollo y degradación ambiental promocionando al crecimiento económico como la solución a los problemas de pobreza, vincula dos conceptos contradictorios como son crecimiento económico con cuidado del ambiente, busca producir más con menos, convirtiendo los problemas ambientales en problemas de eficiencia, da por sentado una serie de construcciones de la modernidad liberal de Occidente, etc.

Davant aquest escenari, Gómez Contreras (2014) proposa un ús alternatiu del concepte de desenvolupament sostenible: sostenibilitat ecològica. La seua proposta prescindeix de la paraula «desenvolupament» per considerar que aquesta suposa posar el creixement econòmic per sobre la sostenibilitat ecològica i fa que es combinen dos conceptes 
contradictoris: el desenvolupament econòmic i la sostenibilitat ecològica.

A més de la relacionada amb l'aspecte ambiental, HEGOA (2005-2006) proposa una altra definició de desenvolupament sostenible per fer referència als mitjans que milloren la situació socioeconòmica de les persones de forma duradora, sense afectar negativament a altres persones o futures generacions i també per a referir-se als projectes de cooperació que es mantenen en el temps.

En aquest sentit, podem parlar de la sostenibilitat d'un projecte de cooperació per al desenvolupament. Aleshores, la sostenibilitat suposa un criteri fonamental per avaluar la qualitat del projecte, ja que només seran sostenibles aquelles iniciatives que introduïsquen canvis equitatius i aborden de forma duradora les causes de la vulnerabilitat estructural sense danyar el medi ambient, cosa que podria perjudicar encara més els beneficiaris. Per tal de garantir la sostenibilitat dels projectes, cal assegurar-se que els encarregats del seu manteniment disposen de la capacitat tècnica i de gestió necessàries per a mantindre'l i suficients recursos per a finançar el procés i els costos relacionats amb aquest manteniment (HEGOA, 2005-2006). El projecte que proposa aquesta tesi no és una excepció i, en cas de desenvoluparse, hauria d'estar assegurada la seua sostenibilitat amb suficient personal per fer el seguiment adequat, amb el programari i el material necessaris per aconseguir-ho.

\subsubsection{Justícia social}

Per a l'ONU (s/d), la justícia social és un principi fonamental per a la convivència pròspera i pacífica dins dels països i entre ells, representa el nucli de la seua missió en la promoció del desenvolupament i la dignitat humana i es considera un 
principi subjacent per a la coexistència pacifica entre les nacions. Però, què s'ha d'entendre per justícia social? Pérez-Garzón (2019) explica l'evolució històrica del seu significat en quatre etapes:

1. Definició aristotèl-lica: Aristòtil distingia entre justícia universal (que comporta totes les virtuts) i justícia particular (decisions del món terrenal, polítiques i jurídiques), però no parla de les desigualtats socioeconòmiques.

2. Visió de Taparelli: a finals del segle XVIII, va transcendir la visió del jesuïta Luigi Taparelli d'Azeglio (Behr, 2003), que assumia la societat com una comunitat en la qual hi havia respecte per les persones, fomentava la caritat als pobres i li atorgava a l'Estat el paper de protegir l'ordre social, és a dir, protegir els obrers dels abusos dels poderosos però també protegir els poderosos del comunisme que promovien els obrers que es rebel-laven contra ells.

3. Drets obrers: de principis a mitjans del segle $\mathrm{XX}$, es comença a parlar de justícia social, dignitat humana i Estat Social de Dret, i es reclama un Estat de Dret compromés amb els valors de les revolucions liberals, però sempre garantint uns recursos mínims perquè les persones puguen viure amb dignitat.

4. Actualitat: hui dia, la justícia social està vinculada amb la igualtat d'oportunitats i s'entén que l'Estat té l'obligació de garantir-la.

Una vegada revisada l'evolució del significat de justícia social, partim del concepte actual per situar-lo al marc de la cooperació i el desenvolupament, ja que cada vegada es reconeix 
més la importància de considerar els projectes i polítiques de desenvolupament des de la perspectiva dels drets humans i la justícia social (Concha, 2003). La pobresa sempre fa referència a les carències 0 privacions de qualsevol classe que posen en perill la dignitat de les persones (HEGOA, 2005-2006) i, per tant, és incompatible amb la idea de justícia social, ja que impedeix la igualtat d'oportunitats entre els països i les persones.

És evident que les persones ancianes que pateixen discriminacions a São Tomé i Príncipe no tenen el seu benestar assegurat i tampoc la igualtat d'oportunitats respecte d'altres persones que no estan discriminades. Per aquest motiu, qualsevol projecte que busque la millora de les condicions en què viuen ha d'estar basat en aquest concepte de justícia social, que permetria una convivència pacífica entre les persones ancianes i la resta de veïnat. La proposta d'aquesta tesi busca donar visibilitat a aquest col-lectiu i oferir-li un nou rol a la societat com a font de coneixement. És evident que, només amb aquesta iniciativa, no s'aconseguirà pal-liar per complet les dificultats que viuen les persones ancianes, però suposaria una ferramenta alternativa que es pot sumar a altres iniciatives per tal d'aconseguir-ho.

\subsection{COOPERACIÓ I TRADUCCIÓ}

Des de les visions més tradicionals de la traducció i interpretació com a disciplina, se sustenta la idea que el traductor o l'intèrpret és neutral i no es posiciona a les interaccions en les quals participa (Baker, 2013). Potser a causa d'aquesta màxima, moltes de les activitats que la traducció i la interpretació desenvolupen en l'àmbit de la cooperació són passives i no suposen la involucració directa del traductor o l'intèrpret. És el cas d'ONG 
com Traducteurs sans frontières (fundada el 1993 a França), que accepta encàrrecs de traduccions que sol-liciten altres ONG verificades i que permet que s'estalvien el cost de les traduccions per poder dedicar eixos diners al treball de camp (Herrmann, 2012; Translators without borders, 2019).

No obstant això, també hi ha qui defensa una nova concepció de la professió des de la solidaritat, el compromís i l'ètica. Entre aquestes comunitats de traductors activistes, Baker (2013) en distingeix dos grups: aquells que es dediquen majoritàriament a la traducció i la difusió de contingut escrit a través de llistes de distribució de correu electrònic i pàgines web, i aquells que treballen a la comunitat $o$ en fòrums col-lectius $i$ interpreten intervencions orals en esdeveniments específics.

Com a exemple del primer grup, existeix Traduttori per la Pace, una organització italiana que, des de 2004, a més de difondre traduccions de textos que ells mateixos seleccionen, tenen l'objectiu de difondre la pau, especialment quan es tracta de conflictes militars, com la guerra de Kosovo (Baker, 2013; Camps, 2019; Traduttori per la Pace, s/d). Tlaxcala també formaria part d'aquest grup, encara que té un enfocament lleugerament diferent. Aquesta organització es va crear l'any 2005 per un grup de ciberactivistes que es coneixien a través d'internet $\mathrm{i}$ busca donar veu a textos escrits en llengües que no siguen l'anglès per trencar els padrons dominants tradicionals (Baker, 2013; Camps, 2019; Tlaxcala, s/d).

Al segon grup podem situar organitzacions com l'espanyola ECOS (fundada en 1998) o Babels, que va nàixer en 2002 de la mà d'activistes de diverses tendències i procedències. ECOS tradueix per a altres ONG o persones i col-lectius sense recursos, organitza xerrades de sensibilització sobre temes 
d'actualitat i col-labora en aquesta línia amb altres moviments socials (de Manuel et al., 2004). Per la seua banda, Babels pretén intervindre directament en l'agenda política i jugar un paper més rellevant als debats anticapitalistes cobrint les necessitats d'interpretació dels fòrums socials, ja que consideren que la traducció i la interpretació s'han convertit en un espai privilegiat per a l'acció política (Babels, s/d; Baker, 2013; Camps, 2019).

Com es pot veure, generalment, la traducció funciona a la cooperació de forma molt semblant a com ho fa al món laboral; sovint parteix d'un encàrrec i és depenent de textos 0 projectes desenvolupats per altres persones o organitzacions. No és habitual que la cooperació que es realitza des de l'àmbit de la traducció es desenvolupe independentment d'altres organitzacions ni directament al terreny quan es tracta de $\mathrm{Cl}$, a excepció d'alguna iniciativa de formació de traductors, com la que realitza Translators Without Borders (2019) a Kènia. En aquest cas, Translators Without Borders compta amb un centre d'aprenentatge a Nairobi on, des de 2012, forma persones en destreses relacionades amb la traducció. Després de rebre la formació, molts d'ells continuen treballant a l'ONG traduint en suahili i altres llengües de l'est d'Àfrica, a més de participar en èpoques de crisi (ja siga per epidèmies o per desastres naturals) en la traducció i la disseminació de materials per proporcionar informació actualitzada a la població que més ho necessita (Translators Without Borders, 2019).

Per la seua banda, Dollerup i OrelKos (2001) exposen la dificultat que tenen alguns països menuts de tindre una producció literària en les seues llengües, que són minoritàries. Aquest cas convida a reflexionar sobre una possible acció de la traducció literària. En aquesta línia, està el Proyecto Talis (2015), impulsat per un equip de docents i investigadors de la Universitat de València. Aquest projecte s'estructura en un grup 
d'investigació (Grupo de Investigación Talis) i la Asociación Proyecto Talis, l'objectiu de la qual és promoure l'educació intercultural i literària, la formació en valors, l'educació per a la ciutadania global i l'ensenyament de llengües a través de la docència, la investigació, l'edició de llibres i de materials educatius, la sensibilització i l'organització d'activitats culturals i d'oci educatiu. Proyecto Talis realitza tallers de contes en format bilingüe que posteriorment s'editen per convertir-los en material educatiu, ferramentes d'ensenyament $\mathrm{o}$ autoaprenentatge d'idiomes. Aquest procés està supervisat per experts traductors, filòlegs i pedagogs de l'associació. També hi participen estudiantat de Traducció, Filologia, Ciències de I'Educació, Magisteri, Cooperació al Desenvolupament o Professorat d'Educació Secundària. Amb els beneficis de la venda d'aquests contes, Proyecto Talis col-labora en projectes específics d'altres ONG (Proyecto Talis, s/d).

No obstant això, cal plantejar-se si açò és tot el que la traducció pot aportar a la CID o si és un camp de treball suficientment sòlid i de clara aplicació transversal com per anar més enllà i plantejar una participació més directa al terreny amb propostes relacionades amb la traducció en totes les seues variants, que puguen comportar beneficis col-laterals a una societat determinada, com és el cas que es presenta en aquesta tesi: evitar la desaparició del forro i dignificar els seus parlants (ancians) al mateix temps que es dignifica la llengua a través de la subtitulació. L'ús de la TAV suposaria una novetat, ja que es tracta d'una modalitat de traducció que sembla que no ha sigut explorada fins ara al camp de la CID, però seria igualment interessant fer un plantejament semblant des d'altres especialitats. Com assenyalen Dollerup i Orel-Kos (2001, p. 19):

It will become more evident that translation is crucial to international co-operation, as well as 
to the constitution of the national and cultural identity of communities and countries using minor languages $[\ldots]$.

\subsection{COOPERACIÓ I CINEMA}

Des dels inicis de la seua història, l'ésser humà ha utilitzat els relats per conéixer-se millor i transmetre els seus coneixements, valors i creences $i$, gràcies a ells, ha après com desenvolupar-se a la vida. Les normes bàsiques de comportament, per exemple, es concretaven amb les històries i narracions amb moralitat (Muñoz, 2007). El cinema no és més que l'evolució natural d'aquestes històries ancestrals, que transformen el seu format de la mateixa manera que ho fa la societat amb el pas del temps. Així, la capacitat del cinema per remoure consciències i crear un impacte en la societat és una nova representació d'aquelles històries ancestrals aplicades al nostre temps.

L'any 2016, el World Economic Forum publicava a la seua pàgina web un llistat de pel-lícules que, segons aquesta organització, havien impactat més la societat. El primer llargmetratge que apareix en aquesta llista, és $A$ Girl in the River. $A$ Price for Forgiveness (2015), de la directora Sharmeen Obaid Chinoy i coneguda a Espanya com Una chica en el río. El precio del perdón. Aquesta pel-lícula conta la història d'una jove pakistanesa que va sobreviure a un crim d'honor comès pel seu propi pare i un oncle per haver-se casat contra la voluntat de la família. Sharmeen Obaid Chinoy va guanyar l'Oscar al millor documental i, durant el seu discurs, va explicar que el primer ministre de Pakistan li havia dit que, després d'haver vist la pel-lícula, pensava canviar la llei sobre els crims d'honor (World Economic Forum, 2016). 
De fet, diferents associacions organitzen festivals de cinema de contingut social, com la Muestra de cine El Mundo y los Derechos Humanos, que se celebra anualment a Navarra (El cine, el mundo y los derechos humanos, s/d). L'any 2017-2018, I'AEXCID (Agencia Extremeña de Cooperación para el Desarrollo) va anar més enllà d'un festival de cine i, durant el Festival de Cine de Mérida, a més de projectar pel-lícules relacionades amb la cooperació i el desenvolupament, va realitzar tallers de formació de producció i divulgació de material audiovisual per a ONG, així com altres tallers relacionats amb el cinema i la cooperació dirigits a xiquets i joves (Festival Cine Mérida, 2017).

L'any 2016, l'AECID, que també aposta per la utilització del cine en la mateixa línia que l'AEXCID, va participar a la 64a edició del Festival de cine de Sant Sebastià amb la sessió Cine, Desarrollo y Sostenibilidad. La proposta de l'AECID en aquest cas, va estar constituïda per tres projectes que incloïen l'edició del llibre Mujeres de cine (Fontaneda, 2015), al qual s'il-lustra la influència de les grans produccions de Hollywood dels anys 20 i 30 a Espanya i de quina manera van afectar les dones espanyoles d'aquella època; la projecció de la pel-lícula documental Nómadas (Martínez, 2016) sobre una comunitat de pastors nòmades de Mali; i una xerrada que plantejava de quina manera pot contribuir el cinema a complir amb els 17 ODS (v. 4.1). A més, cal recordar l'existència del Premio Cooperación Española al Festival de Sant Sebastià, que premia aquelles pel-lícules iberoamericanes que millor contribueixen a difondre els ODS, l'erradicació de la pobresa i els drets humans (AECID, 2016).

El potencial del cinema per generar consciència és, doncs, innegable, i és natural que s'utilitze per a educar en valors, com defensen Fernández i López (2014). Aquests autors mantenen que el cinema és un suport important en l'educació 
i especifiquen de quina manera ajuda a formar l'estudiantat per competències educatives. Per la relació amb aquesta tesi, ens centrem a continuació en les competències ètiques, lingüístiques i culturals que mencionen aquests autors.

Primerament, el cinema activa la capacitat crítica i reflexiva i promou un judici moral sobre aspectes rellevants de la vida, que de vegades pot presentar amb gran impacte (Fernández i López, 2014). Va ser el cas, per exemple, del documental Blackfish (Gabriela Cowperthwaite, 2013), que va obrir el debat sobre la moralitat dels espectacles d'orques en captivitat. Després del llançament d'aquest documental, el nombre de visitants que rebia el parc Sea World, del qual es parla al documental, va disminuir dràsticament fins que el parc va haver de cancel-lar l'espectacle tradicional amb orques i substituir-lo per un altre que se centrava més en el seu comportament natural (World Economic Forum, 2016).

El cinema representa també el llenguatge verbal i el no verbal i reprodueix escenaris comunicatius de la vida real. Permet, per tant, aprendre a expressar-se, escoltar i entendre, és a dir, que també pot considerar-se una ferramenta útil en l'ensenyament lingüístic, ja que es tracta d'un instrument de comunicació que convida a expressar pensaments, emocions, vivències $\mathrm{i}$ opinions, a dialogar, generar idees, donar coherència $i$ cohesió als discursos i fins i tot aprendre llengües, com promou l'associació FILTA (Herrero et al., 2013). Pel que fa a l'àmbit cultural, com expliquen Fernández i López (2014), el cinema ajuda a comprendre diferents realitats, perquè suposa conéixer, comprendre i valorar diferents manifestacions culturals, utilitzar-les com a font d'enriquiment i considerar-les part del patrimoni dels pobles, a més de contribuir a la comprensió crítica de la realitat històrica i social del món. En definitiva, i segons aquests autors, el cinema pot incorporar- 
se al sistema educatiu com a eina didàctica i també com a objecte d'estudi de la manera següent (Fernández i López, 2014, s/p):

1. Ciències Socials, Història i Geografia: cine històric, biografies, fets històrics rellevants, documentals, anàlisis sobre evolucions de comportaments, costums, conductes, etc.

2. Llengua: es pot analitzar l'argument, el text, el llenguatge oral i escrit de la pel-lícula. També es poden utilitzar pel-lícules en format de teatre, en vers, biografies de personatges literaris, adaptacions d'obres literàries, etc.

3. Llengua estrangera: qualsevol pel-lícula en versió original amb subtítols és, com s'ha vist en l'apartat 2.3, un bon mètode per aprendre idiomes.

4. Ciències Naturals: cine amb temàtiques de naturalesa, medi ambient, sostenibilitat, antropologia, etc.

5. Matemàtiques: si s'utilitza el cine com a objecte d'estudi, es pot estudiar la creació d'una pel-lícula des del punt de vista dels costos, el finançament, el càlcul de riscos, la rendibilitat, etc.

6. Música: totes les bandes sonores i la seua capacitat per provocar sensacions i atmosferes d'identificació són un gran camp d'estudi en aquesta assignatura, especialment quan es tracta de musicals o biografies de grans músics.

7. Tecnologia i Plàstica: aquestes matèries són pròximes al cine com a objecte d'estudi. Poden analitzar-se les tècniques de filmació, la llum, la composició, el muntatge, etc. 
8. Ėtica, Filosofia, etc.: l'ús del cine en aquestes matèries va dirigit a activar la capacitat crítica i reflexiva de l'alumnat; oxigena la seua consciència i promou un judici moral sobre aspectes rellevants de la vida.

Santos i Romero (2016) defensen la inclusió de materials audiovisuals al currículum escolar amb l'objectiu de portar l'ED a les aules (v. 4.2.1.1). Consideren l'ED una ferramenta fonamental per contribuir als canvis socials i el cinema, una bona manera de tractar aquests temes, ja que desperta la sensibilitat crítica i la participació activa. Aquests autors assenyalen, a més, que en una societat on ens «bombardegen» amb imatges i la tendència és fer espectacles de les tragèdies que ocorren al món, es pot caure en la insensibilització front a les notícies i les imatges violentes que observem (p. 18). En aquest context, és important ajudar els alumnes a interpretar els continguts audiovisuals i educar-los per a ser espectadors crítics amb la realitat, que puguen comprendre el món a través del cinema i prendre una posició activa front a problemàtiques que afecten tota la societat. Santos i Romero (2016) coincideixen, per tant, amb Fernández i López (2014) a pensar que utilitzar el cinema com una ferramenta didàctica és important per a l'educació de l'alumnat, tant pel que fa a la formació en les matèries del currículum escolar, com a la formació personal que els ha de preparar per a enfrontar el seu dia a dia, amb les problemàtiques del seu entorn.

De fet, el cinema i l'ED van de la mà fins i tot en la formació en cinematografia com a camp d'estudi. És el cas de Yangon Film School (YFS), una ONG amb seu a Berlín que treballa a Myanmar des de l'any 2005 i que, front a la falta d'oportunitats educatives que ofereix el país, es dedica a formar joves en matèries relacionades amb el sector audiovisual, no només per donar una oportunitat de futur i una professió a la joventut d'aquest país, sinó 
també per desenvolupar la indústria cinematogràfica a Myanmar (YFS, 2019).

YFS no és l'únic cas: La Poderosa, amb seu a Quito, per exemple, treballa des de l'any 2004 a Amèrica Llatina i als Estats Units, també en formació cinematogràfica de joves. La diferència entre aquesta organització i YFS és que La Poderosa no se centra tant en la formació de futurs cinematògrafs o professionals del sector audiovisual, sinó en l'apoderament dels joves i el foment de l'empatia cultural i el treball en equip mitjançant un aprenentatge col-laboratiu (La Poderosa, 2015). A la seua pàgina web, diuen:

We believe that self-representation, creativity, and collaboration empower youth to be active participants in their environments. We envision a future in which young leaders think differently, communicate productively, and inspire others to effect change. La Poderosa Media Project works with youth so that their ideas, their stories, their lives make a difference in shaping the future.

Un altre exemple del confluir del cinema i la cooperació seria el de Kibera Girls Soccer Academy a Kènia, una escola femenina situada en un barri de barracons que es va crear amb l'objectiu d'oferir a les xiquetes oportunitats d'educació, seguretat i alimentació gratuïtes. Després de rebre un taller formatiu sobre cinema, algunes de les xiques van crear una empresa de gravació i fotografia amb l'objectiu d'intentar canviar els aspectes negatius de l'entorn on viuen (Kibera Girls Soccer Academy, 2012; Romero Fresco, 2013).

A Espanya, la fundació Tus Ojos (2014) pretén realitzar un cinema que mostre la realitat social per acostar-la 
a l'espectador i generar reflexió, sensibilització i actituds constructives. Abraça diverses temàtiques (immigració, interculturalitat, igualtat de gènere, cooperació i solidaritat internacional, etc.) i intenta treballar en favor dels ODS. A banda de promoure la distribució de material audiovisual que seguisca les màximes anomenades, Tus Ojos també organitza exposicions itinerants on es projecten alguns dels seus treballs en un marc d'activitats de sensibilització transversals, elabora guies didàctiques i ferramentes educatives per al desenvolupament de projectes d'alfabetització visual i educació en valors, i col-labora amb institucions públiques i privades en projectes sense ànim de lucre per fomentar activitats d'interès social (Tus Ojos, s/d).

Per últim, cal assenyalar l'activitat del col-lectiu Cine sin Autor (CsA) amb seu a Madrid, que des de 2007 tracta de generar processos col-lectius d'aprenentatge participatiu i horitzontal, on es produeix un intercanvi igualitari de coneixements entre els participants. Aquesta proposta és en realitat un model audiovisual d'integració i mediació amb components d'alfabetització social i audiovisual: els agents que hi participen s'impliquen de forma dialògica i inclusiva per transcendir la seua condició d'espectadors i passar a ser autors del seu imaginari fílmic, amb temàtiques que els resulten pròximes (Sedeño, 2015).

São Tomé i Príncipe també ha sigut escenari de diferents iniciatives cinematogràfiques, com ara els documentals Fitxicêlu. Crenças, Estigma e Ostracismo (Lima i Soares, 2016) que parla sobre les acusacions de fetilleria a persones ancianes; Serviçais das Memorias à Identidade (Medeiros, 2017) sobre els

\footnotetext{
${ }^{6}$ www.cinesinautor.es
} 
capverdians que van treballar a les plantacions (v. 5); O canto do Ossobó (Tiny, 2018) sobre una de les antigues plantacions del país a ulls del director del documental, que torna al seu país d'origen després de 30 anys; o el projecte cultural Aguêdê-Alê (Aguêdê-Alê, 2020), que incloïa la projecció de curtmetratges que representaven històries sobre les plantes medicinals del país i la creació d'un llistat d'aquestes plantes en el seu nom científic, portuguès, forro i lung'ie, on trobar-les i per a què s'utilitzen (v. 5.2).

El cinema ha evolucionat la seua implicació en la societat des de fer pel-lícules de denúncia o de realitat social com $A$ Girl in the River o Blackfish, a oferir formació (YFS) o ser ferramenta d'integració social (CsA). Podem dir, per tant, que l'activisme, la cooperació i el cinema van de la mà en moltes ocasions i que, amb el pas del temps, sorgeixen noves perspectives per donar al setè art una funció alternativa dins el cooperativisme, de la mateixa manera que aquesta tesi proposa una funció alternativa per a la TAV. El cinema podria ser una important contribució al cas de la revitalització del forro i la integració d'ancians a São Tomé i Príncipe per l'impacte, l'entreteniment, l'empatia, la diversió i l'aprenentatge que podrien generar les imatges que es subtitulen.

En definitiva i com a resum d'aquest capítol, des de la creació del Pla Marshall el 1949 i el consegüent sorgiment d'organismes com l'ONU, el BM, I'FMI, l'OCDE i el CAD comença a establir-se a la societat la idea de la $\mathrm{Cl}$ que comporta la creació dels ODM l'any 2000. Aquests objectius es perfeccionen i amplien l'any 2015, i passen a denominar-se ODS. Les reflexions a partir de les experiències de $\mathrm{Cl}$ condueixen a crear nous conceptes que s'engloben dins d'aquesta activitat, per exemple, la sostenibilitat i la justícia social, indispensables per al bon funcionament i continuïtat dels projectes, i la $C D$, que es diferencia de la $\mathrm{Cl}$ perquè incorpora el concepte de desenvolupament. Cal tindre present que CD no és 
sinònim d'ajuda internacional, ja que aquesta suposa únicament una transferència de recursos. El següent mapa conceptual il-lustra aquesta recapitulació:

II-Iustració 2. Esquema dels conceptes de cooperació.

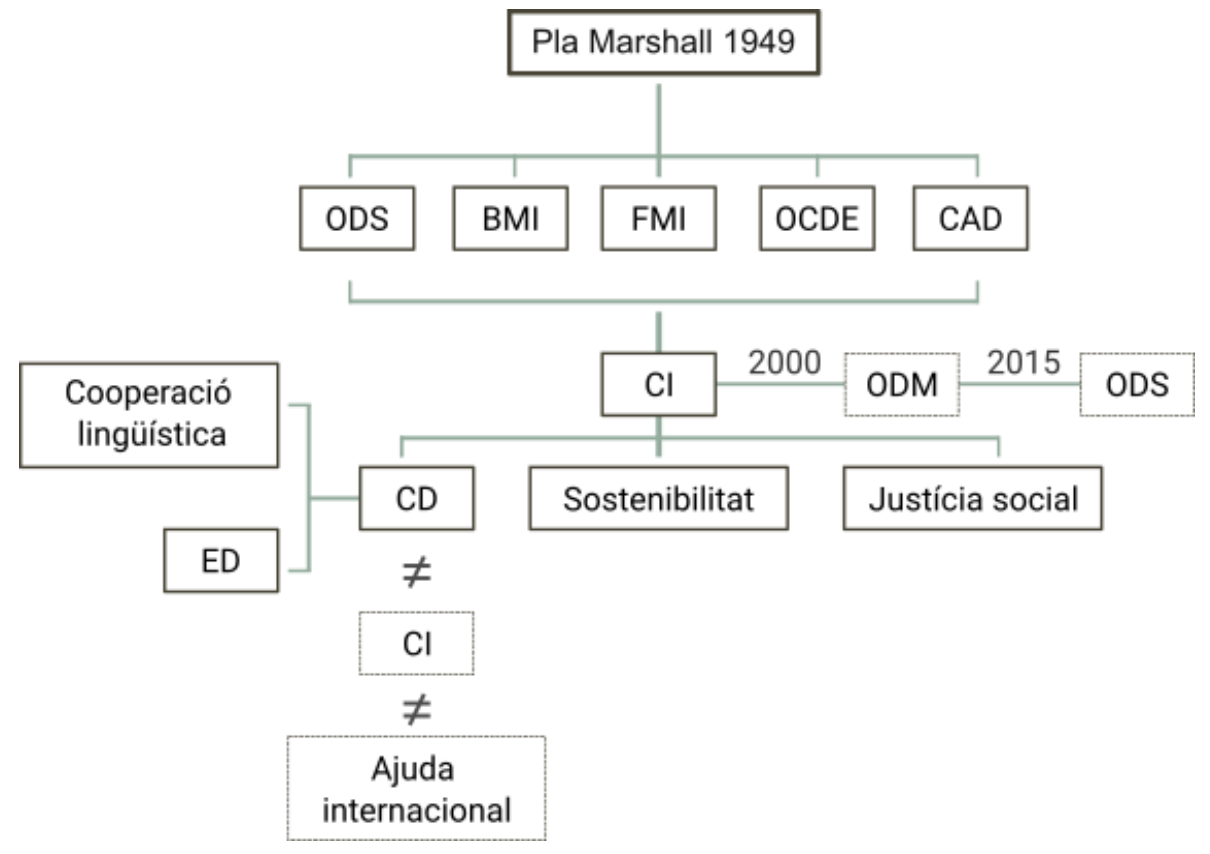

Amb el pas del temps, distints camps de treball s'incorporen a les activitats relacionades amb el desenvolupament i aporten noves formes d'entendre la cooperació. En aquest capítol hem vist els exemples de la traducció i el cinema, no obstant això, aquesta tesi proposa anar més enllà i oferir una nova visió en què s'integre la TAV com a eina activa per a realitzar projectes de CID. Aquesta opció no s'ha contemplat fins ara i aportaria noves possibilitats als projectes que es realitzen actualment. 


\section{SÃO TOMÉ I PRÍNCIPE}

Aquest capítol se centra en donar una visió general del país al qual s'emmarca la present investigació. Encara que se situa abans d'entrar a detallar la metodologia del treball, es considera part dels resultats, ja que ha sigut necessari realitzar una investigació sobre el context històric, cultural, social i lingüístic del país i aquest afecta inevitablement a la metodologia i a la manera d'enfocar les conclusions. A continuació, per tant, s'expliquen el context històric de São Tomé i Príncipe, la situació de les llengües del país, l'estat del sistema educatiu i les necessitats de cooperació en aquest territori.

\subsection{CONTEXT HISTÒRIC DE SÃO TOMÉ I PRÍNCIPE}

São Tomé i Príncipe és un país format per diverses illes situat al golf de Guinea, molt a prop de la línia equatorial. Té una superfície de $1.001 \mathrm{~km}^{2} \mathrm{i}$ una població de 194.000 habitants segons el Banc Africà de Desenvolupament (AFDB, 2016), encara que a finals de 2020 el periòdic Téla Nón va publicar que els mesuraments més recents indiquen unes dimensions de $991 \mathrm{~km}^{2} \mathrm{i}$ una població de 200.000 habitants $^{7}$ (Veiga, 2020).

\footnotetext{
${ }^{7}$ No s'ha pogut accedir a l'estudi que indica aquestes
} noves dades. 
Sembla que la història humana del país va començar amb el descobriment de les illes pels portuguesos l'any 1471 i amb la seua colonització (São Tomé el 1493 i Príncipe el 1500), ja que es pensa que les illes estaven deshabitades (Seibert, 2009; Agostinho i Bandeira, 2017). L'economia depenia de la canya de sucre, que necessitava la mà d'obra dels esclaus que portaven del delta del Níger, Congo i Angola (Hagemeijer, 2009; Lorenzino, 1996). A més, des del seu poblament, São Tomé i Príncipe va ser un punt neuràlgic per al negoci de tràfic d'esclaus; des d'allà els transportaven primer a l'actual Ghana i, més endavant, també a Amèrica (Seibert, 2009).

A causa de les malalties tropicals, la mortalitat dels europeus era molt elevada i, per garantir-ne la població, Portugal va incentivar les unions entre homes blancs i esclaves africanes (Seibert, 2009). L'any 1515, mitjançant la carta de alforria, el rei va declarar lliures aquestes africanes i els seus fills mestissos i, dos anys més tard, també els primers esclaus que havien arribat amb els colons portuguesos (Hagemeijer, 2009; Seibert, 2009).

A mitjans del segle XVII els plantadors de sucre es van traslladar a Brasil, on tenien millors perspectives de negoci. A més, cada vegada eren més les amenaces d'atacs de corsaris francesos, anglesos i holandesos i els assalts a les plantacions per part d'esclaus fugitius, que s'havien refugiat a l'interior inaccessible de São Tomé. Així doncs, els portuguesos se'n van anar a Brasil i l'illa va quedar en mans dels forros (els alliberats mitjançant la carta de alforria) que vivien amb una economia de subsistència. Al segle XIX, però, l'arribada del cafè i el cacau de Brasil de mà dels portuguesos va comportar un renaixement de l'economia de plantació i una segona colonització, que va tindre com 
a conseqüència la marginació dels forros, que van perdre els seus territoris gradualment (Seibert, 2009).

L'any 1869 es va abolir l'esclavitud i l'estratègia dels colonitzadors front a la falta de mà d'obra va ser implementar el règim de contractats, que consistia a portar treballadors d'Angola, Cap Verd, Moçambic i, encara que més efímerament, també de Macau i de l'Índia (coolies), i confinar-los al treball de les plantacions, completament segregats dels forros que, per la seua banda, rebutjaven treballar-hi per identificar-ho com un treball d'esclaus i considerar que era inferior a la seua condició d'africans Iliures (Agostinho i Bandeira, 2017; Nascimento, 2004; Seibert, 2009). Tot i que ja s'havien esdevingut diferents protestes durant els 500 anys d'ocupació portuguesa, cap d'elles va ser exitosa per la falta d'organització dels participants (Ribeiro de Souza, 2015). Però, quan l'any 1953 van arribar notícies que el governador volia obligar els forros a treballar a les plantacions, va esclatar una revolta a la qual aquest va respondre de forma repressiva, desmesurada i sagnant: la massacre de Batepá (Gonçalves de Género, 2012; Nascimento, 2001; Seibert, 2009). Es desconeix la quantitat de morts que va resultar d'aquesta massacre; alguns tirotejats, d'altres cremats, alguns asfixiats per haver estat tancats dins d'una cel·la massa xicoteta per a la quantitat de presos que hi havia. Encara a altres se'ls va castigar a «buidar l'aigua del mar» (Seibert, 1997, p. 182), o se'ls va interrogar sota diferents tortures per obligar-los a confessar un delicte inexistent. Evidentment, un fet tan dramàtic com aquest va marcar per sempre la història de São Tomé i Príncipe i va ser decisiu per encoratjar els primers moviments per aconseguir la llibertat del país (Gonçalves de Género, 2012; Marky, 1963; Nascimento, 2001; Seibert, 1997 i 2009).

La independència de Portugal l'any 1975 va portar la llibertat al país, però també la incertesa de com consolidar 
un patrimoni social i cultural anul-lat durant centenes d'anys (Ribeiro de Souza, 2015). Es va implantar una dictadura que va durar 15 anys, després va arribar la democràcia, però ni un model ni l'altre van aconseguir impulsar el país com s'esperava. Com que els africans tenien l'accés restringit a nivells d'ensenyament superior durant el colonialisme, molts dels forros que van ocupar llocs de treball en l'administració pública i la gestió de plantacions no tenien suficient preparació ni experiència, mentre que els contractats no van tindre més opcions que quedar-se a les plantacions. Pocs anys després de la independència, es va fer evident que no tenien ni capacitat ni mitjans perquè les mesures que es prenien donaren resultat, i el nou model democratitzador, que també es va caracteritzar per una considerable inestabilitat, va ser incapaç de transformar el país (Caballero i Metzger, 2007; Pantoja, 2008; Seibert, 2009).

A causa de diversos factors, com ara la inestabilitat política, així com la falta de mesures contundents i eficients que tallen aquest problema, el país ha constatat un increment de la pobresa des de l'any 1900 (Caballero i Metzger, 2007), que ha continuat fins a l'actualitat. El Terceiro Relatório Nacional dos Objectivos do Milénio de l'any 2014 indica una taxa de pobresa del $71,3 \%$ per a les dones i d'un 63,4\% per als homes i, quant al desenvolupament humà, São Tomé i Príncipe ocupa el lloc 127 en un Ilistat de 175 països (Gonçalves de Género, 2012; Terceiro Relatório Nacional dos Objectivos do Milénio, 2014).

\subsection{LES LLENGÜES DE SÃo TOMÉ I PRÍNCIPE}

São Tomé i Príncipe és un país multilingüe. $A$ banda del portuguès, que actua com a llengua oficial i exclusiva a 
tots els efectes (Hagemeijer, 2019), també s'hi parla lung'ie a l'illa de Príncipe i angolar, capverdià i forro a l'illa de São Tomé. A més, encara es conserva el portuguès tonga, nascut del contacte entre el portuguès que es parlava a les antigues plantacions de cafè i cacau i les llengües bantu que parlaven els descendents d'esclaus de la segona colonització procedents d'Angola i Moçambic (Araujo i Agostinho, 2010; Gonçalves i Hagemeijer, 2015; Hagemeijer, 2009; Lorenzino, 1996).

Durant la primera colonització d'aquestes terres per part dels portuguesos i els primers esclaus procedents del delta del Níger, Congo i Angola, va sorgir en São Tomé un primer pidgin que es convertiria, degut a la seua ràpida expansió, en allò que hui es coneix com a crioll forro, santomé o dialecto, fruit del contacte entre les llengües dels esclaus i del portuguès dels colonitzadors (Gonçalves i Hagemeijer, 2015; Hagemeijer, 2009 i 2018). A l'illa de Príncipe, el desenvolupament d'aquest pidgin per part dels esclaus que hi van portar va desembocar en la formació del lung'ie (Agostinho i Bandeira, 2017).

La segona colonització, en què els portuguesos van tornar de Brasil, va suposar una profunda alteració lingüística. Per una banda, es van portar més treballadors de Cap Verd, Angola i Moçambic majoritàriament, però també del Benín, Gabó, Serra Lleona i Libèria, la qual cosa va contribuir a incrementar el multilingüisme del país (Hagemeijer, 2019); per l'altra banda, el portuguès va interrompre el predomini dels criolls $i$ es va convertir en llengua dominant (Gonçalves i Hagemeijer, 2015). De fet, parlar portuguès era una de les condicions per aconseguir algun privilegi administratiu o social. Les llengües criolles no tenien cap valor $i$, encara que no van desaparèixer del tot, s'utilitzaven molt rarament per por del càstig. (Ribeiro de Souza, 2015). Com diu Mata (2004, pp. 53-54): 
Famílias havia que proibiam os seus filhos de se expressarem em crioulo, tentando, deste modo tosco e alienante, prevenir a ascensão na sociedade colonial. Não admira que muitos da elite são-tomense não soubessem - e não saibam! - falar a língua do país, o mais emblemático marcador da identidade sãotomense.

A principi del segle $\mathrm{XX}$, una epidèmia de tripanosomosi africana (malaltia de la son) va exterminar gran part dels esclaus que treballaven a Príncipe. Com a conseqüència, hi van portar altres treballadors parlants de capverdià (Agostinho i Bandeira, 2017). El capverdià es parla extensament a l'illa de Príncipe, no només per aquest motiu, sinó perquè, després de la independència, la majoria de capverdians s'hi va quedar en lloc de tornar al seu país (Gonçalves i Hagemeijer, 2015; Ribeiro de Souza, 2015).

Quan São Tomé i Príncipe va aconseguir la independència, el portuguès es va refermar com a llengua oficial exclusiva en l'educació i en tots els contextos comunicatius. Així, l'estigmatització i la ideologia lingüística lligada als criolls, herència de l'època colonial, no es va superar i açò ha impedit una identitat criolla lligada a les seues llengües i una disminució de certs elements d'identitat de tipus cultural, religiós, etc. (Gonçalves i Hagemeijer, 2015; Ribeiro de Souza, 2015). Tornant als conceptes de McCarthy (2018) (v. 1.4) per comprendre millor la planificació lingüística que va esdevenir a São Tomé i Príncipe, es pot veure que l'status planning que es va determinar va ser impulsar únicament el portuguès a les administracions, les escoles i els mitjans de comunicació; no es va desenvolupar cap corpus planning (com materials d'ensenyament, vocabularis, etc.), i els programes 
educatius també es van preparar pensant únicament en l'adquisició del portuguès (acquisition planning). Com a resultat d'aquesta planificació lingüística, que només contempla l'ús i l'aprenentatge del portuguès, es poden trobar testimonis com els que recull Laban (2002) en diferents entrevistes a escriptors del país, a les quals expliquen que els vells parlaven forro i als més joves se'ls obligava a parlar portuguès, fins $i$ tot es denigrava les persones que utilitzaven aquesta llengua, que es qualificava de «llengua de gos» (p. 75) o «llengua de micos» (p. 386).

Durant anys, doncs, els diversos parlars criolls van ser relegats a l'estatus de llengua dels pobres i analfabets (iconization, v. 1.2) i no es permetia que els xiquets els utilitzaren per por que afectara la seua correcta adquisició del portuguès (Bouchard, 2017). Tots aquests esdeveniments sociohistòrics han fet que São Tomé i Príncipe siga l'excolònia portuguesa d'Àfrica amb més parlants natius de portuguès, i constitueix un cas únic a Àfrica, on el nombre de parlants natius de les llengües colonials sol ser baix (Hagemeijer, 2018).

A partir de l'any 2010, però, es van fer tres avanços importants, que es corresponen amb el corpus planning de les activitats que proposa McCarty (2018) per a que es desenvolupe una planificació lingüística (v. 1.4): una comissió formada per acadèmics i intel lectuals va crear l'ALUSTP (Alfabeto Unificado para as Línguas Nativas de São Tomé e Príncipe) per a representar alfabèticament el forro, l'angolar i el lung'ie (Agostinho i Bandeira, 2017; Araujo i Agostinho, 2010), el primer diccionari portuguèsforro/forro-portuguès l'any 2013 (Araujo i Hagemeijer, 2013) i, el 2014, The Gulf of Guinea Creole Corpora (Hagemeijer et al., 2014). Tot i això, en l'actualitat els criolls són llengües que només s'utilitzen en l'àmbit privat i no tenen cap suport institucional. De fet, a la constitució del país ni tan sols s'esmenta la seua realitat lingüística 
(Gouveia, 1993). Les llengües criolles no s'estudien en cap nivell d'ensenyament, ni tan sols des de la perspectiva de la seua interacció amb el portuguès (Hagemeijer et al., 2018), és a dir, no existeix cap acquisition planning (v. 1.4). Actualment, la majoria de persones que utilitzen els criolls són persones majors (Gonçalves $i$ Hagemeijer, 2015; Ribeiro de Souza, 2015).

A continuació es mostren els resultats del cens realitzat per l'Institut Nacional d'Estadística de São Tomé i Príncipe l'any 2012 sobre el percentatge de parlants per llengua al país. A la taula 3 es mostra l'evolució de la quantitat de parlants des de l'any 1981 fins el 2012; a la taula 4, l'edat dels parlants de cada llengua. La pregunta que se'ls va fer als enquestats és Quais línguas que o(a) Sr(a) fala? (Bouchard, 2017; Hagemeijer, 2018).

Taula 3. Percentatge de parlants per llengua en l'era post-colonial a São Tomé i Príncipe (1981-2012). (Adaptada de Bouchard, 2017 i Hagemeijer, 2018).

PERCENTATGE DE PARLANTS PER LLENGUA EN L'ERA POST-COLONIAL A SÃO TOMÉ I PRÍNCIPE (1981-2012)

\begin{tabular}{lrrrrrr}
\hline ANYS & $\begin{array}{c}\text { POBLACIÓ } \\
\text { TOTAL }\end{array}$ & PORTUGUĖS & FORRO & LUNG'IE & ANGOLAR & CAPVERDIÀ \\
\hline 1981 & 96661 & $62,6 \%$ & $56,3 \%$ & $1,6 \%$ & - & - \\
\hline 1991 & 117504 & $80,8 \%$ & $59,5 \%$ & $1,3 \%$ & - & - \\
2001 & 137599 & $99,3 \%$ & $72,4 \%$ & $2,4 \%$ & - & - \\
\hline 2012 & 173015 & $98,4 \%$ & $36,2 \%$ & $1,0 \%$ & $6,6 \%$ & $8,5 \%$ \\
\hline
\end{tabular}


Taula 4. Percentatge de parlants per llengua segons edats (2012). (Adaptada de Bouchard, 2017).

\begin{tabular}{|c|c|c|c|c|c|}
\hline \multicolumn{6}{|c|}{ PERCENTATGE DE PARLANTS PER LLENGUA SEGONS EDATS (2012) } \\
\hline EDAT & PORTUGUĖS & FORRO & LUNG'IE & ANGOLAR & CAPVERDIÀ \\
\hline $5-9$ & $99 \%$ & $9 \%$ & $0,1 \%$ & $1,9 \%$ & $2,7 \%$ \\
\hline $10-19$ & $99,8 \%$ & $25,8 \%$ & $0,4 \%$ & $4,4 \%$ & $5,6 \%$ \\
\hline $20-29$ & $99,7 \%$ & $43,7 \%$ & $1,2 \%$ & $8,0 \%$ & $11,4 \%$ \\
\hline $30-39$ & $99,6 \%$ & $56,2 \%$ & $1,7 \%$ & $10,3 \%$ & $13,8 \%$ \\
\hline $40-49$ & $99,3 \%$ & $63,3 \%$ & $2,5 \%$ & $11,4 \%$ & $16,0 \%$ \\
\hline $50+$ & $97,8 \%$ & $73,4 \%$ & $2,7 \%$ & $13,8 \%$ & $14,2 \%$ \\
\hline
\end{tabular}

Encara que al cens no es distingeix entre L1 i L2 ni es proporciona informació sobre bilingüisme o plurilingüisme (Bouchard, 2017; Hagemeijer, 2018), és evident el detriment de les llengües criolles respecte al portuguès. A la taula 3 , pot apreciar-se clarament que les llengües criolles les parlen majoritàriament les persones de més edat.

Segons Hagemeijer (2018, p. 178), el resultat de l'any 2001 a la taula 3 sembla dubtós per la diferència de parlants de forro de quasi un 13\% entre els anys 1991 i 2001 comparada amb la caiguda del 50\% entre els anys 2001 i 2012. Assenyala que també resulta confús el resultat del lung'ie de l'any 2012, ja que altres investigadors han estimat que el número de parlants d'aquesta llengua varia entre 20-30 i 200 parlants (p. 180). Hagemeijer pensa que aquest resultat pot deure's al fet que les 
respostes d'alguns enquestats podrien tindre més a veure amb l'actitud que tenen envers la llengua que amb l'ús real que en fan. Cal assenyalar que no es van obtindre dades de l'angolar i el capverdià (tercera llengua més parlada l'últim any) fins el 2012. Per últim, s'ha de tindre en compte que la resposta de cada enquestat dependrà de la noció subjectiva que cadascun tinga sobre què és parlar una llengua.

En contrast amb aquesta tendència, Bouchard (2017) observa un interès creixent pels criolls com a part de la identitat nacional, en part per persones que van haver d'emigrar, però també per part de diferents lingüistes, que aporten gramàtiques, diccionaris i diferents estudis sobre les llengües de São Tomé i Príncipe.

\subsubsection{Els criolls a l'illa de São Tomé en l'actualitat}

Com s'ha explicat anteriorment, a l'illa de São Tomé es parlen tres llengües criolles: l'angolar, el capverdià i el forro. No ens detindrem a continuació en el portuguès de São Tomé, ja que els estudis publicats (Bouchard, 2017; Gonçalves i Hagermeijer, 2015) se centren més en l'aspecte lèxic i dialectal de la llengua, àmbits que queden fora de l'abast d'aquesta tesi.

\subsubsection{Angolar}

Existeixen dues teories sobre l'origen de l'ètnia angolar. Per una banda, hi ha una teoria, encara que difícil de comprovar, segons la qual, al segle XVI, un vaixell negrer d'Angola va naufragar a la costa oriental. Els supervivents es van refugiar a la selva i van viure aïllats dels colons durant 30 anys (Castaño, 2012). L'altra teoria, recolzada per més investigadors, afirma que els 
angolars eren esclaus que treballaven a les plantacions i es van escapar per refugiar-se a l'interior de l'illa (Araujo i Agostinho, 2010; Castaño, 2012; Hagemeijer, 2013; Lorenzino, 1996).

La literatura escrita en llengua angolar es redueix a alguns contes, històries, proverbis i endevinalles (Cardoso et al., 2015). En l'actualitat es parla sobretot al districte de Caué, al sud de l'illa (Araujo i Agostinho, 2010; Castaño, 2012). Quant a la percepció lingüística dels parlants d'angolar, Bouchard (2017, p. 195) diu:

[...] my experience with Angolares showed that they view their creole positively, even more positively than Forros do toward their own creole, and they do use it more frequently, in a wider range of social environments

\subsubsection{Capverdià}

Encara que actualment no existeixen estudis sobre les particularitats del capverdià de São Tomé i Príncipe (Bouchard, 2017; Hagemeijer, 2009), a la taula 4 es veu que es tracta de la tercera llengua més parlada per darrere del portuguès i el forro, dada que s'explica per motius històrics.

Els contractats que van arribar a l'illa durant la segona colonització van superar la població autòctona i, a més a més, van contribuir a que la diversitat lingüística del país fora major (Nascimento, 2000). Entre les llengües que van arribar en aquell període, només el capverdià es manté. Açò es deu al baix índex de repatriaments de capverdians $i$ dels seus descendents i a l'estreta relació que existeix entre la identitat capverdiana i el seu crioll 
(Hagemeijer et al., 2018; Hagemeijer, 2016). A més, els capverdians eren molts i sovint arribaven acompanyats per les seues famílies, la qual cosa va facilitar l'ús i la preservació de la llengua tant a São Tomé com a Príncipe (Bouchard, 2017). En conseqüència, en l'actualitat hi ha milers de parlants de capverdià, especialment a les antigues plantacions o en zones rurals aïllades (Castaño, 2012).

\subsubsection{Forro}

El crioll forro va nàixer amb l'arribada d'esclaus de diferents parts d'Àfrica, com una barreja de les seues llengües i el portuguès dels colons (Hagemeijer, 2009). No és difícil imaginar que, amb aquest context, la diglòssia estaria definida pràcticament des del naixement del forro i els seus parlants, estigmatitzats pels seus orígens. Aquesta diglòssia es veu accentuada per l'absència de llengües criolles en l'àmbit educatiu i administratiu; els comunicats i les intervencions del Govern són sempre en portuguès i aquesta també és la llengua comuna als mitjans de comunicació (Hagemeijer, 2009). Pot haver-hi alguna presència del crioll forro, però si la comparem amb la del portuguès, resulta anecdòtica.

Pel que fa a la tradició escrita en forro, existeixen diverses publicacions, però generalment es tracta de reculls d'endevinalles, proverbis, poemes, cançons, històries curtes o textos lligats a alguna manifestació cultural del país (Cardoso et al., 2015). Certament, el forro té lligams forts amb els proverbis, les músiques i moltes tradicions del país. Per exemple, hi ha el cas del tlundu, el carnestoltes nacional, que cada vegada es veu menys per la influència del carnestoltes brasiler. Antigament, diferents grups de tlundu recorrien els barris i les comunitats durant els tres dies de 
carnestoltes, i difonien missatges de crítica social en clau de comèdia i moralitat en forro (Castaño, 2012; Veiga, 2019).

En l'actualitat, són els residents de les zones més agrícoles i, sobretot, els més majors qui mantenen el forro com a llengua habitual (Gonçalves i Hagemeijer, 2015; Mata, 2004; Ribeiro de Souza, 2015). No obstant això, Bouchard (2017) assenyala que moltes persones han après forro estant a l'estranger $\mathrm{i}$ l'utilitzen com a marca d'identitat, ja que consideren que el forro és una ferramenta d'unió i que els distingeix d'altres parlants de portuguès. Aquesta autora també observa un major interès pel forro als mitjans de comunicació i en la producció musical, així com un desig de mesures per preservar la llengua i introduir-la en l'ensenyament, encara que no especifica iniciatives concretes. Tot i que no ha sigut possible trobar documents que ho recolzen, sí que s'ha accedit a testimonis que parlen de persones que intenten ensenyar uns mínims coneixements de forro a xiquets durant l'estiu (Fernández i Brasa, comunicació personal, 2019), de joves que s'interessen per les tradicions i les llengües del país (Beirão, comunicació personal, 2018), i d'un pla per oficialitzar els criolls que es va entregar al Ministeri corresponent, però que mai es va posar en pràctica (Hagemeijer, comunicació personal, 2019). En l'aspecte musical, cal assenyalar l'aportació de Luís Viegas i el seu cançoner Butá kloson ba lônji⿱⺈, que recull lletres en forro i la seua traducció al portuguès de dos grups musicals de gran tradició: Conjunto Leonino i Os Untués 9 . Al panorama actual, com indica Bouchard (2017), alguns músics opten per l'ús del forro, bé íntegrament o bé

\footnotetext{
8 https://www.telanon.info/cultura/2019/07/13/29658/buta-kloson-ba-lonji-de-luis-viegasapresentado-em-sao-tome/ 9 https://www.telanon.info/suplemento/opiniao/2019/07/17/29700/contra-o-nevoeiro-das-perdasidentitarias-de-sao-tome-e-principe/
} 
combinant-lo amb el portuguès. Els casos més coneguts són el duet Calema $^{10}$ i el grup África Negra ${ }^{11}$, ambdós coneguts tant a São Tomé i Príncipe com a alguns països europeus com Portugal ${ }^{12}$, Alemanya $^{13}$, i França ${ }^{14}$.

\subsubsection{Els criolls a Príncipe en l'actualitat}

Després del tràfic d'esclaus i contractats que van passar per l'illa de Príncipe, aquesta és, igual que São Tomé, un escenari multilingüe. El portuguès també es manté com a llengua dominant (Bouchard, 2017), encara que no s'ha realitzat cap estudi sobre el portuguès a Príncipe fins ara (Hagemeijer et al., 2018). A més del portuguès, a Príncipe podem trobar la presència del crioll capverdià i el lung'ie, autòcton de l'illa.

\subsubsection{Capverdià}

Com s'exposa a l'apartat 5.1, durant la segona colonització del país al segle $\mathrm{XX}$, quan es va implantar el cultiu del cafè i cacau, la malaltia de la son va minvar gran part de la mà d'obra de Príncipe; aleshores van traslladar grups de parlants de capverdià perquè els substituïren a les plantacions (Agostinho i Bandeira, 2017). També s'ha explicat que el capverdià es va poder 
assolir amb facilitat a São Tomé i açò no va ser diferent a Príncipe. Per tant, el capverdià és la segona llengua més parlada (Bouchard, 2017). De fet, segons Agostinho i Bandeira (2017) actualment existeixen més parlants natius de capverdià que de lung'ie a l'illa de Príncipe, on fins i tot hi ha parlants monolingües.

\subsubsection{Lung'ie}

El lung'ie, literalment llengua de l'illa (Hagemeijer, 2016), és una llengua parlada majoritàriament pels més ancians (Agostinho, 2015; Ribeiro de Souza, 2015). Agostinho (2015) calcula que hi deuen haver uns 200 parlants, cap d'ells monolingüe. L'actitud dels parlants d'aquesta llengua té certes similituds amb els parlants de forro: no se sol transmetre de pares a fills, ja que els pares temen que els impedisca aprendre correctament portuguès. A més, encara recorden que antigament es castigava els xiquets que no contestaven en portuguès (Agostinho, 2015).

La malaltia de la son que va patir Príncipe al segle XX va matar gran part dels parlants de lung'ie i aquest fet ha afectat inevitablement el desenvolupament d'aquesta llengua (Agostinho, 2015; Agostinho i Bandeira, 2017), que es troba en greu risc de desaparició (Bouchard, 2017). Príncipe va passar a ser una regió autònoma l'any 1994 i, des d'aquell moment, s'observa una forta associació entre ser de Príncipe i saber lung'ie (Agostinho, 2015). Des del 2009 el Govern de Príncipe ha encoratjat l'ensenyament de lung'ie a les escoles, tot i que el professorat no ha rebut cap tipus de formació i tampoc compten amb materials didàctics ni metodologia específica (Agostinho, 2015; Agostinho i Bandeira, 2017; Castaño, 2012). Com assenyala Dolz (2019) al seu sisé principi de la sociodidàctica de llengües, les habilitats del 
professorat són fonamentals per a assegurar l'aprenentatge escolar $i$, en aquest sentit, caldria donar suport formatiu als docent per tal que l'ensenyament de lung'ie siga efectiu.

Agostinho (2015) explica que els professors de lung'ie són ancians que coneixen la llengua. Es reuneixen cada 15 dies per a programar les classes, però cadascun decideix individualment com i amb quin material les desenvoluparà. Només ensenyen llistats de paraules, no inclouen explicacions sobre estructures lingüístiques o de conversa. No obstant això, l'any 2016 es va publicar un llibre fet per autors locals (Nicolau i Maria Lavres) per aprendre lung'ie (Bouchard, 2017). Aquest fet correspon amb el corpus planning, l'activitat que cita McCarty (2018) com a element d'una planificació lingüística (v. 1.4).

Agostinho (2015) també observa un major interès dels joves per aprendre lung'ie des dels anys 2013-2014. Explica que s'organitzen trobades setmanals per conversar en lung'ie i aquestes solen ser retransmeses per la Rádio Regional do Príncipe. Els registres escrits en lung'ie, igual que els d'angolar, consten d'un conjunt de contes, relats del dia a dia, proverbis i endevinalles (Cardoso et al., 2015).

\subsubsection{Les llengües criolles als mitjans de comunicació}

Les polítiques lingüístiques d'un estat es manifesten al seu sistema educatiu i als mitjans de comunicació (Appel i Verhoeven, 1995) i, en aquest sentit, São Tomé i Príncipe no és una excepció. Generalment, els periòdics del país publiquen les notícies en portuguès, $i$ és als mitjans audiovisuals on es pot trobar una major presència de les llengües criolles, sobretot quan s'emeten videoclips 0 cançons (Antunes, comunicació personal, 2016). 
Al país hi ha tres canals de televisió, dels quals només un és nacional (TVS). Els altres dos, RTP Internacional i RTP África, pertanyen a Portugal. L'RTP Internacional és un servei ideat per a l'afirmació, la valorització i la defensa de la imatge de Portugal i de l'economia, la cultura i la ciència portuguesa arreu del món, a més de ser el contacte amb teleespectadors de llengua portuguesa residents a l'estranger. L'RTP África, en canvi, està dirigit especialment a països africans de llengua portuguesa (RTP, comunicació personal, 2019).

Tots els canals emeten en portuguès excepte alguna programació concreta en forro a la televisió i a la ràdio, on se senten cançons en portuguès, forro, capverdià i, de vegades, també en lung'ie (Hagemeijer et al., 2018; Bouchard, 2017). A la Rádio Regional do Príncipe transmeten programes en lung'ie dos dies a la setmana. Aquests programes consisteixen en converses informals sobre llengua, música, política i la vida a Príncipe en general. Els oients poden telefonar al programa i preguntar dubtes lingüístics (Agostinho, 2015; Agostinho i Bandeira, 2015).

Sembla que la majoria de contingut audiovisual extern que emet TVS procedeix de Brasil, ja siga programació nacional brasilera o estrangera i doblada en aquesta varietat del portuguès. La programació subtitulada és escassa i es limita als documentals i algunes pel-lícules. Quan un contingut o intervenció és en algun crioll, no se subtitula (Malé, comunicació personal, 2019).

Pel que fa a l'RTP, és cert que Portugal és un país amb tendència a subtitular (Bartoll, 2015; Talaván, 2013), encara que a l'informe d'avaluació del compliment estratègic de l'any 2015 (Conselho Geral Independente, 2015) s'assenyalen alguns 
punts a millorar quant a la subtitulació per a persones amb necessitats especials (p. 18) i a la promoció de la subtitulació a l'RTP Internacional (p. 86).

A continuació es mostra l'adaptació d'una taula facilitada per l'RTP en una comunicació personal (2019), on es pot apreciar el percentatge de subtitulació i doblatge emés entre el 2015 i el 2018 pels dos canals de Rádio Televisão Portuguesa que es poden veure a São Tomé i Príncipe:

Taula 5. Percentatge de subtitulació i doblatge emés a RTP Internacional i RTP África (2015-2018). (Taula adaptada de I'RTP, comunicació personal, 2019).

\begin{tabular}{|c|c|c|c|}
\hline ANY & SERVEI DE PROGRAMES & $\begin{array}{c}\text { RTP } \\
\text { INTERNACIONAL }\end{array}$ & RTP ÁFRICA \\
\hline \multirow[t]{2}{*}{2015} & $\begin{array}{l}\text { Programació en llengua } \\
\text { estrangera subtitulada en } \\
\text { portuguès }\end{array}$ & $0,06 \%$ & $0,01 \%$ \\
\hline & Doblatge en llengua portuguesa & $0 \%$ & $0 \%$ \\
\hline \multirow[t]{3}{*}{2016} & $\begin{array}{l}\text { Programació en llengua } \\
\text { estrangera subtitulada en } \\
\text { portuguès }\end{array}$ & $0,56 \%$ & $0,65 \%$ \\
\hline & Doblatge en llengua portuguesa & $0 \%$ & $0 \%$ \\
\hline & $\begin{array}{l}\text { Programació en llengua } \\
\text { portuguesa subtitulada en anglès }\end{array}$ & $0,01 \%$ & \\
\hline 2017 & $\begin{array}{l}\text { Programació en llengua } \\
\text { estrangera subtitulada en } \\
\text { portuguès }\end{array}$ & $0,86 \%$ & $1,06 \%$ \\
\hline
\end{tabular}


Doblatge en llengua portuguesa

$0 \%$

$0 \%$

Programació en llengua

portuguesa subtitulada en anglès

$0,58 \%$

2018 Programació en llengua

estrangera subtitulada en

portuguès

$1,04 \%$

$1,49 \%$

Doblatge en llengua portuguesa

$0 \%$

$0 \%$

Programació en llengua

portuguesa subtitulada en anglès

$0,58 \%$

Com es pot apreciar, el percentatge de programació en llengua estrangera i subtitulada al portuguès durant l'any 2018 és d'un 1,04\% al canal RTP Internacional i d'un 1,49\% a I'RTP África. Aquestes dades mostren que la tendència de subtitular augmenta progressivament, la qual cosa fa pensar que, si es manté aquest creixement, la subtitulació podria tindre una major presència a la televisió de São Tomé i Príncipe en un futur no massa llunyà.

\subsection{L’EDUCACIÓ A SÃo TOMÉ I PRíNCIPE}

L'anàlisi del sistema educatiu de São Tomé i Príncipe va lligada a la seua història, ja que l'educació i la formació són elements condicionants del desenvolupament (Cardoso, 2004). Durant l'època colonial i especialment durant la segona colonització, el país es va organitzar entorn de les plantacions, que constituïen un escenari d'organització de la vida social: dins del territori de cada plantació, els treballadors tenien habitació, escoles i hospitals. Amb 
l'arribada de la independència, aquestes empreses es van nacionalitzar, però la inexperiència dels nous gestors va fer que la continuïtat d'aquest sistema és tornara inviable. La incapacitat econòmica de l'esfera pública i les noves lògiques de les empreses privatitzades van deteriorar progressivament el sistema social del país, i també l'educatiu. La posterior inestabilitat política va impedir la construcció de noves polítiques coherents, i tampoc va ajudar la poca cohesió del país i les seues identitats nacionals. Els forros van assumir un estatus superior respecte a la resta d'ètnies i la identitat del poble encara es recolzava en un model històric en què l'intercanvi de favors ja no era entre el patró i el contractat, sinó entre els que tenien una posició privilegiada i els que podien arribar a tindre-la. Tot açò, juntament amb la tensió que hi havia entre els partits polítics, va impedir, a més de la disminució de la pobresa, la implementació de polítiques socials consistents. La taxa d'escolaritat va disminuir progressivament i no es va començar a recuperar fins l'any 2001. Aquesta falta d'interès per assistir a l'escola i l'abandonament escolar es deuen a diversos factors, com ara la difícil accessibilitat als centres, la baixa qualitat de les infraestructures, la poca qualificació del professorat, etc. (Cardoso, 2004).

A partir de 2011, però, s'han fet esforços per intentar revertir o millorar la situació del sistema educatiu de São Tomé i Príncipe com indica el Ministério da Educação, Cultura e Formação (2012) al seu informe diagnòstic. Tot i això, en aquest informe encara s'assenyalen molts aspectes que s'han de millorar.

La docència és una de les professions menys atractives i el $60 \%$ d'educadors no tenen la formació pedagògica necessària. El professorat de São Tomé i Príncipe és el que cobra menys en comparació al sou que reben els docents en altres països africans. Pel que fa al professorat del segon cicle 
d'ensenyament bàsic, l'informe diu (Ministério de Educação, Cultura e Formação, 2012, p. 5):

E enfim, a maioria dos professores do $2^{\circ}$ ciclo do Ensino Básico e do Ensino secundário (os dois ciclos), dispensam horas de aulas bem menor do que deviam. Assim, 71\% dos professores do ensino secundário dispensam menos de 14 horas de aulas semanais e, um pouco mais do que a metade $(52,5 \%)$ dos professores deste ciclo de ensino dispensam 10 horas ou menos de aulas por semana.

Segons el Ministério da Educação, Cultura e Formação (2012), l'any 2009 un informe demogràfic de salut va revelar que la raó per la qual els joves d'1 a 24 anys no anaven a l'escola 0 abandonaven els estudis era per motius econòmics i pel límit d'edat per a accedir als estudis. Basant-se en aquests resultats, es van projectar nous objectius i estratègies del sector de l'educació per a l'any 2022:

1. L'educació preescolar serà obligatòria, gratuïta i universal per a tots els xiquets i xiquetes entre tres i cinc anys. Aquest objectiu s'aconseguirà amb la construcció de 171 classes, mitjançant la formació de 300 educadors i auxiliars, així com augmentant la inversió en educació.

2. L'educació bàsica (entre els sis $\mathrm{i}$ els 12 anys) garantirà la qualitat educativa mitjançant la formació del professorat, l'equipament de les escoles i l'extensió de l'horari lectiu. 
3. Per tal de garantir la plena universalitat de l'ensenyament i la formació, es prestarà una atenció particular al desenvolupament de l'Educació Especial en tots els cicles. Es capacitaran professors i educadors i s'adaptaran les infraestructures.

4. Es garantirà la universalitat i la gratuïtat de l'ensenyament secundari de qualitat fins al 12é curs. Es formarà 789 docents $i$ es produiran manuals $i$ altres materials didàctics.

5. Quant a l'ensenyament tècnic i professional, s'involucrarà el sector privat a tots els nivells, s'adequarà la formació i els llocs de treball, es planificarà estratègicament pel seu caràcter transversal i s'adoptaran polítiques d'inserció laboral.

6. Pel que fa a l'ensenyament i la formació superior, es procurarà garantir una oferta de qualitat ajustada a models reconeguts internacionalment que puga proveir de recursos humans al país, i es crearà una universitat pública de qualitat amb currículums atractius i adaptats a les necessitats reals de São Tomé i Príncipe.

7. Les autoritats aposten per l'erradicació definitiva de l'analfabetisme en joves i adults a través de l'expansió de la xarxa d'accés a l'educació, en particular a les zones amb més carències i la millora de la qualitat i l'eficiència de l'aprenentatge.

Per la importància del seu impacte al sistema educatiu, s'inclouen entre aquestes estratègies la Tecnologia de Informação e Comunicação (TIC), Saúde Sexual e Reprodutiva (SSR), i l'Escola e a Identidade cultural Santomense. La 
TIC suposarà una ferramenta estratègica per aconseguir l'eficiència, l'eficàcia i la innovació del sistema educatiu. S'implementarà el projecte Escola em Rede que garantirà l'electricitat als centres, un equipament equitatiu i sostenible de totes les escoles i la formació de personal docent i no docent. L'SSR s'instal-larà a als col-legis, que oferiran coneixements sobre salut sexual i reproductiva i higiene. L'Escola e a Identidade cultural Santomense s'entén com una forma en què l'escola participa en la preservació de la identitat cultural del país i promourà l'ensenyament i la investigació orientats al coneixement i la valorització del patrimoni històric i cultural de São Tomé i Príncipe (Ministério da Educaçao, Cultura e Formação, 2012).

Després de l'establiment d'aquestes propostes, un informe del Ministério de Educação, Cultura, Ciência e Comunicação (MECCC, 2016), indica que, en general, la situació de l'educació sí que ha millorat els últims anys. Per exemple, ha augmentat el nombre d'escoles públiques i privades. La taula següent mostra la quantitat de centres educatius per regions del país. Com es pot apreciar, la regió amb més infraestructures és Água Grande (on es troba la capital del país, São Tomé) en detriment del districte de Caué, una de les zones més rurals:

Taula 6. Centres Educatius a São Tomé i Príncipe. (Taula adaptada del MECCC, 2016).

\begin{tabular}{lrrrr}
\hline DISTRICTES & $\begin{array}{c}\text { ED. } \\
\text { PREESCOLAR }\end{array}$ & ED. BÀSICA & ED. SECUNDÀRIA & TOTAL \\
\hline Água Grande & 25 & 21 & 4 & 50 \\
Mé-Zochi & 19 & 20 & 5 & 43
\end{tabular}


R.A. Príncipe

Cantagalo

Lembá

Lobata

Caué
15

13

13

13

7
9

10

11

11

10
4

Pel que fa al personal docent, la majoria es troba en procés de formació i l'informe registra poc progrés. Només el $19,7 \%$ del professorat de preescolar compta amb formació pedagògica i un $23,5 \%$ es troba en procés de formació. En l'ensenyament bàsic, només el $29,2 \%$ del personal té la formació adequada. En l'ensenyament secundari general i tècnic, la taxa bruta d'escolarització se situa en un $93,5 \%$, dels quals un $47,9 \%$ d'estudiants accedeixen a l'últim curs (MECCC, 2016). Les últimes dades de l'Instituto Nacional de Estatística (2018) indiquen una taxa d'alfabetització del 90,1\% i el Minstério de Educação, Cultura e Formação (2012) assegura que l'ensenyament bàsic universal és una realitat des de l'any 2011.

Tindre una visió general de la situació de l'educació a São Tomé i Príncipe és important per a contextualitzar la proposta d'aquesta tesi que, com s'explica en l'apartat 8.2, és coherent amb els projectes d'Escola em Rede i Escola e a identidade cultural Santomense. A més a més, aquest apartat ofereix informació sobre què es pot esperar a nivell d'alfabetització al país, la qual cosa ajuda a valorar la idoneïtat de la subtitulació en aquest cas així com les zones amb majors infraestructures i les que tenen 
més dificultats a l'hora d'aplicar aquesta proposta i poder planificar-la i portar-la a terme de la manera que es suggereix (v. 8.2).

\subsection{COOPERACIÓ A SÃo TOMÉ I PRíNCIPE}

São Tomé i Príncipe és un país en vies de desenvolupament, amb una societat on més del $50 \%$ dels seus ciutadans no tenen ingressos per satisfer necessitats bàsiques (PNUD, 2002). Al Plan de Actuación Especial 2006-2008 (Cooperación Española, 2006-2008) s'assenyalen com a necessitats del país un ensenyament de qualitat amb professors preparats; una millora del sistema de salut i la manca de personal qualificat; la protecció de col-lectius en risc de vulnerabilitat; habitabilitat bàsica $\mathrm{i}$ l'accés a l'aigua potable, entre d'altres. Cooperación Española (2006-2008) indica com a vulnerabilitats del país la inexistència d'una coordinació i una harmonització de les ajudes; una capacitat institucional reduïda per planificar i gestionar el procés de desenvolupament; el baix nivell educatiu de la població; un augment de malalties, com les d'origen hídric o la sida, i una dependència extrema de l'ajuda exterior.

L'informe de l'any 2002 del PNUD exposa més detalladament algunes d'aquestes necessitats:

- En l'àmbit de l'ensenyament, hi ha carències importants en la qualitat: falta de materials i aules, salaris baixos, restriccions pressupostàries, etc. Totes aquestes deficiències desanimen el professorat millor qualificat que és substituït per professorat amb poca o nul-la preparació. L'alumnat, per tant, no rep una formació de qualitat. A 
aquest cercle viciós se li afegeix la insuficiència dels nivells superiors d'ensenyament.

L'esperança de vida és molt alta en comparació amb la majoria de països subsaharians, però encara hi ha problemes importants per resoldre, com el paludisme, la taxa de mortalitat infantil i la malnutrició (causa del 13\% de morts infantils), així com la dificultat en l'adquisició i la distribució de medicaments.

Pel que fa al sistema de parentesc tradicional, cal assenyalar que São Tomé i Príncipe es caracteritza per la poligàmia masculina, l'alta incidència d'unions esporàdiques i la seua inestabilitat, factors que afecten a la composició dels membres de la família. Les famílies es constitueixen essencialment per cohabitació i estan subjectes als efectes de la poligàmia, que sovint és la principal causa que hi haja cada vegada més cases liderades per dones i famílies monoparentals. En conseqüència, són les dones qui tenen la responsabilitat de l'educació i la subsistència dels fills. A més, s'ha de tindre en compte que aquestes famílies monoparentals són un dels sectors més vulnerables a la pobresa, ja que el número de fills per dona és bastant elevat (5,4 l'any 1991) i les relacions de solidaritat i ajuda que antigament eren freqüents, són ara més fràgils a causa de la pobresa. La preocupació per la manutenció familiar fa que els responsables dels xiquets, bé siguen pares o mares, avis o àvies, etc., es vegen obligats a estar fora tot el dia i, per tant, tenen menys temps per a dedicar a la família. Açò desemboca en fenòmens com els meninos da rua (xiquets del carrer, que deambulen sols pel carrer), el treball infantil o l'exclusió social de les persones ancianes. 
Un altre sector vulnerable a la pobresa, com les famílies monoparentals que assenyala el PNUD (2002), són les persones amb discapacitat. Entre les persones que resideixen amb familiars, un $2 \%$ de la població té problemes de visió, un $1 \%$ pateix problemes d'audició i un 1,37\%, problemes relacionats amb la mobilitat. Les persones amb algun tipus de discapacitat que viuen soles són l'11,7\% (Instituto Nacional de Estatística, 2012). Per comprendre quin tipus de repte suposa el dia a dia per a aquestes persones, cal conéixer la marginació a la qual estan sotmeses, tant per la societat com per les pròpies famílies. Tenen problemes d'accessibilitat, de transport, de salut i d'assistència social, perquè no hi ha mecanismes especialitzats per a atendre persones amb discapacitat. A més, tenen carències educatives, ja que no existeix un model educatiu per a persones amb necessitats especials; presenten dificultats per trobar treball i, quan el troben, està molt mal remunerat (Instituto Nacional de Estatística, 2012).

A São Tomé i Príncipe hi treballen més de 150 associacions amb tendència a col-laborar entre si, segons expliquen Cravo et al. (2010). Els autors van enquestar algunes de les ONG sobre diferents aspectes de la seua funció al país. Entre les respostes, les associacions esmenten la bona acollida que solen tindre els projectes per part de la població, tot i que un $15 \%$ comenta que de vegades troben certa resistència als canvis per part de les comunitats. Segons els autors, açò podria evitar-se o reduir-se si es fera una reflexió integrada sobre l'impacte dels projectes implementats en les poblacions a què es destinen. A la mateixa enquesta, algunes ONG es queixen de la falta de capacitació dels seus membres, i demanen formació per als voluntaris en informàtica, recursos financers, gestió i comptabilitat, llengües verbals (no s'especifiquen quines), llengua de signes, gestió ambiental, etc. 
És cert que, des de la seua independència, São Tomé i Príncipe ha viscut de forma quasi exclusiva de l'ajuda internacional. Segurament, açò ha contribuït que el seu nivell de subdesenvolupament no siga tan greu com el d'altres països (Gonçalves de Género, 2012), tot i que allò ideal seria, com diu Álvarez Vilas (2015), formar i aprendre sense crear dependència.

\subsubsection{Persones ancianes a São Tomé i Príncipe}

D'acord amb el cens de l'Institut Nacional d'Estadística de São Tomé i Príncipe de 2012, la població anciana de més de 65 anys representa el 3,7\% de la població total de São Tomé i Príncipe (6.590 persones). Tot i que no hi ha massa bibliografia al respecte, per la importància que aquest sector de la població té per al present treball, cal incidir en la situació que viuen els ancians d'aquest país.

L'informe del PNUD de 2002 assenyala l'exclusió de les persones ancianes com una de les conseqüències de la pobresa al si familiar. Aquesta situació s'agreuja per l'augment de casos d'intolerància i les acusacions de fetilleria (PNUD, 2002). A São Tomé continuen tenint un gran pes l'ocultisme i la bruixeria, independentment de l'estatus social o la procedència de les persones (Espírito Santo, 2009; Muñoz-Torrent, 2015; Neves, 2009; Valverde, 2000), i moltes de les actituds pròpies de l'edat que tenen els ancians (insomni, tremolors, etc.) es relacionen amb actituds pròpies de fetillers i desemboquen en la marginació i el maltractament dels més majors, que es veuen completament desemparats. Potser aquests prejudicis tenen a veure amb el fet que, en l'àmbit del curanderisme, sempre s'aprèn d'una persona més vella (Valverde, 2000).

A aquesta discriminació hem de sumar el canvi als nuclis familiars que explica el PNUD (2002) i que, afegit a 
la pròpia cultura del país, fa que moltes famílies deixen els avis enrere. Podem trobar alguns testimonis d'abandonament 0 desconnexió de la família al llibre de Neves (2009).

L'exclusió de la vida social, econòmica i política de les ancianes i els ancians és la causa principal del seu elevat índex de pobresa. Solen ser les últimes persones a rebre qualsevol tipus de recurs, com ara aliments, aigua potable, sanejament bàsic i protecció social. Es tracta d'un col-lectiu sense visibilitat que es veu arraconat en residències, institucions o en les seues pròpies cases (Cooperación Bierzo Sur, 2012).

Algunes ONG de São Tomé i Príncipe treballen per millorar les condicions de les persones ancianes, però encara queda molt per fer, com es desprèn de les memòries de projectes de Cooperación Bierzo Sur dels anys 2013 i 2014. Aquesta associació espanyola ha realitzat diferents projectes per avaluar i millorar la vida de les persones ancianes. L'any 2013 va començar a realitzar tallers de cuina tradicional, conta-contes $i$ jocs interactius entre els vells i els xiquets de la comunitat de Santo Amaro, per afavorir la integració dels majors i que pogueren ensenyar receptes, històries, danses, etc. que estan perdent-se, així com activitats de conscienciació sobre l'envelliment i la importància de la família en el desenvolupament individual. Encara que aquestes activitats, que normalment s'organitzen durant l'estiu, solen tindre una bona acollida a la comunitat, els resultats i el seu impacte no es podran valorar fins d'ací uns anys.

L'altra part del treball d'aquesta organització amb les persones ancianes va consistir en l'estudi i l'avaluació de les condicions d'algunes cases socials i residències de São Tomé i Príncipe (Cooperación Bierzo Sur, 2014), que depenien d'una altra organització no governamental. En aquestes avaluacions es troben 
cases socials o residències que no estan en bones condicions, fins $i$ tot n'hi ha algunes sense electricitat $\mathrm{i}$ en condicions higièniques nefastes. El 77,77\% dels edificis i habitatges visitats no disposa de subministrament d'aigua. Els ancians que han de recollir aigua de fonts públiques depenen de la inestabilitat de la seua oferta, la distància i del seu estat físic (Cooperación Bierzo Sur, 2014). Durant les visites a persones ancianes de diferents comunitats recullen informació de la realitat a què s'enfronten. Per exemple:

Al finalizar las valoraciones programadas de la tarde nos acercamos al hospital donde se encuentra ingresado un anciano, [...]. Cuando llegamos lo encontramos amarrado a la cama, con la ropa empapada de orina y sin sábanas. Se encuentra desorientado, con el suero acabado y nos comenta el compañero de al lado que lleva todo el día sin comer ni beber nada [...]. A la llegada nos lo encontramos en las mismas condiciones de la tarde anterior, no le han cambiado la ropa mojada de nuevo ni le han dado nada de comer. Realizamos aseo y toma el desayuno. Se habla con la enfermera responsable. En el transcurso de la semana el anciano va empeorando y finalmente fallece. ( $p$. 39)

Se visita a un anciano que vive solo, llegamos a la casa y lo encontramos metido en la habitación con la puerta cerrada, llorando, taquicárdico y taquipneico, con crisis de ansiedad, acostado en una cama sucia, mojada de orina y sin ningún tipo de higiene. Entre llantos nos comenta que lleva dos días sin 
beber agua ni comer nada, [...], refiere que en días anteriores entraron a robarle los vecinos, se llevaron una televisión pequeña que tenia [sic], está asustado y pide AYUDA ${ }^{15}$, "que le ayuden por favor"[...]. (p. 40)

Se realiza la visita de una anciana que vive con una de sus hijas, la encontramos [...] en muy malas condiciones higiénicas, con herida de larga duración (meses) en el miembro inferior izquierdo que presenta mal aspecto y con signos de infección; lleva varios días sin curar [...]. Se realiza la cura y se intenta hacer partícipe e implicar a su hija la cual rechaza nuestra propuesta, proponemos volver al día siguiente para enseñarle a realizar la cura [...]. Al día siguiente [...] encontramos a la anciana sola y en las mismas condiciones que el día anterior [...]. (p. 40-41)

Aquests tres casos serveixen per mostrar la cruesa del dia a dia de les persones ancianes a São Tomé i Príncipe: falta de recursos, d'atenció mèdica i abandonament familiar. A més, a l'informe s'explica que només 12 voluntaris van assistir a la formació de cura d'ancians, entre els quals no es trobava cap treballador ni responsable directe d'aquestes persones (Cooperación Bierzo Sur, 2014, p. 64). 
São Tomé i Príncipe és un país amb un passat dur, que arrastra desigualtats de tot tipus des de l'inici de la seua creació com a Estat fins a l'actualitat. En aquest capítol es poden veure alguns intents recents de millorar certes situacions al país, com les innovacions al sistema educatiu, o les iniciatives a Príncipe per conservar el lung'ie, entre d'altres. En relació amb aquesta tesi, els avanços acadèmics en pro de les llengües criolles del país, així com les apreciacions d'un interès creixent per una part de la població envers el forro, són dades positives que, juntament amb l'augment de la tendència a subtitular de I'RTP Internacional i I'RTP África, així com l'interès de transmetre la cultura pròpia al sistema educatiu, encoratgen el paper de la subtitulació que es presenta en aquesta tesi. Pel que fa a les persones ancianes, com es desprén dels informes de Cooperación Bierzo Sur (2013), una de les majors dificultats per a lluitar contra la seua estigmatització és la falta de participació, d'implicació i de sensibilització de la població. En aquest sentit, la proposta que presenta aquesta tesi podria ser una ferramenta innovadora que estimulara un canvi d'actitud, empatia i compromís de diferents actors per a treballar en favor d'un grup tan vulnerable a través de la revitalització de la seua llengua. 


\section{METODOLOGIA}

Aquesta tesi té un caràcter multidisciplinar que es nodreix de diverses disciplines, la TAV (v. 2), l'etnografia (v. 3), o la cooperació (v. 4). Mentre que la cooperació ha sigut el punt de partida per a l'elaboració d'aquest treball, i la TAV l'instrument principal per a desenvolupar-la, l'etnografia ha suposat la base de la planificació metodològica de tot el treball, com s'explica en l'apartat 6.1 .

En aquest capítol, a més d'aprofundir en la metodologia etnogràfica que s'ha aplicat, s'expliquen altres aspectes de la investigació com els participants (v. 6.2), els instruments utilitzats per a desenvolupar el treball (v. 6.3), el mètode d'anàlisi de les dades finals (v. 6.4), la subtitulació adaptada (v. 6.5) i una temporització (v. 6.6).

\subsection{LA METODOLOGIA ETNOGRÀFICA APLICADA EN AQUESTA TESI}

Des del primer plantejament d'aquesta tesi es va sobreposar el caràcter etnogràfic que prendria, ja que l'objectiu secundari 1 (esbrinar la percepció cultural i lingüística d'un grup d'ancians parlants de forro) i l'objectiu secundari 2 (analitzar les reflexions i opinions de persones no ancianes residents a São Tomé sobre els comentaris dels ancians respecte a la situació que viuen, l'ús de la llengua $\mathrm{i}$ els trets culturals del país) comportaven inevitablement una o més estades al país. En conseqüència, es va plantejar el treball de camp en dos exercicis diferents: les 
entrevistes, imprescindibles per assolir els objectius que s'havien plantejat inicialment, i les notes de camp que completarien les entrevistes i recollirien informació addicional a la qual es poguera accedir.

En setembre i octubre de 2016 es va realitzar una primera estada al país que va servir per establir contactes amb persones i entitats amb qui es treballaria més endavant i per recollir les primeres opinions sobre la situació de les persones ancianes i del forro. Aquesta presa de contacte va ser la base per decidir quin seria l'enfocament de la investigació, els objectius, un primer índex i la bibliografia necessària, així com la zona del país més convenient per treballar.

La segona estada es va realitzar en març i abril de 2018. En aquesta ocasió es va desenvolupar el treball de camp: es van trobar les persones que participarien a la investigació, amb algunes de les quals ja s'havia contactat durant el primer viatge i coneixien la idea general de la investigació, se'ls va explicar en què consistiria i es va enregistrar el seu consentiment informat, que es troba emmagatzemat en un arxiu personal per tal de preservar l'anonimat de les persones participants. Es van realitzar les entrevistes semi-estructurades que es van enregistrar en àudio o vídeo, segons la voluntat dels participants. Algunes de les contribucions es completen amb notes de camp, ja que alguns entrevistats reflexionaven sobre certs aspectes una vegada havia finalitzat l'entrevista i alguns dels temes que s'havien tractat tornaven a sorgir en altres converses. També hi va haver una fase d'observació participant durant el dia a dia d'aquesta estada, en la qual s'esdevenien converses sobre la qüestió dels ancians o de la llengua que queden recollides a les notes de camp, o servien per a proposar noves preguntes a les entrevistes semi-estructurades. Per últim, després d'una anàlisi del material obtingut, es va realitzar un 
informe dels resultats i les conclusions d'aquests resultats, que fonamenta els capítols 7 i 8 . Com es pot comprovar (v. 3.2.1), les activitats realitzades tant a la primera estada com a la segona, coincideixen amb moltes de les propostes de San Vicente (2010) per a un pla d'acció etnogràfic (reflexió, documentació i bibliografia prèvies; treball de camp; entrevistes; gravació; observació participant; informe i conclusions).

Per tindre diferents punts de vista sobre l'objectiu principal d'aquesta tesi, valorar si la subtitulació de vídeos podria utilitzar-se com a eina de cooperació activa per a la integració de persones ancianes o per a programes de revitalització lingüística, es va recórrer a la triangulació de dades (v. 3.2.3). Es van triar tres grups d'experts que podien aportar visions complementàries sobre l'objectiu d'estudi: experts en $\mathrm{Cl}$, experts en TAV i experts en cooperació lingüística. Amb els dos primers es van realitzar dos grups de discussió i amb els experts de cooperació lingüística es van fer entrevistes per motius de disponibilitat d'horaris i localització geogràfica. Al final de cada grup de discussió i cada entrevista, es va demanar als experts que valoraren una sèrie d'ítems com a conclusió del debat, per tal de recollir de manera més clara i esquemàtica quina era la seua opinió sobre certs aspectes concrets (v. 6.2.2) i facilitar l'anàlisi posterior. Aquests ítems resumeixen els temes que s'havien abordat als grups de discussió i les entrevistes i els experts havien de valorar de l'1 al 10 si hi estaven d'acord. Aquesta valoració permet extraure les conclusions finals personals de cadascun dels participants experts després d'haver escoltat les opinions de la resta i la informació que se'ls anava proporcionant per a establir els debats. Cal recordar, que aquesta valoració és anònima i, per tant, no s'extrauen conclusions individuals sinó genèriques de cada grup de discussió excepte amb els experts en cooperació lingüística, amb qui no es va poder realitzar grup de discussió i es va optar per dues entrevistes individuals. En 
conseqüència, la valoració d'ítems de cadascun d'ells és inevitablement identificable. Tot i això, els seus noms i altres dades personals sí que es mantenen en l'anonimat mitjançant pseudònims com els de la resta de participants.

Aquesta tesi és, per tant, una tesi etnogràfica pels aspectes propis del tipus d'investigació que en fa ús (el treball i les notes de camp, les entrevistes, l'observació participant i els grups de discussió). També s'hi troben característiques de les investigacions etnogràfiques com les que defensa Rockwell (2009) (v. 3.1) al desenvolupament i els resultats d'aquest projecte (v. 7): els resultats s'exposen de manera descriptiva, es documenta allò que no està documentat de la realitat social, s'ha realitzat una estada prolongada al país on es basa l'estudi, s'estableix una col-laboració amb els participants locals $i$, per últim, ha sigut un treball flexible $i$ tolerant als canvis espontanis que pogueren succeir, especialment en la fase d'entrevistes a causa de les circumstàncies dels participants (v. 6.2.1, 6.2.2).

El mètode etnogràfic s'ha considerat el més adient per a aquesta investigació, ja que, com assenyala Nolla (1997), permet analitzar el comportament, les creences i els valors d'un grup d'individus, en aquest cas, les persones ancianes, els entrevistats i les entrevistades de São Tomé i Príncipe i els experts consultats. Gràcies a la utilització d'aquesta metodologia, ha sigut possible entrevistar persones i establir converses de forma més personal i conéixer la seua noció de la realitat de primera mà i dins del seu entorn; contrastar i posar en context l'opinió dels experts que ofereixen la seua visió personal externa i arribar a unes conclusions emmarcades dins la situació actual de São Tomé i Príncipe. 


\subsection{PARTICIPANTS}

Els participants d'aquesta investigació es poden dividir en: participants de São Tomé (persones ancianes i persones no ancianes) i participants experts (experts en $\mathrm{Cl}$, experts en TAV i experts en cooperació lingüística). La implicació de tots ells va consistir en entrevistes i grups de discussió, com s'explica als apartats 6.3.1, 6.3.2 i 6.3.3. En aquesta tesi no es fa referència als noms autèntics d'aquestes persones ni a cap dada personal que puga posar en risc el compromís de confidencialitat. Els consentiments informats de tots $i$ totes, alguns dels quals es van enregistrar en vídeo a l'inici de les entrevistes, es troben emmagatzemats en un arxiu personal per tal d'assegurar-los l'anonimat.

Una vegada aclarits aquests punts, el present apartat se centra en introduir el perfil de totes les persones participants per a poder comprendre més àmpliament les seues respostes.

En primer lloc, es van gravar unes entrevistes realitzades a tres ancians de São Tomé sobre la percepció que tenen de la situació social que hi viuen, però també de la situació del forro i d'algunes tradicions del país. Amb aquestes entrevistes es va fer un vídeo de 12 minuts en forro que exposa els pensaments i els sentiments d'aquestes persones sobre el país que han conegut en la seua joventut i com el veuen ara en termes socials i culturals.

En segon lloc, es va subtitular en portuguès aquest vídeo prescindint de les convencions habituals (v. 2.2) per assegurar la correcta lectura i assimilació dels subtítols. Aquestes adaptacions s'expliquen més extensament en l'apartat 6.5. 
Posteriorment, es van entrevistar 16 persones de diferents edats, sexe i professió residents a São Tomé. En una primera fase, responen preguntes sobre la percepció que tenen de la cultura, la llengua i els ancians del país. Després se'ls mostra el vídeo anterior i, en una segona fase, s'aprofundeix més en aquests temes i es convida a la reflexió d'acord amb el que expliquen els ancians del vídeo.

Per tal de validar les dades recollides al terreny, es van realitzar tres consultes a experts que van contribuir als resultats finals d'aquesta tesi des del seu àmbit de coneixement: dues entrevistes a dos experts en cooperació lingüística, un grup de discussió amb sis experts en $\mathrm{Cl}$ i un segon grup de discussió amb quatre experts en TAV.

\subsubsection{Participants de São Tomé i Príncipe}

Al treball de camp van participar un total de 19 entrevistats, d'entre els quals tres van ser els ancians amb qui es va crear el vídeo que serviria per a entrevistar les altres 16 persones.

Les respostes $\mathrm{i}$ els comentaris que van proporcionar es van recollir en àudio o vídeo i també mitjançant notes de camp. A aquells que no van voler que se'ls gravara o que es donaren dades concretes de la seua vida, com l'edat o la professió, se'ls va oferir triar conjuntament unes dades fictícies aproximades a la realitat. Per exemple, en lloc de referir el tipus de negoci que dirigeix algun d'ells, es dona simplement la professió genèrica «empresari», o en lloc de referir el lloc concret de treball, es facilita la funció general que desenvolupa, per exemple «administratiu». Per tal de conservar el seu anonimat, tots els noms que apareixen en aquesta tesi són pseudònims. Tots ells van acceptar participar i se'ls va explicar en què consistia l'estudi i que, a no ser que especificaren el contrari, les seues declaracions es 
podrien compartir amb fins acadèmics. En aquesta tesi no es faciliten els vídeos de les seues intervencions ja que van expressar el consentiment informat de manera verbal i, per tant, es veure compromès el seu anonimat.

Es van seleccionar persones que residien a la ciutat de São Tomé per ser la localitat més poblada, on és fàcil trobar gent de procedències diferents (tant de distints districtes com de diferents països) i per ser on es troben la major quantitat de persones d'origen forro ${ }^{16}$, a més de punt de convivència i barreja amb altres ètnies del país (Bouchard, 2017), la qual cosa podia oferir resultats interessants.

\subsubsection{Persones ancianes}

Les tres persones ancianes que es van entrevistar es van seleccionar d'un menjador social per a persones majors de la ciutat, del qual s'evita donar el nom per assegurar l'anonimat dels participants. Aquest centre ofereix desdejuni i dinar sis dies a la setmana per a les persones ancianes que hi vulguen anar, però no actua com a residència ni es realitzen més activitats per als ancians durant el dia. Entre les persones que parlaven forro, tres es van oferir a participar, als que anomenarem a partir d'ara Graça, Juliana i Fernando.

La primera persona que es va entrevistar va ser Graça, de 73 anys. Estava contenta de participar i va intentar 
convèncer una amiga que es trobava present perquè participara també, sense èxit. Va explicar que una filla seua viu a Portugal, encara que no sap ben bé què fa.

Juliana, de 78 anys, ja havia sentit parlar de l'entrevista de Graça i va acceptar de bon grat participar-hi. Tot i que la comunicació amb ella era molt difícil pels seus problemes d'oïda i de parla, va resultar una de les entrevistes més extenses, ja que oferia respostes molt completes per iniciativa pròpia. Una altra dificultat era que tendia a parlar en portuguès (encara que no el parlava molt bé) i li resultava molt divertit l'exercici de dirigir-se a l'entrevistadora estrangera en forro.

Fernando tenia 87 anys. Se li va explicar detalladament en què consistia l'estudi i es va mostrar ben disposat per a participar, encara que li feia vergonya. Tot i que tendia a passar-se al portuguès per no estar habituat a parlar una altra llengua amb estrangers, també va proporcionar molta informació quant a la percepció de la vida de les persones ancianes.

\subsubsection{Persones no ancianes}

Per a l'elecció d'entrevistats a São Tomé es va optar per un mostreig, en part de cadena de referència, en part de quota (Mendieta, 2015). Com que trobar el número d'entrevistats suficient podia ser difícil per diferents motius, especialment perquè l'entrevista tracta un tema tabú del qual no se sol parlar i no es podia preveure quina seria la reacció de persones desconegudes, per tal d'evitar possibles situacions tenses o incòmodes, es va decidir començar per amistats personals que van sorgir durant la primera estada (l'any 2016) i, amb la seua ajuda, durant la segona estada (l'any 2018), es va poder accedir a altres persones (mostreig de 
cadena de referència). Amb el temps, i per motius aliens a aquesta investigació, es va coincidir amb més persones que també van voler participar i que complien amb una sèrie de consideracions que es buscaven, com ara, un cert equilibri entre homes i dones, varietat a les professions i, sobretot, varietat en l'edat per a poder analitzar si aquests factors determinaven les respostes dels entrevistats (mostreig de quota). D'aquesta manera, hi ha quatre entrevistats menors de 20 anys, cinc entre 20 i 30 anys, dos entre 30 i 40 i cinc entre 40 i 50 anys.

Cal assenyalar que tres de les persones entrevistades eren estrangers que vivien a São Tomé més de 8 anys. Es va decidir buscar aquest perfil per considerar interessant quina era l'opinió externa de la situació lingüística i cultural del país, especialment pel que fa a la situació de les persones ancianes i fins a quin punt en serien conscients els expatriats a São Tomé. Al contrari del que es podia pensar en un principi, va resultar difícil trobar persones amb aquestes característiques que volgueren participar. Dos van rebutjar obertament la proposta, fins i tot assegurant-los l'anonimat. Una tercera va acceptar finalment, per recomanació d'una amiga en comú a qui ja s'havia entrevistat. Tot i això, li va costar decidir-se i es van haver d'acordar moltes condicions. Per aquesta dificultat, es van limitar les entrevistes a estrangers a aquells amb qui hi havia una relació prèvia, a excepció de la persona citada anteriorment. Per tant, els altres dos entrevistats són amistats personals. A continuació, es descriuen les característiques de tots els participants:

- Abigail i Flávia tenen 18 anys i són pediatres tradicionals. Tenen un fill cadascuna i les dos els crien en portuguès. 
- $\quad$ Elmer està a punt d'acabar els estudis bàsics i té 19 anys. Espera anar a la universitat en setembre de 2018. No té fills. La seua llengua materna és el portuguès i aquesta és també la llengua que més utilitza.

- $\quad$ Miguel es defineix com atleta i té 20 anys. La seua llengua materna és el forro, encara que la que més utilitza és el portuguès. En el seu dia a dia escolta per igual portuguès, forro, angolar i capverdià. No té fills.

- $\quad$ António té 30 anys i és cuiner al centre on es va entrevistar a Fernando, Graça i Juliana. La seua llengua materna és el forro, però la que més utilitza és el portuguès. Té fills i els parla en portuguès.

- $\quad$ Amanda és perruquera i té 26 anys. La seua llengua materna és el forro, la que més utilitza és el portuguès. Té un fill, a qui parla en portuguès.

- Mafalda té 29 anys i és treballadora domèstica. La seua llengua materna és el forro i la que més utilitza, el portuguès. Té un fill a qui parla en portuguès.

Wilson estudia i, al mateix temps, treballa de paleta. Té 26 anys. La seua llengua materna és el portuguès. Té una filla, a qui també parla en portuguès «perquè encara és un bebè». Diu que sol adaptar-se a la llengua que parle el seu interlocutor: si parla forro, ell parla forro; si parla portuguès, li parla portuguès.

- $\quad$ Alda és treballadora domèstica i té 36 anys i 3 fills. Diu que la seua llengua materna és el forro, però més avant conta que no comprèn algunes coses i que sap entendre'l més que parlar-lo, ja que només ho ha començat a fer 
recentment per a dirigir-se a persones majors. La seua mare de vegades li parlava forro i de vegades portuguès. Als seus fills els parla portuguès i alguna expressió en forro. Pensa que el portuguès és la llengua més «correcta» per parlar amb xiquets. En el seu dia a dia, escolta tots els criolls i també el portuguès.

- $\quad$ Matilde és administrativa de l'hospital, de 37 anys. Té una filla de 5 anys i diu que li parla en portuguès i forro, i que ella utilitza per igual aquestes dues llengües, tot i que el que més sent és portuguès, francès i anglès. Observa que cada vegada hi ha més interès per l'anglès.

- $\quad$ Amélia és directora d'una reconeguda ONG a São Tomé i Príncipe. Té 46 anys i 2 fills a qui parla en portuguès, que és la seua llengua materna. Aquesta també és la llengua que utilitza més i la que més sent a la seua vida diària junt amb el forro.

- Diogo es defineix com a horticultor i té 41 anys. La seua llengua materna és el portuguès, i també és la llengua que més utilitza i la que parla als seus 4 fills. A més, també sent forro, anglès i francès.

- $\quad$ Élio és fill de capverdians. Té 45 anys i és paleta i pedrer. La seua llengua materna és el crioll capverdià, però utilitza més el portuguès. Normalment sent també forro i francès. No té fills.

- $\quad$ Alice té al voltant de 50 anys i viu a São Tomé des de fa més de 25. Va nàixer a Portugal i es va criar a Suïssa. Actualment és empresària. Parla portuguès (llengua materna), francès, espanyol i un poc d'anglès. 
- $\quad$ Evaristo té 22 anys i va nàixer al Gabó. Fa 8 anys que viu a São Tomé. Treballa de barber, fotògraf i guia turístic. Tot i sentir-se més còmode amb el francès, Evaristo ja sabia portuguès quan va arribar, perquè els seues pares eren de São Tomé.

- Deolinda és capverdiana, té uns 50 anys i en fa més de 30 que viu a São Tomé. És comptable i parla portuguès i crioll capverdià (llengua materna). Recentment dedica el seu temps lliure a intentar ajudar els ancians d'origen capverdià que viuen a les antigues plantacions.

\subsubsection{Participants experts}

Els experts que complementen aquesta investigació amb la seua opinió es van triar per la seua relació amb la $\mathrm{Cl}$, la TAV i la cooperació lingüística, ja que són els pilars fonamentals i relacionats entre sí que justifiquen aquesta tesi. Per recollir les opinions d'aquests experts, es van realitzar dos grups de discussió, un amb sis experts en $\mathrm{Cl}$ i l'altre amb quatre experts en TAV —la recomanació de Castaño et al. (2017) que es menciona en l'apartat 3.2.1, és que els grups de discussió compten amb entre cinc i deu participants, però un dels experts en TAV amb qui es va contactar i que havia acceptat participar, finalment no s'hi va presentar-, i una entrevista amb dos membres de l'organització Garabide (v. 4.2.1.2), que treballa específicament en cooperació lingüística.

Els experts en $\mathrm{Cl}$ van participar en un primer grup de discussió que es va realitzar el 7 d'abril de 2019 a Ponferrada durant les VI Jornadas de Voluntariado Internacional. Aquest grup de discussió el formen un antropòleg amb experiència en cooperació a Amèrica Llatina (César), una infermera i presidenta d'una ONG que treballa a São Tomé i Príncipe (Celia), una 
especialista en artteràpia amb experiència en cooperació a Uganda (Esther), una infermera que coopera en Àfrica (no especifica país) (Begoña), un treballador de la construcció (Mario) i una infermera (Ruth), ambdós amb experiència com a voluntaris a l'illa de São Tomé. Entre aquests participants, dos cooperen o han cooperat amb organitzacions o projectes grans, mentre que la resta cooperen o han cooperat amb organitzacions $\mathrm{i}$ projectes més menuts $\mathrm{i}$ de proximitat. Actualment, només dos d'ells continuen participant activament en projectes de cooperació al terreny.

El segon grup de discussió, realitzat a València el 12 de juny de 2019, el conformen els professionals de la TAV, entre 3 i 20 anys a la professió: una experta en subtitulació amb una llarga experiència en projectes d'accessibilitat (Marina); una experta en doblatge i subtitulació (Mar); una persona amb experiència variada en les modalitats de TAV (subtitulació per a persones sordes, doblatge, subtitulació, localització, audiodescripció i veus superposades) (Clara); i un expert en accessibilitat i sincronització de subtítols (Jordi).

Els dos experts de Garabide, (Josu) i (Patxi), tenen una experiència de 15 anys a l'ONG, donant suport a comunitats de diferents parts del món que volen revitalitzar llengües minoritzades des de l'experiència de la revitalització de l'eusquera. Aquestes entrevistes es van realitzar telemàticament en juliol de 2019.

\subsection{INSTRUMENTS}

Els instruments per portar a terme aquesta investigació són propis de la metodologia etnogràfica, que permet 
aprofundir en les opinions dels participants i analitzar el context de les seues respostes per extreure les conclusions que ens permeten valorar aquest estudi. Els mètodes que s'han emprat són les notes de camp, les entrevistes i els grups de discussió. A l'annex I es troben les transcripcions de les entrevistes inicials als ancians $i$ a l'annex II el vídeo final que es va subtitular. L'annex III conté les transcripcions de les entrevistes a les persones no ancianes i l'annex IV les transcripcions de les entrevistes i els grups de discussió amb experts. Totes les transcripcions es presenten en l'idioma original excepte les que corresponen a les intervencions de les persones ancianes, que s'han traduït al català per a possibilitar la comprensió del contingut. Els annexos V, VI i VII contenen les frases que s'han utilitzat per a motivar el debat amb els participants experts. A més a més, l'adaptació de la subtitulació ha sigut una ferramenta imprescindible per a poder materialitzar les entrevistes a persones no ancianes de São Tomé amb el suport audiovisual i aconseguir, per tant, assolir els objectius secundaris tres i quatre (v. 8.3.1).

\subsubsection{Entrevistes}

\subsubsection{Entrevistes a persones ancianes}

Aquestes entrevistes es van planificar amb l'objectiu d'aconseguir un testimoni sincer dels ancians sobre la percepció que tenen de la seua realitat social, lingüística i cultural (OS1). En un principi, l'estructura que es va considerar més adient per tractar amb ancians és la que proposa Seidman (2013), que aconsella realitzar les entrevistes en tres fases: una primera per establir la història de vida de l'entrevistat/da en relació amb el tema central de l'entrevista, una segona per esbrinar l'experiència contemporània de l'entrevistat/da sobre el tema que es tracta i, per últim, una tercera fase perquè l'entrevistat/da puga reflexionar de 
manera més profunda sobre el tema principal. A més, també es pretenia seguir la indicació de Seidman (2013) pel que fa al temps recomanat entre cada fase, ja que es considera que els resultats són millors si passen entre tres dies i una setmana entre una fase de l'entrevista i la següent. El guió planificat inicialment, per tant, era el següent:

Taula 7. Guió inicial de les entrevistes als ancians

\section{A FASE}

1. On vas nàixer? Com era la teua família?

2. Amb qui vivies? Vivies amb ancians? Com eren? Quina funció tenien? Què pensaves d'ells? Quines llengües parlaven?

3. Quina llengua parlaves a casa/zona on vivies?

4. (Si no parlava la llengua a casa) Com vas aprendre forro?

5. En quines situacions el parlaves?

6. Anaves a l'escola? Quina era la llengua d'ensenyament? En quina llengua jugaves? Si el mestre parlava amb els teus pares, en quina llengua era?

7. Cantaves en forro, o et contaven algun conte en forro? Ens el pots contar/cantar? Qui el contava/cantava?

8. Podies parlar forro lliurement o estava mal vist? Alguna vegada t'has sentit malament per parlar forro?

9. Al teu poble teníeu festes/cançons/receptes/jocs/danses en forro? Com eren? Encara es fan? Creus que els més joves les coneixen?

10. En quina llengua els parlaves als teus fills? Per què? 


\section{A FASE}

1. Com has arribat a aquest centre?

2. Com és el teu dia a dia? Quines activitats fas?

3. Has fet amics al centre?

4. Quines llengües es parlen al centre? Amb qui parles forro? En quines situacions?

5. Quines festivitats celebreu? Què mengeu en eixos dies? Canteu o toqueu música? Què canteu/quins instruments utilitzeu? Han canviat aquestes festivitats amb les anys?

6. Quin és el menjar/cançó/dansa/instrument que més t'agrada? Per què?

7. Teniu visites al centre? De qui?

8. Vegeu la TV o escolteu la ràdio? En quina llengua és? Quina programació?

9. T’agradaria que hi haguera programació en forro?

10. Com és la teua vida com ancià? Com et sents? Pensaves que seria així?

11. Quan eres jove hi havia centres de dia com aquest? Coneixies algú que hi anara? El visitaves? Com estaven els ancians llavors?

\section{A FASE}

1. T'agradaria que els xiquets aprengueren forro a l'escola?

2. Creus que hi ha aspectes de la teua cultura que es perdran amb la llengua?

3. Creus que és important que es mantinguen? Per què? 
4. Què creus que pots aportar als més joves?

5. Què és el forro per a tu?

La realitat és, però, que encara que sí que es mantenen tres fases d'entrevista diferenciades (passat-presentreflexió), no va ser possible seguir aquesta estructura per complet. En primer lloc, el centre no tenia control sobre la freqüència de visites dels ancians $\mathrm{i}$, per tant, no podien assegurar que durant els dies següents trobaríem els mateixos entrevistats. Considerant l'edat avançada dels participants i les possibilitats de contraure alguna malaltia o que patiren algun tipus de situació personal per la qual decidiren no tornar al centre $o$ es veieren impedits de fer-ho, es va decidir fer les tres fases de l'entrevista en un dia. A canvi, per fomentar la familiaritat i la proximitat entrevistadora-entrevistat, cada dia es dedica a un únic ancià i la seua entrevista completa. A més, com recomanen Robertson i Hale (2011), les entrevistes estan personalitzades i són bastant flexibles. Per exemple, amb Fernando es va estendre més la part on parla del txiloli, ja que és una tradició en la qual ha participat activament durant molts anys, i també en l'entrevista se li pregunta per la situació dels ancians, ja que se'l notava menys cohibit i més dispost que Graça i Juliana per parlar extensament d'eixe assumpte.

Tot i que hauria sigut desitjable disposar d'una habitació en la qual estiguérem únicament l'entrevistadora i la persona entrevistada, les gravacions es van desenvolupar en una sala en la qual es trobaven altres ancians que no parlaven forro i que van seguir el procés de les entrevistes amb curiositat. En cap moment van interrompre i només van intervindre al final. En alguna entrevista, quan l'entrevistat no sabia què respondre, l'animaven o li 
donaven idees per a continuar, però mai van exposar el seu punt de vista i es van mostrar molt respectuosos amb l'experiment.

Els motius per realitzar les entrevistes en aquesta sala eren, en primer lloc, que les altres dues habitacions disponibles estaven massa prop de la cuina i hi havia molt de soroll. Açò hauria dificultat la correcta gravació de les entrevistes i, a més, alguns entrevistats tenien problemes d'oïda i, per tant, hauria resultat molt difícil tindre una conversa fluida. En segon lloc, les habitacions més privades tenien pitjor ventilació, a més de la calor per la seua proximitat a la cuina. Hem de tindre en compte que aquestes entrevistes es van realitzar durant el mes de març de 2018, un dels més calorosos a São Tomé i Príncipe. Com que la intenció era que els ancians es trobaren còmodes amb la seua participació i per assegurar el seu benestar, es va triar l'habitació millor ventilada, tot $\mathrm{i}$ que era una sala comuna on s'havien reunit altres persones per refugiar-se de la calor. Tot i això, abans de començar, se'ls va demanar permís per interrompre el seu temps d'esbarjo. Després de donar el vistiplau, van ajudar a preparar la zona de gravació.

En començar les entrevistes, es va fer evident que resultaria difícil seguir el guió que s'havia preparat: els entrevistats passaven d'un tema a un altre i no entenien algunes preguntes (per exemple: «què és el forro per a tu?»). A més, el sistema habitual de pregunta-resposta generava respostes molt sistemàtiques tipus sí/no, que impedien la reflexió que es buscava. Finalment, es va decidir deixar-los certa llibertat perquè expressaren allò que volgueren i es van utilitzar les preguntes només per guiar la conversa. Així mateix, es van suprimir les preguntes més abstractes, com la citada anteriorment, perquè els resultaven confuses i els treien de l'atmosfera que havíem creat. Cal assenyalar que es va comptar amb l'ajuda d'una treballadora d'aquest centre que actuava d'intèrpret de forro per facilitar la fluïdesa de les entrevistes. 
En general, es va intentar que en cada conversa estigueren presents les tres fases que s'havien planificat: una primera en la qual se'ls pregunta per la seua vida en el passat (amb qui vivien, com eren els ancians abans, quines llengües parlaven, etc.); la segona, sobre aspectes actuals de São Tomé, com cançons i tradicions; en la tercera fase, reflexionen sobre com veuen en l'actualitat la llengua, les tradicions i la vida dels ancians en comparació amb el que ells recorden del passat i el que ja ens havien contat. Com a resultat, es va obtindre un material d'entre $25 \mathrm{i}$ 30 minuts, que parla sobre l'origen d'aquestes persones, com era abans la vida dels ancians i l'ús del forro, d'algunes tradicions i de la seua visió sobre la situació dels ancians i el forro. Aquestes gravacions es va resumir en un vídeo de les tres entrevistes combinades de 12 minuts de duració ( $\mathrm{v}$. annex II), i és el que més endavant es mostra als 16 entrevistats posteriors.

Inicialment, es va plantejar que el vídeo que es mostraria a les persones no ancianes no havia de passar dels 1015 minuts de duració per a no cansar-les o distreure-les en excés de les seues obligacions. Els criteris per a seleccionar el contingut que aniria al vídeo final es basen en la coherència del discurs de cadascun dels ancians amb els objectius de la tesi. Sovint canviaven de tema sense adonar-se'n o perquè no havien entés bé la pregunta i tornaven a parlar de qüestions que ja havien quedat enrere a l'entrevista. Després de seleccionar la informació corresponent al tipus de reflexió que es buscava en les persones no ancianes, es va fer una segona tria per evitar que hi haguera informació repetida i així es va poder acurtar el vídeo fins als 12 minuts (dins la duració que s'havia previst). El contingut final es va organitzar per temes de conversa i segons les intervencions dels ancians, per tal que el vídeo fora més dinàmic i la informació estiguera més clara per a facilitar les possibles referències o comentaris dels entrevistats no ancians. 
Abans de continuar, però, cal aclarir els termes culturals que sorgeixen durant les entrevistes als ancians com a exemples d'esdeveniments tradicionals que consideren que ja no interessen a la joventut, i pels quals es pregunta posteriorment als entrevistats no ancians del país:

- Txiloli. Representació del conflicte entre la cort medieval de Carlemany i la del Marquês de Mântua (de Araujo i Hagemeijer, 2013). Aquesta obra de teatre popular, d'unes sis hores de duració, on la música i la dansa són de gran importància, compta $a m b$ una àmplia bibliografia $i$ existeixen diferents estudis sobre aquesta celebració (v. 3.3).

- Dansu-kongô. Representació amb uns trenta figurants, que s'executa al so de diferents instruments musicals (de Araujo i Hagemeijer, 2013).

- Uswa. Dansa tradicional (de Araujo i Hagemeijer, 2013).

- $\quad$ Bokadu. Ritual familiar que se celebra els Dimecres de Cendra durant el qual la persona més anciana de la família alimenta la resta de membres introduint a la boca de cadascun una cullerada de kalu (o calulu en portuguès), un aliment tradicional (de Araujo i Hagemeijer, 2013).

Ladenha. Segons el testimoni de Fernando i d'alguns dels entrevistats de São Tomé, és la forma antiga de celebrar els soterraments i passar el dol. Durant huit dies, es menja i es beu amb els familiars de la persona que ha mort i passen eixos dies junts. 


\subsubsection{Entrevistes a persones no ancianes}

La intenció principal de les entrevistes a persones no ancianes de São Tomé era esbrinar quina és la seua opinió general sobre la situació dels ancians i del crioll forro segons la seua edat, sexe i professió; també analitzar si aquesta percepció canviava després de veure el vídeo dels tres ancians o si els convidava a algun tipus de reflexió (OS2), i quina opinió els generava el material audiovisual subtitulat (OS3). Aquestes últimes preguntes es basen en l'estudi de Kruger et al. (2007) a Sud-àfrica, que també s'interessava per la percepció de la subtitulació de les persones participants.

Es va plantejar, per tant, un model d'entrevista semi-estructurada, en la qual tots els entrevistats tenien una sèrie de preguntes en comú però que, depenent de les característiques de l'entrevistat/da i de les respostes que donava, podien completar-se amb altres preguntes 0 modificar-se lleugerament. Per exemple, en el cas de les persones estrangeres que vivien a São Tomé, se'ls va preguntar si consideren que coneixen la cultura del país bé. Aquesta pregunta, en canvi, no es va realitzar als natius. Es pot trobar un altre exemple d'aquestes variacions entre entrevistats entre aquells que tenen fills (i aleshores se'ls preguntava quin coneixement tindrien els seus fills dels temes que es tracten) i aquells que no en tenen. En general, però, l'estructura de les entrevistes és la següent: 
Taula 8. Guió general de les entrevistes a

persones no ancianes

ENTREVISTES A PERSONES NATIVES

ABANS DE VEURE EL VÍDEO

1. Quina és la teua llengua materna?

2. Tens fills? En quin idioma els parles?

3. Quina és la llengua que més utilitzes en el teu dia a dia?

4. Amb quines llengües estàs en contacte en el teu dia a dia?

5. Quina creus que és la millor llengua per a l'ensenyament, per a fer gestions, per anar al metge, etc.?

6. Quan es parla forro?

7. Saps què són chocalhos, txiloli, dansu-kongô, uswa, i ladenha?

8. (Si té fills) Els teus fills sabrien què són?

DESPRÉS DE VEURE EL VÍDEO

1. Quina és la teua opinió general del vídeo?

2. Has necessitat llegir els subtítols?

3. T'has sentit còmode/a veient un vídeo amb subtítols?

4. T’agradaria veure televisió subtitulada?

5. Coneixies alguna de les cançons que es canten al vídeo? 
6. T'agradaria que s'estudiara forro a l'escola?

7. T'agradaria que hi haguera més programació en forro als mitjans de comunicació?

8. Penses que la situació de la llengua, la d'alguns trets culturals del país i la situació del forro estan relacionats?

9. Com penses que es podria solucionar?

ENTREVISTES A PERSONES NO NATIVES

ABANS DE VEURE EL VÍDEO

1. Quants anys portes ací?

2. Vas necessitar aprendre alguna llengua per viure ací?

3. Et relaciones més amb persones natives, amb altres estrangers o per igual amb uns i altres?

4. Consideres que coneixes la cultura del país bé, regular o malament?

5. Alguna vegada t'has plantejat aprendre una altra llengua del país?

6 Saps quantes llengües es parlen a São Tomé?

7. Quina has sentit més?

8. Quan es parla forro?

9. Saps què són chochalhos, txioli, dansu-kongô, uswa, i ladenha?

DESPRÉS DE VEURE EL VÍDEO

1. Quina és la teua opinió general del vídeo? 
2. Has necessitat llegir els subtítols?

3. T'ha resultat difícil?

4. Et sents còmode/a sentint forro amb subtítols en portuguès?

5. Veuries televisió subtitulada? Per què?

6. Coneixes alguna de les cançons que es canten al vídeo?

7. T'agradaria que el forro s'estudiara a les escoles o a la universitat?

8. T'agradaria que hi haguera més programació en forro als mitjans de comunicació?

9. Creus que hi ha alguna relació entre l'abandonament d'ancians i la pèrdua de la llengua i tradicions del país?

10. Consideres important evitar-ho, o creus que és millor deixar que el progrés seguisca el seu curs?

11. Com creus que es podria fer?

\subsubsection{Entrevistes a experts en cooperació lingüística}

Els membres de Garabide suposen l'únic referent en cooperació lingüística $a m b$ qui ha sigut possible contactar. Per tant, la intenció principal de l'entrevista que se'ls va realitzar era obtindre el seu punt de vista sobre els efectes de la subtitulació de vídeos en forro de temàtiques culturals i etnològiques relacionats amb ancians de São Tomé i sobre si la subtitulació podria servir per a desenvolupar programes d'integració d'ancians o de revitalització lingüística (OP). Basant-se en aquest plantejament, i 
després d'explicar als participants (Josu i Patxi) la situació sociolingüística de São Tomé i Príncipe, les entrevistes (en castellà) es van estructurar de la manera que mostra la taula 9.

Per tal de convidar-los a la reflexió i estimular la discussió sobre la qüestió que es planteja per tal de conèixer la opinió dels participants experts sobre la idoneïtat d'emprar la subtitulació com a eina de revitalització lingüística i de cooperació, a les tres sessions (amb experts en cooperació lingüística, Cl i TAV) s'han utilitzat la mateixa sèrie de frases extretes de les entrevistes realitzades a São Tomé i Príncipe sobre la percepció dels entrevistats i les entrevistades envers la llengua (llengua i ancians, llengua i educació, llengua i sentiments) ( $v$. annex VI) i la subtitulació ( $v$. annex VII). Totes les frases es presenten en castellà, ja que la majoria dels experts procedeixen de diferents punts de l'Estat Espanyol i no tenen nocions de català, que també es reflecteixen a les taules corresponents (taula 9 al cas dels experts en cooperació lingüística).

Aquestes dues entrevistes i les discussions dels grups finalitzen amb una valoració d'ítems, proposats com a conclusió individual i personal de la sessió, per tal de facilitar l'anàlisi posterior de les opinions personals de cada participant respecte a la discussió.

Taula 9. Entrevista amb experts en cooperació lingüística BLOC 1 APORTACIÓ D’INFORMACIÓ

Explicación de la propuesta de la tesis

Valoración de las frases sobre lengua y subtitulación extraídas de las entrevistas a los participantes de Santo 
Tomé y Príncipe (v. annexos VI i VII).

BLOC 2

RONDA DE PREGUNTES

1. ¿Qué te parece la iniciativa desde tu experiencia?

2. ¿Qué efectos tendría la subtitulación en el caso de Santo Tomé y Príncipe?

3. ¿Conoces otros casos en los que se podría aplicar la subtitulación de forma similar?

4. Para una ONG, ¿sería viable a nivel económico utilizar la subtitulación?

5. ¿Quién realizaría los subtítulos?

6. ¿Cómo se distribuiría el material subtitulado?

7. ¿Qué problemas podrían surgir en el caso de utilizar la subtitulación en cooperación lingüística?

BLOC 3

\section{VALORACIÓ D'ÍTEMS}

La subtitulación es una herramienta útil en proyectos de revitalización lingüística.

La subtitulación es una herramienta útil en proyectos lingüísticos de $\mathrm{Cl}$.

La subtitulación es útil en la sensibilización sobre el criollo forro y las personas ancianas en Santo Tomé y Príncipe.

\subsubsection{Grups de discussió}

Els dos grups de discussió, tot i que són diferents entre sí, tenen algunes característiques comunes: en un principi, els participants no sabien quin era el tema exacte a tractar, 
per evitar possibles influències o idees preconcebudes que pogueren afectar la qualitat dels resultats. Se'ls anava facilitant la informació a mesura que avançava la conversa.

Al cas del grup d'experts en $\mathrm{Cl}$ s'utilitzen com a suport del debat unes frases extretes de Garabide Kultur Elkartea (2015-2016) sobre la utilitat i les múltiples aplicacions de la cooperació lingüística, per tal d'esbrinar si tenien coneixements previs sobre aquest tipus d'activitat i quina opinió els mereix (v. annex v). A més, cal recordar que en aquestes sessions, com a les entrevistes amb els experts en cooperació lingüística (v. 6.3.1.3), s'han utilitzat les frases extretes de les entrevistes realitzades a São Tomé i Príncipe traduïdes al castellà sobre la percepció dels entrevistats i les entrevistades envers la llengua (v. annex VI) i la subtitulació (v. annex VII).

Com ja s'ha esmentat, la tria de les frases de Garabide Kultur Elkartea (2015-2016) al grup de discussió amb experts en $\mathrm{Cl}$, pretenia sondejar els possibles coneixements d'aquests experts envers la cooperació lingüística, què n'opinen en termes generals i quant al cas particular de São Tomé i Príncipe, i si hi trobaven aplicacions alternatives (OS4).

Per últim, cal incidir en la utilitat de les frases extretes de les entrevistes a persones no ancianes, que pretenien oferir als experts una visió de quina és l'opinió d'aquestes persones envers la llengua i la subtitulació i generar una reflexió sobre si seria útil utilitzar la subtitulació de la manera que es proposa en aquesta tesi, de quina manera es podria fer i quins inconvenients hi hauria (OS4). L'opinió sobre aquestes qüestions de cadascun dels camps de treball dels experts ( $\mathrm{Cl}$, TAV i cooperació lingüística) ofereix una imatge més sòlida sobre quins serien els possibles escenaris que es podrien trobar en cas d'utilitzar la subtitulació de vídeos com a eina 
de cooperació activa per a la integració d'ancians o per a programes de revitalització lingüística (OP).

\subsubsection{Grup de discussió amb experts en $\mathrm{Cl}$}

Com es pot veure a la taula 10, aquest grup de discussió (conduït en castellà) està dividit en tres blocs temàtics: la cooperació lingüística, la cooperació lingüística a São Tomé i Príncipe i la subtitulació com a ferramenta de cooperació. El primer bloc temàtic d'aquest grup de discussió, dedicat a la cooperació lingüística, introdueix el terme i comença a recollir les primeres idees que evoca als participants. Cal recordar que, durant l'explicació de què és la cooperació lingüística (entre les preguntes 2 i 3), es parla del treball de l'ONG Garabide i es mostren algunes frases d'un document d'aquesta organització (Garabide Kultur Elkartea, 20152016) per a la seua valoració (annex v). Una vegada familiaritzats amb aquest terme, s'introdueix els participants a la situació particular de São Tomé i Príncipe, que alguns coneixien, però d'altres no. Durant aquest segon bloc, per tant, es tracta la cooperació lingüística a São Tomé i Príncipe, entenent-la com una hipotètica línia de treball al país. En aquest moment, s'exposa la situació lingüística i de les persones ancianes a São Tomé i Príncipe i, una vegada explicada, es recullen les primeres impressions sobre una possible cooperació lingüística en aquest context. Després s'explica detingudament quin ha sigut el treball desenvolupat al terreny per a aquesta tesi i se'ls convida a reflexionar sobre algunes frases extretes de les entrevistes aconseguides a São Tomé i Príncipe, també dividides en blocs temàtics. Com s'aprecia a la taula 10, el tercer bloc temàtic inclou la subtitulació i també s'acompanya de frases extretes de les entrevistes al terreny que hi feien referència. Per últim, els participants d'aquest grup de discussió valoren la utilitat en $\mathrm{Cl}$ d'una 
sèrie d'ítems proposats de l'1 al 10 essent 1 el valor més baix (inútil en $\mathrm{Cl}$ ) i 10 el més alt (utilitat essencial).

Taula 10. Guió del grup de discussió amb experts en $\mathrm{Cl}$ BLOC 1 RONDA DE PREGUNTES

1. ¿Sabéis qué es la cooperación lingüística?

2. ¿Conocéis algún proyecto de cooperación lingüística?

3. Creéis que la cooperación lingüística se debería tener más en cuenta en proyectos de $\mathrm{Cl}$ ?

$$
\text { APORTACIÓ D'INFORMACIÓ }
$$

Frases extraídas de Garabide Kultur Elkartea (2015-2016) (annex v)

\section{RONDA DE PREGUNTES}

4. ¿Pensáis que la cooperación lingüística sería útil en los países donde habéis trabajado?

BLOC 2

APORTACIÓ D'INFORMACIÓ

Explicación de la situación en Santo Tomé y Príncipe.

RONDA DE PREGUNTES

5. ¿Sería beneficiosa la cooperación lingüística en el caso particular de Santo Tomé y Príncipe? ¿Cómo se podría aplicar?

APORTACIÓ D'INFORMACIÓ

Explicación de la propuesta de la tesis y del ejercicio realizado en Santo Tomé y Príncipe. 


\section{RONDA DE PREGUNTES}

6. ¿Cómo valoráis el uso de la cooperación lingüística en Santo Tomé y Príncipe a partir de los siguientes testimonios, extraídos de las entrevistas realizadas en el terreno?

$$
\text { APORTACIÓ D'INFORMACIÓ }
$$

Testimonios de Santo Tomé y Príncipe sobre lengua (v. annex VI).

BLOC 3

RONDA DE PREGUNTES

7. ¿Pensáis que la subtitulación podría ser útil en proyectos de cooperación lingüística?

8. ¿Cómo valoráis el uso de la subtitulación en cooperación a partir de las siguientes frases, extraídas de las entrevistas realizadas en Santo Tomé y Príncipe?

APORTACIÓ D'INFORMACIÓ

Testimonios de Santo Tomé y Príncipe sobre subtitulación (v. annex VII).

RONDA DE PREGUNTES

9. ¿Qué dificultades supondría aplicar la subtitulación en este contexto?

10. ¿Qué otra utilidad podría tener la subtitulación en proyectos de cooperación?

BLOC 4 VALORACIÓ D'ÍTEMS

La cooperación lingüística debería tenerse más en cuenta en Cl.

La cooperación lingüística sería útil en alguno de los países en los que he trabajado. 
La cooperación lingüística sería útil en el caso particular de Santo Tomé y Príncipe.

La subtitulación sería una herramienta útil en el ámbito de la cooperación.

La subtitulación sería útil en proyectos de cooperación lingüística.

\subsubsection{Grup de discussió amb experts en TAV}

En aquest segon grup de discussió, el primer bloc temàtic es dedica a les possibles aplicacions alternatives de la TAV, la revitalització lingüística i la cooperació lingüística sense tindre informació prèvia sobre el tema de la tesi, més enllà de la seua relació amb la TAV. El segon bloc temàtic està dedicat al cas particular de São Tomé i Príncipe; per tant, és el moment d'informar els participants de la situació del forro i de les persones ancianes $i$ se'ls convida a reflexionar sobre les mateixes frases extretes de les entrevistes realitzades a São Tomé que ja es van mostrar al grup d'experts en $\mathrm{Cl}$ i que fan referència a la llengua i els ancians, la llengua i els sentiments i la llengua i l'educació ( $v$. annex $\mathrm{VI}$ ). Després, s'explica detalladament en què consisteix aquesta investigació i quin ha sigut el treball realitzat fins ara. Llavors, es dona pas al tercer bloc temàtic, dedicat a la reflexió sobre les possibilitats de la TAV a la $\mathrm{Cl}$ en São Tomé i Príncipe, i es mostren les frases extretes de les entrevistes que fan referència a la subtitulació ( $v$. annex VII). Per a finalitzar aquest grup de discussió, els participants valoren de l'1 al 10 (de nou, essent 1 el valor que indica més inutilitat i 10 el que indica una utilitat essencial) una sèrie d'ítems. En aquest grup, les intervencions són tant en castellà com en valencià. 
Taula 11. Guió del grup de discussió amb experts en TAV

BLOC 1 RONDA DE PREGUNTES

1. En quins àmbits es pot utilitzar la TAV més enllà del consum de productes audiovisuals estrangers?

2. I en $\mathrm{Cl}$ ? De quina manera podria ser?

3. Penseu que seria útil en projectes de revitalització lingüística?

4. Sabeu què és la cooperació lingüística? Se us ocorren usos de la TAV en cooperació lingüística?

\section{APORTACIÓ D'INFORMACIÓ}

Introducció a la situació de São Tomé i Príncipe i als testimonis de São Tomé i Príncipe sobre llengua

BLOC 2 RONDA DE PREGUNTES

5. Què opineu de les frases sobre les frases obtingudes a São Tomé i Príncipe?

6. En aquest context, quin paper penseu que podria tindre la subtitulació?

\section{APORTACIÓ D'INFORMACIÓ}

Explicació de la proposta de la tesi i de quin ha sigut el treball realitzat fins ara.

Testimonis de São Tomé i Príncipe sobre subtitulació. RONDA DE PREGUNTES

7. Què opineu d'aquestes frases? Us han sorprès?

8. Se us ocorre alguna idea de treball a São Tomé després del 
que heu llegit?

9. Quins problemes penseu que es trobarien si s'aplica la subtitulació en aquest país?

10. Seria possible aplicar alguna altra modalitat de TAV?

\section{BLOC 4} VALORACIÓ D'ÍTEMS

La TAV és útil en projectes de revitalització lingüística.

La TAV és útil en projectes de $\mathrm{Cl}$.

La subtitulació és útil al context particular dels ancians en São Tomé i Príncipe i el crioll forro.

Valora la utilitat de la subtitulació o SPS respecte d'altres modalitats que substitueixen la banda de diàlegs original (com el doblatge) en un context de revitalització lingüística.

Valora la utilitat de la subtitulació o SPS respecte d'altres modalitats que substitueixen la banda de diàlegs original (com el doblatge) en un context de $\mathrm{Cl}$.

\subsubsection{Notes de camp}

Com s'explica en l'apartat 3.2.1, les notes de camp són una eina per assolir els objectius d'una investigació etnogràfica, que San Vicente (2010) situa dins l'exercici de gravació i documentació. Recullen les experiències i les observacions de la persona encarregada de portar a terme la investigació (Emerson et al., 2013), que es consideren rellevants i no poden confiar-se a la memòria (McKernan, 1999). Aquest últim autor en distingeix quatre tipus: notes observacionals, notes conceptuals, notes personals i notes de procediments. Segons aquest autor, les notes observacionals consisteixen a descriure esdeveniments que s'han 
experimentat mitjançant l'escolta o l'observació de l'entorn. Quan les notes observacionals s'interpreten, passen a ser notes conceptuals, és a dir, notes que recullen el significat de les observacions. Les notes de procediments són apunts sobre el mètode de la investigació que es desenvolupa: posició de l'observador, el temps, l'accés a l'espai, les decisions que s'han hagut de prendre, etc. En aquesta tesi, les notes de camp es poden definir com notes observacionals, ja que es basen en l'anotació de comentaris dels entrevistats fora de càmera i que es considera rellevant per a la investigació, o d'informació rellevant per a comprendre les seues respostes. Més concretament, s'han recollit quatre notes de camp referents a les entrevistes de Fernando (persona anciana), Alda (entre 30 i 40 anys), Evaristo (entre 20 i 30 anys), Matilde (entre 30 i 40 anys), Alice i Amélia (ambdues entre 40 i 50 anys).

- Notes de Fernando: fora de càmera, abans d'iniciar la sessió, comenta que quan era jove participava al txiloli. En preguntar-li a l'entrevista, li costa explicar en què consisteix o com va ser la seua experiència (v. 7.1).

- Notes d'Alda: a les sessions d'adaptació dels subtítols amb Alda (6.5), explica el motiu pel qual Fernando li dona tanta importància al fet que abans els xiquets anaren nuets i se'ls permetera dinar amb les persones ancianes i l'explicació del significat de la cançó que canta Graça (v. 7.1). Després de gravar la seua entrevista, explica el cas de l'abandonament d'una persona anciana de la seua família i les reflexions que açò li suscita. Dos dies després d'aquesta entrevista, explica les idees que li genera l'exposició a material en forro subtitulat: la possibilitat que s'emeta un programa infantil en forro subtitulat. 
- Notes d'Evaristo: es mostra molt molest front al prejudici que tots els joves maltracten les persones. És important recordar que Evaristo va viure amb la seua àvia, que ella el va criar fins que va morir i per qui tenia una gran estima. Aquesta informació es va obtindré temps enrere, ja que Evaristo era una de les amistats personals amb qui es va comptar (6.6).

Notes de Matilde: dies després d'haver entrevistat Matilde, durant un encontre fortuït, va explicar que havia reflexionat sobre el que s'havia parlat a l'entrevista i concloïa que són més els homes considerats curanderos (que implica una connotació positiva) que les dones, que són més habitualment acusades de fetilleres (connotació negativa).

- Notes d'Alice: només acabar la seua entrevista, explica que, després de tants anys al país, el motiu pel qual no considera que coneix bé la seua cultura és que mai ha arribat a aprendre forro .

- Notes d'Amélia: durant el comiat després de finalitzar l'entrevista, explica que l'exercici realitzat li havia fet adonar-se que hauria d'aprofundir més en molts aspectes culturals del seu país i, sobretot, iniciar els seus propis fills, que tenen un gran desconeixement.

\subsection{MÈTODE D’ANÀLISI DE DADES}

Existeixen diferents metodologies per a estudiar una realitat social: la quantitativa i la qualitativa. Mentre que 
la metodologia quantitativa busca explicar fenòmens a través de la identificació de lleis generals que expliquen el comportament social, la qualitativa busca comprendre el significat dels fenòmens socials $i$ no només explicar-los (Monje, 2011).

Segons Monje (2011), les investigacions qualitatives parteixen de dades per a desenvolupar comprensió, conceptes i teoria; compten amb una interacció amb informants mitjançant les entrevistes; intenten comprendre les persones dins el seu context; consideren les persones, els escenaris i els grups com un tot; no busca la veritat sinó les perspectives de l'actor social i centren l'anàlisi en la descripció i l'observació de fenòmens. La tesi que es presenta és una investigació qualitativa perquè s'adapta a la descripció d'aquest autor: parteix de les dades teòriques que s'exposen als capítols 1, 2, 3, 4 i 5 per a desenvolupar comprensió, conceptes i teoria sobre les possibilitats d'utilitzar la TAV com a eina de cooperació al context de São Tomé i Príncipe; s'han realitzat entrevistes; totes les persones participants i el context d'aquestes es consideren part d'un tot que permet extraure una sèrie de conclusions (v. 8); es busca la perspectiva d'aquests agents, etc.

L'anàlisi de dades qualitatives implica buscar temes comuns al conjunt d'informació que es recull al treball de camp mitjançant les tècniques descrites en l'apartat 3.2. Aquests temes comuns s'identifiquen després de categoritzar (simplificar el contingut a categories segons temàtiques d'interès per a la investigació) i codificar la informació (Sabariego-Puig et al., 2014). Huberman i Miles (1994) proposen tres mètodes per fer aquest tipus d'anàlisi:

- La reducció de dades. Es pot fer anticipadament, quan es defineixen les preguntes, se seleccionen els 
participants i els instruments, etc.; o després d'haver recol-lectat les dades mitjançant resums, codificacions, etc.

- La presentació de dades. Està orientada a facilitar la mirada reflexiva de l'investigador mitjançant resums, diagrames, croquis, etc.

- L'elaboració de conclusions. S'utilitzen comparacions, assenyalament de patrons i temes i la triangulació (entre altres tècniques) per a extraure els significats de les dades recollides.

En aquesta tesi, la reducció de dades s'ha realitzat després d'haver-les recol-lectat, mitjançant codificacions que, com indiquen González i Cano (2010), permeten condensar-les en unitats analitzables i, gràcies a aquesta condensació, s'han pogut relacionar temes que sorgien a les diferents intervencions de les persones participants. Ja que a les investigacions qualitatives solen recollir-se una gran quantitat de dades de forma auditiva, textual o audiovisual, resulta indispensable comptar amb el suport d'un programari informàtic per a facilitar la sistematització i el control de l'anàlisi de dades (Rodríguez Sabiote et al., 2005). En aquesta tesi s'ha fet ús de l'Atlas.ti, un programari especialitzat en l'anàlisi qualitativa de dades. Permet extraure, categoritzar i vincular segments de dades, així com afegir etiquetes que classifiquen la informació segons els codis que siguen més útils per a la investigació (Sabariego-Puig et al., 2014). En aquest cas, la ferramenta Atlas.ti ha permés afegir arxius amb la transcripció de totes les entrevistes i les intervencions dels grups de discussió i la selecció de les parts més importants per a la investigació codificantles per temàtiques (v. 7.2, 7.3.1, 7.3.2 i 7.3.3), de manera que es facilita la tasca d'identificar els resultats més substancials, interpretar-los i extreure'n conclusions (v. 8). El programa ofereix la 
possibilitat de consultar les codificacions per separat o cada transcripció completa, la qual cosa agilitza el procés d'anàlisi.

Rodríguez Sabiote et al. (2005) recomanen que la presentació de dades es base en la descripció, la interpretació, el recompte i la concurrència de codis, i en la comparació i la contextualització d'aquests. Aquest exercici s'ha realitzat mitjançant resums organitzats ( $\mathrm{v}$. annexos V, VI i VII) i taules (v. índex de taules), i se centra en l'organització de la informació que s'ha codificat anteriorment, establint relacions entre diferents tipus de dades per a facilitar les comparacions de les quals sorgeixen les interpretacions de les dades (González i Cano, 2010). A partir d'aquesta tècnica, es distribueixen temàticament els resultats de les entrevistes i els grups de discussió (v. 7) i les conclusions d'aquests resultats (v. 8).

Les conclusions s'han extret, com recomanen Rodríguez Sabiote et al. (2005), mitjançant una estada prolongada al terreny (v. 6.6), la consolidació teòrica (v. 1, 2, 3, 4 i 5 ), la triangulació de dades (en aquesta cas amb els participants experts, v. 3.2.2), les connexions entre respostes de diferents participants establertes a les codificacions de reducció de dades (v. 7 i 8), i la comparació d'algunes de les respostes recollides (v. 8).

\subsection{SUBTITULACIÓ ADAPTADA DEL VÍDEO}

La realitat de São Tomé i Príncipe dista molt de la d'Europa en termes de nivell cultural a causa de les carències en l'ensenyament i la falta d'accés a llibres (v. 5.2), la qual cosa marca necessàriament una diferència en la velocitat i la comprensió lectora. Per tant, les convencions de subtitulació que s'han detallat 
en l'apartat 2.2, tot i resultar útils com a punt de partida, han d'adaptar-se a les necessitats específiques del país. En concret es proposen canvis en les convencions espacials i temporals, com veurem més endavant.

Per tal d'aconseguir-ho, es va comptar amb l'ajuda de la primera entrevistada (que pertany al grup de natius entre 30 i 40 anys) a qui anomenem Alda: una treballadora domèstica amb estudis bàsics i sense hàbit de lectura. El seu coneixement de forro és passiu: l'entén sense dificultat, però reconeix no haver-lo parlat fins ara, que comença a atrevir-se a utilitzar-lo tímidament amb persones majors, tot i que en un principi l'havia definit com la seua llengua materna.

Es va escollir utilitzar Alda com a referent perquè té un perfil comú amb moltes persones a São Tomé i Príncipe: estudis molt bàsics i sense hàbit de lectura per falta d'accés a material (v. 5.2). A més, es troba en una edat mitjana entre els més joves i més majors que es pretenia entrevistar.

Una vegada es va editar i preparar el vídeo que es mostraria als entrevistats i les entrevistades sobre el testimoni de les persones ancianes, es va visionar amb Alda amb les convencions de subtitulació explicades a l'apartat 2.2. En base a aquests primers subtítols, Alda expressava les dificultats que trobava, que es podrien resumir en falta de temps per llegir i processar-ne el contingut. La informació es va resumir al màxim i també es va allargar el temps que estaven en pantalla progressivament, segons les necessitats i les observacions d'Alda, fins que aquesta va confirmar que podia llegir-los còmodament i amb temps suficient de mirar les imatges. De vegades, açò suposava una falta de sincronia amb la imatge, però es va decidir que primara la 
informació més rellevant del text oral i, en conseqüència, s'han creat uns subtítols adaptats a la velocitat de lectura dels espectadors.

El resultat es caracteritza per uns subtítols desiguals, ja que tant la llargària com el temps que estan en pantalla depenen de la velocitat i la dificultat del discurs de cada ancià. Cap dels posteriors entrevistats, però, va tindre dificultats a llegir els subtítols, ni tan sols els que no sabien forro o tenien un coneixement molt limitat, que era el que es pretenia amb aquestes adaptacions. A continuació es mostren taules comparatives de les convencions generals de subtitulació junt amb les convencions adaptades a São Tomé i Príncipe. Per a cada convenció, s'explica quin ha sigut el canvi necessari i s'especifica «sense modificacions» en els casos que s'ha pogut mantindre la convenció original. Algunes de les convencions explicades a l'apartat 2.2 no hi consten perquè no han sigut objecte d'adaptació, donat que no eren necessàries pel contingut del vídeo.

A la taula 12 (convencions espacials) es pot apreciar la diferència que hi ha als caràcters per línia: mentre que les convencions generals indiquen entre 28 i 49 caràcters per línia, en l'adaptació per a São Tomé i Príncipe són d'un màxim de 39.

Taula 12. Convencions espacials

CONVENCIONS ESPACIALS

CONVENCIONS ESPACIALS STP

Subtítols a la part inferior de la pantalla

Sense modificacions

Màxim dues línies

Sense modificacions

28 - 49 caràcters per línia

39 caràcters per línia 
A la taula 13 es mostren les convencions temporals. Destaquen els cps, entre 10 i 14 a les convencions generals, però amb un màxim de 13 a l'adaptació. Els subtítols es mantenen més temps en pantalla si és necessari per la llargària o la dificultat del discurs, encara que el diàleg ja haja finalitzat. Per exemple, al minut 0:02:50.68, el subtítol apareix quan l'anciana que parla comença a dir la frase Todo o que temos é a nossa língua. Aquesta frase acaba al minut 0:02:53.84, però el subtítol corresponent es manté en pantalla fins el minut 0:02:54.60.

Taula 13. Convencions temporals

CONVENCIONS TEMPORALS

Subtítols entren i ixen en sincronia amb els diàlegs

Subtítols entre 10 i $14 \mathrm{cps}$
CONVENCIONS TEMPORALS STP

Els subtítols es mantenen més temps en pantalla, encara que haja acabat la intervenció

Subtítols entre 3 i $13 \mathrm{cps}$

\section{Les convencions ortotipogràfiques s'han} mantingut. Alguns aspectes no es representaven a les intervencions dels vídeos i, per tant, no ha sigut necessari incloure-les.

Taula 14. Convencions ortotipogràfiques

\begin{tabular}{cc}
\hline CONVENCIONS & CONVENCIONS \\
ORTOTIPOGRÀFIQUES & ORTOTIPOGRÀFIQUES STP \\
\hline Punt (.) quan el subtítol s'acaba & Sense modificacions \\
\hline No s'eliminen signes de puntuació & Sense modificacions
\end{tabular}


Allò que més destaca de les convencions lingüístiques (taula 15) és la quantitat d'informació de la qual es prescindeix al vídeo per facilitar la lectura dels subtítols. Per exemple, al minut 0.06.46.72 una de les ancianes explica durant 35 segons la celebració del Bokadu. Especifica les persones que hi participen, com es prepara la taula, quin és el menjar que comparteixen, la cançó que s'hi canta i de quina manera se celebra amb detall. Als subtítols es va simplificar notablement la seua explicació:

0:06:46.72 - 0:06:57.94

No dia do Bokadu, se põe a comida, as frutas...

Chama-se a tudo o mundo.

0:07:00.00 - 0:07:06.14

Se estende uma esteira...

0:07:07.44-0:07:17.98

...e sentam-se todos à volta da mesa.

O mais velho dá a comida um a um.

0:07:18.00 - 0:07:22.42

Depois se canta uma canção ao Senhor.

Als subtítols no apareixen tots els aliments de què parla, ni la lletra de la cançó ni molts detalls específics d'aquesta celebració. Es va considerar necessària aquesta reducció per fer prevaldre el respecte a la velocitat de lectura de les persones que veurien el vídeo més endavant i només es va mantindre la 
informació més rellevant que es corresponia amb la gestualitat de l'anciana al vídeo.

Taula 15. Convencions lingüístiques

CONVENCIONS LINGÜÍSTIQUES

CONVENCIONS LINGÜÍSTIQUES STP

Respecte a les unitats gramaticals

Sense modificacions

Resumir la informació del text oral

Es sintetitza considerablement més que a les convencions originals, per poder deixar el subtítol més temps en pantalla. Aquest resum implica omissions, condensacions i reformulacions

Respectar els matisos idiomàtics $i$ les referències culturals de l'original

Els subtítols no contradiuen les imatges

Subtítols sincronitzats amb les imatges
Es resumeixen quan es tracta d'enumeracions per afavorir el temps de lectura

Sense modificacions

Lleugera asincronia amb les imatges al final de cada intervenció, ja que els subtítols es mantenen més temps en pantalla. 


\subsection{TEMPORITZACIÓ}

A causa de la quantitat d'informació que es presenta pel que fa a les persones participants, les dades recollides $i$ els temps i les localitzacions en que s'han portat a terme, és necessari dedicar un apartat a la temporització de la metodologia d'aquest treball.

Un cop finalitzada la tasca més teòrica que implica la base bibliogràfica i un primer esborrany del projecte, durant els mesos de setembre i octubre de 2016 es va realitzar una primera estada a l'illa de São Tomé, concretament al districte d'Água Grande, per a establir un primer contacte amb les persones encarregades del centre d'ancians de la ciutat on es pretenia entrevistar els participants ancians en aquesta tesi. També es va aprofitar per a prendre notes sobre les possibilitats i les dificultats que es detectaven per a la realització de la investigació i es va establir contacte amb alguns dels participants no ancians a qui s'entrevistaria més endavant (Alda, Alice, Evaristo i Élio). En el cas d'Alda, es va acordar la seua col-laboració per a la subtitulació del vídeo dels ancians (v. 6.3.1).

Amb aquesta informació es va poder realitzar una planimetria (v. 3.2.1) de la part de la investigació que es desenvoluparia al terreny, es va ajustar i consolidar la idea inicial del projecte i es van dissenyar les entrevistes a les persones ancianes $i$ alguns dels aspectes de les entrevistes a persones no ancianes (les entrevistes concretes d'aquest grup no es van consolidar fins no tindre el vídeo amb el testimoni de les persones ancianes). 
Els mesos de març $\mathrm{i}$ abril de 2018 es va realitzar la segona estada a São Tomé per a gravar les entrevistes a persones ancianes (al centre amb el qual s'havia contactat l'any 2016), es van editar les gravacions fins crear el vídeo final amb les seues intervencions i es va preparar la subtitulació adaptada. Amb aquest material, es van acabar de perfilar les entrevistes a persones no ancianes que es van realitzar al llarg del mes d'abril en diferents emplaçaments: cases particulars dels entrevistats o entrevistades $i$ espais cedits, com aules d'escola en horari no lectiu, la sala d'un local d'una ONG, i un establiment particular fora de l'horari de treball. Es va continuar amb la tasca de les notes de camp per tal de completar les entrevistes amb apreciacions que els participants expressaven fora de càmera.

Al mes d'abril de 2019, aprofitant les $V I$ Jornadas de Voluntariado Internacional que es realitzaven a l'extensió universitària de la Universidad de León a Ponferrada, es va realitzar el primer grup de discussió, amb experts en $\mathrm{Cl}$. Al llarg del mes es va transcriure i codificar el resultat obtingut.

Al juny de 2019 es va realitzar el segon grup de discussió, amb experts en TAV, a la Universitat de València aprofitant una estada en aquesta universitat. També es va transcriure i codificar la gravació resultant. Per últim, durant el mes de juliol de 2019 es van realitzar les entrevistes als dos experts en cooperació lingüística a través d'Skype (ja que la disponibilitat dels entrevistats i les seues residències en aquell moment impossibilitaven la realització d'un grup de discussió o entrevista presencial), i la transcripció i la codificació d'aquestes sessions.

Per a visualitzar millor aquesta informació, a continuació es presenta una taula resum de la temporització d'aquesta investigació amb la data en què es va realitzar cada 
activitat, el lloc on s'hi va desenvolupar, els instruments emprats i els exercicis concrets que es van realitzar, a més de l'equivalència d'aquestes activitats amb la proposta de pla d'acció de San Vicente (2010), desglossada en l'apartat 3.2.1. En aquesta taula no s'inclouen la reflexió, documentació i bibliografia (tot i haver-los realitzat), ja que aquests exercicis es van realitzar abans de cada viatge al terreny.

Taula 16. Temporització de la investigació

DATA

LLOC

INSTRUMENTS

EXERCICI
EQUIVALÈNCIA AMB

SAN VICENTE (2010)

\begin{tabular}{|c|c|c|c|c|}
\hline $\begin{array}{l}\text { Setembre i } \\
\text { octubre de } 2016\end{array}$ & $\begin{array}{l}\text { Districte d'Água } \\
\text { Grande (São } \\
\text { Tomé). }\end{array}$ & Notes de camp. & $\begin{array}{l}\text { Primer contacte } \\
\text { amb el centre de } \\
\text { persones ancianes, } \\
\text { i amb Alda, Alice, } \\
\text { Evaristo i Élio. }\end{array}$ & $\begin{array}{l}\text { Planimetria, } \\
\text { observació } \\
\text { participant. }\end{array}$ \\
\hline
\end{tabular}

Març i abril de 2018

Abril de 2019

Juny de 2019

Districte d'Água
Grande (São
Tomé): centre de
persones
ancianes, cases
particulars,
espais cedits
(escoles, espai
d'ONG i
establiments
particulars).

Entrevistes (a les persones ancianes i a les persones no ancianes) i notes de camp.
Realització i preparació de les entrevistes, edició del vídeo amb les contribucions de les persones ancianes i l'adaptació de la subtitulació.
Planimetria, treball de camp, entrevistes, gravació i documentació, observació participant, informe i conclusions.

\section{Extensió universitària de la Universidad de León, Ponferrada. \\ Grup de discussió amb els participants experts en $\mathrm{Cl}$. \\ Gravació del grup de discussió, transcripció i codificació amb l'Atlas.ti.}

Universitat de València.

\section{Grup de} discussió amb experts en TAV.
Gravació del grup de discussió, transcripció i codificació amb
Entrevistes, gravació i documentació, informe $\mathrm{i}$ conclusions.
Entrevistes, gravació i documentació, informe i 
Entrevistes amb experts en cooperació lingüística.
Connexió telemàtica via Skype.
Juliol de 2019
l'Atlas.ti.
Gravació de les entrevistes, transcripció i codificació amb l'Atlas.ti.

conclusions.
Entrevistes, gravació i documentació, observació participant, informe i conclusions.

Com es pot veure, totes les iniciatives que conformen la metodologia d'aquesta investigació ofereixen diferents punts de vista del mateix escenari: la de les persones de São Tomé, que aporten la seua visió des del terreny sobre la situació del forro i de les persones ancianes i l'acceptació d'un producte audiovisual en forro subtitulat sobre aquests temes; la dels experts en $\mathrm{Cl}$, que aporten possibles aplicacions, problemes i beneficis del que es proposa en aquesta tesi; els traductors, que amplien les possibilitats i usos de la TAV en aquest cas; i els experts en cooperació lingüística, que valoren la implementació de la subtitulació com a ferramenta innovadora en projectes de revitalització lingüística. Les respostes recollides a les participacions de totes aquestes persones $\mathrm{i}$ grups d'experts conformen els resultats d'aquesta investigació, que s'exposen al següent capítol. 


\section{RESULTATS}

En aquest capítol s'exposen els resultats de la investigació que presenta aquesta tesi i que responen als objectius plantejats al seu inici. Primerament, es troben les participacions de les persones de São Tomé i Príncipe, tant ancianes com no ancianes (les opinions d'aquest segon grup es divideixen segons l'edat dels participants). A continuació, l'opinió dels experts en $\mathrm{Cl}$, TAV i cooperació lingüística segons una sèrie de temàtiques seleccionades de les seues intervencions per la seua rellevància per a aquest estudi. Com s'esmenta a l'apartat 6.2, a tots els participants (persones ancianes, persones no ancianes i experts) se'ls ha assignat un pseudònim per a fer referència a les seues intervencions preservant el seu anonimat.

\subsection{Resultats DE LES ENTREVISTES A PERSONES ANCIANES DE SÃO TOMÉ}

Les entrevistes realitzades a les tres persones ancianes de São Tomé que es descriuen a continuació, són una mostra de les seues percepcions sobre la temàtica sociolingüística i cultural que motiva aquesta investigació. Els resultats que se n'extrauen es basen en la informació que es recull al vídeo final que es va mostrar a les persones no ancianes, ja que es tracta d'un resum amb les parts més substancials de l'entrevista completa (v. annex II). La transcripció en portuguès, a partir de la qual s'analitza el contingut d'aquestes entrevistes està numerada per paràgrafs per facilitar la consulta a la font original, que es pot trobar en l'annex I. El nom dels documents que conté aquesta carpeta 
coincideix amb el nom que s'ha assignat a les tres persones ancianes entrevistades: Fernando, Graça i Juliana.

A la seua entrevista, Fernando explica que les danses tradicionals ja no es fan com abans (paràgraf 14) ni amb els instruments que se solien tocar (paràgraf 17). Fora de càmera, havia comentat que quan era jove participava al txiloli però, en preguntar-li a l'entrevista, li resulta complicat explicar en què consisteix o com va ser la seua experiència (paràgrafs 20-23). En canvi, sí que diu que era una celebració que seguien moltes persones i que ara ja no interessa (línia 26). També enumera altres tradicions que considera que estan desapareixent: el dansu-kongô, l'uswa, la ladenha (paràgraf 32).

Fernando també parla de com era la situació dels ancians quan ell era un xiquet. Explica que era habitual que les mares encarregaren als fills que portaren una ració del dinar a alguna persona anciana. Aquesta persona també oferia menjar al xiquet i li'n donava perquè el compartira amb la seua família (paràgraf 41).

Segons conta, quan els xiquets es portaven malament a casa dels ancians, aquests podien assotar-los amb una vara; després els donaven la vara als xiquets perquè la portaren a casa i els l'ensenyaren als seus pares, que entenien que no s'havien comportat bé amb els ancians i els tornaven a castigar (paràgrafs 43 i 44). Durant la preparació del vídeo que es mostraria d'aquestes entrevistes, Alda va explicar que el motiu pel qual Fernando emfatitza tant el fet que abans s'enviara els xiquets amb dinar per als ancians i se'ls permetera dinar amb ells, és que actualment els pares ho prohibeixen als fills per por que el menjar estiga enverinat. Segons el seu testimoni, pot passar que si un xiquet es posa malalt i 
anteriorment havia acceptat menjar d'alguna persona anciana, s'acuse aquesta persona d'haver-li volgut fer mal a propòsit.

Com diu Fernando, es pensa que les persones ancianes sospitoses de fetilleria poden fer mal als xiquets i es lamenta sobre el fet que, antigament, els xiquets podien anar nuets i ara està mal vist (paràgraf 50). De nou, en aquest cas resulten de gran importància els comentaris d'Alda, que explica que a São Tomé i Príncipe pensen que el mal d'ull entra per l'esquena. Per tal que les persones majors, gelosos de joventut dels infants, no els llencen mal quan els passen de llarg, els xiquets han d'anar vestits per a tindre l'esquena coberta i que el mal d'ull no els puga afectar. Fernando recorda que, si algun xiquet furtava fruits de l'hort d'algun ancià, l'ancià li pegava amb la vara com a càstig. Si un ancià castiga d'alguna manera a un xiquet ara, poden arribar a matar-lo. Diu que fins i tot un pare ancià pot acabar mort a mans d'un fill (paràgraf 58).

Fernando reconeix que, per una banda, abans tenien més carències en termes de pobresa però que, per una altra banda, hi havia molt de respecte i es considerava que «els ancians eren els déus del món ${ }^{17}$ ». De fet, segons conta, era costum parlar a les persones ancianes amb la mà al pit com a senyal de respecte (paràgraf 52 ).

Sobre la qüestió lingüística, Fernando diu que, quan era jove, només parlava forro. Quan van nàixer els seus fills, però, els va criar en portuguès i, ara que són adults, no saben parlar forro (paràgraf 72). A la pregunta de per què va prendre 
aquesta decisió, respon que dues de les seues filles han estudiat i que no es pot estudiar forro (paràgraf 75). En canvi, quan se li pregunta si li agradaria que s'estudiara forro a les escoles, diu que sí, perquè també s'haurien d'aprendre les coses de São Tomé (paràgraf 69).

Graça es mostra orgullosa d'haver anat a l'escola i arribar fins a quart (v. 5.3), i explica que va aprendre forro d'adulta (paràgraf 10). Segons conta, a mesura que creixia, sentia parlar forro als adults i, en canviar la seua forma de pensar infantil a una forma de pensar adulta, va començar a parlar forro, ja que, segons ella, és la llengua dels adults (paràgraf 13). Als seus fills, en canvi, els va criar en portuguès. En la seua opinió, aquesta és la llengua en què s'ha de parlar als xiquets; als adults, forro (paràgraf 26).

Canta una cançó tradicional que solia escoltar-se molt antigament: l'aigua es pot assecar, però el seu nom no s'acaba. Recordem allò que hem viscut en el passat, recordem el que vivim (paràgraf 20). Pel que fa a altres tradicions, com les danses, Graça explica que ara els joves també saben ballar-les, però ho fan per guanyar concursos (paràgraf 23).

A la reflexió final de com viuen les persones ancianes ara, Graça parla en relació amb la pobresa i en fa una lectura positiva, sense entrar a valorar quina és la seua situació social. Es mostra agraïda per l'ajuda que reben a São Tomé i Príncipe d'ONG d'altres països (paràgraf 35).

Juliana parla portuguès amb certa dificultat. Explica que, quan era menuda, normalment parlava en forro, encara que va aprendre un poc de portuguès perquè era la treballadora domèstica d'una família portuguesa (paràgraf 6 ). Els seus fills, en 
canvi, sí que parlen ambdues llengües, ja que ella els va ensenyar forro i, en l'actualitat, de vegades parlen en portuguès i de vegades en forro (paràgraf 46).

En preguntar-li per històries, cançons o costums que s'han perdut o s'estan perdent, Juliana canta una cançó (paràgraf 9) que els joves ja no coneixen (paràgraf 13). També parla de les danses i el Bokadu. Sobre les danses, aprecia que ara els joves ixen a ballar a les nits quan volen i tenen llibertat d'oci, mentre que, quan ella era jove, això estava prohibit. A banda d'açò, considera que les danses d'ara no tenen res a veure a la forma en què es ballava abans, però no entra en detalls (paràgraf 28). Pel que fa al Bokadu, Juliana explica que se celebra Dimecres de Cendra. S'ha de comprar peix i fumar-lo per a preparar kalu (o calulu) i també es prepara angu, una pasta feta de plàtan. Quan ja està tot a punt, la família s'asseu sobre una estora i la persona més anciana dona el dinar a la resta d'un en un, del més major al més menut. Després canten junts una cançó. En canvi, ara cadascú cuina el seu dinar i mengen a taula com un dia normal (paràgraf 32). Juliana pensa que la forma tradicional de celebrar el Bokadu s'està perdent, perquè els fills ja no visiten les mares, ni tan sols en dies assenyalats (paràgraf 39 ).

A partir d'aquestes contribucions (v. annex I) es van seleccionar algunes de les intervencions dels tres ancians per crear el vídeo de 12 minuts (v. annex ॥) sobre el qual es va entrevistar posteriorment a la resta de participants de São Tomé. En aquest vídeo es buscava la presència de temàtiques com la llengua, la cultura i les tradicions, i el tracte a les persones ancianes com es detalla a continuació.

Pel que fa a la llengua, es desprén, d'una banda, la idea que el forro és una llengua que es parla en família 
(min. 02.34). D'altra banda, però, també que la llengua per a dirigirse als xiquets és el portuguès i que el forro es parla una vegada es fan adults (min. 03.15, 03.29 i 03.44). Aquesta és una generació que ja ha parlat portuguès als seus fills, tot $i$ tindre com a llengua materna el forro (min. 03.15 i 03.34). Tot i això, Fernando, per exemple, expressa el seu desig que s'estudie forro a les escoles (min. 03.57).

En l'àmbit cultural, tant Graça com Juliana donen exemples de cançons populars que ja no se senten $(04.37 \mathrm{i}$ 04.55) i els tres troben diferències tant en la motivació com en la metodologia de les danses tradicionals. Per a Fernando, ara es realitzen de forma diferent, sense utilitzar instruments tradicionals que abans sí que s'utilitzaven (min. 05.29 i 06.16); per a Graça, la diferència està en el fet que ara es balla per a participar en concursos i guanyar premis (min. 06.01); Juliana veu que aquestes danses ja no són les que es ballen per a divertir-se, perquè ara els joves poden anar a discoteques i tenen més llibertat durant el seu temps d'oci ( $\min .10 .37)$.

Juliana i Fernando són els que més acusen una pèrdua d'interès per les tradicions del país i donen l'exemple del Bokadu (min. 06.46) i d'altres representacions culturals que consideren que estan desapareixent, com el dansu-kongô, l'uswa i la ladenha, que Fernando dona per perduda (min 08.58).

Quant al tracte que reben els ancians, Juliana parla de la família i de com els fills no es preocupen de visitar els pares (min. 07.37); Fernando és més genèric i conta com recorda que era el tracte als ancians quan ell era menut: el veïnat solia enviar els xiquets a oferir-los menjar, se'ls tenia un gran respecte i se'ls considerava els déus del món. Fins i tot hi havia l'hàbit de parlar-los amb la mà al pit com a senyal de respecte. Actualment, 
però, assenyala les acusacions de fetilleria i parla, fins i tot, de maltractament físic (min. 11.40 i 12.10).

\subsection{Resultats de LES ENTREVISTES A PERSONES NO ANCIANES DE SÃO TOMÉ}

Les entrevistes a persones no ancianes de São Tomé pretenien que els participants no ancians expressaren la seua visió personal sobre la situació dels ancians i del crioll forro, esbrinar si l'exposició al vídeo dels ancians els convidava a la reflexió i testar l'acceptació del material audiovisual en forro subtitulat en portuguès. Per tant, els resultats de les entrevistes s'han estructurat al voltant d'aquests eixos (v. 6.4), que es corresponen amb els objectius secundaris 2 i 3 (v. 8.3):

1. Apreciació de la llengua

2. Apreciació dels ancians

3. Apreciació de la cultura del país

4. Apreciació de la subtitulació

5. Relació entre la situació dels ancians, la llengua i la cultura del país

6. Possibles accions

Per facilitar l'anàlisi de les respostes al context sociocultural de São Tomé i Príncipe i tenint en compte el conflicte generacional que es viu al país, els resultats obtinguts es divideixen segons les edats dels participants. Cal recordar que 
aquestes entrevistes es realitzen en dues fases (v. 6.3.1.1): una primera, en la qual se'ls fa preguntes generals sobre el forro, la cultura i les tradicions del país i la vida de les persones ancianes; i una segona, després de veure el vídeo de Graça, Fernando i Juliana subtitulat, per analitzar qualsevol reflexió o canvi de percepció sobre les mateixes qüestions, a més d'esbrinar l'opinió que els genera l'exposició als subtítols. Encara que la informació es presenta per categories temàtiques i no cronològicament als consegüents subapartats, a la conclusió es dedica un paràgraf als canvis observats en algunes de les persones entrevistades després de veure el vídeo. La transcripció d'aquestes sessions, a partir de la qual s'extrauen les categories presentades anteriorment, poden consultar-se en l'annex III. El títol dels documents coincideix amb el nom assignat a cada participant no ancià de São Tomé i Príncipe: Alda, Alice, Amanda_Miguel_Abigail_Flávia_Mafalda_António, Amélia, Deolinda, Diogo, Élio, Elmer, Evaristo, Matilde i Wilson.

\subsubsection{Menors de 20 anys}

Dins aquest grup es troben Abigail i Flávia (pediatres tradicionals), Miguel (atleta) i Elmer (estudiant). Cal recordar que Abigail, Flávia i Miguel van manifestar que la seua llengua materna és el forro (paràgrafs 91-93) tot i que, més endavant, Abigail (paràgraf 313) diu que només l'entén i sap dir algunes coses. També és important saber que l'apreciació de les persones ancianes d'Abigail i Flávia segurament està condicionada per la seua professió, ja que són els més majors qui els ensenyen els remeis tradicional (paràgrafs 44 i 62). Per la seua part, Elmer reconeix no parlar ni entendre el forro, ni tampoc coneix les circumstàncies en les quals se sol parlar (paràgraf 35 ), perquè no està en contacte amb aquesta llengua en el seu dia a dia (paràgraf 31). Tenint presents les dades anteriors, a continuació s'exposen les respostes donades per aquest grup. 


\section{Apreciació de la llengua}

Abans de veure el vídeo, se'ls pregunta quina és la millor llengua per fer gestions, anar al metge, etc. Tots responen que el forro (paràgrafs 130-138) excepte Elmer, que opina que és el portuguès (paràgraf 33 ). Abigail relaciona el forro clarament amb els vells, ja que pensa que és la llengua en què ells prefereixen expressar-se (paràgraf 151).

Després de veure el vídeo, els quatre expressen que els agradaria que el forro s'estudiara a l'escola (paràgrafs 297, 299 i 301). Fins i tot Elmer, que no parla ni entén forro, coincideix en aquesta visió (paràgrafs 73-74). En aquesta línia, els quatre joves també diuen que els agradaria que hi haguera més programació en forro (paràgrafs 295, 299 i 301). Elmer, de fet, justifica aquesta resposta perquè creu que la presència del forro als mitjans de comunicació ajudaria els joves a aprendre la llengua (paràgraf 78).

Pel que fa als motius pels quals els pares ja no transmeten el forro als fills, cadascun dona un motiu diferent: Abigail diu que és difícil parlar forro correctament perquè està desapareixent, ja que sovint es barreja amb el portuguès, que és la Ilengua que parla la majoria (paràgraf 313); Flávia pensa que als xiquets els resultaria difícil d'entendre (paràgraf 311); Miguel que es deu a un desinterès generalitzat de la societat per aprendre la llengua i que, aleshores, els xiquets creixen amb aquest desinterès (paràgraf 315); per a Elmer el motiu és que la llengua no s'estudia a l'escola (paràgraf 80). 


\section{Apreciació dels ancians}

Flávia diu que la discriminació als ancians es troba sobretot a les classes més baixes (paràgraf 167). Elmer creu que, tot i que depén de cada família, a la majoria se'ls abandona i que de vegades ni tan sols les institucions els donen el suport que necessiten (paràgraf 37 ).

Miguel diu que algunes persones no s'acosten a algú que està parlant amb una persona anciana (paràgraf 203). Flávia comenta que en algunes ocasions és evident que necessiten ajuda i ningú s'acosta a ells; que de vegades se'ls insulta (fins i tot alguns xiquets) i maltracta (paràgraf 201). Creu que els vells tenen vergonya de parlar amb els joves, perquè alguns els acusen de voler-los xuclar la sang (paràgraf 332).

Abigail observa que no totes les persones participen d'aquestes discriminacions i que algunes intenten ajudarlos sempre que poden. Considera que les persones ancianes són la saviesa de la terra (paràgraf 166).

Elmer troba important deixar-se instruir pels més majors, però no creu que la majoria dels seus amics opinen com ell (paràgrafs 88-90).

Apreciació de la cultura del país

Pel que fa als aspectes culturals que es comenten al vídeo i pels quals se’ls pregunta, Flávia i Miguel els reconeixen tots; Abigail també excepte els chocalhos (paràgrafs 170187) i Elmer només coneix les danses i el txiloli (paràgrafs 38-50).

Quant a les cançons que es canten al vídeo, només Miguel coneixia les dues (paràgraf 273) i Elmer, per contra, 
no en coneixia cap i reconeix que algunes representacions culturals del país s'estan perdent (paràgrafs 72 i 82). Abigail no tenia clar si el seu fill les havia sentides o no (paràgraf 271), mentre que Flávia pensa que no les coneixerà fins que no tinga l'edat suficient (paràgraf 265).

\section{Apreciació de la subtitulació}

Encara que Miguel és l'únic que diu no haver tingut la necessitat de llegir-los (paràgraf 235), ni Flávia, ni Abigail (paràgrafs 223 i 231), ni Elmer (paràgraf 58-60) van trobar cap dificultat a seguir i entendre els subtítols. Tots diuen que veurien programació en forro subtitulada després d'aquesta experiència i que els agradaria que s'emetera en aquest format a la televisió. Miguel i Abigail, a més, pensen que seria útil, perquè estrangers i persones de São Tomé que no saben forro, l'aprengueren (paràgrafs 229 i 237).

Relació entre la situació dels ancians, el forro i les tradicions del país i possibles accions

Després de veure el vídeo, se'ls pregunta si pensen que hi ha una relació entre la situació de les persones ancianes, el forro i la pèrdua de les tradicions del país. Tots troben que existeix aquesta relació (paràgrafs 324-326), també Elmer (paràgraf 82). Quan se'ls pregunta sobre què es pot fer per pal-liar la situació, Flávia, Miguel i Abigail assenyalen com a clau per resoldre el problema un canvi en l'actitud dels joves que passe per una aproximació als ancians, ja que els aportaria un major coneixement cultural del país i de la vida en general (paràgrafs 332-336). Elmer hi coincideix (paràgraf 88 ). 


\subsubsection{Entre 20 i 30 anys}

Aquest grup el conformen António (cuiner), Amanda (perruquera), Mafalda (treballadora domèstica), Wilson (estudiant i paleta) i Evaristo (fotògraf, guia turístic i barber). Tant António com Mafalda i Amanda es refereixen al forro com la seua llengua materna; la d'Evaristo i Wilson és el portuguès. Evaristo, a més, és natural del Gabó i ha aprés forro després de huit anys a São Tomé.

Apreciació de la llengua

Abans de veure el vídeo, Wilson (paràgraf 43) i Amanda (paràgraf 130) troben que la millor llengua per fer gestions és el portuguès. António creu que el forro (paràgraf 138). Mafalda diu que haurien de gastar més el forro, però que la realitat és que només es parla amb persones ancianes (paràgrafs 155-157); per als joves és una llengua estranya i només parlen portuguès. Segons António, els vells eviten utilitzar el forro i ensenyar els seus coneixements perquè els joves no volen aprendre (paràgraf 329).

Després de veure el vídeo, se'ls pregunta si els agradaria que el forro tinguera més presència als mitjans de comunicació i que s'estudiara a l'escola o la universitat i tots responen que sí. António diu que tindria sentit, ja que s'estudien llengües estrangeres i no el forro (paràgraf 289). Per a Wilson (paràgrafs 88-95), si no s'inclou a les escoles, la llengua acabarà desapareixent. Mafalda també voldria que el seu fill poguera aprendre forro a l'escola i comenta que hi ha un programa de televisió que li agrada molt, precisament, per ser en forro (paràgrafs 291 i 293). Evaristo puntualitza que l'ensenyament de forro a les escoles hauria de ser entretingut (paràgraf 228). 
Quant als motius pels quals no es parla forro amb els fills, António diu que sí que el parlen, però per a fer bromes, per exemple; no amb la freqüència que ho fan els majors (paràgraf 305). Mafalda coincideix i diu que segurament si els parles forro l'entenen, però que no el saben parlar (paràgraf 309). Amanda diu que algunes persones sí que el parlen amb els fills, però que li agradaria que es fera més (paràgraf 317). Tot i aquestes afirmacions, tots ells parlen als seus fills en portuguès. Wilson ho justifica dient que la seua filla encara és molt menuda per parlar-li en una altra llengua que no siga el portuguès (paràgraf 29), ja que troba que aquesta li resultarà més fàcil d'aprendre per ser la que més se sent en el dia a dia (paràgraf 99). Evaristo creu que no es parla forro perquè la gent només pensa a expandir-se, a buscar oportunitats en altres països i en tot el que vinga de l'estranger (paràgraf 164). Creu que si es facilitara l'aprenentatge, més joves l'aprendrien perquè, diu, alguns estan disposats a aprendre de tot (paràgraf 168).

\section{Apreciació dels ancians}

Abans de veure el vídeo, se'ls pregunta com creuen que és la vida d'una persona anciana al país. Amanda confessa que mai s'havia plantejat com és la vida de les persones ancianes al país (paràgraf 163) tot i que després de veure el vídeo expressarà certa sensibilitat al respecte (paràgraf 205); Wilson creu que tenen carències i que algunes ho passen molt malament, però que depén de com siga la seua família (paràgraf 49); António i Mafalda coincideixen que aquells més discriminats $\mathrm{i}$ acusats de fetillers són els més empobrits (paràgrafs 168 i 169). Mafalda explica que de vegades els pares amaguen els nadons quan passen prop d'una persona anciana perquè no els vegen (paràgraf 168).

Després de veure el vídeo, Evaristo es mostra molt molest perquè considera que no tots els joves els 
maltracten i que l'origen d'algunes actituds actuals contra les persones majors es troba en com s'han comportat els ancians d'ara quan han sigut joves $\mathrm{i}$ en com han educat els seus fills (paràgraf 144). Cal tindre en compte que Evaristo va viure amb la seua àvia des que va arribar a São Tomé i Príncipe i que ella el va criar fins que va morir.

António troba que els joves ja no respecten els vells com es feia antigament i que amb aquesta actitud perden tots, ja que, diu, quan mor un vell, mor també una biblioteca (paràgraf 197). Mafalda explica que sa mare li conta que, antigament, quan es veia una persona anciana que carregava pes se l'ajudava i se l'acompanyava fins a casa i, si vivia sola, el veïnat anava a fer-li el treball de casa i, de vegades, l'ancià o l'anciana els donava menjar com a agraïment i menjaven junts. Actualment, en canvi, cap mare vol que el seu fill s'ajunte amb vells ni que mengen res que els puguen oferir per por que siguen fetillers i s'educa els xiquets perquè tinguen aquesta precaució. Mafalda creu que aquestes idees haurien d'esborrar-se de l'imaginari col·lectiu perquè els joves de hui seran els vells de demà i han de deixar-se ensenyar aspectes de la seua cultura, la seua llengua, les seues cançons i les danses antigues (paràgraf 199).

\section{Apreciació de la cultura del país}

Amanda coincideix amb l'opinió dels ancians que parlen al vídeo i troba que les seues tradicions cada vegada es veuen menys i que ara les persones de São Tomé s'interessen més pel que ve de fora (paràgraf 205).

Tant ella (paràgraf 277) com António (paràgraf 251) coneixen les cançons que es canten al vídeo; Wilson (paràgraf 87) i Mafalda (paràgraf 255) només una, però pensen que 
els seus fills no les coneixerien. Amanda també ho dubta, però no n'està segura (paràgrafs 281-283).

Pel que fa als elements culturals dels quals parlen els ancians, tots diuen conéixer-los excepte Evaristo, que desconeix què són els chocalhos i la ladenha (paràgrafs 103-127), i només ha vist el txiloli per televisió (paràgraf 133). Assenyala, però, que sí que ha celebrat molt el Bokadu quan vivia la seua àvia (paràgraf 137).

Apreciació de la subtitulació

A tots els agrada l'experiència d'haver vist material audiovisual en forro i subtitulat en portuguès i estarien disposats a veure programació subtitulada. António pensa que seria molt important que s'emetera en aquest format per a facilitar l'aprenentatge de forro a joves o persones més majors que no l'aprendrien d'altra manera (paràgraf 211). Mafalda creu que a través dels subtítols podria aprendre més coses sobre la seua cultura (paràgraf 221).

Relació entre la situació dels ancians, el forro i les tradicions del país i possibles accions

Després de veure el vídeo, tots pensen que hi ha una relació entre aquests tres factors, encara que Wilson assenyala que també hi ha alguns joves que s'interessen per les representacions culturals més tradicionals del país, com el txiloli (paràgraf 105). Evaristo reconeix que, encara que li encantaria revertir la situació, no sap com es podria fer (paràgraf 220). Mafalda, Amanda i António pensen que la clau està en un canvi de comportament dels més joves amb els més vells (paràgrafs 331,337 
i 329) en la mateixa línia que proposen els participants menors de 20 anys, és a dir, que els joves s'acosten als ancians (v. 7.2.1).

\subsubsection{Entre 30 i 40 anys}

Els participants entre 30 i 40 anys són Alda (treballadora domèstica i la persona que va servir com a ajuda per a establir les convencions dels subtítols, v. 6.5) i Matilde (administrativa a l'hospital). Cal tindre en compte que Alda és una amistat personal $\mathrm{i}$, per aquest motiu, els seus testimonis no comprenen només les opinions enregistrades sinó molts altres comentaris fora de càmera que es van recollir mitjançant les notes de camp (v. 6.3.3).

\section{Apreciació de la llengua}

Abans de veure el vídeo, per a ambdues, la millor llengua per a expressar-se és el portuguès i pensen que s'utilitza el forro entre persones que el saben parlar o, com opina Alda, també amb persones ancianes (paràgraf 105).

Matilde reconeix que els seus avis parlaven més forro del que es parla ara i que la seua filla de cinc anys, per exemple, no en sap (paràgraf 62). Quan se li pregunta per què, diu que no li ha parlat mai en forro perquè a ella mateixa ja la van educar en portuguès (paràgraf 86 ). Alda també parla en portuguès amb els seus fills perquè considera que és la llengua més correcta per dirigir-se a xiquets, encara que té pensat parlar-los forro quan tinguen l'edat adequada (paràgraf 209).

Com que ho identifica com un aspecte cultural del país, a Matilde li agradaria que s'estudiara a l'escola perquè, diu, s'aprendria millor a l'escola que a casa (paràgraf 80 ). Troba que la llengua està desapareixent. A Alda també li agradaria 
que el forro estiguera inclòs al sistema educatiu, perquè així els joves podrien aprendre la llengua (paràgraf 197).

Tant a Matilde (paràgraf 82) com a Alda (paràgrafs 201-205) els agradaria que hi haguera més programació en forro als mitjans de comunicació. Segons Alda, perquè forma part de la seua cultura i han de valorar el que és d'ells.

Alda comenta que abans es parlava més forro, però que ara les persones tenen recel de parlar-lo perquè és la llengua que parlen els vells $i$ als joves no els interessa (paràgraf 217).

\section{Apreciació dels ancians}

Abans de veure el vídeo, les dues pensen que la vida de les persones ancianes és complicada i a alguns se'ls acusa de fetilleria, sobretot quan no tenen recursos, com apunta Matilde (paràgraf 40).

Matilde pensa que els ancians ja han aportat el que devien al país i que és hora de prestar-los una especial atenció, ja que els joves d'ara també envelliran amb les mateixes dificultats (paràgraf 98). Dies després d'haver realitzat aquesta entrevista, comenta que ha estat pensant que els casos de discriminació a persones ancianes sempre estan associats al seu nivell econòmic i també al gènere. Segons explica, són més els homes considerats curanderos (terme amb una connotació positiva al país) que les dones, que són més habitualment acusades de fetilleres (connotació negativa).

Alda troba diferències en el tractament als ancians segons l'origen ètnic de les persones, però no especifica de quina manera (paràgraf 113). Assenyala que no totes les persones 
els maltracten, però sí que hi ha casos en els quals la mateixa família els abandona i acusa de fetilleria, o els deixa en asils i no se'n torna a preocupar. En acabar l'entrevista explica que, per aquest motiu, alguns ancians decideixen anar-se'n de casa i demanar refugi en algun centre social. Durant una altra conversa, Alda dona l'exemple d'un familiar proper que va deixar el pare ja vell en un centre social i mai no va tornar a visitar-lo. Açò la porta a reflexionar sobre com es comportaran els seus fills amb ella quan es faça gran, ja que dona per fet que també la deixaran de costat.

\section{Apreciació de la cultura del país}

Tant Matilde (paràgrafs 44-52) com Alda (paràgrafs 121-137) coneixen tots els trets culturals pels quals se'ls pregunta i pensen que els seus fills també els coneixerien. Pel que fa a les cançons que es canten al vídeo, només en coneixen una, però pensen que els seus fills no la coneixerien. Durant la fase de subtitulació del vídeo, de fet, Alda s'emociona molt quan identifica aquesta cançó perquè feia molts anys que no la sentia. Explica que la cantaven les dones quan anaven a llavar al riu i corregeix la versió que canta Graça al vídeo que, segons Alda, no és la correcta (paràgraf 185).

\section{Apreciació de la subtitulació}

A Matilde li agrada veure el vídeo subtitulat, perquè pensa que facilita la comprensió a persones que no entenen forro (paràgraf 72). Alda diu que de vegades han retransmés per la televisió alguna representació del txiloli amb subtítols i, en general, no li agrada perquè no li dona temps de llegir-los i preferiria que estigueren més temps en pantalla (paràgrafs 149-157). En el cas del vídeo que se li mostra per a aquesta investigació, diu que sí que ha tingut temps suficient. Tot i això, li agradaria que hi haguera més 
programació en forro subtitulada, perquè així aprendria més (paràgraf 169). Aprecia la idea que, a través d'un vídeo subtitulat, es puga conéixer en altres països quina és la situació de São Tomé i Príncipe, els seus ancians i les seues tradicions (paràgraf 173).

Passats uns dies, Alda diu haver estat pensant que seria interessant que retransmeteren algun programa infantil en forro amb subtítols perquè els xiquets començaren a aprendre i familiaritzar-se amb la llengua.

Relació entre la situació dels ancians, el forro i les tradicions del país i possibles accions

Després de veure el vídeo, ambdues pensen que hi ha una relació entre aquestes tres situacions. Matilde afegeix que les persones ancianes solen trobar-se més a gust quan es parla forro i que encara n'hi ha molts que responen en forro quan se'ls parla en portuguès. Pensa que seria una alegria per a ells que se'ls parlara en la seua llengua (paràgraf 94). Pensa que la solució passa per incloure el forro a l'escola i que, paral-lelament, les famílies eduquen els xiquets en el respecte als vells (paràgraf 100). Alda, en canvi, creu que són els dirigents del país els que haurien de prendre mesures i crear una organització que cuidara específicament els ancians i la preservació del forro (paràgraf 230).

\subsubsection{Entre 40 i 50 anys}

Dins aquest grup es troben Deolinda, de Cap Verd, qui fa 33 anys que viu a São Tomé i treballa de comptable; Alice, empresària nascuda a Portugal i criada a Suïssa, que fa 25 anys que viu a São Tomé i Príncipe; Élio, paleta i pedrer nascut a São Tomé i fill de pares capverdians; i Amélia, directora d'una ONG, nascuda i criada a São Tomé. 
Cal tindre en compte que a les preguntes sobre subtitulació no s'inclou a Deolinda ni a Alice, perquè al moment d'explicar-los en què consisteix aquesta investigació, van declarar estar molt habituades a veure pel-lícules subtitulades. Com que l'objectiu d'aquestes preguntes era esbrinar la percepció que tenen de la subtitulació les persones que no estan acostumades al contingut audiovisual en aquest format, ja que aquest és el context habitual a São Tomé i Príncipe (v. 5.2.3), i el cas de Deolinda i Alice no és l'habitual, es va decidir prescindir de les preguntes relacionades amb la subtitulació en les seues entrevistes.

Apreciació de la llengua

Abans de veure el vídeo, Alice identifica el forro amb la llengua que es parla al mercat o a les comunitats on es ven peix (paràgraf 102). Pensa que, antigament, la llengua unia les persones, ja que estava prohibida i parlar forro era el poder que tenien perquè el colonitzador no les poguera entendre, però que ara allunya els joves, que només volen aprendre anglès. En conseqüència, es produeix aquest allunyament entre els joves i els vells $\mathrm{i}$ el forro tendeix a desaparèixer (paràgraf 158).

Alice diu que li agradaria aprendre forro i que ho ha intentat moltes vegades, però que sempre té altres prioritats (paràgraf 162). Deolinda pensa que és difícil aprendre'l perquè els mateixos parlants no l'utilitzen més que per als proverbis o quan volen que algun estranger no els entenga (paràgraf 113). Conta que, quan va arribar al país, algunes persones li explicaven que no parlaven forro a casa perquè estava prohibit i necessitaven saber portuguès per anar a l'escola (paràgraf 169). Observa un interès en alguns joves per recuperar la llengua, però li sembla que de vegades es fa teatre utilitzant la llengua a la televisió, ja que, per a ella, qui 
vertaderament vol recuperar la llengua la parla al carrer amb qui siga i quan siga (paràgraf 181).

Élio pensa que la millor llengua per a fer gestions és el portuguès i considera que es parla forro o unes altres llengües criolles quan s'està amb persones que també parlen aquestes llengües (paràgrafs 49-61 i 77). Amélia opina que són vàlids tant el portuguès com el forro, però que seria important que els especialistes de la salut pogueren entendre forro, ja que a la seua feina hi ha persones que no parlen bé portuguès o se senten clarament més còmodes expressant-se en forro (paràgraf 65). Diu que no són molts casos, però que encara n'hi ha. A banda dels moments quan tracta amb gent que té dificultats amb el portuguès dins del seu àmbit professional, Amélia parla forro per cantar o fer bromes amb els amics (paràgraf 69).

Tant a Élio (paràgrafs 163-171) com a Amélia els agradaria que a les escoles s'estudiara forro. Amélia diu que ho va proposar a l'escola dels seus fills, però la persona amb la qual va parlar li va dir que ja es va intentar i que el projecte va fracassar (paràgrafs 148-152). Amélia pensa que potser no es va presentar de la forma adequada i que funcionaria si es fera de forma divertida, a través de jocs, per exemple, en lloc de tractar-ho com una assignatura a l'ús.

Élio diu no saber per què els pares que saben forro ja no el transmeten als fills perquè els capverdians sí que transmeten la seua llengua (paràgraf 183), observació en la qual coincideix amb Deolinda (paràgraf 201). Per a Amélia, el motiu principal pel qual les famílies que parlen forro ja no el transmeten als fills és que la llengua no es troba present al currículum escolar i encara queda alguna cosa de l'antic prejudici que considerava el portuguès com la llengua culta i el forro estava prohibit o mal vist. 
Tot i això, assenyala que també hi ha persones que es preocupen per mantindre la llengua i que els seus fills l'aprenguen. Creu que aquestes persones segur que s'adheririen a un programa escolar en forro si en tingueren l'oportunitat (paràgraf 160).

Els agradaria que hi haguera més programació en forro però, per a Amélia, ha de tindre un sentit. Posa l'exemple d'un programa que s'emet sobre societat a la TVS en to còmic com el tipus de programes que li agradaria veure en forro (paràgraf 156).

\section{Apreciació dels ancians}

Abans de veure el vídeo, Alice explica que la vida dels ancians és molt precària $i$ sofrida (paràgraf 106). Élio coincideix que a São Tomé no es tracta molt bé els ancians i se'ls acusa de fetilleria, encara que observa que actualment aquestes concepcions estan canviant gràcies al treball d'algunes ONG i d'algunes iniciatives governamentals, tot i que els ancians encara eviten el contacte amb els més joves o fins i tot no ixen de casa per por a l'insult (paràgraf 89). Deolinda comenta que la pensió mensual que reben és tan baixa que de vegades no els arriba ni per a una setmana (paràgraf 117). Amélia assenyala el problema de l'accés als aliments, ja que el seu estat físic ja no els permet buscar menjar a la natura com poden fer-ho els més joves. Indica que al país sí que es té molt de respecte pels ancians com a norma general, però també cita els casos d'acusació de fetilleria. Diu que açò ocorre perquè, donat el procés normal d'envelliment, les persones majors de vegades deixen de tindre el discerniment que tenien quan eren més joves, pateixen d'insomni i deambulen per la casa o per fora, i tot açò es veu com a signes de fetilleria. Amélia també pensa que l'abandonament dels ancians es deu al fet que les famílies ja no tenen temps de cuidar els seus avis i s'ha perdut la tendència que hi 
havia antigament segons la qual els avis cuidaven els nets i implicava que els xiquets veieren natural que els pares cuidaren els vells i, per tant, ells feien el mateix quan creixien (paràgraf 77 ).

Apreciació de la cultura del país

Quant a les preguntes sobre elements culturals que se'ls fa abans que comence el vídeo, Élio (paràgrafs 97-113) i Amélia (paràgrafs 81-97) els coneixen tots, mentre que Alice no sap què són els chocalhos ni la ladenha. Deolinda sols desconeix la ladenha (paràgrafs 108-130). Cal recordar que Deolinda és de Cap Verd i Alice és nascuda a Portugal i criada a Suïssa. Viuen a São Tomé des de fa 33 i 25 anys respectivament. Élio (paràgrafs 150-155) i Amélia coneixen una de les cançons que s'hi canten, però Amélia diu que els seus fills no les coneixerien (paràgrafs 140-144) i Élio que gent de 20 o 25 anys tampoc les haurien sentides mai (paràgraf 159). Alice no en coneix (paràgraf 166).

Alice pensa que São Tomé no té capacitat per conservar la seua cultura perquè la gent té altres prioritats (paràgraf 170). Amélia diu que li agradaria tindre uns coneixements més profunds sobre la cultura de São Tomé, perquè té molts detalls i per a entendre-la completament, quasi és necessari estudiar (paràgraf 101). Deolinda pensa que, en el cas del Bokadu, el motiu que no se celebre tant seria que als joves els semble antihigiènic que tota la família menge de la mateixa cullera. Així i tot, diu que al seu treball els seus companys van demanar que els donaren eixe dia lliure per poder celebrar-ho amb la família (paràgraf 197). En comparació, observa que a Cap Verd hi ha una major preocupació de la població per conservar les tradicions. 
Apreciació de la subtitulació

Després de veure el vídeo, tant Élio (paràgrafs 142-146) com Amélia se senten còmodes amb la subtitulació i veurien més programació subtitulada (paràgraf 156). Amélia explica que per Nadal ja es va emetre una campanya governamental que consistia en un vídeo subtitulat, i pensa que té molt de sentit utilitzar aquesta tècnica perquè és una forma de no excloure ningú (paràgraf 128).

Relació entre la situació dels ancians, el forro i les tradicions del país i possibles accions

Després del vídeo, Alice, Élio i Amélia pensen que sí que hi ha una relació. Alice opina que s'aparta els ancians quan encara podrien aportar coses a la societat; per exemple, donar algunes hores de classe (paràgraf 174). Élio pensa que si s'utilitzaren més els criolls, les persones serien més sensibles i afectuoses les unes amb les altres, perquè era el que passava abans (paràgraf 199). Amélia assenyala com un problema afegit el fet que a São Tomé no es parle de sentiments ni afectes i que siga quasi un tabú. Pensa que açò fomenta que hi haja famílies desestructurades i que no es creen vincles afectius amb els avis de la família. Pensa que açò no ocorria antigament perquè els avis eren els encarregats de contar històries i transmetien així la cultura popular; ara açò no ocorre perquè els avis ja no compleixen aquesta funció. Troba que és important incentivar aquesta relació entre avis i nets, però creu que és difícil d'implementar en famílies desestructurades (paràgraf 165). Deolinda creu que el problema és que a São Tomé i Príncipe se li dona més valor a tot el que ve de fora (paràgraf 205). 
Encara que no entra en detalls, Alice diu que sí que es podrien prendre mesures per pal-liar la situació de degradació del forro, les tradicions del país i dels ancians, però que hauria de planificar-se molt bé perquè ara els joves només pensen en el futur i en les noves tecnologies (paràgraf 178). Élio pensa que el canvi ha de donar-se en primer lloc al si familiar, en segon lloc a l'escola i després a la societat (paràgraf 203). Amélia creu que es poden fer moltes coses i explica un dels projectes que pretén desenvolupar l'organització que presideix i que consisteix a crear horts de plantes medicinals als seus centres. Aquests horts s'obriran al turisme i seran les persones ancianes del centre els que actuaran com a guies explicant per a què serveix cada planta i preparant infusions als visitants. Pensa que mitjançant aquest projecte sentiran que els seus sabers estan valorats i pot ser-hi molt positiu (paràgraf 169).

Deolinda pensa que és difícil posar una solució, però pel que fa a la part cultural, creu que aquells que coneixen certes representacions són els que s'han d'encarregar de divulgar-les i que no s'obliden (paràgraf 209).

Durant algunes converses posteriors i fora de càmera, dues de les persones d'aquest grup expressen reflexions que han fet a partir de les entrevistes. En l'àmbit lingüístic, Alice pensa que, després de tants anys al país, el motiu pel qual no considera que en coneix bé la cultura és que mai ha arribat a aprendre forro. Amélia reflexiona sobre el coneixement cultural que té del seu propi país i el que tenen els seus fills. Explica que mai havia pensat en això, però que, en veure el vídeo s'havia adonat que ella mateixa hauria d'aprofundir més en molts aspectes culturals i, sobretot, iniciar els seus propis fills, que tenen un gran desconeixement. 
En resum, a tots els participants de tots els grups d'edat els agradaria que s'ensenyara forro a les escoles i que hi haguera més programació a la televisió en aquesta llengua. També tenen una percepció positiva de la subtitulació. Entre els aspectes positius que li troben, estan la utilitat que pensen que tindria per facilitar l'aprenentatge de forro, que seria una forma d'acostar la llengua als xiquets i els joves, que ajudaria a aprendre coses sobre la cultura del país i que seria una forma de no excloure ningú. Així mateix, tots troben una relació entre la situació decadent dels ancians i la del forro i moltes tradicions del país. Respecte a aquest últim aspecte, s'observa que, efectivament, com més joves són els entrevistats menys tradicions coneixen.

Cal assenyalar l'estímul que suposa el vídeo de les persones ancianes en certes persones: Amanda, que un primer moment mostra cert desconeixement 0 indiferència envers la situació de les persones ancianes, sembla empatitzar més després del visionat; Elmer diu no saber res del forro i tampoc expressa cap interès abans de veure el vídeo, però després es mostra a favor que tinga més presència al sistema educatiu i als mitjans de comunicació perquè creu que això facilitaria l'aprenentatge d'aquesta llengua; Evaristo, tot i mostrar una actitud hostil al començament per l'etiqueta que se sol posar als joves de maltractar els vells, es mostra d'acord amb el que expressen les persones ancianes del vídeo quan acaba de veure'l; per últim, Amélia, Alda, Matilde i Alice, reflexionen temps després de veure el vídeo sobre alguns dels aspectes dels quals s'hi parla.

És clar que només amb aquestes contribucions no és possible validar la proposta d'aquesta tesi, ja que les opinions dels participants són subjectives i insuficients. Per 
aquest motiu i donat el caràcter etnogràfic d'aquesta investigació, s'utilitza la triangulació de dades com a mètode d'anàlisi dels resultats (v. 3.2.3).

\subsection{RESULTATS DELS GRUPS DE DISCUSSIÓ I ENTREVISTES AMB EXPERTS}

Els resultats dels grup de discussió i entrevistes amb els experts consultats es presenten per separat segons els grups d'experts (v. 6.2.2). En acabar el debat $i$ les entrevistes, tots i totes van puntuar de manera anònima de l'1 al 10 una sèrie d'afirmacions sobre la utilitat de la TAV en projectes de cooperació en general i en el cas concret de São Tomé i Príncipe, essent 1 el valor més baix (inútil) i 10 el més alt (valor essencial). La transcripció d'aquestes sessions està disponible a l'annex IV. Aquest annex conté els documents Josu (cooperació lingüística), Patxi (cooperació lingüística), Experts $\mathrm{Cl}$ i Experts TAV.

\subsubsection{Experts en $\mathrm{Cl}$}

Aquest primer grup de discussió, amb agents del camp de la $\mathrm{Cl}$, aporta una sèrie d'opinions i concepcions sobre la revitalització lingüística i la TAV en projectes de $\mathrm{Cl}$. Aquestes contribucions es presenten dividides segons les categories temàtiques que se n'extrauen (6.4):

1. La cooperació amb un punt de vista occidental.

2. La relació de poder entre les llengües.

3. L'efecte de no tindre en compte la llengua. 
4. Les creences $\mathrm{i}$ les representacions sobre les llengües.

5. La utilitat de la cooperació lingüística.

6. Els problemes de la cooperació lingüística.

7. La consideració de la revitalització lingüística no com a cooperació sinó com a política.

8. La cooperació lingüística a São Tomé i Príncipe.

9. La relació entre la situació del forro i la dels ancians.

10. La utilitat de la subtitulació.

11. Els problemes de la subtitulació.

Cooperació amb punt de vista occidental

Begoña i Celia entren en un xicotet debat sobre la cooperació amb un punt de vista occidental: per una banda, Begoña reconeix que la cooperació sol fer-se amb la visió cultural dels països del Nord i que d'alguna forma s'imposa als territoris on es realitzen els projectes, encara que la idea occidental de desenvolupament no sempre coincideix amb la idea de desenvolupament dels països on s'hi treballa. A més, explica que aquests països tenen assumit que les entitats estrangeres organitzen aspectes com la seguretat del país, la salut, l'educació, etc. que, en principi, correspondrien al Govern. Celia planteja el cas de São Tomé on, segons considera, algunes organitzacions internacionals com Nacions Unides o Unicef estan per damunt de les decisions del mateix Govern del país i, per tant, són aquestes entitats les que promouen $\mathrm{i}$ organitzen certs estudis o projectes. 
Begoña troba que açò és completament normal en cooperació. Celia replica que això és una forma antiga de fer cooperació, en què es treballa en allò que certes entitats volen fer i no en allò que el país necessita, i troba que aquesta forma de treballar no és respectuosa (paràgrafs 610-626).

\section{La relació de poder entre les llengües}

La segona categoria temàtica que sorgeix en aquest grup de discussió, és la relació de poder entre les llengües. César comença per esmentar els casos d'algunes comunitats que deixen de parlar la seua llengua perquè està mal vista. Pensa que quan es fa un projecte de cooperació cal tindre en compte que, si els cooperants es comuniquen amb les comunitats natives en un altre idioma majoritari, aquestes poden sentir-se agredides per la imposició lingüística (paràgraf 107).

Celia posa l'exemple d'un cas recent a São Tomé i Príncipe: una fundació nacional que rep finançament d'Holanda, va organitzar una biennal al país en la qual participaven artistes internacionals. Les bases de participació d'aquesta biennal estableixen que tots els artistes han de presentar la seua proposta en anglès, requisit que discrimina de forma evident aquells artistes locals sense formació en aquesta llengua (paràgraf 190). Esther, Ruth, Begoña i Mario expressen certa indignació pel fet que els artistes de São Tomé i Príncipe no puguen presentar els seus treballs en portuguès (paràgrafs 192-217).

Per a Esther, açò és un exemple d'imposició d'una llengua sobre una altra (paràgraf 192) i explica que, a Uganda, tothom parla en anglès i s'han abandonat l'ugandès i altres llengües i dialectes que s'hi parlaven. Troba que açò també comporta una pèrdua cultural (paràgraf 200). 


\section{Efectes de no tindre en compte la llengua}

El debat sobre aquesta qüestió, dona pas als efectes de no tindre en compte la llengua als treballs de cooperació, ja que, per a Esther, quan s'introdueix una llengua diferent en una cultura, es perd el sentit de la cultura originària (paràgraf 134). Ruth pensa que no es perd, però que sí que pot sentir-se agredida (paràgraf 136). Tot i això, aquesta experta dubta si per a fer cooperació en un país cal formar-se en les llengües que s'hi parlen, perquè pensa que pot ser difícil; en canvi, reconeix que quan vas a un altre país a fer un projecte que potser és aliè per als natius i no es respecta la seua llengua, segurament els resultats d'aquest projecte no seran satisfactoris (paràgraf 140).

César comenta que quan no es deixa espai a un col-lectiu per a desenvolupar la seua identitat, entenen tot el que ve de fora com una agressió i, per tant, és important que cada comunitat puga expressar-se en la seua llengua i que, sempre que siga possible, tot el que els arribe siga també en la llengua que parlen (paràgraf 180). Es repeteixen els efectes de no tindre en compte la llengua en l'anècdota que explica Celia sobre la biennal artística que es va realitzar a São Tomé, en la qual aquells artistes que no sabien anglès van quedar exclosos d'aquest esdeveniment (paràgrafs 190-257).

\section{Creences i representacions sobre les llengües}

En aquests experts, s'identifiquen algunes creences i representacions sobre llengües. Per una banda, tots coincideixen que una llengua és un bé cultural d'una societat $i$ una forma de veure el món (paràgrafs 203 i 508), que mereix protecció per evitar la seua desaparició (paràgraf 184). Begoña explica que en alguns països parlar o no certa llengua determina el nivell d'estudis 
de les persones (paràgraf 205) i Esther coincideix que açò provoca una discriminació (paràgraf 207).

Per una altra banda, César observa que, de vegades, les llengües es mantenen per interessos polítics. També troba que la revitalització lingüística pot desintegrar una nació en donar als parlants d'aquestes llengües un cert estatus i açò resulta problemàtic per als governs; per això no solen estar interessats en projectes de revitalització lingüística. Insisteix que les llengües no són neutres i poden convertir-se en armes llancívoles (paràgrafs 184 i 510)

Esther pensa en el cas específic de les persones ancianes de São Tomé, reflexiona sobre la relació que pot tindre la situació que viuen amb la situació del forro i planteja que si es treballa en favor del forro, també es millorarà la situació social d'aquestes persones (paràgrafs 301 i 305). També observa que en la transmissió d'una llengua es difon una forma d'expressar-se, de viure i de sentir (paràgraf 714). En relació amb aquesta opinió d'Esther, Begoña pensa que per a una persona a qui no han educat en forro, aquesta llengua no significa res (paràgraf 712) i César, que el més important a l'hora de pensar en projectes són les persones, no les llengües (paràgraf 732).

\section{Utilitat de la cooperació lingüística}

Quan es proposa el debat sobre la utilitat de la cooperació lingüística, després de llegir les frases de Garabide Kultur Elkartea (2015-2016), César assenyala que la llengua és una qüestió important, ja que moltes persones perden l'autoestima perquè la llengua que parlen no és socialment valuosa o reconeguda i guarden silenci perquè no poden expressar-se. En aquests casos, 
la recuperació de la llengua suposa la recuperació del rol d'aquestes persones (paràgraf 307).

Celia troba que evitar que una llengua es perda paga la pena senzillament per formar part de la cultura de la comunitat que la parla i Mario s'hi mostra d'acord (paràgrafs 160164). César opina que una llengua que es perd és un empobriment de la humanitat i cal lluitar per evitar-ho (paràgraf 184).

Per a Mario, en canvi, la cooperació lingüística no és un tipus de cooperació prioritari perquè, abans de treballar per promoure la cultura d'un país, haurien d'estar resolts altres aspectes en relació amb les infraestructures, la pobresa, etc. (paràgrafs 166-174) César hi està d'acord (paràgrafs 184-188).

\section{Problemes de la cooperació lingüística}

A partir d'aquestes últimes observacions, aquests experts també identifiquen certs problemes de la cooperació lingüística. Per una banda, César assenyala que les llengües també són focus d'identitats i que algunes identitats són assassines (paràgraf 107). Per una altra banda, considera que, de vegades, cal fer un esforç econòmic tan gran per mantindre una llengua que aquesta llengua es conserva per interessos polítics i no per un interès social, ja que, si els recursos són escassos, potser el país els necessita per a una altra cosa (paràgraf 184).

Celia troba que un problema de la cooperació lingüística seria el mateix país on es desenvolupa, ja que, segons ella, almenys en el cas de São Tomé i Príncipe no hi ha interès per projectes culturals, perquè el que volen són projectes que suposen infraestructures, subministrament de medicaments 0 
formacions a Europa i, pel que fa a la cultura, al mateix Govern li interessa més tot el que ve de fora (paràgraf 474).

Begoña pensa que la cooperació lingüística pot ser conflictiva en països amb moltes llengües i dialectes, ja que s'hauria de triar la revitalització d'una llengua en lloc d'unes altres i això marcaria una diferència amb aquelles que es deixen de costat (paràgraf 497).

La revitalització lingüística no és cooperació sinó política

Abans de preguntar pel cas concret de São Tomé i Príncipe, tant César com Begoña consideren que la revitalització lingüística no és cooperació sinó política, i pertany al Govern de cada país com a política lingüística (paràgrafs 838 i 966).

\section{Cooperació lingüística a São Tomé i Príncipe}

Quan es plantegen les possibilitats de realitzar projectes de cooperació lingüística a São Tomé i Príncipe, Celia pensa que seria difícil per la falta d'interès que hi ha en projectes culturals (paràgraf 474). Així i tot, creu que sí que és possible realitzar-la, ja que sol treballar-se en una comunitat, un barri o una zona molt concreta (paràgraf 499). De fet, dona l'exemple d'uns voluntaris de la seua ONG que li havien explicat com les persones ancianes s'emocionaven quan els xiquets els deien alguna cosa en forro ${ }^{18}$.

Aquests voluntaris participaven en un projecte intergeneracional que l'ONG desenvolupa a la comunitat de Santo Amaro durant l'estiu per a estimular el contacte entre xiquets $\mathrm{i}$ ancians. Entre les activitats que es realitzen, es porta els xiquets i les xiquetes a visitar persones ancianes perquè els expliquen contes, o simplement per visitar-los. En aquesta 
Per a César, treballar per la revitalització del forro a São Tomé pot donar un estatus d'exclusivitat als ancians, que són qui coneixen la llengua, i dona exemples de com es podria fer: organitzar un festival, un concurs de poesia o una recopilació de refranys 0 contes $\mathrm{i}$ que els ancians els expliquen als xiquets, per exemple (paràgraf 542).

Ruth no veu viable que es facen llibres de poesia i contes perquè creu que el Govern no col-laboraria; pensa que és millor que les iniciatives sorgisquen de la mateixa comunitat. En general, tots coincideixen que la cooperació lingüística seria possible a São Tomé i Príncipe de manera transversal i amb l'objectiu de millorar la situació de les persones ancianes (paràgraf $556)$.

Relació entre la situació del forro i la de les persones ancianes

Sobre la relació entre la situació del forro i la dels ancians, a César li sorprén la possibilitat que indiquen els entrevistats no ancians de São Tomé (v. annex III) que si la marginació del forro està vinculada a la de les persones ancianes, quan es millore la situació de les persones ancianes, també ho farà la situació de la llengua (paràgraf 652). Cal recordar que Esther ja s'havia pronunciat sobre aquest punt (paràgrafs 301 i 305) i sí que intuïa que podia existir aquesta relació entre la llengua i les persones ancianes.

ocasió, també hi havia una persona de São Tomé que, voluntàriament, ensenyava als xiquets nocions de forro. En aquest context, durant les visites a les persones ancianes, els xiquets i les xiquetes els saludaven en forro $i$, segons el testimoni d'aquests voluntaris, els ancians s'emocionaven per aquest motiu. 


\section{Utilitat de la subtitulació}

Pel que fa a la utilitat de la subtitulació, César opina que, encara que la subtitulació li sembla una eina imprescindible en el cas específic del crioll forro i les persones ancianes de São Tomé (paràgraf 764), dubta que amb els subtítols es puga aprendre i dignificar una llengua (paràgraf 942). Pensa que la subtitulació pot aconseguir arribar a més persones i donar visibilitat a una llengua, però creu que aquesta segona funció pot ser problemàtica si es fa de forma interessada, encara que no dona cap exemple. Es mostra d'acord sempre que es faça amb la idea que les llengües dignifiquen i engrandeixen les persones, ja que aportaria autoestima a les comunitats que parlen les llengües que se subtitulen (paràgraf 1032).

Celia pensa que la subtitulació pot ser útil per a facilitar l'aprenentatge de forro, ja que al país també s'emet un programa per aprendre anglès. No creu que resultara molt problemàtic que la majoria de la població accedira a aquest programa hipotètic perquè, segons explica, moltes cases no tenen algunes necessitats bàsiques però sí que tenen televisió i, en cas que no siga així, moltes persones solen acostar-se a establiments que sí que en tenen per poder seguir aquest programa d'aprenentatge d'anglès i podrien fer-ho també per aprendre forro (paràgrafs $807-890$ ).

Sobre aquesta idea de Celia, Esther creu que podria funcionar un programa dirigit a xiquets i joves. També planteja la possibilitat que aquest programa es dirigira a la gent que ve de fora, per a posar-los en contacte amb el forro (paràgraf 900).

Begoña no veu sentit a aquestes propostes (paràgraf 926), encara que sí contempla la possibilitat d'utilitzar la 
subtitulació en altres àmbits com l'educació per a la salut, tot i que no n'entra en detalls. En qualsevol cas, explica que caldria buscar la població beneficiària de la subtitulació (paràgraf 1010). Mario observa que es podria anar comunitat per comunitat i desenvolupar d'aquesta manera el projecte que s'haja realitzat amb els subtítols (paràgraf 1012).

\section{Problemes de la subtitulació}

Dos dels experts també assenyalen els problemes de la subtitulació. Ruth diu que durant la seua estada a São Tomé va trobar moltes persones analfabetes i molts xiquets que no estaven escolaritzats. Per això sosté que la subtitulació no seria útil en aquest país, ja que la majoria de persones no podrien llegir els subtítols (paràgrafs 766 i 1020).

Segons César, la subtitulació suposaria també un problema econòmic per les despeses que causaria posarla en pràctica (paràgraf 962).

\section{Valoració anònima d'ítems}

Un cop finalitzat el debat, es va demanar a aquest grup d'experts la valoració anònima d'ítems, els resultats de la qual s'il-lustren a la taula següent. Cal tindre en compte que els resultats de la valoració d'ítems s'entenen com un resum numèric de la discussió desenvolupada. 
Taula 17. Valoració d'ítems dels experts en $\mathrm{Cl}$.

\section{VALORACIÓ D'ÍTEMS DELS EXPERTS EN CI}

\begin{tabular}{lc}
\hline \multicolumn{1}{c}{ ÍTEM } & \multicolumn{1}{c}{ PUNTUACIÓ } \\
\hline $\begin{array}{l}\text { La cooperació lingüística s'hauria de } \\
\text { tindre més en compte en treballs de Cl. }\end{array}$ & $8,6,5,10,9$ i 10 \\
$\begin{array}{l}\text { La cooperació lingüística seria útil en } \\
\text { algun dels països on han treballat. }\end{array}$ & $4,6,2,10,10$ i 8 \\
\hline $\begin{array}{l}\text { En quina mesura seria útil la cooperació } \\
\text { lingüística en el cas particular dels } \\
\text { ancians de São Tomé i Príncipe. }\end{array}$ & $7,8,5,10,10$ i 10 \\
$\begin{array}{l}\text { La utilitat de la subtitulació com a } \\
\text { ferramenta al camp de la cooperació. }\end{array}$ & $8,6,5,6,9$ i 10 \\
\hline
\end{tabular}

\subsubsection{Experts en TAV}

El segon grup de discussió contribueix a la visió dels professionals de la possibilitat d'incloure la TAV en projectes de $\mathrm{Cl}$. En aquest cas, els resultats d'aquest grup es presenten dividits en les següents categories (6.4):

1. El desconeixement de les possibilitats de la TAV com a eina per a la $\mathrm{Cl}$.

2. La relació entre la situació del forro i la dels ancians.

3. El paral-lelisme amb la situació sociolingüística pròpia.

4. La importància de la situació lingüística. 
5. Les idees d'ús de la TAV en $\mathrm{Cl}$.

6. La modalitat d'àudio en forro i subtítols en portuguès.

7. El doblatge com a forma de rehabilitació de llengües quan no hi ha alfabetització.

8. La utilitat de la subtitulació.

9. Els problemes de la subtitulació.

10. L’acceptació de la subtitulació.

11. Els temes de recerca futura.

Relació entre la situació del forro i la dels ancians

Una vegada informats de la situació del forro i de les persones ancianes a São Tomé, tots els experts pensen que hi ha una clara relació entre la situació del forro i la situació dels ancians (paràgrafs 150-152).

Paral-lelisme amb la situació sociolingüística pròpia

Tots identifiquen de seguida un paral-lelisme amb la situació sociolingüística pròpia, és a dir, es troben similituds entre la situació del forro i la del valencià. Marina posa l'exemple de son pare, que es va sentir discriminat a l'escola per no parlar castellà fins que es va adaptar (paràgraf 150). Explica que, encara que menys que abans, aquestes discriminacions encara es donen hui en dia. La resta s'hi mostra d'acord (paràgrafs 216-226). 
Importància de la situació lingüística

En un principi, Mar qüestiona la importància de la situació lingüística de São Tomé, ja que, encara que troba que la situació del forro és greu, li pareix prioritari treballar contra l'abandonament $\mathrm{i}$ el maltractament de persones majors (paràgraf 166).

Desconeixement de les possibilitats de la TAV com a eina per la $\mathrm{Cl}$ i doblatge com a forma de rehabilitació de llengües quan no hi ha alfabetització

Els experts en TAV reconeixen el seu desconeixement de les possibilitats d'aquest àmbit de la traducció com a eina per a la $\mathrm{Cl}$. Marina reconeix que mai s'havia plantejat que subtitulant vídeos podien aconseguir-se coses més enllà d'entendre el contingut d'un material audiovisual, i li agrada aquesta idea (paràgraf 363). Clara i Jordi s'hi mostren obertament d'acord (paràgrafs 365 i 367). Mar assenyala la possibilitat d'utilitzar el doblatge com a forma de rehabilitació de llengües quan no hi ha alfabetització (paràgraf 136).

Idees d'ús de la TAV en Cl

Encara que es tracta d'una aplicació de la TAV desconeguda per a tots, els experts donen algunes idees d'ús de la TAV en Cl. Jordi posa l'exemple del Festival de Cinema que es realitza al Sàhara i la traducció de comunicats, campanyes o pàgines web d'ONG (paràgraf 97). A Marina se li ocorre que podria servir perquè persones que parlen llengües minoritàries puguen tindre contingut en el seu idioma a la televisió (paràgraf 89). En aquesta línia, Mar assenyala la possibilitat d'alfabetitzar a través de la subtitulació (paràgraf 137) i Clara, la d'oferir material audiovisual en 
llengües minoritàries a la televisió i facilitar que es puga triar l'opció de veure aquest material doblat o subtitulat (paràgraf 138).

Per al cas concret que es planteja en aquesta tesi, tots pensen que la TAV podria tindre una incidència positiva: Clara i Mar pensen que el material doblat en forro el fet de subtitular aquesta llengua pot canviar la percepció que es té envers la llengua. A més, Clara assenyala que, per a xiquets i joves, la TAV pot ajudar al fet que aprenguen la llengua de forma divertida, a través d'una sèrie, per exemple (paràgraf 106, 439 i 441).

Mar especifica que el material $a m b$ àudio en forro tindria una major incidència encara que no es tractara de produccions pròpies del país i proposa doblar en aquesta llengua material que puga ser atractiu per al públic i subtitular-lo en portuguès (paràgraf 393).

Pel que fa a qui doblaria, Mar proposa que ho facen els ancians a través de tallers de doblatge en els quals puguen doblar dibuixos animats, per exemple (paràgrafs 413-419 $\mathrm{i}$ 439). Marina proposa una versió del programa d'À Punt Bambant per casa $^{19}$ - en què es visiten diferents comarques per donar a conéixer la cultura i el patrimoni de cadascuna- i que els presentadors visiten persones ancianes de diferents parts del país i que expliquen característiques culturals d'eixa zona com, per exemple, la gastronomia (paràgraf 441).

Clara i Jordi proposen un cinema itinerant (paràgrafs 487-493). Tots estan d'acord que el més positiu seria combinar contingut produït a São Tomé i Príncipe amb contingut 
estranger per tal que resultara més atractiu (paràgrafs 487-505). Jordi proposa projectar una pel-lícula comercial doblada en forro $i$ subtitulada en portuguès $i$, abans que comence, passar un curtmetratge o una campanya governamental sensibilitzant sobre la situació de les persones ancianes (paràgrafs 509 i 513). Mar afegeix que també podria fer-se un taller d'introducció a la llengua amb nocions bàsiques (paràgraf 517 ).

\section{Modalitat d'àudio en forro i subtítols en portuguès}

Encara que no se'ls havia especificat, en sentir el cas del forro tots els experts van pensar d'utilitzar la modalitat de l'àudio en portuguès i els subtítols en forro i, per tant, es plantegen la problemàtica que els espectadors no sàpiguen llegir en forro. Quan se'ls proposa l'opció contrària, és a dir, modalitat d'àudio en forro i subtítols en portuguès, tots consideren millor aquesta opció (paràgrafs 266-288).

\section{Utilitat de la subtitulació}

Mar, Jordi i Marina conversen sobre la utilitat de la subtitulació, més enllà dels beneficis que té quan es dirigeix a persones sordes. Consideren que milloraria el coneixement d'una llengua per veure com s'escriu, facilitaria que s'entenga el contingut del vídeo en llocs amb molt de soroll com bars o gimnasos, permetria veure la versió original de la pel-lícula o programa, etc. Mar també assenyala que la subtitulació pot ser útil en comunitats lingüístiques no alfabetitzades, ja que els exposa a la versió escrita de la seua llengua i és una forma entretinguda d'aprendre (paràgrafs 15-77).

En el cas específic de São Tomé, tant Clara com Mar troben que la subtitulació pot servir per a acostar un 
assumpte desconegut o llunyà (la situació dels ancians i del forro) a la població que, en veure'l integrat a la televisió, deixaria d'entendre'l com un fet aliè i es reduiria el rebuig contra la llengua i les persones ancianes (paràgrafs 343-345). A més, Marina pensa que els xiquets són necessaris per recuperar la llengua. I perquè açò succeïsca, la subtitulació pot ser una bona forma per aconseguir que l'entenguen (paràgrafs 427-431).

\section{Problemes de la subtitulació}

Tot i això, els experts també identifiquen possibles problemes de la subtitulació a São Tomé i Príncipe. Per a Clara, un dels problemes que sorgirien seria el debat entre el doblatge i la subtitulació de la mateixa manera que existeix a Espanya, per exemple. També la dificultat que tinga la població per llegir els subtítols i qui s'encarregaria de realitzar els subtítols (paràgrafs 375 i 383).

Jordi pensa que allò més difícil seria convèncer la gent perquè vegen programació en forro. Per això, troba que la subtitulació pot ser una eina útil al context de São Tomé i Príncipe, però més a llarg termini, quan s'haja avançat amb una tasca de recuperació de la llengua a les escoles (paràgrafs 385 i 421).

\section{Acceptació de la subtitulació}

Sobre l'acceptació de la subtitulació, Mar explica que, en general, les persones no tenen per què pensar com podria millorar la subtitulació la situació del forro i dels ancians, però, quan se'ls presenta aquesta proposta, la resposta és positiva perquè, segons creu, és una bona idea (paràgraf 324). Marina hi està d'acord i afegeix que, sovint, la gent no vol subtítols i els 
incomoden durant els primers cinc minuts d'una pel-lícula, però després s'hi acostumen i, en el cas de São Tomé i Príncipe, pensa que també ho farien (paràgraf 334).

Per a Marina, que ja havia proposat la realització d'un programa semblant a Bambant per casa, es podria analitzar la possibilitat de fer un programa en forro de jocs o cançons tradicionals dirigit a xiquets que presentarien persones ancianes; també proposa un altre en el qual es visiten ancians de cada poble $\mathrm{i}$ que expliquen les característiques culturals i gastronòmiques de cada zona (paràgrafs 435 i 441).

Per últim, Clara apunta la necessitat de fer un estudi específic per saber quines serien les convencions de subtitulació més adequades per a les persones de São Tomé i Príncipe (paràgraf 383).

\section{Valoració d'ítems}

A continuació s'inclou la taula amb la valoració d'items d'aquests experts sobre els temes que s'aborden a la discussió.

Taula 18. Valoració d'ítems dels experts en TAV. VALORACIÓ D'ÍTEMS DELS EXPERTS EN TAV

\begin{tabular}{lr}
\hline \multicolumn{1}{c}{ ÍTEM } & PUNTUACIÓ \\
\hline $\begin{array}{l}\text { La utilitat de la TAV en projectes de revitalització } \\
\text { lingüística. }\end{array}$ & $10,9,10$ i 10 \\
& \\
La utilitat de la TAV en projectes de Cl. & $8,6,8$ i 9
\end{tabular}


La utilitat de la subtitulació o subtitulació per a sords

$8,5,5$ i 8 respecte d'altres modalitats que substitueixen la banda de diàlegs original (com el doblatge) en un context de revitalització lingüística.

La utilitat de la subtitulació o subtitulació per a sords respecte d'altres modalitats que substitueixen la banda de diàlegs original (com el doblatge) en un context de $\mathrm{Cl}$.

\subsubsection{Experts en cooperació lingüística}

Les entrevistes als membres de Garabide suposen el punt de vista de dos experts en cooperació lingüística específicament. Les seues respostes estan organitzades en les següents temàtiques (v. 6.4):

1. El desconeixement de la situació de São Tomé i Príncipe.

2. El desprestigi de la llengua dels majors en altres parts del món.

3. La relació entre la situació del forro i la dels ancians.

4. La utilitat de la subtitulació.

5. Les problemes de la subtitulació.

6. Els encarregats de la subtitulació.

7. La distribució del material subtitulat.

8. Els mètodes de revitalització lingüística. 
9. Els temes de recerca futura.

Desconeixement de la situació de São Tomé i Príncipe

Tant Patxi (paràgrafs 29 i 33) com Josu (paràgraf 119) reconeixen el seu desconeixement de la situació de São Tomé i Príncipe i diuen no haver trobat mai un cas semblant en un altre país ni haver-ne sentit parlar.

Desprestigi de la llengua dels majors en altres parts del món i relació entre la situació del forro i la dels ancians

Expliquen que el desprestigi de la llengua dels majors en altres parts del món sí que sol ser habitual, ja que es considera que les llengües originàries que parlen les persones ancianes no tenen res a aportar a les noves generacions, ja que no estan preparades per als reptes digitals $\mathrm{i}$ normalment no tenen oficialitat ni presència a les administracions ni les escoles i, per tant, no és útil per a accedir a llocs de treball. En el cas de São Tomé, els dos experts coincideixen que hi ha una relació entre la situació del forro i la dels ancians (Patxi paràgraf 29 i Josu paràgraf 123).

\section{Utilitat de la subtitulació}

Tant Josu com Patxi troben la utilitat de la subtitulació en projectes de cooperació lingüística. Josu pensa que ajudaria a dignificar la llengua, tot i que troba més interessant que els subtítols siguen en forro, i observa que seria una ferramenta útil en qualsevol país amb llengües minoritàries (paràgrafs 141, 169173). Patxi ho considera molt positiu per donar presència a la llengua als mitjans de comunicació, també com a ferramenta d'aprenentatge de la llengua i aprecia que siga un mètode econòmic per portar a terme iniciatives de revitalització (paràgraf 73 ). Tot i això, Patxi 
adverteix que, per tal d'obtindre bons resultats, la subtitulació no és l'única tècnica que s'ha d'emprar, però no dona cap exemple (paràgrafs 93 i 97 ).

Pel que fa a la viabilitat de la subtitulació en projectes de cooperació en termes econòmics, ambdós pensen que podria realitzar-se fàcilment $\mathrm{i}$ que no suposaria un pressupost inassumible per a una ONG (Patxi, paràgraf 93; Josu, paràgraf 177). Josu, a més, explica que podria treballar-se amb locals, traductors més especialitzats o voluntaris, o combinar aquestes opcions (paràgraf 177).

\section{Problemes de la subtitulació}

Tot $\mathrm{i}$ les consideracions anteriors, aquests experts també assenyalen els problemes de la subtitulació. Per a Josu el fet que els subtítols siguen en portuguès podria tindre un efecte contrari al desitjat, ja que el forro no seria necessari per a entendre el contingut del vídeo $\mathrm{i}$, segons creu, podria fins i tot accelerar-se el seu desprestigi i la seua desaparició. Per tal d'evitarho, proposa que els subtítols siguen en forro per convertir-lo en una llengua necessària per a accedir a un tipus de material que resulte interessant per a la població (paràgraf 141).

Patxi, en canvi, troba tres possibles problemes diferents. En primer lloc, que s'actue en solitari, és a dir, que es pretenga revitalitzar el forro solament amb la subtitulació. Patxi insisteix que s'obtenen bons resultats quan es treballa amb diferents entitats o persones que tenen un interès comú $i$, en aquest sentit, és indispensable crear una xarxa entre camps de treball diferents que estiguen disposats a treballar per recuperar el forro amb diferents tècniques, però no especifica quines (paràgrafs $93 \mathrm{i}$ 97). 
En segon lloc, que les tècniques de subtitulació s'elaboren sense fer un estudi previ sobre quin és el contingut més adequat $\mathrm{i}$ amb quina freqüència s'exposarà el públic a aquest contingut. El primer factor és important, ja que, per a aconseguir millorar la percepció i dignificar el forro, el contingut ha de resultar interessant per al públic $i$, per tant, ha d'estudiar-se quin tipus de vídeo funcionaria a São Tomé i Príncipe, perquè probablement tenen gustos i interessos televisius diferents als d'Occident (paràgraf 109). La importància del segon factor radica en l'eficiència que puga tindre el projecte, perquè cal analitzar amb quina freqüència s'han d'exposar les persones a un vídeo subtitulat per obtenir resultats lingüístics (paràgraf 113).

Per últim, Patxi pensa que potser el fet de llegir subtítols puga resultar incòmode o complicat per a algunes persones, encara que no troba que siga un factor de pes i no li dona massa importància en comparació als esmentats anteriorment (paràgraf 109).

\section{Encarregats de la subtitulació}

Pel que fa a qui serien els encarregats de la subtitulació, Patxi proposa crear un grup de treball format per persones que tinguen interès i combinar l'activisme lingüístic i el coneixement, tant de persones que coneguen la llengua, com d'aquelles que tinguen coneixements digitals. També considera que l'administració del país hauria de participar-hi d'alguna manera (paràgraf 101). En canvi, Josu pensa que s'hauria d'implicar els locals i combinar les seues aportacions amb les de traductors professionals i voluntaris (paràgraf 177). 


\section{Distribució del material subtitulat}

Quant a la distribució del material subtitulat, els experts pensen que seria molt efectiu comptar amb la televisió i les escoles (Patxi, paràgraf 105; Josu, paràgraf 181), encara que Josu també pensa en la possibilitat d'implicar associacions i d'utilitzar internet i les xarxes socials com a instrument de difusió, encara que la ferramenta del futur és internet, ja que permet arribar als més joves a través de les xarxes socials (paràgraf 181).

\section{Mètodes de revitalització lingüística}

Josu explica que, per a aplicar mètodes de revitalització lingüística, cal que part de la població prenga consciència de la importància de la seua identitat i reivindicar la seua cultura. A partir d'aquesta base, la situació ideal és introduir la llengua en l'educació i els mitjans de comunicació, que tinga algun tipus de presència a internet i que hi haja gravacions d'acudits, contes, etc. que puguen difondre's per a possibilitar que es transmeten al si familiar (paràgraf 127).

\section{Temes de recerca futura}

Josu indica que caldria investigar les possibilitats que tindria el fet de subtitular en forro i, a més, que el material subtitulat fora un tipus de material al qual no es poguera accedir d'una altra manera i que tinguera interès per al públic en general (Josu dona l'exemple d'algun documental o pel-lícules d'animació) (paràgraf 149). Aquest expert també fa èmfasi en la importància de gravar els ancians $i$ tot el que saben per poder utilitzar aquest material en generacions més joves (paràgraf 153). Per últim, Josu pensa que el forro s'hauria d'incloure al sistema educatiu, però no per estudiar únicament la seua gramàtica i fer que 
siga una assignatura avorrida, sinó plantejar-la com una disciplina lúdica en la qual es pogueren sentir les històries dels ancians i fer activitats a partir d'aquestes històries, per exemple (paràgraf 127). En definitiva, integrar-la al currículum escolar de forma que resulte atractiva per als xiquets.

Per la seua banda, Patxi comenta que caldria analitzar detingudament la freqüència amb la qual caldria exposar el públic al material subtitulat per obtindre resultats positius, també si hi ha expressions que han de repetir-se per facilitar l'aprenentatge, si el material tindrà un component específicament didàctic o només lúdic, etc. (paràgraf 113).

Valoració d'ítems

Els experts en cooperació lingüística també van valorar una sèrie d'ítems a mode de resum de la seua opinió personal sobre els temes que es van tractar durant l'entrevista.

Taula 19. Valoració d'ítems dels experts en cooperació lingüística.

\begin{tabular}{lc}
\hline \multicolumn{2}{c}{ VALORACIÓ D'ÍTEMS DELS EXPERTS EN COOPERACIÓ LINGÜÍSTICA } \\
\hline \multicolumn{1}{c}{ ÍTEM } & PUNTUACIÓ \\
\hline $\begin{array}{l}\text { La utilitat de la TAV en projectes de revitalització } \\
\text { lingüistica. }\end{array}$ \\
$\begin{array}{l}\text { La utilitat de la subtitulació en projectes lingüístics de } \\
\text { Cl. }\end{array}$ \\
$\begin{array}{l}\text { La utilitat de la subtitulació en la sensibilització sobre } \\
\text { persones ancianes i revitalització del forro en el } \\
\text { context particular de São Tomé i Príncipe. }\end{array}$ \\
\hline
\end{tabular}


En definitiva, de la participació dels diferents experts als debats dels temes proposats (en el cas dels experts en $\mathrm{Cl}$ i TAV) i a les entrevistes realitzades (en el cas dels experts en cooperació lingüística), s'extrau la informació següent.

Al grup de discussió amb experts en $\mathrm{Cl}$, sorgeixen diferents concepcions del que és la cooperació: una activitat que es realitza des del punt de vista dels països del Nord segons les prioritats que des d'aquests països s'estableixen, i una altra que analitza les necessitats dels països en desenvolupament i actua segons aquestes necessitats que s'identifiquen.

En aquest grup, es creu de manera unànime que cal respectar la llengua del país on es treballa perquè aquest país no se senta agredit; tot i que aquesta apreciació varia quan es tracta de llengües minoritàries, perquè es considera que tenen un caràcter polític. En aquesta mateixa línia, es reconeix, per una banda, la importància de la cooperació lingüística mentre que, per una altra banda, es posa en dubte que siga un tipus d'acció prioritària. A més, alguns d'aquests experts consideren que la cooperació lingüística pot convertir les llengües en armes llancívoles, que als Governs no els interessaria i que seria una activitat conflictiva en països on es parlen moltes llengües. A més a més, per a alguns experts, la revitalització lingüística no cap en cooperació, perquè consideren que es tracta de política lingüística.

En canvi, al cas concret de São Tomé i Príncipe, sí que troben que pot ser positiu incloure iniciatives de cooperació lingüística per treballar de manera transversal la revitalització del forro i una millora en l'estatus de les persones ancianes. En aquest escenari, consideren positiu l'ús de la subtitulació, encara que també hi troben alguns desavantatges, com 
ara les despeses econòmiques que ocasionaria i que, si la població és analfabeta, els subtítols seran inútils.

Al grup d'experts en TAV, s'identifica una relació clara entre la situació del forro i la situació de les persones ancianes, i s'empatitza amb la situació lingüística per les similituds que hi troben amb la situació lingüística valenciana.

Tot i que inicialment, els experts reconeixen no saber de quina manera es podria treballar amb la TAV en projectes de Cooperació Internacional, més endavant n'aporten molts exemples: festivals de cinema com el del Sàhara, activitats d'alfabetització mitjançant la subtitulació i creació de material audiovisual en llengües minoritàries.

A tots els sembla positiva la idea d'utilitzar subtítols en portuguès amb l'àudio en forro al cas de São Tomé, amb l'objectiu d'acostar al públic la llengua i donar visibilitat a les persones ancianes. Consideren que la subtitulació és útil per acostar els ancians i el forro a la població, especialment als xiquets i les xiquetes.

Els possibles problemes que aquests experts preveuen en la subtitulació són la dificultat per llegir que puga tindre el públic, qui s'encarregaria de realitzar els subtítols i el debat d'utilitzar subtitulació o doblatge. Per a un dels experts, en canvi, el problema més greu seria convèncer la gent perquè veja el programa.

Quant a l'acceptació de la subtitulació, els experts no dubten que tindria una bona acollida, encara que es tracta d'una modalitat que, sovint, resulta incòmoda al principi. Segons una de les expertes, pocs minuts després el públic sol habituar-se i veuen programació subtitulada amb normalitat. 
Per últim, aquests experts proposen una sèrie de temes de recerca futura: un taller d'introducció a la llengua, el doblatge de dibuixos animats amb els ancians com a actors i actrius de doblatge, les possibilitats de doblar tant material nacional com internacional, la realització de programes culturals amb les persones ancianes com a protagonistes i establir unes convencions de subtitulació específiques per a São Tomé i Príncipe.

Els experts en cooperació lingüística desconeixien la situació de São Tomé i Príncipe, però confirmen que el fet que la llengua dels majors estiga desprestigiada és bastant comú arreu del món i, per tant, pensen que la decadència del forro i l'exclusió de les persones ancianes estan relacionades.

Aquests experts troben que la subtitulació és una eina econòmica que pot ajudar a dignificar la llengua i a facilitar el seu aprenentatge. En canvi, consideren que no ha de ser l'única ferramenta per treballar en favor del forro, i que ha de preparar-se amb molta cura de quina manera es desenvoluparia. També hi ha un cert temor per part d'un dels experts que el fet que els subtítols siguen en portuguès faça l'efecte contrari al desitjat, ja que el forro no seria necessari per a comprendre el contingut del vídeo.

En cas d'aplicar-se, consideren que els encarregats de subtitular hauria de ser un equip conformat per persones locals, traductors professionals, voluntaris, etc., per a poder combinar el coneixement i l'activisme. Quant a la distribució, assenyalen la importància de la televisió, les escoles i internet.

Per tal que tinga èxit un programa de revitalització lingüística, els experts creuen necessari que el forro s'incloga al sistema educatiu i als mitjans de comunicació, però també que es realitzen més gravacions d'ancians per tindre material 
de treball. Per últim, indiquen alguns temes de recerca futura: les possibilitats de subtitular en forro algun contingut que resulte interessant al públic, i que no puguen entendre d'altra manera; enregistrar més ancians parlant en forro; introduir el forro a l'escola de forma lúdica i que es treballe a partir de les històries dels ancians; i estudiar quina seria la freqüència, el contingut i la temàtica més convenient per als vídeos.

Una vegada s'ha realitzat aquest exercici de triangulació amb els tres grups d'experts, al qual s'han exposat els resultats obtinguts al terreny, cal analitzar les aportacions que s'han recollit i extreure una sèrie de conclusions i possibles futures línies d'investigació. La utilització de la triangulació de dades en aquest cas corrobora algunes premisses d'aquesta tesi, en puntualitza unes altres i també ofereix noves perspectives de treball, que es defineixen al capítol següent. 


\section{CONCLUSIONS}

Aquesta tesi pretenia comprovar si la TAV i, més concretament, la subtitulació, pot ser una ferramenta activa i útil en projectes de sensibilització en l'àmbit de la cooperació en São Tomé i Príncipe. El desenvolupament de la investigació indica que sí que podria implementar-se amb resultats positius. Les respostes de les persones participants de São Tomé i Príncipe i dels experts consultats, recollides a través de les entrevistes i els grups de discussió, resulten indispensables, ja que aporten diferents opinions que es complementen per oferir una visió més completa de la situació dels ancians, del crioll forro i del paper que pot jugar la subtitulació per pal-liar-les. A més, els experts aporten les seues reflexions sobre els beneficis i les dificultats que pot tindre la utilització dels subtítols i d'altres modalitats de TAV en el camp de la $\mathrm{Cl}$ i la revitalització lingüística. En aquest capítol, per tant, es presenta una proposta de treball d'acord amb els resultats obtinguts $i$ les conclusions finals de la investigació que serveixen per a validarla i comprovar si s'aconsegueixen els objectius i es validen les hipòtesis que s'havien plantejat a l'inici de la investigació. Per últim, es presenten propostes d'algunes línies d'investigació que podrien desenvolupar-se en un futur.

\subsection{CONCLUSIONS DEL TREBALL AL TERRENY I DE L'OPINIÓ DELS EXPERTS}

A continuació es presenten les conclusions que s'han pogut extraure de les entrevistes a persones ancianes i a persones no ancianes de São Tomé, i dels grups de discussió i les 
entrevistes realitzats a experts en $\mathrm{Cl}$, TAV i cooperació lingüística. Com es pot veure, moltes d'aquestes conclusions entrellacen les opinions de diferents participants respecte a les persones ancianes de São Tomé i Príncipe, la percepció del forro, la cooperació lingüística i l'ús de la TAV i entre totes donen forma, a mode de conclusió final, a la proposta que es presenta en l'apartat 8.2.

\subsubsection{La situació de les persones ancianes}

La primera conclusió que s'extrau de les entrevistes a les persones ancianes és que hi ha una pèrdua cultural a la societat, tant pel que fa a les danses com a les cançons o les celebracions -el Bokadu o el txiloli, per exemple- (v. 7.1). Aquesta idea expressada al vídeo es veu reforçada per l'experiència que manifesten les persones no ancianes en tots els grups d'edats (v. 7.2.1, 7.2.2, 7.2.3, i 7.2.4).

Les entrevistes amb les persones ancianes descobreixen que la relació que antigament es tenia amb els ancians ha canviat. Segons explica Fernando, abans el veïnat els cuidava i eren figures de respecte, fins al punt de parlar-los amb la mà al pit com un reconeixement especial o permetre'ls que castigaren els xiquets quan es portaven malament (v. 7.1). És clar que aquesta tesi no pretén defensar el maltractament físic com a forma de disciplina, però conéixer aquest fet sí que ajuda a comprendre quin era el rol social de les persones ancianes antigament i com és ara de diferent. Un altre exemple que explica Fernando és que el veïnat enviava els xiquets perquè portaren menjar als ancians i podien dinar amb ells i fer-los companyia, mentre que ara ja no es fa, per por que danyen d'alguna manera els infants (v. 7.1). Açò ho corrobora Mafalda (entre 20 i 30 anys), que explica que antigament s'ajudava les persones ancianes a fer els treballs que els podien resultar pesats $i$, de vegades, els ancians els 
convidaven a menjar alguna cosa com a agraïment i menjaven junts; mentre que ara, cap mare vol que els seus fills passen temps amb persones ancianes ni que mengen res que els hagen oferit (v. 7.2.2).

En contrastar totes les intervencions, resulta evident que com més joves són els participants, menys coneixements culturals del país tenen. Especialment quan se'ls pregunta si els seus fills coneixerien les mateixes tradicions 0 cançons que ells i molts responen que no (v. 7.2.1, 7.2.2, 7.2.3, 7.2.4). Açò donaria credibilitat a allò que explica Amélia sobre el rol perdut de les persones ancianes, de com afecta la transmissió cultural de les famílies i justifica el treball amb xiquets en cas que es vulga fomentar la conservació de les tradicions de São Tomé i Príncipe (v. 7.2.4), i les propostes d'iniciatives per a promoure el rol de les persones ancianes.

Per una banda, totes les persones participants no ancianes, independentment del grup d'edat al qual pertanyen, reconeixen la discriminació envers els ancians de rendiments més baixos. Cal ressaltar l'opinió de Matilde, que assenyala una major discriminació a dones que a homes (v. 7.2.3), i la d'Evaristo, que creu que els ancians a qui es discrimina ara no han sabut transmetre als seus fills l'exemple d'atendre als majors de la família (v. 7.2.2). En aquest sentit, Amélia parla del rol que han perdut els avis a les famílies, perquè ja no compleixen la funció de cuidar els nets i contar-los històries. Açò, segons Amélia, no només contribueix a l'abandonament dels ancians per part dels seus familiars, sinó que també allunya els joves de la cultura del seu país per no haver tingut l'experiència d'algú que els l'explique (v. 7.2.4). Per una altra banda, hi ha el testimoni de Celia (v. 7.3.1), experta en Cooperació Internacional, que explica com algunes persones ancianes s'emocionaven quan els xiquets els parlaven en forro. Tenint en compte aquestes consideracions, tindria sentit 
desenvolupar projectes que treballaren amb els xiquets i també amb les famílies amb l'objectiu de retornar l'antic rol del qual parla Amélia als ancians i contribuir a un canvi de paradigma proposant-los com a font de saviesa insubstituïble i mereixedors de respecte i atenció. Un altre expert en Cooperació Internacional, César, proposa organitzar concursos de poesia, recopilacions de refranys i contes, que els ancians ho expliquen als xiquets, etc.(v. 7.3.1). Aquesta idea també està en la línia de la proposta d'aquesta tesi (v. 8.2) i podria formar-ne part o realitzar-se com una iniciativa diferent, però complementària. En cas que s'organitzen els concursos i les activitats que proposa César (v. 7.3.1), seria interessant que s'enregistraren per a emetre'ls subtitulats per televisió i difondre aquest contingut, la qual cosa coincidiria amb la importància d'enregistrar el màxim material possible en forro que assenyala Josu, un dels experts en cooperació lingüística (v. 7.3.3).

Tots els participants no ancians de São Tomé i Príncipe troben una relació entre la situació de les persones ancianes, del forro $i$ de la pèrdua de tradicions del país (v. 7.2.1, 7.2.2, 7.2.3, i 7.2.4). També ho fan la majoria d'experts. Encara que al grup d'experts en $\mathrm{Cl}$, només Esther troba aquesta relació entre la situació dels ancians, del forro i de la pèrdua de tradicions (v. 7.3.1), tots els experts en TAV i els experts en cooperació lingüística veuen aquesta connexió (v. 7.3.2; 7.3.3). Per tant, sí que tindria sentit unificar aquests tres conceptes per desenvolupar projectes de $\mathrm{Cl}$ que els aborden de manera transversal, com proposa aquesta tesi.

\subsubsection{La percepció del forro}

Una de les conclusions que es desprén del testimoni de Graça i de Fernando és la concepció del forro com 
una llengua adequada per als adults, però que no és correcta per als xiquets, que han de parlar en portuguès (v. 7.1). Aquesta conclusió també es pot extraure d'algunes de les opinions de les persones no ancianes, com ara la de Wilson (entre 20 i 30 anys), que no li parla forro a la seua filla perquè la considera massa xicoteta (v. 7.2.2), i Alda (entre 30 i 40), que tampoc para forro als seus fills perquè pensa que el portuguès és la llengua més correcta per a dirigir-se als xiquets (v. 7.2.3).

En canvi, tot i pensar que el forro no és una llengua adequada per als xiquets i que la llengua que se'ls ha de parlar és el portuguès, es considera que a l'escola hauria d'ensenyar-se forro. Aquesta és l'opinió de Fernando, que creu que a l'escola també s'haurien d'aprendre les coses del país (v. 7.1). De la mateixa manera, a tots els entrevistats nascuts a São Tomé i Príncipe els agradaria que s'estudiara forro a l'escola (v. 7.2.1, 7.2.2, 7.2.3, 7.2.4). Fins i tot Matilde (entre 30 i 40 anys) creu que el forro s'aprendria millor a l'escola que a casa (v. 7.2.3). De fet, Elmer (v. 7.2.1), i Amélia (v. 7.2.4) identifiquen la llengua vehicular en l'ensenyament (el portuguès) com el motiu principal pel qual els pares que saben forro ja no el transmeten als fills. No es tracta, per tant, d'un rebuig visceral cap a una llengua sinó que, d'alguna manera, per la voluntat dels pares d'oferir un futur educatiu de qualitat als seus fills i, per tal de facilitar-los el camí, aquests han optat per deixar de banda el forro i substituir-lo pel portuguès. Aquesta dinàmica està tan normalitzada que alguns entrevistats com Alda se sorprenien amb la pregunta de per què no parlaven forro als fills, perquè els semblava evident que no era una possibilitat, encara que sí que trobava molt positiu que la llengua s'ensenyara a l'escola, com ja s'ha esmentat (v. 7.2.2). Les escoles, per tant, serien clau per fomentar l'ús del forro i, d'acord amb les respostes dels entrevistats, sembla que no hi hauria una confrontació amb els pares per aquest motiu. 
Un altre aspecte que crida l'atenció de les contribucions dels entrevistats i les entrevistades de São Tomé és la noció que es té de llengua materna. En un principi, molts d'ells identifiquen el forro com la seua llengua materna, però segons es desenvolupa l'entrevista expliquen que no saben parlar-lo molt bé o que a ells els van criar en portuguès. Paral-lelament, tant a les entrevistes com en converses posteriors, és comuna la referència al forro com a llengua nacional, llengua de São Tomé o llengua de la terra. Seria interessant investigar si les raons d'aquesta associació del forro amb el terme llengua materna responen a una identificació ètnica, a una vinculació amb la figura materna, o a uns altres motius (Mills, 2004). Cal afegir que les persones que reconeixen no parlar forro amb els fills perquè els pareix que el portuguès és una llengua més correcta i que utilitzen el portuguès en tots els àmbits de la seua vida, també mostren obertament el seu orgull per l'existència del forro i la seua voluntat que s'estudie i tinga més presència als mitjans de comunicació.

\section{S'entreveu una clara situació de diglòssia}

entre el forro i el portuguès de què els entrevistats són conscients. La majoria d'entrevistats identifica el portuguès com la llengua per fer gestions amb un registre més alt, com ara anar al metge (v. 7.2.1, 7.2.2, 7.2.3, i 7.2.4), excepte tres joves de menys de 20 anys (Abigail, Flávia i Miguel) i un entre 20 i 30 (António). No obstant això, tots aquells que tenen fills, els parlen en portuguès (v. 7.2.1, i 7.2.2). Crida l'atenció l'opinió de Mafalda (entre 20 i 30 anys), que reconeix que haurien de parlar més forro, però que en realitat la llengua que més s'utilitza és el portuguès ( $v$. 7.2.2); i la d'Amélia (entre 40 i 50 anys), que proposa que els professionals sanitaris sàpiguen forro per poder atendre les persones que se senten més còmodes utilitzant aquesta llengua (v. 7.2.4). Tot i això, sorprén l'actitud reivindicativa en favor del forro per part d'algunes de les persones entrevistades a causa de la seua joventut (v. 7.2.1, 
7.2.2), la qual cosa no deixa de ser un senyal esperançador per encetar treballs de revitalització o normalització lingüística, ja que es pot veure que hi ha joves interessats en el fet que el forro no es perda.

Alguns dels entrevistats de São Tomé majors de 20 anys identifiquen el forro com una llengua per a cantar i fer bromes. Per una altra banda, alguns d'ells especifiquen que, en cas que s'integre el forro a l'escola, hauria de fer-se de forma divertida i no com una assignatura a l'ús (v. 7.2.2, 7.2.4). Combinant aquestes dues opinions, que reforça un dels experts en cooperació lingüística (v. 7.3.3), es pot entendre que la introducció de cançons, d'acudits i de contes seria un bon començament per al forro en l'àmbit educatiu i, seguint la temàtica d'aquesta tesi, fa que cobre sentit l'activitat que es proposa en l'apartat 8.2.

\subsubsection{La cooperació lingüística}

Una de les conclusions que s'extrauen de la discussió d'experts en $\mathrm{Cl}$ és la necessitat de formació en diversitat lingüística als cooperants. En primer $\| \mathrm{oc}$, tots els experts en $\mathrm{Cl}$ consultats estan en contra de la imposició d'unes llengües sobre altres, consideren que són un bé cultural de tota la humanitat i que la cooperació lingüística s'hauria de tindre més en compte d'acord amb la seua valoració d'ítems (v. 7.3.1), però es detecta un canvi de posicionament quan es parla de llengües minoritàries. Comenten, per exemple, que la revitalització lingüística pot desintegrar nacions, que és costosa, que pot ser conflictiva, etc.

En segon Iloc, alguns experts consideren que la cooperació lingüística no és un tipus de cooperació prioritària en països en vies de desenvolupament i que, a més a més, la revitalització lingüística no seria cooperació, sinó política lingüística i pertany a cada Govern. En canvi, sorgeixen dubtes a partir 
d'aquesta afirmació sobre on es troba la línia divisòria d'allò que pertany a la cooperació i el que correspon al Govern d'un país. És inevitable establir un paral-lelisme amb les investigacions de Birello i Sánchez-Quintana (2014); Carrasco i Sánchez-Quintana (2013) i Requena et al. (2009), que conclouen que les creences lingüístiques dels docents els porten a determinants continguts didàctics, de la mateixa manera que les creences lingüístiques dels experts en $\mathrm{Cl}$ els poden portar a determinades postures envers la cooperació lingüística. En principi, aspectes com l'assistència sanitària, la seguretat alimentària, les infraestructures, etc. estan sota la responsabilitat dels governants d'un país i, en canvi, no hi ha debat sobre la idoneïtat que la $\mathrm{Cl}$ treballe en aquests àmbits. Per què, aleshores, la revitalització lingüística no té espai a la $\mathrm{Cl}$ si pot ajudar a millorar la vida de certs grups de persones?

En tercer lloc, alguns experts també assenyalen com a inconvenients de la cooperació lingüística que els Governs dels països beneficiaris no voldrien col-laborar. Aquesta última consideració contrasta amb l'experiència de treball a São Tomé i Príncipe de l'ONG Cooperación Bierzo Sur, que sovint desenvolupa projectes sense col-laboració governamental directa i no en suposa un problema per a l'organització i l'execució (Álvarez, comunicació personal, 2019). En alguns casos, és suficient amb una autorització de treball per part del Ministeri al qual pertany el projecte. Sorprén, per tant, que es considere la necessitat de participació governamental directa quan es parla d'iniciatives de cooperació lingüística.

Aquesta conclusió ens condueix a una segona si s'enllacen aquestes opinions dels experts amb el debat que mantenen Begoña i Celia sobre la cooperació amb punt de vista occidental (v. 7.3.1), al qual Begoña troba raonable que les entitats internacionals marquen les necessitats de cooperació, sovint amb la 
visió cultural dels països del Nord, mentre Celia creu que ha de treballar-se en allò que el país vertaderament necessita, independentment de l'agenda d'altres organismes. Potser aquest és el motiu pel qual els experts més oberts a tipus de cooperació alternatives entre els participants són aquells que treballen amb una nova visió del que significa $\mathrm{Cl}$, com Celia i Esther. Segurament, al primer tipus de cooperació, que defensa Begoña, la cooperació lingüística no té cabuda i les organitzacions que siguen proclius a aplicar el tipus d'iniciatives que es proposen en aquesta tesi sense haver rebut la formació en diversitat lingüística que s'ha proposat anteriorment, siguen només aquelles que coincideixen amb la mateixa idea de cooperació que té Celia, és a dir, una cooperació centrada en allò que els països necessiten, independentment d'altres agendes o interessos externs.

César troba que la revitalització lingüística pot desintegrar una nació en donar als parlants un cert estatus i convertir les llengües en armes llancívoles. Entenem que els conflictes polítics que puguen sorgir de la revitalització lingüística procedeixen d'una situació política conflictiva ja existent, i que el foment d'una llengua no seria el causant del conflicte polític, sinó un element afegit. Hui en dia, a São Tomé no hi ha situacions polítiques o socials que puguen agreujar-se o causar revoltes pel fet de revitalitzar el forro i, per tant, aquest problema que preveu César no s'aplicaria. Per la seua part, Begoña explica que hi ha països amb més de 300 llengües i que podria ser problemàtic el fet de prioritzar la revitalització d'una llengua per sobre les altres (v. 7.3.1), és a dir, és possible que la cooperació lingüística no siga una eina amb el mateix grau d'utilitat a tots els països, com també es desprén de l'àmplia varietat de baremació amb què els experts en $\mathrm{Cl}$ van valorar l'ítem de si la cooperació lingüística seria útil en algun dels països on han treballat (v. 7.3.1). Segurament, aquesta varietat es deu a la dificultat que alguns opinen que tindria la cooperació lingüística en 
països on es parlen moltes llengües. Per tant, caldria adaptar cada projecte a les necessitats i les condicions del país o la zona en particular on es pense treballar $i$ avaluar si la cooperació lingüística és viable o no en cada cas.

\subsubsection{L'ús de la TAV}

A tots els entrevistats no ancians de São Tomé els agrada l'experiència de veure un vídeo en forro subtitulat $i$ diuen que els agradaria veure més programació en aquest format (v. 7.2). Fins i tot menciona això Alda, que explica que normalment no li agrada perquè, quan hi ha programació subtitulada a la televisió, no li dona temps de llegir (v. 7.2.3). Aquest testimoni justifica la necessitat d'adaptar unes convencions de subtitulació específiques per a aquest país o per a països amb característiques semblants, encara que s'allunyen de les tradicionalment establertes $\mathbf{i}$ tinguen com a resultat uns subtítols desiguals, més breus o menys estètics, la qual cosa és consistent amb els resultats obtinguts per Kruger et al. (2007) (v. 2.4). Per a establir els paràmetres de subtitulació dels vídeos utilitzats en aquesta tesi ja s'ha fet una primera proposta d'adaptació de les convencions habituals que ha donat bons resultats, com s'explica en l'apartat 6.5. No obstant això, la principal limitació del procediment seguit és la reduïda mostra de participants en l'estudi de recepció, ja que s'han adaptat les convencions a partir de les opinions d'una única persona. Per tal de comprovar si les convencions proposades ací són útils per a la majoria de la població, caldria dissenyar un estudi a major escala amb una mostra representativa de la societat de São Tomé i Príncipe.

A més a més, diferents participants no ancians de tots els grups d'edat creuen que la subtitulació facilitaria l'aprenentatge de forro (v. 7.2.1, 7.2.2, i 7.2.3) o, com indica Amélia, 
per no excloure ningú (v. 7.2.4). D’acord amb l'opinió d'aquests 16 entrevistats, llavors, l'exposició a material en forro subtitulat tindria una bona acollida per part de la població, ja que, sense tindre coneixements acadèmics, intueixen que és una eina útil per a l'aprenentatge i la visibilitat d'una llengua. Tot i l'escepticisme d'un dels experts en $\mathrm{Cl}$ pel que fa a la utilitat de la subtitulació en l'aprenentatge de llengües (v. 7.3.1), els experts en TAV i els experts en cooperació lingüística defensen aquesta opció com a ferramenta per a l'aprenentatge de llengües (v. 7.3.2, 7.3.3). A més, com s'ha exposat en l'apartat 2.3, diversos investigadors han demostrat als seus estudis que, efectivament, la subtitulació pot emprar-se com a eina d'aprenentatge de llengües amb resultats molt positius.

Quant al paper de la subtitulació en projectes de cooperació lingüística, César, un dels experts en $\mathrm{Cl}$ assenyala que suposaria un problema econòmic, ja que ho considera una activitat costosa. En realitat, com s'ha explicat al capítol 2.1, no ho seria tant, ja que hi ha programes disponibles que són gratuïts i fàcils d'utilitzar. A més, l'opinió d'aquest expert contrasta amb la dels experts en cooperació lingüística (v. 7.3.3) que, precisament, identifiquen com un dels principals avantatges de la subtitulació que es tracta d'una eina econòmica. Així i tot, la puntuació que els experts en $\mathrm{Cl}$ donen a l'ús de la subtitulació és bastant positiva, com es pot veure a la valoració del quart i cinquè ítem (v. 7.3.1), la qual cosa reforça la proposta d'aquesta tesi. Aquest ítem també rep puntuacions altes al grup d'experts en TAV (v. 7.3.2).

Per la seua banda, Ruth, experta en $\mathrm{Cl}$, manté que la subtitulació no és una eina útil perquè la majoria de persones a São Tomé i Príncipe no saben llegir i hi ha molts xiquets sense escolaritzar (v. 7.3.1). L'opinió de Ruth es basa en la seua pròpia experiència al país i és sens dubte valuosa, ja que el seu 
treball consistia a realitzar un cens de persones amb discapacitat, la qual cosa implicava visitar casa per casa les famílies en què hi havia membres amb algun tipus de discapacitat per entrevistar-les. No obstant això, a continuació es puntualitzen l'època, la duració d'estada i les zones de treball en les quals va participar per poder comparar-les amb les dades oficials.

Segons explica Álvarez (comunicació personal, 2019), presidenta de I'ONG amb la qual va viatjar Ruth, aquest cens es va realitzar l'any 2014, de mitjans de juliol a mitjans d'agost al districte d'Água Grande. En comparació, les dades de I'Instituto Nacional de Estatística que indiquen un nivell d'alfabetització del 90,1\% són de l'any 2018 i abracen tot el país (v. 5.3). Potser durant els quatre anys de diferència entre l'experiència de Ruth el 2014 i les dades oficials de 2018 es van donar canvis substancials en les polítiques educatives del país que justifiquen aquesta discrepància. A més, com assenyala Álvarez, cal tindre en compte que Ruth tractava específicament famílies amb membres amb algun tipus de discapacitat i potser la dificultat d'aquestes persones per accedir a l'escola feia que hi deixaren d'assistir i foren analfabetes. En aquest sentit, cal tindre en compte que les dades oficials (Instituto Nacional de Estatística, 2018) no especifiquen la situació de les xiquetes i els xiquets amb discapacitat en comparació amb la de les xiquetes $\mathrm{i}$ els xiquets sense discapacitat. Álvarez també adverteix que, tot i els esforços de l'administració de São Tomé i Príncipe, que intenta posar facilitats per tal que les mares puguen registrar els nadons després de donar a llum, fins i tot hui dia hi ha famílies que no registren els fills. D'acord amb aquesta informació, les dades oficials han de prendre's amb certa relativitat $i$, en conseqüència, és molt possible que la xifra d'escolaritat no siga tan alta com la que presenten les dades oficials ni tampoc tan pessimista com la que va percebre Ruth. La seua experiència és important perquè posa llum en una necessitat més 
del país i que podria ser una nova branca de recerca: la necessitat de comprovar i actualitzar la situació dels estudiants amb discapacitat i de quina forma es diferencia de la d'aquells que no tenen discapacitat. A més a més, una experta en TAV assenyala la utilitat de la subtitulació com a ferramenta per a l'alfabetització (v. 7.3.2). Aquesta opció resulta molt interessant si s'enllaça amb el que comenta Ruth sobre l'analfabetisme a São Tomé i Príncipe, perquè ofereix opcions de treball dirigides també a persones que no sàpiguen llegir ni escriure. Aquesta variant, però, necessitaria una investigació pròpia i un cens més detallat per a establir un pla de treball adient.

Un altre benefici de la subtitulació que troben dues expertes en TAV és que pot servir per a acostar la situació dels ancians i del forro a la població que, en veure aquests temes integrats a la televisió, ja no els trobarien tan llunyans i es reduiria el rebuig contra la llengua i les persones ancianes. Una altra experta del mateix grup pensa que els xiquets són necessaris per a recuperar la llengua i, en aquest sentit, la subtitulació jugaria un paper important per facilitar-los la comprensió del forro (v. 7.3.2). Aquestes opinions reforcen la proposa d'aquesta tesi, que s'especifica a l'apartat 8.2.

Tots els experts en TAV pensen que la TAV podria tindre una incidència positiva a São Tomé i Príncipe. Clara i Mar pensen que pot haver-hi un canvi de percepció envers el forro i, a més, Clara creu que la TAV pot ser una forma divertida de facilitar que els xiquets aprenguen la llengua. Coincideix, per tant, amb la proposta d'Alda (v. 7.2.3) que s'emeta un programa infantil per a iniciar els xiquets en l'aprenentatge de forro, i també amb la proposta d'aquest treball (v. 8.2). 
Al grup d'experts en TAV, Marina proposa un programa en el qual es visiten ancians de diferents parts del país i que siguen ells els que expliquen en forro característiques culturals d'eixa zona (gastronomia, música, etc.). Clara i Jordi plantegen la possibilitat de fer un cinema itinerant. Tots estan d'acord que el més positiu seria combinar contingut produït a São Tomé i Príncipe amb contingut estranger. Jordi proposa projectar una pel-lícula comercial doblada en forro i subtitulada en portuguès $i$, abans que comence, passar un curtmetratge o campanya governamental sensibilitzant sobre la situació de les persones ancianes. Mar afegeix que també podria fer-se un taller d'introducció a la llengua amb nocions bàsiques. El fet que les propostes més variades per integrar la TAV per a fer cooperació a São Tomé i Príncipe vinguen del grup de traductors, sense experiència en $\mathrm{Cl}$, porta a una nova conclusió: seria positiu elaborar un equip mixt per tal que cada expert contribuïra al projecte amb els coneixements del seu àmbit, o utilitzar la metodologia dels grups de discussió a l'hora de preparar la planificació del projecte de cooperació. Aquesta conclusió també la consoliden els experts en cooperació lingüística (v. 7.3.3), que creuen que hauria de crear-se un grup de treball format per persones que volen participar en un activisme lingüístic, persones que saben forro i persones amb coneixements digitals. Consideren important que s'impliquen persones locals i que es combinen els seus coneixements amb els de traductors professionals. Un d'ells també creu que és necessària la participació de l'administració del país. Aquestes opinions reforcen la idea de crear equips multidisciplinaris perquè els projectes resulten sostenibles (v. 4.2.2) i eficaços, indispensable per a l'obtenció de resultats satisfactoris.

Jordi, traductor audiovisual, considera que la utilitat de la subtitulació esdevindrà quan ja hi haja una base de revitalització lingüística, no abans. Aquesta opinió enllaça amb la 
dels experts en cooperació lingüística (v. 7.3.3), que adverteixen que la subtitulació no ha de ser l'única tècnica que es contemple per treballar en favor del forro. Açò és molt important, ja que el plantejament d'aquesta tesi suposa una proposta d'ús de la TAV com a eina per a la cooperació a São Tomé i Príncipe, però no una eina única. En conseqüència, la TAV hauria d'integrar-se en un programa més ampli planificat amb un objectiu concret (com el que es presenta en aquesta investigació) per tal d'obtenir resultats positius. Allò ideal seria comptar amb la col-laboració d'entitats que també estigueren interessades a millorar la situació cultural del país o la situació de les persones ancianes i fer esforços conjunts per treballar en aquesta línia.

Una altra qüestió problemàtica per a Jordi seria convèncer la gent perquè mire el vídeo subtitulat. Evidentment, és impossible assegurar que totes les persones voldrien veure vídeos en forro als quals apareixen persones ancianes, però com indiquen altres experts d'aquest grup, es tractaria de crear vídeos que siguen d'interès per a la població. Com es recull d'alguns entrevistats de São Tomé i Príncipe (Mafalda i Amélia, per exemple), a l'època en la qual es van realitzar les entrevistes per a aquesta investigació, s'emetia un programa de televisió en forro sobre societat en to humorístic que tenia molt d'èxit. La clau estaria, per tant, que el contingut dels vídeos fora d'interès per a les persones a qui va dirigit, en la línia que assenyalen Marina i Mar en intervencions anteriors (v. 7.3.2), i també seguint el criteri d'un dels experts en cooperació lingüística (v. 7.3.3). Partint d'aquestes opinions, caldria començar per decidir com seria el vídeo que se subtitularia: infantil, humorístic, cultural, educatiu, si tindrà contingut musical, etc. A continuació, seria necessari estudiar amb quina freqüència es podria emetre. Açò depén de la forma de difusió, ja que, en cas que s'utilitzara la televisió, caldria negociar l'horari i els dies d'emissió, publicitar el programa, etc. Si es planteja 
com una projecció itinerant a les escoles, també caldria estudiar a quina franja d'edat va dirigit; si ha de presentar-se a alumnes de primària, de l'institut o a la universitat; la freqüència en què ha d'emetre's perquè siga efectiu; negociar amb el professorat $i$ el Ministeri d'Educació per tindre la seua col-laboració i que puga projectar-se en hores de classe $i$ també assegurar el transport fins a les escoles per a portar la projecció; elaborar un calendari per saber quan es mostra el vídeo a les diferents zones del país, etc. En cas de plantejar el projecte com un cinema itinerant, també caldria negociar amb el Ministeri corresponent $\mathbf{i}$ arribar a acords quant a un calendari per saber quan es projecta $i$ on, $i$ assegurar el transport per fer arribar la projecció a les diferents comunitats.

Clara, experta en TAV, apunta la necessitat de fer un estudi específic per a saber quines serien les convencions de subtitulació més adequades per a les persones de São Tomé i Príncipe. Encara que en aquesta tesi aquesta problemàtica es resol d'una manera més o menys domèstica (amb l'ajuda d'una persona coneguda) i que podria repetir-se per a un projecte menut i focalitzat en una zona molt concreta del país, en cas de pretendre una emissió continuada a la televisió o un cinema itinerant amb certa regularitat, sí que caldria fer un estudi que permeta establir aquestes convencions específiques per a facilitar el procés de subtitulació, com s'ha esmentat anteriorment.

Per a un dels experts en cooperació lingüística, en canvi, seria més interessant que els subtítols foren en forro a partir d'un àudio en una llengua estrangera per tal de donar al forro l'exclusivitat de ser clau per poder entendre el vídeo. Pensa que, si els subtítols són en portuguès, podria perjudicar-se al forro, ja que no seria necessari per a entendre el contingut dels vídeos. Com s'explica en l'apartat 2.3, contràriament al que pensa aquest expert, 
els subtítols en portuguès d'un àudio en forro també poden contribuir a l'aprenentatge de forro de manera efectiva, encara que la seua proposta també mereix ser analitzada i esbrinar les possibilitats i la repercussió que tindria a São Tomé el fet d'aplicar la combinació lingüística inversa.

Encara que a la valoració d'ítems els experts en TAV valoren positivament l'ús de la subtitulació al cas particular del forro i els ancians de São Tomé i Príncipe (v. 7.3.2), Mar especifica que el material amb àudio en forro tindria una major incidència encara que no es tractara de produccions pròpies del país, i proposa doblar en forro material interessant per al públic i subtitular-lo en portuguès. En aquesta proposta entraria també el doblatge que, en principi no s'havia tingut en compte en aquesta tesi per motius econòmics, però sembla que els experts en TAV no troben massa dificultats a posar-ho en pràctica en un país com São Tomé i Príncipe. Pel que fa a qui doblaria, Mar proposa que ho facen els ancians a través de tallers de doblatge, la qual cosa resulta molt interessant, sobretot des del punt de vista de la cooperació en favor de les persones ancianes, encara que caldria estudiar les possibilitats econòmiques, de materials $i$ de sostenibilitat que tindria aquest projecte.

També en relació amb l'ús del doblatge a São Tomé i Príncipe, cal ressaltar les possibilitats que troben els experts en traducció en el cas del doblatge a São Tomé i Príncipe i que es reflecteixen en la valoració d'ítems (v. 7.3.2). A més, es comenta, entre altres coses, que el doblatge pot ser una bona eina per rehabilitar llengües quan no hi ha alfabetització. Com s'ha comentat amb la utilitat de la subtitulació per a l'alfabetització, podria estudiar-se el seu ús en cas que fora necessari, com sospita Ruth, del grup d'experts en $\mathrm{Cl}$. En qualsevol cas, com també s'indica anteriorment, caldria realitzar un estudi específic per tindre una 
premissa més sòlida sobre les possibilitats, l'acollida i els possibles resultats d'aplicar el doblatge d'aquesta manera.

Per a Marina, es podria analitzar la possibilitat de fer un programa en forro de jocs o cançons tradicionals dirigit a xiquets que presentarien persones ancianes. Mar proposa un taller d'introducció a la llengua per facilitar l'aprenentatge de conceptes bàsics; el doblatge de dibuixos animats amb els ancians com a actors i actrius de doblatge i, per últim, doblar tant material propi de São Tomé i Príncipe com material estranger que puga ser atractiu per al públic. Pensa que seria interessant doblar-lo al forro i subtitular-lo en portuguès. Totes aquestes idees resulten prometedores per a la integració de la TAV a la cooperació, ja que suposen una via per donar un rol d'importància a les persones ancianes i integrar-les així en la societat posant el focus en els coneixements que poden transmetre als més joves (tant lingüístics com culturals).

Pel que fa a la distribució del material, els experts en cooperació lingüística troben imprescindibles la televisió i les escoles, encara que un d'ells també proposa implicar associacions del país i utilitzar internet i les xarxes socials per arribar als joves. De nou, sorgeix aquesta idea de donar al forro un espai a les noves tecnologies i un paper al món digital de l'actualitat com ja s'havia plantejat en parlar del desprestigi de la llengua dels majors en altres parts del món (v. 7.3.3) i caldria, sense dubte, tindre-la en compte a l'hora de desenvolupar treballs que impliquen la revitalització del forro. De fet, ja existeixen comunitats d'indígenes que han pensat en la importància de les noves tecnologies per a conservar la seua cultura i el seu entorn, i les utilitzen de formes diferents amb aquest objectiu. La sèrie documental Tribus XXI (Jego et al., 2016) mostra alguns exemples, com ara els wauras de Brasil, que han aprés a enregistrar i editar vídeos per a gravar la seua 
forma de viure dia a dia per tal que no es perden els seus costums ni el seu entorn, o els San de Namíbia, que utilitzen un programa informàtic per a tindre una base de dades dels animals de l'entorn i poder entendre i conservar així la biodiversitat que els envolta, entre altres casos.

Pel que fa a la valoració d'ítems que fan els experts en cooperació lingüística sobre la utilitat de la TAV (v. 7.3.3), encara que totes les puntuacions superen l'aprovat i, per tant, poden considerar-se positives, no són molt altes comparades amb les puntuacions d'altres experts. Per explicar aquestes valoracions cal recordar que, com bé indiquen durant l'entrevista, la subtitulació no pot ser una ferramenta única de revitalització lingüística o $\mathrm{Cl}$, sinó que s'ha de treballar conjuntament amb altres disciplines i entitats precisament, cooperant - dins d'un pla de treball suficientment estudiat i sòlid per obtindre resultats satisfactoris.

Per a finalitzar aquest apartat i tenint en compte l'elevada quantitat d'informació que s'ha registrat com a conclusió de la investigació desenvolupada, s'inclou a continuació una taula-resum amb els blocs temàtiques i les conclusions que se n'extrauen:

Taula 20. Conclusions obtingudes

\begin{tabular}{cc}
\hline BLOC TEMÀTIC & CONCLUSIONS \\
\hline $\begin{array}{c}\text { LA SITUACIÓ DE } \\
\text { LES PERSONES } \\
\text { ANCIANES }\end{array}$ & $\begin{array}{c}\text { Es confirma una pèrdua cultural a la societat. } \\
\text { La relació de respecte i cura que antigament es tenia } \\
\text { amb els ancians, ha canviat. }\end{array}$ \\
& Com més joves són els participants, menys \\
\hline
\end{tabular}


coneixements culturals del país tenen.

Es discrimina els ancians de rendiments més baixos.

Hi ha una major discriminació a dones que a homes.

Tindria sentit desenvolupar projectes que tinguen l'objectiu de proposar els ancians com a font de saviesa insubstituïble i mereixedors de respecte i atenció.

S'identifica una relació entre la situació de les persones ancianes, del forro i de la pèrdua de tradicions.

PERCEPCIÓ DEL És una llengua adequada per als adults, però no per als FORRO xiquets.

Es considera que a l'escola hauria d'ensenyar-se forro.

No hi ha un rebuig visceral cap a la llengua. Els pares I'han abandonat en benefici del futur acadèmic dels fills.

L'escola seria clau per a fomentar el forro i els pares no rebutjarien aquesta idea.

Molts participants l'identifiquen com a llengua materna, encara que els hagen criat en portuguès.

Hi ha diglòssia entre el forro i el portuguès.

Hi ha joves interessats en el fet que el forro no es perda.

COOPERACIÓ LINGÜÍSTICA
És necessari formar en diversitat lingüística els cooperants.

Només les organitzacions més obertes a tipus de cooperació alternatius aplicarien iniciatives com la d'aquesta tesi. 
Cada projecte s'ha d'adaptar a les necessitats i condicions de cada zona o país.

ÚS DE TAV

Caldrà adaptar unes convencions de subtitulació específiques per a aquest país o per a països amb característiques semblants.

L'exposició a material en forro subtitulat tindria una bona acollida.

És necessari comprovar i actualitzar la situació dels estudiants amb discapacitat i de quina forma es diferencia dels que no en tenen.

La subtitulació podria ser útil per a l'alfabetització.

Seria positiu elaborar un equip mixt per tal que cada expert contribuïra al projecte amb els coneixements del seu àmbit.

La TAV haurà d'integrar-se en un programa més ampli planificat amb un objectiu concret.

El contingut dels vídeos ha de ser d'interès per a les persones a qui va dirigit i caldria decidir quin tipus de vídeo seria i la freqüència d'emissió o projecció.

Caldrà negociar amb els agents corresponents per tal que el projecte es puga desenvolupar.

Caldrà analitzar i esbrinar les possibilitats i la repercussió que tindria el fet d'utilitzar àudio estranger i subtítols en forro; realitzar un estudi específic sobre les possibilitats d'aplicar el doblatge en forro i sobre què suposaria en termes econòmics, de materials i de sostenibilitat realitzar tallers de doblatge.

Cal donar al forro un espai a les noves tecnologies. 


\subsection{PROPOSTA EN BASE ALS RESULTATS OBTINGUTS}

Després d'analitzar les conclusions que s'han extret dels resultats obtinguts, tant a les entrevistes realitzades a São Tomé com a les discussions i entrevistes amb els experts, es presenta una proposta de treball basada en els resultats que s'han exposat, així com una sèrie de possibilitats de treball que la complementen.

En l'apartat 2.4, es descriu breument l'estudi realitzat per Kruger et al. (2007) a Sud-àfrica, l'objectiu del qual era esbrinar si la subtitulació d'una llengua minoritzada contribuiria a la percepció del multilingüisme del país i contribuiria al desenvolupament de les llengües minoritàries, entre altres aspectes. Tenint aquest estudi com a exemple, es va plantejar un cas semblant però integrat dins el context d'un país diferent i de la cooperació. Els resultats obtinguts al llarg d'aquesta investigació ens porten a proposar una iniciativa més ferma per a la utilització de la subtitulació com a ferramenta de cooperació a São Tomé i Príncipe: la realització de vídeos subtitulats d'ancians dirigits a xiquets, que servirien per a fomentar l'aprenentatge de forro i transmetre la cultura ancestral a través de cançons o històries que podrien mostrar-se o bé a les escoles amb col-laboració governamental, o mitjançant un cinema itinerant al qual tinguera accés tota la comunitat, de manera semblant a les projeccions dels curtmetratges del projecte Aguêdê-Alê (Aguêdê-Alê, 2020) que es presenta en l'apartat 4.4. Aquests vídeos haurien de realitzar-se pensant en l'interès dels xiquets i les xiquetes, perquè gaudisquen de veure'ls, però també en l'objectiu de treballar en favor del rol social de les persones ancianes. Seria, per tant, un projecte basat en la justícia social d'aquestes persones (v. 4.2.3), ja que el que es pretén és millorar la seua qualitat de vida fomentant una convivència 
respectuosa i pacífica entre elles i la resta de la societat. Caldria cuidar especialment l'aspecte cultural dels vídeos, per tal d'assegurar un enfocament respectuós amb la cultura del país i basat en la cohesió social, pacífica i en la igualtat de condicions (Sánchez Rojo, 2010), més enllà del folklorisme (Carbonell, 2002). Aquesta proposta, a més a més, concorda i es podria integrar amb l'estratègia d'Escola e Identidade cultural Santomense (Ministério da Educação, Cultura e Formação, 2012) que s'entén com una forma de preservar la cultura del país a través de l'escola; i també amb el projecte Escola em Rede, que pretén fer arribar l'electricitat a totes les escoles del país i, per tant, permetria la projecció d'aquests vídeos (v. 5.3).

Aquesta proposta també compleix les recomanacions de la Declaració Universal de la Diversitat Cultural de la UNESCO, ja que fomenta la diversitat lingüística i l'aprenentatge de llengües des de la infantesa (en aquest cas, parlem del forro, però podria incorporar-se també la presència dels altres criolls del país), pretén preservar i utilitzar les mètodes de transmissió dels sabers que pertanyen a la cultura local (històries, cançons, etc.), i dona suport a l'expressió, la creació i la difusió lingüística (UNESCO, 2003, p. 3).

En cas que s'aplique aquesta iniciativa, seria convenient fer un seguiment del seu desenvolupament i resultats per esbrinar si ha resultat beneficiosa quant al foment del forro i també quant a la percepció de les persones ancianes, la qual cosa podria constituir un projecte de recerca futur derivat d'aquesta tesi.

Idealment, en la preparació i el desenvolupament d'aquest projecte participarien agents de diferents camps: TAV, $\mathrm{Cl}$, pedagogia 0 educació infantil 0 primària, aprenentatge de llengües, revitalització lingüística, etc. Fins i tot amb 
agents del món del cinema, ja que, com s'explica a l'apartat 4.4, també pot ser una ferramenta d'aprenentatge i sovint va de la mà de l'activisme per la capacitat que té per a generar consciència, com ja fan Tus Ojos (s/d) o CsA (s/d). La necessitat de formar un equip multidisciplinar com el que es proposa s'ha evidenciat amb les opinions dels experts i les expertes consultats en aquesta tesi: des de camp hi ha molt de desconeixement respecte als altres, com ara respecte a l'aprenentatge de llengües a partir de la subtitulació, el cost de la subtitulació, el percentatge d'alfabetització a São Tomé i Príncipe (v. 7.3.1), com funciona la cooperació lingüística (v. 7.3.1 i 7.3.2), etc. Aquesta tesi serviria com a base per a detectar aquestes llacunes i poder preparar el material de formació i discussió conjunta pertinents.

És probable que al principi es necessite l'ajut d'un equip extern que proporcione material de treball i formació a l'equip local però, perquè es puga garantir la sostenibilitat del projecte (v. 4.2.2), és imprescindible que es compte amb agents de São Tomé i Príncipe (ja siguen persones, administracions o organitzacions) que estiguen interessats en la promoció de forro i la sensibilització sobre les persones ancianes, i que estiguen disposats a encarregar-se del seguiment del projecte una vegada disposen de la capacitat tècnica i de gestió per a mantenir-lo. Com s'ha explicat al capítol 2 amb el cas dels fansub, és possible realitzar uns subtítols correctes encara que les persones que se'n encarreguen no tinguen molta formació. Una part de l'ajut extern que es menciona a l'inici del paràgraf, podria consistir a ensenyar les nocions bàsiques d'un programa de subtitulació de lliure accés per tal que després es puga continuar la tasca de manera independent.

Cal destacar les fases de l'ED que s'acomplirien en aquesta proposta (v. 4.2.1.1): la sensibilització d'aquelles persones que vegen el vídeo; la incidència de les 
administracions, que com a mínim haurien d'autoritzar la iniciativa; la mobilització d'aquelles persones locals que ja estan sensibilitzades i tenen interès a participar d'alguna manera en aquest projecte; i la investigació, que suposaria fer un seguiment per a analitzar els resultats. En definitiva, es tracta d'una proposta emmarcada en el foment de la capacitat d'Alonso i Glennie (2015) (v. 4.2.1), que significaria donar suport en termes de formació, recursos organitzatius i humans, etc. amb l'objectiu d'afavorir l'autonomia i la capacitat del país.

\subsection{CONSECUCIÓ D'OBJECTIUS I VALIDACIÓ D'HIPÒTESIS}

\subsubsection{Consecució d'objectius}

Les conclusions exposades anteriorment han pogut recollir-se a través dels esforços dirigits a assolir tant l'objectiu principal com els objectius secundaris que s'havien proposat a l'inici de la investigació. En aquest apartat es pot trobar de quina manera s'ha aconseguit arribar a cadascun d'aquests objectius.

En primer Iloc, s'analitza l'acompliment dels objectius secundaris, ja que gràcies a la consecució d'aquests ha sigut possible arribar a l'objectiu principal. En segon lloc, per tant, es tracta l'acompliment de l'objectiu principal, que ha servit de base per a desenvolupar aquesta tesi.

Objectiu secundari 1. Esbrinar la percepció cultural i lingüística d'un grup d'ancians parlants de forro

Aquest objectiu secundari s'ha assolit de quatre maneres fonamentals. En primer lloc, mitjançant la bibliografia 
consultada sobre història, cultura i llengües de São Tomé i Príncipe (v. 5), que ha proporcionat una font d'idees per extraure opinions rellevants a les entrevistes $i$, sobretot, per poder comprendre els entrevistats i el seu bagatge cultural. En segon lloc, mitjançant la bibliografia de caràcter etnogràfic ( $(v .3)$, que ha permés una planificació minuciosa de les entrevistes en fases per a obtindre uns resultats més precisos en relació amb la temàtica de la tesi i per a saber reaccionar quan l'estructura preparada no funcionava (v. 6). En tercer lloc, mitjançant la bibliografia facilitada per l'ONG Cooperación Bierzo Sur, entre altres d'accés lliure, sobre projectes de cooperació i dades oficials sobre les persones ancianes de São Tomé i Príncipe (v. 5.4.1). En quart lloc, mitjançant les entrevistes amb les persones ancianes, que són la font primària d'aquesta investigació de camp (v. 6.2.1.1 i 7.1).

Com a resultat de l'assoliment d'aquest objectiu secundari, ha sigut possible arribar a quatre conclusions, que s'han vist reforçades per l'opinió d'altres entrevistats:

1. La concepció del forro com una llengua adequada per als adults, però incorrecta per als xiquets (v. 7.2.2).

2. La consideració que hauria d'ensenyar-se forro a l'escola (v. 7.2.2).

3. $\quad \mathrm{Hi}$ ha una pèrdua de coneixements $\mathrm{i}$ pràctiques culturals a la societat (v. 7.2.1).

4. La relació que es tenia amb les persones ancianes, ha canviat (v. 7.2.1). 
Objectiu secundari 2. Analitzar les reflexions i les opinions de persones no ancianes residents a São Tomé sobre els comentaris dels ancians respecte a la situació que viuen, l'ús de la llengua i els trets culturals del país.

De nou, la bibliografia referent a la cultura i la història de São Tomé i Príncipe i el forro i a la situació de les persones ancianes ha sigut essencial per concretar les preguntes que caldria realitzar al terreny i poder comprendre les respostes pels seus matisos culturals. La bibliografia referent a la realització d'entrevistes per a la investigació ha sigut important per aconseguir respostes sinceres i rellevants per al projecte. Les transcripcions de totes les entrevistes i grups de discussió s'han analitzat segons una sèrie de temàtiques que es repetien al llarg dels discursos per a facilitar les comparacions de les diverses respostes dels participants.

Les notes de camp també han sigut de gran importància, ja que les reflexions dels participants sobre els temes que es proposaven sovint esdevenien en moments inesperats, quan no es tenia càmera ni gravadora a l'abast per poder enregistrar-les. D'aquesta manera, també es pot tindre constància d'algunes aportacions rellevants per a la investigació que haurien quedat oblidades si no s'hagueren tingut en compte (v. 6.3.3).

Per últim, l'adaptació dels paràmetres de la subtitulació ha sigut de gran utilitat per assegurar la correcta assimilació dels subtítols per part de tots els participants, independentment del seu nivell de lectura, i el suport d'Alda en aquest sentit (v. 6.5) ha resultat clau.

Pel que fa a les conclusions corresponents a aquests objectiu secundaris, s'observa: 
1. Que els participants de São Tomé i Príncipe identifiquen una pèrdua cultural a la societat (v. 7.2.1, 7.2.2, 7.2.3, 7.2.4).

2. Els participants no ancians corroboren que la relació que antigament es tenia amb els ancians ha canviat (v. 7.2.2).

3. S'identifica una major discriminació envers els ancians més empobrits, i també que les dones pateixen més discriminacions que els homes (v. 7.2.3).

4. Tots els participants troben una relació entre la situació de les persones ancianes, l'ús del forro i la pèrdua de tradicions del país (v. 7.2.1, 7.2.2, 7.2.3, 7.2.4).

Objectiu secundari 3. Esbrinar la percepció que tenen de la subtitulació les persones participants de São Tomé i Príncipe.

A través de l'exposició al vídeo subtitulat dels ancians i les preguntes específiques sobre aquesta qüestió a les entrevistes, ha sigut possible esbrinar l'acceptació de la subtitulació entre els participants no ancians amb resultats positius. Els entrevistats i les entrevistades de São Tomé, la majoria sense hàbit de lectura i que no estan acostumades a llegir subtítols, abracen de bon grat aquesta modalitat de TAV. Sorprén aquesta acceptació si es compara amb l'Estat espanyol, on sí que sol crearse un cert debat entre persones que prefereixen la versió original subtitulada i els que se senten més còmodes amb la versió doblada.

Els participants de São Tomé no només diuen sentir-se còmodes amb els subtítols, sinó que tots ells 
asseguren que veurien més programació en forro subtitulada i en troben beneficis quant a l'aprenentatge de la llengua, per exemple. Fins i tot hi va haver una proposta que planteja l'emissió d'un programa infantil en forro subtitulat per acostar la llengua als més menuts.

Aquest escenari, encara que la quantitat i distribució de participants no és representativa de la població total del país, resulta encoratjador per a plantejar projectes fent ús de la subtitulació donada l'acceptació unànime que ha rebut en aquest cas. Cal recordar, però, que la subtitulació per als participants de São Tomé es va adaptar al nivell de lectura estimat que podien tindre i aquest factor hauria de tindre's en compte en futurs treballs, com ja s'ha dit.

D'aquest objectiu secundari s'extrauen dues

conclusions:

1. La necessitat d'adaptar unes convencions de subtitulació específiques per a São Tomé i Príncipe o per a altres països amb característiques semblants, encara que s'allunyen de les tradicionalment establertes $\mathrm{i}$ tinguen com a resultat uns subtítols desiguals, més breus o menys estètics (v. 7.2.3 i 7.3.2).

2. L'exposició a material en forro subtitulat tindria una bona acollida per part de la població, ja que, sense tindre coneixements acadèmics, intueixen que és una eina útil per a l'aprenentatge i la visibilitat d'una llengua (v. 7.2). 
Objectiu secundari 4. Analitzar la reacció de diferents agents relacionats amb la cooperació i amb la Traducció Audiovisual envers la subtitulació com a eina de $\mathrm{Cl}$ dins el context de São Tomé i Príncipe.

Aquest objectiu secundari s'ha assolit a través de la realització de grups de discussió (amb experts en $\mathrm{Cl}$ i TAV) i entrevistes (amb els experts en cooperació lingüística), per als quals s'ha consultat bibliografia específica sobre cooperació i etnografia amb la intenció d'estructurar per fases cada aspecte d'aquesta consulta a experts. Les conclusions a les quals ha sigut possible arribar a partir d'aquest objectiu secundari són:

1. Segons la valoració de l'ítem corresponent, els experts troben que la cooperació lingüística seria útil al cas particular de São Tomé i Príncipe.

2. És possible utilitzar la subtitulació com a ferramenta per a l'alfabetització.

3. Seria positiu elaborar un equip mixt per tal que cada expert contribuïra al projecte amb els coneixements del seu àmbit, o utilitzar la metodologia dels grups de discussió a l'hora de preparar la planificació del projecte de cooperació.

4. La utilització de la TAV en un projecte de cooperació ha d'integrar-se dins d'un programa planificat amb un objectiu concret per tal d'obtenir resultats positius.

5. S'ha de seleccionar el contingut dels vídeos que es mostre per tal que siguen d'interès per a les persones a qui va dirigit. 
6. Cal planificar el visionat dels vídeos tenint en compte el to (humorístic, infantil, educatiu, musical, etc.), la freqüència d'emissió per tal que l'activitat siga efectiva, les negociacions amb diferents agents per poder comptar amb la seua col-laboració (professorat, Ministeri d'Educació, etc.), i el públic a qui va dirigit (infantil, adolescent, familiar, etc.). Si es planteja com una projecció itinerant a les escoles o a les comunitats, també caldria arribar a acords quant a un calendari per saber quan es projecta i on, i assegurar el transport per fer arribar la projecció a les diferents comunitats o escoles.

7. Caldria fer un estudi que permeta establir unes convencions de subtitulació específiques per a São Tomé i Príncipe.

8. Cal analitzar $\mathrm{i}$ esbrinar les possibilitats $\mathrm{i}$ la repercussió que tindria a São Tomé la modalitat d'àudio en una llengua estrangera i subtítols en forro.

9. Podrien estudiar-se les possibilitats econòmiques, de materials i de sostenibilitat que tindria realitzar tallers de doblatge on les persones ancianes participen com a actors i actrius.

10. Caldria realitzar un estudi específic per tindre una premissa més sòlida sobre les possibilitats, l'acollida i els possibles resultats d'aplicar el doblatge com a ferramenta per rehabilitar llengües quan no hi ha alfabetització.

11. S'ha de donar al forro un espai a les noves tecnologies i un paper al món digital actual per tal que la seua revitalització tinga èxit, com indiquen els experts en cooperació lingüística. 
A continuació, cal centrar-se en l'objectiu principal d'aquesta tesi, valorar si la subtitulació de vídeos podria utilitzar-se com a eina de cooperació activa per a la integració d'ancians o per a programes de revitalització lingüística, que s'ha pogut assolir gràcies a la consecució dels objectius secundaris esmentats anteriorment. Més concretament, les conclusions que validen l'objectiu principal són:

1. Els espectadors de São Tomé i Príncipe acceptarien la subtitulació.

2. Les dades contextuals indiquen un nivell acceptable d'alfabetització.

3. Els experts en TAV i cooperació lingüística coincideixen en el fet que la subtitulació seria una ferramenta econòmica per a una ONG.

4. Els participants no ancians de São Tomé i Príncipe i els participants experts en cooperació lingüística troben que la situació de la llengua i la situació de les persones ancianes estan relacionades $\mathrm{i}$, per tant, la subtitulació seria útil per a conscienciar envers les dues.

5. Els participants no ancians de São Tomé reclamen una forma lúdica d'aprendre forro i la subtitulació podria ser una manera divertida d'aprenentatge.

6. La subtitulació permetria incloure el forro a la nova era digital, en cas que els vídeos estiguen disponibles en una plataforma a la qual es puga accedir amb el telèfon mòbil, a través d'una xarxa social, etc. 


\subsubsection{Validació d'hipòtesis}

La idea inicial de la qual va sorgir aquesta tesi era que la subtitulació pot ser una ferramenta útil en treballs de cooperació en favor de les persones ancianes i del crioll forro en São Tomé i Príncipe. Aquesta premissa va ser la base per formular tres hipòtesis la validació de les quals es presenta en aquest apartat després d'estudiar els resultats obtinguts:

1. Que la presentació de temes sensibles a São Tomé i Príncipe, com l'abandonament d'ancians o el risc d'extinció del forro a través d'un mitjà audiovisual, no generaria rebuig a les persones entrevistades.

Després d'estudiar els resultats obtinguts (v. 7), la primera hipòtesi es consolida com a vàlida. Cap dels 16 entrevistats va mostrar rebuig al contingut del vídeo ni a cap dels temes pels quals se'ls preguntava. Una mostra d'aquesta hipòtesi és que, com es pot comprovar en l'apartat 7.2, tots ells van declarar que els agradaria que hi haguera disponible més programació subtitulada que els permetera aprendre o perfeccionar forro i aprendre més sobre la seua cultura. Tots es van mostrar sensibles a la marginació $i$ estigmatització dels ancians i van proposar en major o menor grau, mesures que consideren que podrien prendre's per revertir aquesta situació.

2. Que la subtitulació al portuguès de les entrevistes als ancians en forro serviria perquè els entrevistats reflexionen sobre els aspectes que es plantegen: la llengua, les tradicions i la situació de les persones ancianes.

Pel que fa a la segona hipòtesi, cal destacar la facilitat dels entrevistats i les entrevistades per parlar dels temes que apareixien al vídeo després d'haver-lo vist. També hi va haver 
alguns casos de reflexions posteriors al vídeo i les entrevistes, concretament per part d'Alice, que va reflexionar sobre si sentia que coneixia bé la cultura del país o no, i va considerar que no perquè no sabia forro; d'Amélia, que va estar pensant sobre els escassos coneixements culturals del país que havia transmès als seus fills; Matilde, que va adonar-se que les dones eren més acusades de fetilleria que els homes; i Alda, que va tindre la idea que un programa infantil en forro subtitulat podria ajudar els xiquets a iniciarse en la llengua. Amb tots aquests exemples queda validada la segona hipòtesi, ja que, efectivament, el vídeo subtitulat va fer que els participants no ancians reflexionaren sobre els temes proposats.

3. Que la subtitulació podria utilitzar-se com a ferramenta de $\mathrm{Cl}$ per a treballar en favor de la revitalització del forro i la sensibilització envers les persones ancians de manera transversal, $i$ els experts consultats apreciarien la possibilitat d'emprar una nova eina (la subtitulació) en contextos de $\mathrm{Cl}$.

La tercera hipòtesi, que s'ha anat desgranant al llarg d'aquest capítol i el precedent, es confirma segons l'opinió dels experts consultats, que destaquen que l'ús de la subtitulació aplicada al cas de São Tomé i Príncipe que presenta aquesta tesi, suposaria un estímul de l'autoestima de les persones ancianes, les acostaria a elles $i$ al crioll forro al públic, contribuiria a l'aprenentatge de forro i, a més a més, es tractaria d'una eina econòmica per a utilitzar en $\mathrm{Cl}$.

D'acord amb els resultats obtinguts de les respostes i les opinions de tots els participants a través de la metodologia emprada, la subtitulació sí que podria ser una ferramenta activa de cooperació per treballar en favor de la sensibilització envers les persones ancianes de São Tomé i Príncipe a través de la revitalització del forro de la manera que proposa 
aquesta tesi: realitzar vídeos subtitulats d'ancians dirigits a xiquets, que servisquen per a fomentar l'aprenentatge de forro i per a transmetre la cultura ancestral a través de cançons 0 històries (v. 8.2). Aquesta proposta es basa en moltes de les opinions de les persones entrevistades a São Tomé i de les expertes i els experts consultats. Per exemple, l'opinió d'Amélia sobre per què les persones ancianes pateixen de certa marginació a la societat de São Tomé i Príncipe justifica la planificació d'un projecte en el qual es relacionen d'alguna manera les persones ancianes amb persones més joves i que pose a les primeres en valor. Segons aquesta entrevistada, les persones ancianes ja no cuiden els nets ni els conten històries, i açò no només contribueix a l'abandonament dels ancians per part dels seus familiars, sinó que també allunya els joves de la cultura del seu país per no haver tingut el contacte amb algú que els l'explique (v. 7.2.4).

A més, tots els entrevistats de São Tomé expressen que els agradaria que la llengua s'estudiara a les escoles i que tinguera més presència als mitjans de comunicació (v. 7.2). Aquesta voluntat suposa una base molt positiva per a desenvolupar un projecte com el que es proposa, ja que ofereix la premissa d'una bona acollida per part de la població.

Un expert en $\mathrm{Cl}$ (v. 7.3.1) proposa organitzar concursos de poesia, recopilacions de refranys i contes, que els ancians ho expliquen als xiquets, etc. i aprecia la subtitulació com una forma mitjançant la qual les persones ancianes recuperarien la seua autoestima per sentir-se part important d'un projecte. Aquesta contribució reforça la idea d'utilitzar vídeos subtitulats d'ancians, activitat que també permetria treballar per a evitar la desaparició del forro i dels aspectes culturals que formarien part del contingut del vídeo, segons es proposa al present treball (v. 8.2). Aquest últim aspecte és important, ja que tots els participants troben una relació 
entre la situació de les persones ancianes, l'ús del forro i la pèrdua de tradicions del país (v. 7.2.) i la proposta d'aquesta tesi permet abraçar les tres qüestions alhora.

També s'ha vist com alguns entrevistats de São Tomé identifiquen el forro com una llengua per a cantar i fer bromes (v. 7.2.2 i 7.2.4) i d'altres pensen que, si s'integra a l'escola, hauria de fer-se d'una forma diferent i divertida (v. 7.2.2, 7.2.4). De nou, aquestes opinions encoratgen la proposta d'aquesta tesi, ja que aquests vídeos podrien també mostrar-se a les escoles, fins i tot com a suport didàctic, com assenyala un expert en cooperació lingüística (v. 7.3.3).

A banda, tots els experts en TAV pensen que aquesta modalitat de traducció podria contribuir que hi haguera un canvi de percepció envers el forro, a més de ser una forma divertida de facilitar que els xiquets aprenguen la llengua (v. 7.3.2). Cal recordar que una de les entrevistades de São Tomé (v. 7.1.1) proposa la realització d'un programa infantil per a iniciar els xiquets en l'aprenentatge de forro, idea que s'ha incorporat a la proposta de l'apartat 8.2.

Els experts en TAV van més enllà i proposen un programa en el qual es visiten ancians de diferents parts del país i que siguen ells els que expliquen en forro característiques culturals d'eixa zona (gastronomia, música, etc.); un programa en forro de jocs o cançons tradicionals dirigit a xiquets i presentat per ancians; $i$ també la possibilitat de fer un cinema itinerant (v. 7.3.2). Com es pot veure, aquestes propostes encaixen amb la que presenta aquesta investigació i caldria explorar-les per a poder perfilar un pla d'acció més complet i efectiu. 


\subsection{FUTURES LÍNIES DE RECERCA}

La revisió de les conclusions dels resultats obtinguts i de la consecució d'objectius, així com les idees expressades pels mateixos participants que s'ha fet als apartats anteriors d'aquest capítol condueix inevitablement a plantejar possibles temes d'investigació futurs que permeten donar una continuació a la recerca sobre la inclusió de la TAV en projectes de $\mathrm{Cl}$ a São Tomé i Príncipe de la manera que es proposa en aquesta tesi, o en altres contextos i països. Totes aquestes línies d'investigació suposen una acció al terreny, per la qual cosa impliquen connotacions de la recerca etnogràfica (v. 3.2), com s'explica en cada cas.

En primer lloc, per tal de tindre una idea clara de les zones del país més afectades i en les quals caldria prioritzar els treballs, seria necessària una anàlisi quantitativa a cada districte del país que revele informació sobre quants ancians en risc d'exclusió hi ha i de quina manera els percep el veïnat. Aquest exercici suposa realitzar un treball de camp, que implicaria una planimetria prèvia per a organitzar la temporització i el desenvolupament de la tasca per zones, consultes amb la població per a identificar aquestes persones ancianes, notes de camp i una entrevista estructurada amb els ancians per tal de corroborar si es troben en situació d'exclusió. Amb aquesta informació, amb la qual es podria col-laborar amb l'Institut Nacional d'Estadística de São Tomé i Príncipe, podrien crear-se unes directrius clares i directes per desenvolupar les activitats de sensibilització d'ancians de la manera que es proposa en aquesta tesi o en qualsevol altre projecte que tinga el mateix objectiu. Així mateix, mitjançant les entrevistes podria conéixer-se quina és la llengua d'aquests ancians per valorar si, efectivament, es desenvolupen activitats a través del foment del forro 
o si, segons la zona, també resulta adient incloure l'angolar, per exemple, si aquesta és la llengua que parla un grup considerable de persones ancianes en exclusió.

En relació amb el que comenta Ruth sobre l'analfabetisme a São Tomé i Príncipe en comparació amb les dades oficials (v. 7.3.1), seria convenient realitzar un estudi independent per esbrinar quin és el grau actual d'alfabetització, especificant l'edat i les condicions físiques i psíquiques dels enquestats, la qual cosa implicaria els mateixos elements etnogràfics que el cas anterior (planimetria, entrevistes i notes de camp). Si escau, també caldria ampliar les investigacions existents sobre l'ús dels subtítols intralingüístics per a millorar l'alfabetització (Gernsbacher, 2015; PlanetRead, 2018a; PlanetRead, 2018b) per a esbrinar com es podria aplicar a la realitat de São Tomé i Príncipe d'acord amb les dades sobre la població analfabeta que s'hi hagen extret anteriorment. D'eixa manera, es podria valorar quin efecte tindria sobre el nivell d'alfabetització d'aquestes persones l'exposició a subtítols interlingüístics, com proposa aquesta tesi. Aquesta prova es podria realitzar, de nou, durant una estada al terreny per a desenvolupar un projecte pilot que servira per avaluar la utilitat de la subtitulació en l'alfabetització a São Tomé i Príncipe.

Al grup d'experts en $\mathrm{Cl}$ es va llançar la idea d'organitzar concursos de poesia, cançons, conta-contes, etc. en forro amb les persones ancianes com a protagonistes. Caldria dissenyar amb profunditat aquesta proposta i decidir amb agents locals que estiguen sensibilitzats amb la situació del forro i la dels ancians quin serà el paper exacte de les persones ancianes: els jutges que decideixen el guanyador, els participants o una barreja d'aquestes dues opcions, si es televisarà, etc. Sense dubte, és una bona oportunitat per començar a treballar per recuperar el rol d'explicar històries que tenien els ancians a les famílies, segons 
explica Amélia (v. 7.2.4). Aquesta idea, una vegada estiga completament perfilada, podria desenvolupar-se sense massa dificultat en una zona concreta i analitzar els resultats per valorar les possibilitats d'extrapolar-la a altres districtes i fins i tot implicar les xarxes socials, com recomanen els experts en cooperació lingüística. A més, podria ser material de gravació per a possibles vídeos subtitulats. Seria interessant fer un seguiment des del moment en què s'anuncia aquesta activitat per saber quina és l'acollida de la població, l'interès per participar, l'assistència i la valoració final de la comunitat i dels beneficiaris perquè servisca com a base per a futurs projectes similars. En aquest cas, la proposta implicaria, a més del treball de camp, la planimetria i les notes de camp, l'observació participant per a redactar l'informe de la forma més objectiva possible o, fins i tot, un diari de camp on es reflecte l'evolució del projecte, que es podria concebre com un projecte d'investigacióacció.

Una altra idea, en aquest cas sorgida del grup d'experts de TAV, és la d'un cinema itinerant. Per a portar-la a terme, caldria arribar a un acord amb el Ministeri corresponent perquè permeta la projecció i s'acorde de quina manera s'organitzaria el transport i la itinerància de l'activitat (és a dir, treball de camp i planimetria). A més, hauria de concretar-se si les projeccions són de material estranger doblat 0 subtitulat $O$ de material gravat a São Tomé i Príncipe. Al primer cas, també caldria estudiar de quina manera implementar la sensibilització cap als ancians: un anunci, un curtmetratge previ a la pel-lícula, dins la projecció principal, etc. En qualsevol cas, seria necessari establir quina modalitat de TAV seria la més adient i inclusiva (encara que no es comenta al grup d'experts, també existeix la possibilitat d'utilitzar la subtitulació per a persones sordes i implicar així la població sorda del país), i quina llengua s'utilitzaria per a subtitular o doblar. 
Generalment, els experts consultats solien pensar en la televisió com a mitjà per difondre el material subtitulat. En aquest sentit, és necessari investigar al terreny quina és la incidència real de la televisió al país i quina influència té a la població, estudiar les possibilitats de negociar amb la TVS l'emissió d'un programa infantil subtitulat o doblat en forro o un programa de tipus cultural, on siguen les persones ancianes les que porten el pes del contingut de la manera que proposa Marina al grup d'experts en TAV, proposant una versió del programa d'À Punt Bambant per casa, on es visiten diferents districtes de la mà de persones locals per divulgar el seu patrimoni cultural, gastronòmic, musical, etc. La proposta de Marina, que suposaria una planimetria i treball de camp, situa a les persones ancianes com les encarregades de presentar aquest patrimoni als conductors del programa i al públic que el veurà (v. 7.3.2).

Un altre aspecte sobre el qual incideixen els experts, és en la necessitat d'implicar les escoles en la revitalització del forro perquè no es perda. Els entrevistats de São Tomé i Príncipe i els dels experts en cooperació lingüística proposen que aquesta implicació no fora en forma d'una assignatura a l'ús, sinó que es tractara d'un ensenyament diferent i que resultara divertit. En aquest cas, convindria comptar amb l'ajut de pedagogs $\mathrm{i}$ experts en ensenyament de llengües minoritàries, plurilingüisme, etc. i, sobretot, amb els mestres i els experts en forro de São Tomé que estan interessats a introduir la llengua a l'escola. Amb la col-laboració i el vistiplau del Ministeri d'Educació, caldria elaborar una metodologia, un temari i uns materials didàctics específics per al forro de la forma amena i diferenciada d'altres assignatures que es reclama. Un cop s'haja aconseguit aquest acord i comence a aplicar-se en algun centre de forma experimental, convindria fer un seguiment del desenvolupament i l'acollida del projecte mitjançant l'observació participant per corregir a temps les possibles errades 0 els 
inconvenients que sorgisquen, la qual cosa faria d'aquest projecte, com ja s'ha dit, un projecte d'investigació-acció. L'informe de seguiment del projecte permetria perfeccionar aquest pla d'ensenyament, que seria únic i endèmic de São Tomé i Príncipe i podria ser un exemple per a altres països en situacions similars.

Pel que fa a l'àmbit de la traducció, com ja s'ha indicat, queden molts aspectes per investigar. Primerament, seria necessari establir unes convencions de subtitulació per a São Tomé i Príncipe en cas de fer-se'n ús. Aquestes convencions haurien de seguir uns criteris únics, bastant-se en la velocitat de lectura i la comprensió lectora de la població, per a la qual cosa és necessari desenvolupar una investigació específica al terreny amb una planimetria adequada que permeta testar aquestes destreses en una quantitat representativa de persones de tot el país. En segon lloc, podria investigar-se quines possibilitats tindria que els subtítols foren en forro, com proposa un dels experts en cooperació lingüística, amb tècniques semblants amb les que s'han seguit en aquesta tesi. A més, la subtitulació per a sords com a eina d'integració de persones sordes seria un altre camp d'investigació, al qual es podria col-laborar amb les associacions locals que treballen amb les persones sordes al país.

Així i tot, quedarien moltes branques de la TAV que es podrien investigar en São Tomé i Príncipe com, per exemple, les possibilitats del doblatge que, encara que no es va contemplar a l'inici d'aquest treball, també podria ser un aspecte més per a investigar i, des del punt de vista d'aquesta tesi, podrien realitzar-se tallers com es proposa al grup d'experts en TAV, als quals les persones ancianes puguen participar com a actors de doblatge; fins i tot podria valorar-se que també hi participaren xiquets i joves com a projecte intergeneracional. En cas que la TAV tinga una bona acollida al país i s'enregistren progressos positius, també 
podrien organitzar-se cursos sobre doblatge i subtitulació per a formar les persones interessades del país i que aquestes activitats puguen estar en mans de persones locals i tinguen l'autonomia de prosseguir sense dependència d'organismes o ONG estrangers. L'existència del fansub, que s'explica al capítol 2, és una bona mostra que és possible realitzar subtítols sense necessitat de tindre una titulació superior en aquesta matèria.

Seria interessant conéixer altres investigacions sobre l'aplicació de la TAV en projectes de $\mathrm{Cl}$, revitalització lingüística o alfabetització en altres països que tinguen un grup de persones en risc d'exclusió i parlants d'una llengua minoritzada, per a aprendre d'eixa experiència prèvia i avaluar quins aspectes es podrien aplicar al cas de São Tomé i Príncipe, utilitzarlos com a base de treball i poder fer comparatives dels resultats per a extraure conclusions més globals.

Per últim, una altra observació dels experts en cooperació lingüística que cal tindre en compte és la necessitat d'incloure en la revitalització del forro de quina manera s'aplicaria hui dia amb els reptes tecnològics i digitals que existeixen, perquè aquesta llengua no es quede enrere. Es tractaria, per tant, d'investigar amb agents locals de quina forma incloure el forro en aquest nou paradigma, per assegurar que, en la pràctica, siga una llengua que es puga utilitzar en qualsevol àmbit.

Amb aquest paràgraf conclou l'aportació d'idees de recerca futures sobre la TAV en l'aprenentatge o la normalització del forro i la integració de les persones ancianes de São Tomé i Príncipe. La TAV suposa una ferramenta nova a la $\mathrm{Cl}$ i ofereix nombroses possibilitats, ja que permet treballar diferents aspectes de manera transversal i és adient per adaptar-se a l'època tecnològica en què vivim. Les dades, les opinions i els testimonis 
que es recullen a la present tesi són el motor que impulsa aquesta visió positiva sobre les possibilitats de la TAV en el marc de la cooperació i el desenvolupament, i reforça el convenciment que des de qualsevol àmbit de coneixement es pot contribuir a millorar algun aspecte de la societat. 


\section{BIBLIOGRAFIA}

Abarrategi Garaigordobil, Txema. (2016). Un acercamiento a la identidad de cooperación. La cooperación lingüística como clave para la soberanía cultural. Revista Pueblos, 70. http://www.revistapueblos.org/blog/2016/07/28/unacercamiento-a-la-identidad-de-la-cooperacion-lacooperacion-linguistica-como-clave-para-la-soberania-cultural/

Abramac, Gabi. (2015). Muerte y revitalización de la lengua hebrea. Ix Conferencia Internacional Lingüística. Instituto de Literatura y Lingüística José Antonio Portuondo Valdor. La Habana, Cuba.https://www.academia.edu/18654161/Muerte_y_revitaliz aci\%C3\%B3n_de_la_lengua_hebrea

Abreu de Castaño, Inês Filipa. (2012). A Cultura Santomense: identidade cultural e Santomensidade, pp. 53-65. São Tomé e Príncipe: Cultura(s)/ Património(s)/ Museu(s), VOLUME I. Faculdade Ciências Sociais e Humanas, Universidade Nova de Lisboa.

ACTUAR (2012). Movilización Social para la Seguridad Alimentaria y Nutricional: la experiencia de trabajo en múltiples redes temáticas de la REDSAN-Palop, pp. 17-20. Coimbra: ACTUAR / REDSAN-PALOP

AECID. (2016). Sesión de Cine, Desarrollo y Sostenibilidad. La Cooperación Española en el Festival de San Sebastián. Recuperat el 29 de juny de 2020 de http://www.aecid.es/ES/Paginas/Sala\%20de\%20Prensa/Agen da/2016/2016_09/15_sanse.aspx 
AFDB. (2016). African Development Bank Group. Recuperat el 29 de juny de 2020 de https://www.afdb.org/en/countries/southernafrica/sao-tome-and-principe

Agostinho, Ana Lívia. (2015). Fonologia e método pedagógico do lung'le. Tese (Doutorado em Filologia e Língua Portuguesa) Faculdade de Filosofia, Letras e Ciências Humanas, Universidade de São Paulo, São Paulo.

Agostinho, Ana Lívia i Bandeira, Manuele. (2017). Línguas nacionais de São Tomé e Príncipe e ortografia unificada, pp. 209-229. RILP - Revista Internacional em Língua Portuguesa, 31.

Aguêdê-Alê. (2020). Aguêdê-Alê. Recuperat el 24 d'agost de 2020 de https://www.aguede-ale.com/index.php\#!

Alibbi, Andrew. (2014). Subtitling in the Nigerian Film Industry. Informative or Misleading?, pp. 48-61. CINEJ. Cinema Journal, 4(1).

Alidou, Hassana. (2009). Promoting Multilingual and Multicultural Education in Francophone Africa: challenges and perspectives, pp. 105-129. Languages and Education in Africa: a comparative and transdisciplinary analysis. Ed. Birgit Brock-Utne i Ingse Skattum. Bristol Papers in Education: comparative and international studies.

Almada Negreiros, José. (1895). História Ethnographica da llha de S. Thomé. Lisboa: Antiga Casa Bertrand - José Bastos.

de Almeida, Mauro W. B. (2004). A etnografia em tempos de guerra. Contextos temporais e nacionais do objeto da antropologia, pp. 61-81. Antropologias, Histórias e Experiências. Eds. 
Fernanda Arêas Peixoto, Heloisa Pontes, Lilia Moritz Schwarcz. UFMG.

Alonso, José Antonio i Glennie, Jonathan. (2015). ¿Qué es la cooperación para el desarrollo?. Informes de política para el Foro sobre Cooperación para el Desarrollo de 2016, 1. ECOSOC. Development Cooperation Forum.

Álvarez Álvarez, Carmen. (2008). La etnografía como modelo de investigación en la educación. Gazeta de Antropología, 24 (1). https://www.ugr.es/ pwlac/G24_10Carmen_Alvarez_Alvarez.h tml

Álvarez Vilas, Carmen. (2015). Cicatrices en el alma. A propósito de un caso... en Santo Tomé y Príncipe, pp. 25-42. Sanitat a l'Àfrica. Barcelona, Drassanes per Àfrica.

Andriesen, Simon. (2015). Translation in Africa. TAUS Review. Recuperat el 29 de juny de 2020 de https://www.taus.net/think-tank/articles/translation-in-africa

Andronis, María Antonia. (2004). Iconization, Fractal Recursivity, and Erasure: Linguistic Ideologies and Standarization in QuichuaSpeaking Ecuador, pp. 236-269. Proceedings of the Eleventh Annual Symposium about Language and Society, Austin. Texas Linguistic Forum, 47.

Appel, René i Verhoeven, Ludo. (1995). Decolonization, language planning and education pp. 65-74. Pidgins and Creoles. An introduction. Ed. Jacques Arends, Pieter Muysken and Norval Smith. John Benjamin Publishing Company.

de Araujo, Gabriel. (2010). Relações entre as fonologias das línguas crioulas de STP e a proposta ortográfica ALUSTP. 7 
Congresso Ibérico de Estudos Africanos, Lisboa. Anais do 7 Congresso Ibérico de Estudos Africanos. ISCTE.

de Araujo, Gabriel i Agostinho, Ana Lívia. (2010) Padronização das línguas nacionais de São Tomé e Príncipe. Língua e Instrumentos Linguísticos, pp. 49-81. Revista Língua e Instrumentos Lingüísticos, 26.

de Araujo, Gabriel i Hagemeijer, Tjerk. (2013). Dicionário livre do santome-português. São Paulo: Hedra.

Arends, Jacques. (1995). The socio-historical background of creoles, pp. 15-25. Pidgins and Creoles. An introduction. Ed. Jacques Arends, Pieter Muysken and Norval Smith. John Benjamin Publishing Company.

Ascencio, Milton. (2009). La pérdida de una lengua: el caso del náhuat, pp. 68-78. Teoría y Práxis, 14. redicces.org.sv/jspui/bistream/10972/920/1/nahuat.pdf

Ayan, Erdal. (2015). Minority language loss: socio-cultural and linguistic causes, pp. 62-88. European Journal of English Language, Linguistics and Literature. 2(1). http://www.idpublications.org/ejelll-vol-2-no-1-2015/

Ayonghe Lum, Suzanne i Tiokou, Carlos. (2015). Analysis of the prospects and challenges of subtitling as a mode of audiovisual translation in Cameroon, pp. 61-70. Journal of Languages and Culture, 6(7).

Ayonghe Lum, Suzanne i Ntowa Tchuingoua Rachelle Nely. (2015). Audiovisual Translation as a tool for teaching English Language to French-speaking students in Cameroon, pp. 200206. Journal of African Studies and Development, 7(8). 
Ayora Esteban, M. Carmen. (2010). Diversidad lingüística y cultural en un ámbito educativo de lenguas en contacto, pp. 30-52. Pragmalingüística, 18.

Ayres, Jennifer. (2003). "In the middle": Language Attitudes and Identity among Bilingual Hispanic-American College Students, pp. 47-60. Céfiro: enlace hispano cultural y literario, 4(1). Texas Tech University.

Babels. (s/d) Babels. Recuperat el 20 de juliol de 2020 de http://www.babels.org/

Bacelar Gouveia, Jorge. (1993). Constituição da República Democrática de S. Tomé e Príncipe, pp. 283-319. As constituições dos estados lusófonos. Editorial Notícias.

Baker, Mona. (2013). Translation as An Alternative Space for Political Action, pp. 23-47. Social Movement Studies: Journal of Social, Cultural and Political Protest, 12(1).

Baker, Mona. (2006). Translation and Activism. Emerging Patterns of Narrative Community, pp. 462-484. The Massachussets Review, 47(3).

Bakker, Peter. (1995). Pidgins, pp. 25-40. Pidgins and Creoles. An introduction. Ed. Jacques Arends, Pieter Muysken and Norval Smith. John Benjamin Publishing Company.

Bartoll, Eduard. (2015). Introducción a la Traducción Audiovisual. Ed. UOC.

Bastardas Boada, Albert. (2014). Ecología y sostenibilidad lingüística: una aproximación desde la (socio)complejidad, 
pp. 143-163. Eugenio Coseriu, in memoriam. XIV Jornadas de Lingüística. Cádiz: Universidad de Cádiz.

Batrina, Francesca. (2001). La investigación en traducción audiovisual: interdisciplinariedad y especifidad, pp. 161-176. ¡Doble o nada! Actas de la I y II Jornadas de doblaje y subtitulación. Ed. J. Sanderson. Alacant: Publicacions de la Universitat d'Alacant.

Behr, Thomas. (2003). Luigi Taparelli D'Azeglio, SJ (1793-1862) and the development of scholastic natural-law thought as a science of society and politics, pp. 99-115. Journal of Markets i Morality, 6(1).

Belmar, Guillem. (s/d). Las lenguas minorizadas de Europa Occidental. Diversidad lingüística.

Bello, Iraxis. (2008). China en África: entre la cooperación y el neocolonialismo. Revista Pueblos. Especial de Verano "África Subsahariana".

Benavides, Okuda Mayumi i Gómez-Restrepo, Carlos. (2005). Métodos en investigación cualitativa: triangulación, pp. 118124. Revista Colombiana de Psiquiatría, 34 (1). http://www.scielo.org.co/scielo.php?script=sci_arttextipid=S00 34-74502005000100008ilng=enitlng=es.

Birello, Marilisa i Sánchez-Quintana, Núria (2014). Tensiones en el sistema de creencias, representaciones y saberes de los docentes. ¿Oportunidades ante el cambio?, pp. 82-88. Aprender a ser docente en un mundo en cambio. Simposio internacional. Sancho, J. M., Correa, J. M., Giró, X. y Fraga, L. (Coord.). Barcelona: Dipòsit Digital de la Universitat de Barcelona. 
Boitel, Quentin. (2018). Proyectos culturales, políticas lingüisticas y justicia social. Las iniciativas de revitalización del náhaut en El Salvador, pp. 62-87. Como Bálsamo de Fierabrás. Cultura en tiempos y territorios de conflicto. Ed: Fernando Quiles, Ana Cielo Quiñones, Carmen Y. Cruz Rivas, Cristina Padilla Velasco. Universidad Pablo Olavide.

Bouchard, Marie-Eve. (2017). Linguistic variation and change in the Portuguese of São Tomé. Department of lingüístics. New York University.

Bula, Hernán Enrique i Fidalgo, Iker. (2016). Nuevas y viejas prácticas audiovisuales activistas de resistencia e intervención social y (tecno)política, pp. 61-87. Revista TOMA UNO, 5.

Caballero Rodríguez, Tamara i Metzger da Costa Gama, Douglas. (2007). Análisis sociológico de la pobreza en São Tomé y Príncipe, pp. 65-86, 114. Revista Santiago. Ed: Dirección de Información Científico Técnica de la Universidad de Oriente, Santiago de Cuba.

Caldeira, Arlindo Manuel. (2007-2008). Mestiçagem, estratégias de casamento e propriedade feminina no arquipélago de São Tomé e Príncipe nos séculos XVI, XVII e XVIII, pp. 49-72. Arquipélago. História. $2^{\circ}$ série, $\mathrm{XI}-\mathrm{XII}$.

Caldwell-Harris, Catherine L. (2019). Our language affects what we see. Scientific

American. https://www.scientificamerican.com/article/our-languageaffects-what-we-see/

Callejo Gallego, Javier. (2002). Observación, entrevista y grupo de discusión: el silencio de tres prácticas de investigación, pp. 409-422. Revista española de Salud Pública, 76(5). 
scielo.isciii.es/scielo.php?script=sci_arttextipid=S1135-

57272002000500004

Camps, Assumpta. (2019). Out of the dominant political agenda: translation and interpreting networks for social activism, pp. 923. Transfer: revista electrónica sobre traducción e interculturalidad, 14.

Carbonell Paris, Francesc. (2002). Decálogo para una educación intercultural, pp. 32-39. Monitor educador, 90.

Cardoso, Maria Manuela. (2004). Educação/Formação/Investigacão em São Tomé e Príncipe - Será uma aposta do país no caminho para o desenvolvimento?. A questão social no novo milénio. VIII Congresso Luso-Afro-Brasileiro de Ciências Sociais. Coimbra.

Cardoso, Maria Manuela. (2008). Educação em São Tomé e Príncipe. Ciclo Conversas sobre África 27 de maio de 2008. Faculdade de Letras da Universidade do Porto.

Cardoso, Hugo et al. (2015). Crioulos de base lexical portuguesa, pp. 670-691. Manual des anthologies, corpus et textes romanes. Maria lliescu i Eugeen Roegiest. Berlin: Mouton de Gruyter.

Carrasco Pérez, Encarnación i Sánchez-Quintana, Núria. (2013). Evolución de las creencias de los profesores de lenguas en aulas multiculturales y bilingües. Creando redes, estableciendo sinergias: la contribución de la investigación a la educación. I Seminario internacional REUNI+D, Barcelona.

Carreño, Eduardo A. (2013). África y la cooperación para el desarrollo: una reflexión desde la ética global pp. 241-249. Acta Bioethica, 19(2). 
Carrión Rabasco, Jesús i Martí Comas, Júlia. (2013). Cooperación al desarrollo S.A. Revista Pueblos, 59. http://www.revistapueblos.org/blog/2013/12/13/cooperacion-aldesarrollo-s-a/

Castaño Molina, Maㅡ de los Ángeles et al. (2017). Guía Práctica de Grupos de Discusión para principiantes. Universidad de Murcia.

de Ceita do Espírito Santo, Armindo. (2009). São Tomé e Príncipe: problemas e perspectivas para o seu desenvolvimento. Edições Colibri. Ed. Fernando Mão de Ferro.

Cenoz, Jasone i Gorter, Durk. (2011). A Holistic Approach to Multilingual Education: Introduction, pp. 339-343. Special issue: Toward a Multilingual Approach in the Study of Multilingualism in School Contexts. The Modern Language Journal, 95(3).

Centro Virtual Cervantes. (1997-2020). Sociolingüística. Recuperat el 20 de juliol de 2020 de https://cvc.cervantes.es/ensenanza/biblioteca_ele/diccio_ele/d iccionario/sociolinguistica.htm

Cerezo, Beatriz; Martínez Sierra, Juan José et al. (2018). PluriTAV: desarrollo de las competencias plurilingües mediante el uso de la traducción audiovisual. IV Congreso Nacional de Innovación Educativa y Docencia en Red (IN-RED 2018). Ed. Universitat de València.

Cerri, Chiara. (2010). La importancia de la metodología etnográfica para la investigación antropológica. El caso de las relaciones de valores en un espacio asociativo juvenil. Perifèria. Revista 
de recerca $i$ formació en antropologia, 13. revistaredes.rediris.es/Periferia/Articles/1-Cerri_periferia_articulo.pdf

Chaume Varela, Federico. (2009). Traducción Audiovisual, pp. 7382. Diccionario histórico de la traducción en España. Ed. Gredos.

Chaume Varela, Federico. (2012). Audiovisual Translation: Dubbing, pp. 6-10. Manchester, St. Jerome.

Chaume Varela, Federico. (2013). The turn of audiovisual translation: New audiences and new technologies, pp. 105-123. Translation Spaces 2. John Benjamins Publishing Company.

Chibaka, Evelyn Fogwe. (2018). Advantages of Bilingualism and Multilingualism: Multidimensional Research Findings. Multilingualism and Bilingualism. Beban Sammy Chumbow. IntechOpen.https://www.intechopen.com/books/multilingualism -and-bilingualism/advantages-of-bilingualism-andmultilingualism-multidimensional-research-findin

Ciekawi, Diana i Geschiere, Peter. (1998). Containing Witchcraft: Conflict Scenarios in Postcolonial Africa, pp. 1-14. African Studies Review, 41(3).

Ciudades y Gobiernos Locales Unidos (CGLU) i Comisión de Cultura de CGLU. (2018). La cultura en los objetivos de desarrollo sostenible: guía práctica para la acción local.

Clair, Robin Patric. (2003). The Changing Story of Ethnography, pp. 3-26. Expressions of Ethnography. Novel aproaches to qualitative methods. Ed. Robin Patric Clair. State University of New York Press, Albany. 
Clipflair. (2011). Clipflair. Aprenentatge de Ilengües mitjançant Revoicing i Captioning of Clips. Recuperat el 29 de juny de 2020 de http://clipflair.net/

Concha Malo, Miguel. (2003). El compromiso por la justicia social, una exigencia de la ética cívica y política, pp. 31-38. Revista Contaduría y Administración, 211.

Conselho Geral Independente. (2015). Relatório de Avaliação de Cumprimento Estratégico para a RTP e Parecer sobre as Obrigações Legais de Investimento em Produção Audiovisual e Cinematográfica Independente.

Cooper, Robert L. (1989). Language planning and social change. Cambridge University Press.

Cooperación Bierzo Sur. (2012-2013). Programa de evaluación geriátrica integral con ancianos de las casas sociales de Cruz Vermelha en Santo Tomé y Príncipe.

Cooperación Bierzo Sur. (2013). AYER, HOY Y MAÑANA: Las Personas de Edad como Agentes de Socialización en la comunidad de Santo Amaro.

Cooperación Bierzo Sur. (2013). Rehabilitación y mejora de las casas sociales para ancianos de la Cruz Vermelha de Santo Tomé y Príncipe en S. João de Angolares.

Cooperación Bierzo Sur. (2014). Estudio geriátrico y social de los ancianos de la CVSTP.

Cooperación Bierzo Sur. (2014). Evaluación del estado y necesidades de las casas sociales, centro de día y casas de acogida de la CVSTP para los ancianos. 
Cooperación Bierzo Sur. (2015). Valoración socio-sanitaria de las personas de edad de la comunidad de Santo Amaro y Bela Vista.

Cooperación Española. (2006-2008). Plan de Actuación Especial 2006-2008. Santo Tomé y Príncipe. Ministerio de Asuntos Exteriores y de Cooperación. Secretaria de Estado de Cooperación Internacional. Dirección General de Planificación y Evaluación de Políticas para el Desarrollo.

Copains, J. (2012). Etnografia-etnología-antropología. Tentativa de definición, pp. 31-34. Antropología y comparación cultural: métodos y teorías. Nuria Fernández Moreno. UNED.

Coseriu, Eugenio. (1981). La socio- y la etnolingüística: sus fundamentos y sus tareas, pp. 5-30. Anuario de Letras, 19. México.

Cravo, Carolina et al. (2010). Estudo Diagnóstico das ONG em São Tomé e Príncipe. Edição: ACEP-Associação para a Cooperação entre os Povos. Parceria: FONG-STP Federação das ONG em São Tomé e Príncipe.

CSA. (s/d). El papel del sector privado en las políticas de cooperación al desarrollo en América Latina y El Caribe. Estudio de casos seleccionados. Confederación Sindical de Trabajadores y Trabajadoras de las Américas.

Danan, M. (2004). Captioning and subtitling: Undervalued language learning strategies, pp. 67-77. Meta, 49(1).

Degawan, Minnie. (2019). Lenguas indígenas, conocimientos y esperanzas. El Correo de la Unesco. 2019-1. 
DeGraff, Michel. (2003). Against Creole exeptionalism, pp. 391-410. Language, 79(2).

Derhemi, Eda. (2002). Thematic Introduction: Protecting Endangered Minority Languages: Sociolinguistic Perspectives, pp. 150161. Protecting Endangered Minority Languages: Sociolinguistic Perspectives. International Journal on Multicultural Societies (IJMS), 4(2).

Derhemi, Eda. (2002). The endangered Arbresh language and the importance of standarised writing for its survival: the case of Piana degli Albanesi, Sicily, pp. 248-269. Protecting Endangered Minority Languages:Sociolinguistic Perspectives. International Journal on Multicultural Societies (IJMS), 4(2).

Díaz-Cintas. Jorge. (2001) La traducción audiovisual: el subtitulado, pp. 64-68. Salamanca: Almar.

Díaz-Cintas, Jorge i Remael, Aline. (2007). Audiovisual Translation: Subtitling, pp. 29-102. Manchester: St. Jerome.

Díaz-Cintas, Jorge. (2008). Teaching and learning to subtitle in an academic environment, pp. 89-105. The Didactics of Audiovisual Translation. Ed. Díaz Cintas, Jorge. Ámsterdam/Filadelfia: John Benjamins.

Díaz-Cintas, Jorge. (2010). Subtitling, pp. 344-349. Handbook of Translation Studies. Volume 1.

Díaz-Cintas. Jorge. (2012). Los subtítulos y la subtitulación en la clase de lengua extranjera, pp. 95-114. Abehache, Revista da Associação Brasileira de Hispanistas, 2(3). 
Direcção Nacional da Cultura de S.Tomé e Príncipe. (1984). Contos tradicionais santomenses. Ed. Caminho, SARL, Portugal.

Dollerup Cay i Orel-Kos Silvana. (2001). Co-printing. Translation without boundaries, pp. 285-300. Grenzen erfahren - sichtbar machen - überschreiter: Festschrift für Erich Prunč zum 60. Geburtstag. Frankfurt i Wien: Peter Lang.

Dolz, Joaquim. (2019). La règle du sept de la sociodidactique des langues, pp. 21-49. Ed. El Barkani, B. i Meksem, Z. Plaidoyer sur la variation. Mélanges en hommage à Marielle Rispail. Ed. El Barkani, B. i Meksem, Z. Caen: EME éditions.

Domínguez, Rafael. (2011). La crisis de identidad del sistema de ayuda. Nombres propios. Fundación Carolina. http://www.ciberoamericana.com/pdf/NPFC_Dominguez_May 011.pdf

DSTV. (s/d). Digital Satellite Television. Recuperat el 29 de juliol de 2020 de https://www.dstv.com/

Echeverri, J.A. i Romero Cruz, I.V. (2016). Agonía y revitalización de una lengua y un pueblo: los nonuya del Amazonas, pp. 135156. Forma y Función, 29(2).

El cine, el mundo y los derechos humanos. (s/d). Muestra de cine El Mundo y los Derechos Humanos. Recuperat el 29 de juny de 2020 de http://www.cineddhh.org/muestra-de-cine/

Ellsworth, T. (1992). Waiter, a dish of satellite, please!: Integrating subtitled video into your teaching, pp. 24-27. English Teaching Forum, 30(3). 
Emerson, Robert M. et al. (2013). Notas de campo na pesquisa etnográfica, pp. 355-388. Revista Tendências: Caderno de Ciências Sociais, 7.

Ernesto. (2014). Why people Pirate Game of Thrones, a Global Cost Breakdown. TorrentFreak. Recuperat el 20 de juliol de 2020 de https://torrentfreak.com/why-people-pirate-game-ofthrones-a-global-cost-breakdown-140413/

Ernesto. (2016). Game of Thrones' Most Torrented TV-Show of 2016. TorrentFreak. Recuperat el 20 de juliol de 2020 https://torrentfreak.com/game-of-thrones-most-torrented-tvshow-of-2016-161226/

Ernesto. (2017). Game of Thrones' Most Torrented TV-Show of 2017. TorrentFreak. Recuperat el 20 de juliol de 2020 https://torrentfreak.com/game-of-thrones-most-torrented-tvshow-of-2017-171226/

Espírito Santo, Carlos. (2016). Santomensidade e Texto. Edições Colibri.

Espírito Santo, Carlos. (1985). Situação atual da língua portuguesa nas ilhas de S. Tomé e Príncipe, pp. 253-260. Congresso sobre a situação actual da língua portuguesa no mundo Lisboa 1983. Vol. I. Lisboa: Instituto de Língua e Cultura Portuguesa.

Ethnologue (2019). Languages of the world. Recuperat el 12 de febrer de 2020 de https://www.ethnologue.com/

Evuleocha, Stevina. (2008). Nollywood and the home video revolution: implications for marketing videofilm in Africa, pp. 407-417. International Journal of Emerging Markets, 3(4). 
Fàbregues, Sergi i Paré, Marie-Hélène. (2010). El grupo de discusión y la observación participante en psicologia. Universitat Oberta de Catalunya.

Fase, Willem et al. (1992). Maintenance and loss of minority languages. Introductory remarks, pp. 3-13. Maintenance and Loss of Minority Languages. Edited by Willem Fase, Koen Jaspaert and Sjaak Kroon. Amsterdam.

Federici, Silvia. (2018). Caliban i la bruixa: dones, cos i acumulació primitiva (Trad. Marta Pera Cucarell). Virus Editorial. (Treball original publicat en 2004).

Feio, Joana. (2008). De étnicos a "étnicos": uma abordagem aos "angolares" de São Tomé e Príncipe. Instituto Superior de Ciências do Trabalho e Empresa. Departamento de Antropologia.

Feio, Joana. (2016a). Cabo-verdianos e São-tomenses de ascendência cabo-verdiana em São Tomé e Príncipe na atualidade: uma abordagem etnográfica, pp. 197-222. Diáspora Cabo-Verdiana: Temas em debate. Iolanda Évora. Lisboa: ISEG-CesA.

Feio, Joana. (2016b). Dos nós na garganta e outros registos dos diários de campo: STP é como sangrar clorofila, pp. 57-78. Trabalho de campo: envolvimento e experiências em antropologia. Humberto Martins, Paulo Mendes. Imprensa de Ciências Sociais. Universidade de Lisboa.

Ferguson, Gibson. (2006). Minority languages and language revitalisation, pp. 70-109. Language Planning and Education. Edinburgh Textbooks in Applied Linguistics. Ed. Alan Davis i Keith Mitchell. Edinburgh University Press. 
Fernández Salinas, Antonio Carlos. (2018). La ayuda y la cooperación internacional para el desarrollo: ejemplificación en Colombia. Universidad de Córdoba. Máster en Cultura de Paz, Derechos Humanos, Resolución de Conflictos y Educación.

Fernández, María del Carmen i López, Enrique. (2014). La dimensión educativa del cine, pp. 9-16. Making of: cuadernos de cine y educación. №107. Recuperat el 29 de maig de 2020 de http://www.centrocp.com/la-dimension-educativa-del-cine/

Ferrer Simó, M. R. (2006). Fansubs y scanlations: la influencia del aficionado en los criterios profesionales, pp. 27-43. Puentes: hacia nuevas investigaciones en la mediación intercultural. №6.

Festival Cine Mérida. (2017). Proyecto MedicaAcción «Píldoras audiovisuales para salvar el mundo».https://festivalcinemerida.com/cineclub/wpcontent/uploads/2017/10/CRONOGRAMA_MEDICACCION.pd $f$

Fishman, Joshua. (1967). Bilingualism with and without diglossia; diglossia with and without bilingualism, pp. 29-38. Journal of Social Issues. 23(2).

Fishman, Joshua. (2002). Endangered Minority Languages: Prospects for Sociolinguistic Research, pp. 270-275. Protecting Endangered Minority Languages: Sociolinguistic Perspectives. International Journal on Multicultural Societies (IJMS) 4(2).

Fishman, Joshua. (2004). Language maintenance, language shift and reversing language shift, pp. 406-426. The Handbook of 
Bilingualism. Tej K. Bhatia and William C. Ritchie. Blackwell publishing.

Fons Esteve, Montserrat. (1999). Alfabetització inicial i ús real de la llengua escrita a l'aula. La galera: Barcelona.

Fontaneda, Eugenio. (2015). Mujeres de cine. Ecos de Hollywood en España, 1914-1936. Ministerio de Asuntos Exteriores y de Cooperación, AECID. http://bibliotecadigital.aecid.es/bibliodig/es/catalogo_imagenes /grupo.cmd?path=1008546

Francia en Bolivia. Embajada francesa en La Paz. (2019). Cooperación lingüística y educativa. Recuperat el 30 de juny de 2020 de https://bo.ambafrance.org/Cooperacion-linguisticay-educativa

Frasquet Porta, Lourdes. (2017). La Reunió: regular l'educació per destruir una llengua, pp. 105-119. Les llengües minoritzades en l'ordre postmonolingüe. Col-lecció «Estudis sobre la traducció». Eds. Esther Monzó Nebot, Joan Jiménez Salcedo. Castelló de la Plana: Publicacions de la Universitat Jaume I, D.L. 2017, 22.

Fuentes Luque, Adrián. (2017). Hollywood Stands Up: Mapping Nigeria's Audiovisual Sector, pp. 130-153. Translation Studies beyond the Postcolony. Marais, Kobus y Feinauer, Ilse (eds.) Newcastle upon Tyne: Cambridge Scholars Publishing.

Fueyo Gutiérrez, Aquilina i Fernández del Castro, José Ignacio. (2012). Hacer visible lo cotidiano a través del cine: la perspectiva de género en la Educación para el Desarrollo. REIFOP, 15(2). 
Fuller, C. i Parry, J. (1989). 'Petulant Inconsistency'?: The Intellectual Achievement of Edmund Leach, pp. 11-14. Anthropology Today, 5(3).

Fundéu. (2011). Lenguas minoritarias y lenguas minorizadas. Recuperat el 22 de juliol de 2020 de https://www.fundeu.es/recomendacion/lenguas-minoritarias-ylenguas-minorizadas-52/

Galeano, María Eumelia. (2004). Diseños de proyectos en la investigación cualitativa, pp. 44-60. Fondo Editorial Universidad EAFIT.

Game of Thrones, HBO'S Sweeping New Fantasy Series, Begins April 17 on HBO Canada (2011). Newswire. Recuperat el 20 de juliol de 2020 de web.archive.org/web/20160821182205/http://www.newswire.c a/news-releases/game-of-thrones-hbos-sweeping-newfantasy-series-begins-april-17-on-hbo-canada-507870131.html

Garabide Elkartea. (s/d). La experiencia vasca. Claves para la recuperación lingüística e identitaria. Coordinador: Alberto Barandiaran.

Garabide Elkartea. (s/d). La estandarización de la lengua. La recuperación del euskera II. Coordinador: Alberto Barandiaran.

Garabide Elkartea. (s/d). Los medios de comunicación. La recuperación del euskera III. Coordinador: Alberto Barandiaran.

Garabide Elkartea. (s/d). La enseñanza. La recuperación del euskera IV. Coordinador: Alberto Barandiaran. 
Garabide Kultur Elkartea. (2015-2016). Cooperación lingüística: análisis básico en la búsqueda de una estrategia propia. Eusko Jaurlaritza. Garabide.

García, Ofelia i Lin, Angel M. Y. (2016). Translanguaging in bilingual education. Bilingual and Multilingual Education (Encyclopedia of Language and Education, Vol. 5). Dordrecht: Springer.

García León, Javier Enrique. (2014). Una visión global de las lenguas criollas. Perspectivas y retos de la criollística, pp. 5164. Folios: revista de la Facultad de Humanidades, 39. Universidad Pedagógica Nacional.

García Sanz, María Paz i Martínez Clares, Pilar. (2012). Guía práctica para la realización de trabajos fin de grado y trabajos fin de máster. Universidad de Murcia.

Garrido Abellán, Yaiza. (2014). Comparación de subtítulos profesionales y fansubs en un capítulo de la serie Breaking Bad (Vince Gilligan, 2008). Trabajo Final de Grado. Traducción e Interpretación. Universitat Jaume I.

Gartenberg, Chaim. (2019). Game of Thrones' season 8 premiere was pirated almost 55 million times in the first 24 hours. The Verge. Recuperat el 30 de juny de 2020 de https://www.theverge.com/2019/4/17/18412159/game-ofthrones-got-season-8-premiere-pirated-55-million-times-first24-hours-hbo

Gernsbacher, Morton Ann. (2015). Video Captions Benefit Everyone, pp. 195-202. Policy Insights from the Behavioral and Brain Sciences, 2(1). 
Gimeno, Francisco i Montoya, Brauli. (1989). Sociolingüística. Biblioteca Lingüística Catalana. Universitat de València

Gómez, Chema. (2015). Juego de Tronos, emisión simultánea España/USA. IGN España. Recuperat el 30 de juny de 2020 de https://es.ign.com/juego-de-tronos/91778/news/juego-detronos-emision-simultanea-espana-usa

Gómez Contreras. (2014). Del desarrollo sostenible a la sustentabilidad ambiental, pp. 115-136. Revista Facultad Ciencias Económicas. 22(1).

Gómez-Restrepo, Carlos et al. (2016). Salud mental, sufrimiento emocional, problemas i transtornos mentales de indígenas colombianos. Datos de la Encuesta Nacional de Salud Mental 2015, pp. 119-126. Revista Colombiana de Psiquiatría, 45 (S1). http://www.scielo.org.co/pdf/rcp/v45s1/v45s1a16.pdf

Gómez Rodríguez, María Concepción. (2003). Breve aproximación a la antropología lingüística, pp. 467-472. Asociación de Jóvenes Lingüistas, 14.

Gonçalves de Género, Esterline. (2012). Análise da Estratégia de Desenvolvimento da União Africana: uma abordagem geosocial aplicada a São Tomé e Príncipe. Universidade Técnica de Lisboa. Instituto Superior de Ciências Políticas e Sociais.

Gonçalves, Rita. (2012).Mudança lingüística e variação no português de São Tomé, pp. 413-430. Actas do Colóquio Internacional São Tomé e Príncipe numa perspectiva interdisciplinar, diacrónica e sincrónica. Instituto Universitário de Lisboa (ISCTE-IUL), Centro de Estudos Africanos (CEA-IUL), Instituto de Investigação Científica Tropical (IICT). Lisboa. 
Gonçalves, Rita i Hagemeijer, Tjerk (2015). O português num contexto multilingue: $O$ caso de São Tomé e Príncipe, pp. 87107. Revista Científica da Universidade Eduardo Mondlane: Série Letras e Ciências Sociais, 1(1).

González Gil, Teresa i Cano Arana, Alejandra. (2010). Introducción al análisis de datos en investigación cualitativa: Tipos de análisis y proceso de codificación. Nure Investigación, 45.

González-Iglesias, David J. (2011). Análisis diacrónico de la velocidad de presentación de subtítulos para DVD, pp. 211218. TRANS Revista de Traductología, 15.

Guion, Lisa A., et al. (2011). Triangulation: Establishing the Validity of Qualitative Studies. Institute of Food and Agricultural Sciences. Florida: University of Florida. EDIS 2002 (6) https://journals.flvc.org/edis/article/view/108267

Guyot, Jacques. (2010). La diversidad lingüística en la era de la mundialización, pp. 47-61. Historia y comunicación social, 15.

Hagemeijer, Tjerk. (2009). As Línguas de S. Tomé e Príncipe, pp. 1 27. Revista de Crioulos de Base Lexical Portuguesa e Espanhola, 1.1.

Hagemeijer, Tjerk. (2016). O português em contacto em África, pp. 43-67. Manual da lingüística portuguesa. Ed. A.M. Martins i E. Carrilho, Berlim: Mouton de Gruyter.

Hagemeijer, Tjerk (2013). The Gulf of Guinea creoles: genetic and typological relations, pp. 163-206. Creole languages and linguistic typology. Ed. Parth Bhatt i Tonjes Veenstra (Benjamins Current Topics, 57). Amsterdam, Philadelphia: John Benjamins [reprint of Hagemeijer 2011, JPCL]. 
Hagemeijer, Tjerk; Généreux, Michel et al. (2014). The Gulf of Guinea creole corpora, pp. 523-529. Proceedings of the he 9th International Conference on Language Resources and Evaluation (LREC). Ed. N. Calzolari et al. Reykjavik: European Language Resources Association.

Hagemeijer, Tjerk; Zamora, Armando; et al. (2014). Santome corpus. Centro de Linguística da Universidade de Lisboa. Recuperat el 20 de juliol de 2020 de http://alfclul.clul.ul.pt/CQPweb/Santome/

Hagemeijer, Tjerk. (2018). From creoles to Portuguese. Language shift in São Tomé and Príncipe, pp. 169-184. The Portuguese Language Continuum in Africa and Brazil. John Benjamins Publishing Company.

Hagemeijer, Tjerk et al. (2018). Línguas e Políticas Linguísticas em São Tomé e Príncipe, pp. 54-59. Políticas Linguísticas em Português. Lidel.

Hallett, Darcy et al. (2007). Aboriginal language knowledge and youth suicide, pp. 392-399. Science Direct. Cognitive Development, 22. https://web.uvic.ca/ lalonde/manuscripts/2007CogDevt.pdf

HEGOA. (2005-2006). Diccionario de Acción Humanitaria y Cooperación al Desarrollo. Dins Recursos para el desarrollo humano, la educación global y la participación ciudadana. Universidad del País Vasco. Recuperat el 20 de juliol de 2020 de http://www.dicc.hegoa.ehu.es/

Herrero, Carmen et al. (2013). Film in Language Teaching Association. Manchester, UK. Recuperat I'1 de juliol de https://www.filta.org.uk/index.php 
Herrmann, François. (2012). Translating for Humanity. In response to the demand for pro bono translation services worldwide... Translational. Journal of the Northern California Translators Association. Recuperat el 20 de juliol de 2020 de http://www.translorial.com/ethics/translating-for-humanity/

Hibberd, James. (2011). Game of Thrones' premiere revelead. Entertainment Weekly. Recuperat el 20 de juliol de 2020 de https://ew.com/article/2011/01/07/game-of-thrones-premieredate/

Hidalgo, Alberto; Rodríguez, Francisco. J. et al. (2004). Cuestiones y conceptos básicos sobre cooperación y bienestar social, pp. 13-69. Cooperación al desarrollo y bienestar social. Eikasia.

Hinton, Leanne et al. (2018). Language Revitalization as a Growing Field of Study and Practice. The Routledge Handbook of Language Revitalization. Routledge. Ed. Leanne Hinton, Leena Huss i Gerald Roche.

Hlibowicka-Weglarz, Barbara. (2016). Pidgin, língua franca, sabir. Um estudo terminológico, pp. 35-41. Romanica Olomucensia, 1.

Hokkanen, Sari. (2017). Analysing personal embodied experiences: Autoethnography, feelings and fieldwork, pp. 24-35. The International Journal for Translation i Interpreting Research, $9(1)$.

Holmes, J. i Wilson, N. (2017). What do Sociolinguistics Study?, pp. 1-15. An Introduction to Sociolinguistics. London: Routledge 
Hornberger, Nancy H. (2005). Voz y Biliteracidad en la Revitalización de Lenguas Indígenas: Prácticas Contenciosas en Contextos Quechua, Guaraní y Maori, pp. 53-73. Polifonia: Revista de Letras, 10.

Huberman, A. Michael i Miles, Matthew B. (1994). Data management and analysis methods, pp. 428-444. Handbook of Qualitative Research. Eds: Denzin, N.K i Lincon, Y.S. Thousand Oaks, CA: Sage.

Huberman, A. Michael i Miles, Matthew B. (2000). Métodos para el manejo y análisis de datos, pp. 253-300. Por los rincones. Antología de métodos cualitativos en la investigación social. Eds. Catalina A. Denman i Jesús Armando Haro. El Colegio de Sonora.

Hurtado Albir, Amparo. (2011). Traducción y traductología. Ed. Cátedra.

Instituto Nacional de Estatística. (2003). A mulher em São Tomé e Príncipe. III Recenseamento Geral da População e Habitação, 2001. São Tomé e Príncipe.

Instituto Nacional de Estatística. (2012). Mulheres em São Tomé e Príncipe. Resultados Nacionais do IV Recenseamento Geral da População e Habitação, 2012. São Tomé e Príncipe.

Instituto Nacional de Estatística. (2012). População Portadora de Deficiência. Resultados Nacionais do IV Recenseamento Geral da População e Habitação, 2012. São Tomé e Príncipe.

Instituto Nacional de Estatística. (2012). Características Demográficas da População Idosa. São Tomé e Príncipe. 
Instituto Nacional de Estatística. (2012). Condições de vida dos idosos. São Tomé e Príncipe.

Instituto Nacional de Estatística. (2012). Características Socioeconómicas dos Idosos. São Tomé e Príncipe.

Instituto Nacional de Estatística. (2013). Resultados Nacionais do IV Recenseamento Geral da População e Habitação, 2012. São Tomé e Príncipe.

Instituto Nacional de Estatística. (2016). Boletim Estatístico de Educação. São Tomé e Príncipe.

Instituto Nacional de Estatística. (2018). Instituto Nacional de Estatística República Democrática de São Tomé e Príncipe. Recuperat l'1 de juliol de 2020 de https://www.ine.st/

Irvine, J.T i Gal, S. (2000). Language ideology and linguistic differenciation, pp. 35-84. Regimes of language: ideologies, polities and identities. Ed. P.V Kroskrity. Santa Fe: School of American Research Press.

Jarvey, Natalie. (2015) Game of Thrones' Piracy Soars Ahead of Season 5 Premiere. The Hollywood Reporter. Recuperat el 20 de juliol de 2020 de https://www.hollywoodreporter.com/news/game-thronespiracy-soars-season-787594

Jessner, Ulrike. (2008). Teaching third languages: Findings, trends and challenges, pp. 15-56. Language Teaching. 41(1). Cambridge University Press. 
Jociles Rubio, María Isabel. (2016). La observación participante: ¿consiste en «hablar con informantes»?, pp. 113-124. Quaderns-e. Institut Català d'Antropologia, 21(1).

Justo, David. (2019). HBO pone fecha al final de 'Juego de Tronos' mediante un nuevo avance. Cadena Ser. Recuperat el 20 de juliol de 2020 de https://cadenaser.com/ser/2019/01/14/television/1547446316_ 250369.html

Kain, Erik. (2012). International Audiences Have Few Chocies to Legally Watch HBO's 'Game of Thrones'. Recuperat el 20 de juliol de 2020 de https://www.forbes.com/sites/erikkain/2012/05/10/international -audiences-have-few-choices-to-legally-watch-hbos-game-ofthrones/\#33d0f77a1a5e

Kamen, Matt. (2015). Game of Thrones tops 2015's pirated TV show. The Daily Telegraph. Recuperat el 20 de juliol de 2020 de https://www.wired.co.uk/article/game-of-thrones-tops-piracycharts-2015

Kibera Girls Soccer Academy. (2012). Kibera Girls Soccer Academy. Thriving Girls Change The World. Recuperat el 29 de juliol de 2020 de http://www.kiberagirlssocceracademy.org/

Kruger Jan-Louis et al. (2007). Subtitling and the promotion of multilingualism: the case of marginalised languages in South Africa, pp. 35-47. A Tool for Social Integration? Audiovisual Translation from Different Angles. Linguistica Antverpiensia 6. Eds. Remael, Aline i Neves, Josélia.

La Poderosa. (2015). La Poderosa. Quito, Ecuador. Recuperat el 20 de juliol de 2020 de http://www.lapoderosa.org/en/ 
Laban, Michel. (2002). São Tomé e Príncipe. Encontro com escritores. Ed. Fundação Enginheiro António de Almeida.

Lappalainen, Rilli i Álvarez Rivas, David. (s/d). ED: una estrategia imprescindible para el futuro de la cooperación. Educación para el Desarrollo. Una estrategia de cooperación imprescindible. Grupo de Educación para el Desarrollo de la Congde. Coordinadora de ONG para el Desarrollo- España.

LaPier, Rosalyn. (2018). How the loss of native american language affects our understanding of the natural world, $s / p$. The Conversation. Recuperat el 20 de juliol de 2020 de https://theconversation.com/how-the-loss-of-native-americanlanguages-affects-our-understanding-of-the-natural-world103984

Lemus, Jorge E. (2008). Un modelo de revitalización lingüística: el caso del náhuat/pipil de El Salvador, pp. 127-149. Identità delle Comunità Indigene del Centro America, Messico e Caraibi. Trieste University-IILA.

Lemus, Jorge E. (2015). El pueblo pipil y su lengua: de vuelta a la vida. Universidad Don Bosco.

Lemus Delgado, Daniel Ricardo. (2017). Regímenes de verdad: el Comité de Ayuda al Desarrollo y la narrativa histórica de la Cooperación Internacional para el Desarrollo, pp. 27-54. Historia de la cooperación internacional desde una perspectiva crítica. Barranquilla, Col. Sello Editorial. Uniautónoma. Serie: debates RIACI. Ed: Rafael Domínguez i Gustavo Rodríguez Albor.

Lertola, Jennifer. (2012). The effect of the subtitling task on vocabulary learning, pp. 61-70. Translation Research Project 
4. Eds. A. Pym and D. Orrego-Carmona. Tarragona: Intercultural Studies Group, Universitat Rovira i Virgili.

Liddicoat, Anthony J. i Bryant Pauline. (2001). Language planning and language revival: a current issue in language planning, pp. 137-140. Current issues in language planning, 2(2).

Lo Brutto, Giuseppe. (2017). A propósito de la Cooperación Internacional y del Desarrollo: una visión más realista, pp. 5574. Historia de la cooperación internacional desde una perspectiva crítica. Barranquilla, Col. Sello Editorial. Uniautónoma. Serie: debates RIACI. Ed: Rafael Domínguez i Gustavo Rodríguez Albor.

Lombard, J. (2012). Contenido y objetivos de la etnología: etnología, etnografía, antropología, pp. 35-42. Antropología y comparación cultural: métodos y teorías. Nuria Fernández Moreno. UNED.

López, Carlos D. et al. (2005). Desarrollo sustentable o sostenible: una definición conceptual, pp. 28-34. Horizonte Sanitario. 4(2). Universidad Juárez Autónoma Tabasco.

Lorenzino, Augusto Gerardo. (1996). Uma avaliação socio-linguística sobre São Tomé e Príncipe. Congresso Internacional sobre o Português: Actas, vol. I-III. Inês Duarte e Isabel Leiria (orgs.). Lisboa: Associação Portuguesa de Linguística e Edições Colbri, vol. II.

Lummis, C. Douglas. (2007). Ruth Benedict's Obituary for Japanese Culture. The Asia-Pacific Journal. Japan focus. 5(7). https://apjjf.org/-C--Douglas-Lummis/2474/article.pd 
Lunin, Mikhail i Minaeva, Ludmila. (2015). Translated subtitles language learning method: a new practical approach to teaching English, pp. 268-275. Procedia - Social and Behavioral Sciences, 199.

Macias Barres, David Abraham. (2012). La cooperación lingüística francesa y la enseñanza del francés en la educación secundaria ecuatoriana, pp. 117-128. Crisol, Centre de Recherches Ibériques et Ibéro-Américaines (CRIIA) Université Paris Ouest-Nanterre. France - Équateur: regards croisés. Numéro spécial à l'occasion des quarante ans du Centre d'Études Équatoriennes de l'Université Paris Ouest: 1972-2012, 17.

Madureira, Maria do Céu. (2012). Plantas Medicinais e Medicina Tradicional de S.Tomé e Príncipe, pp. 433-453. Actas do Colóquio Internacional São Tomé e Príncipe numa perspectiva interdisciplinar, diacrónica e sincrónica. Instituto Universitário de Lisboa (ISCTE-IUL), Centro de Estudos Africanos (CEA-IUL), Instituto de Investigação Científica Tropical (IICT).

Magid, Jacob. (2012). The Marshall Plan, pp. 1-7. Advances in Historical Studies, 1(1).

Mahadevan, Renuka. (2017). Examining domestic and international visits in Australia's aboriginal tourism. Tourism Economics, 24. https://www.researchgate.net/publication/315996151_Examini ng_domestic_and_international_visits_in_Australia's_Aborigin al_tourism

Maja, Innocent. (2008). Towards the Human Rights Protection of Minority Languages in Africa. Recuperat el 20 de juliol de 2020 
https://www.nyulawglobal.org/globalex/Minority_Languages_Af rica.html

de Manuel Jerez, Jesús et al. (2004). Traducción e interpretación: Voluntariado y compromiso social. El compromiso social en traducción e interpretación: Una visión desde ECOS, traductores e intérpretes por la solidaridad. Puentes, 4.

Marian, V. i Shook, A. (2012). The cognitive benefits of being bilingual.

Cerebrum 2012, 13. https://www.ncbi.nlm.nih.gov/pmc/articles/PMC3583091/

Marky, Sum. (1963). Vila Flogá. Distribuidor: M.C. Castro, Lisboa.

Martí Ferriol, José Luis. (2012). Nueva aproximación al cálculo de velocidades de lectura de subtítulos, pp. 39-48. TRANS. REVISTA DE TRADUCTOLOGÍA,16(1).

Martín Camacho, José Carlos. (2018). La Etnolingüística como disciplina científica. Propuesta de definición y ámbito de estudio, pp. 584-591. Actas do XIII Congreso Internacional de Lingüística Xeral, Vigo.

Martínez Osés, Pablo. (2013). ¿Tiene futuro la cooperación? Obstáculos y retos ante la agenda post 2015. Revista Pueblos, 59. http://www.revistapueblos.org/blog/2013/12/11/tiene-futuro-lacooperacion-obstaculos-y-retos-ante-la-agenda-post-2015/

Martínez Sánchez, Joaquín José. (2017). ¿Por qué deberían contribuir los investigadores a la revitalización de lenguas? Revitalizar la lingüística para que sirva a la resistencia de los pueblos originarios y migrantes, pp. 204-223. Onomázein - 
Número Especial. Las lenguas amerindias en Iberoamérica: retos para el siglo XXI.

Marzà, Anna i Torralba, Gloria (2014). Incidental Language Learning through Subtitled Cartoons: Is it Possible in a Dubbing Country?, pp. 199-219. Subtitles and Language Learning: Principles, strategy and practical experiences, (electronic resource). Switzerland. Ed. Peter Lang.

Mata, Inocência. (1998). Diálogo com as ilhas. Sobre a Cultura e Literatura de São Tomé e Príncipe. Edições Colibri. Ed. Fernando Mão de Ferro.

Mata, Inocência. (2004). A suave pátria: reflexões político-culturáis sobre a sociedade São-Tomense. Edições Colibri. Ed. Fernando Mão de Ferro.

Maturana Moreno, Gerson i Garzón Daza, Cecilia. (2015). La etnografía en el ámbito educativo: una alternativa metodológica de investigación al servicio docente, pp. 192205. Revista Educación y Desarrollo Social, 9 (2). Universidad Militar Nueva Granada. Bogotá D.C.

McCarty, Teresa L. (2018). Community-Based Language Planning. Perspectives from Indigenous Language Revitalization. The Routledge Handbook of Language Revitalization. Routledge. Ed. Leanne Hinton, Leena Huss i Gerald Roche.

McKernan, James. (1999). Investigación-acción y currículum. Métodos y recursos para profesionales reflexivos, pp. 114141. Ed. Morata, Madrid. 
MECCC. (2016). Boletim Estatístico 2015/2016. Ministério de Educação, Cultura, Ciência e Comunicação. República Democrática de São Tomé e Príncipe.

Media Consulting Group. (2011). Study on the use of subtitling. The potential of subtitling to encourage foreign language learning and improve the mastery of foreign languages. Final Report EACEA/2009/01.

Medina López, Javier. (2002). Lenguas en contacto, pp. 11-26. Cuadernos de Lengua Española, 47.

Mendieta Izquierdo, Giovane. (2015). Informantes y muestreo en investigación cualitativa, pp. 1148-1150. Investigaciones Andina, 17(30). Fundación Universitaria del Área Andina. Pereira, Colombia.

Mills, Jean. (2004). Mothers and Mother Tongue: Perspectives on Self-Construction by Mothers of Pakistani Heritatge, pp. 161191. Negotiation of Identities in Multilingual Contexts. Ed. Aneta Pavlenko i Adrian Blackledge.

Ministério da Educação, Cultura e Formação. (2012). Carta de Política Educativa São Tomé e Príncipe (Visão 2022). Primera versão Maio 2012.

Moncayo, María Fernanda. (2016). La etnografía virtual como método de investigación en el diagnóstico de la comunicación corporativa, pp. 114-125. Investigación en Comunicación. Estrategas. Facultad de Comunicación y Artes Visuales. Universidad de las Américas. Recuperat el 20 de juliol de 2020 de https://docplayer.es/67481594-La-etnografia-virtualcomo-metodo-de-investigacion-en-el-diagnostico-de-lacomunicacion-corporativa.html 
Monje Álvarez, Carlos Arturo. (2011). Metodología de la investigación cuantitativa y cualitativa. Guía didàctica. Universidad Surcolombiana. Facultad de Ciencias Sociales y Humanas. Programa de Comunicación Social y Periodismo. Neiva.

Monteoliva García, Eloísa. (2008). La traducción solidaria, pp. 235239. Actas del IV Congreso "El español, lengua de traducción". El español, lengua de traducción para la cooperación y el diálogo. Esletra. Madrid.

Montolio Orts, Irene. (2015). Accesibilidad y subtitulación de escenas cinemáticas en los videojuegos: Análisis del videojuego El Padrino I y propuesta de subtitulado para sordos (SPS). Trabajo Final de Grado Traducción e Interpretación. Universitat Jaume I.

Moreno-Fernández, Francisco. (2005). Nuevos instrumentos en la planificación lingüística del español: ortografías, gramáticas, diccionarios... y más, pp. 15-34. Actas del II simposio José Carlos Lisboa de didáctica del español como lengua extranjera del Instituto Cervantes de Río de Janeiro.

Moreno García, María Esther. (2010). El plurilingüismo como necesidad en la sociedad actual, pp. 120-126. Pedagogía Magna, 8.

Mosquera Villegas, Manuel Andrés. (2008). De la etnografía antropológica a la etnografía virtual. Estudio de las relaciones sociales mediadas por Internet, pp. 532-549. Fermentum. Revista Venezolana de Sociología y Antropología, 18(53). Universidad de los Andes. Mérida, Venezuela. 
Mugarik Gabe. (s/d). Muestra de cine y cooperación "contra las violencias machistas» en Guipuzkoa. Recuperat el 20 de juliol de 2020

de

https://www.mugarikgabe.org/es/2011/12/15/muestra-de-ciney-cooperacion-qcontra-las-violencias-machistasq-en-gipuzkoa/

Mufwene, Salikoko. (2002). Colonisation, Globalisation, and the Future of Languages in the Twenty-first Century, pp. 162-193. Protecting Endangered Minority Languages: Sociolinguistic Perspectives. International Journal on Multicultural Societies (IJMS) 4(2).

Muñoz, Juan José. (2007). El cine como experiencia antropológica y ética, pp. 17-35. Revista de comunicación, 6.

Muñoz Solla, Ricardo. (1998). Aspectos sociolingüísticos en la revitalización del hebreo moderno, pp. 225-229. Interlingüística, https://dialnet.unirioja.es/servlet/articulo?codigo $=897056$

Muñoz- Torrent, Xavier. (2005). Els hereus de Mé Xinhô. Medicina tradicional i salut pública a São Tomé e Príncipe. (Homenatge a Sum Ernesto, 1931-2014), pp. 9-24. Sanitat a l'Àfrica. Barcelona, Drassanes per Àfrica.

Murillo, F. Javier i Hernández, Reyes. (2011). Hacia un concepto de justicia social, pp. 8-23. Revista Iberoamericana sobre Calidad, Eficacia y Cambio en Educación, 4(4).

Muysken, Pieter. (2002). Uchumataqu: Research in Progress on the Bolivian Altiplano, pp. 235-247. Protecting Endangered Minority Languages: Sociolinguistic Perspectives. International Journal on Multicultural Societies (IJMS), 4(2). 
Naciones Unidas México. (2019). En febrero 2020, México acogerá a la comunidad internacional en el evento que definirá la agenda sobre el Decenio Internacional de las Lenguas Indígenas, s/p. Recuperat el 20 de juliol de 2020 de http://www.onu.org.mx/en-febrero-2020-mexico-acogera-a-lacomunidad-internacional-en-el-evento-que-definira-la-agendasobre-el-decenio-internacional-de-las-lenguas-indigenas/

Nascimento, Augusto. (2004). A passagem de coolies por S. Tomé e Príncipe, pp. 77-112. Arquipélago História, 2a série, VIII.

Nascimento Augusto. (2010). Histórias da llha do Príncipe. Município de Oeiras.

Nascimento, Augusto. (2001). Mutações Sociais e Políticas em S.Tomé e Príncipe nos séculos XIX-XX: uma síntese interpretativa. Centro de Estudios Africanos e Asiáticos, Instituto de Investigação Científica Tropical.

Nascimento, Augusto. (2000). Relações de poder e quotidiano nas roças de S. Tomé e Príncipe de finais de Oitocentos e meados do presente século.

Neto Amado, Lúcio. (2014). Manifestações culturáis são-tomenses. Chiado Editora. Ed. Camila Figueiredo.

Neto Amado, Lúcio. (2012). Os mares do meu Arquipélago. São Tomé.

Neves, J. (2005). Audiovisual Translation: Subtitling for the Deaf and Hard-of-Hearing. Tesi doctoral. Roehampton University. Recuperat el 24 de juliol de 2020 de http://citeseerx.ist.psu.edu/viewdoc/download?doi=10.1.1.129. 1405\&rep=rep $1 \&$ type $=$ pdf 
Neves, Paulo. (2009). Estórias de Vida. ED. UNEAS (União Nacional dos Escritores e Artistas de S. Tomé e Príncipe).

Nolla Cao, Nidia. (1997). Etnografía: una alternativa más en la investigación pedagógica, pp. 107-115. Educación Médica Superior, 11(2).

ONU. (s/d). Día Mundial de la Justicia Social, 20 febrero. Recuperat el 20 de juliol de 2020 de www.un.org/es/events/socialjusticeday/

ONU. (1945). Capítulo 1: propósitos y principios. Carta de las Naciones Unidas y Estatuto de la Corte Internacional de Justicia.

Opdenakker, Raymond. (2006). Advantages and disadvantages of four interview techniques in qualitative research. Forum Qualitative Sozialforschung/Forum: Qualitative Social Research, 7(4). Art.11. Recuperat el 20 de juliol de 2020 de www.qualitativeresearch.net/index.php/fqs/article/view/175/391\#gcit

Orrego Carmona, David. (2013). Avance de la traducción audiovisual: desde los inicios hasta la era digital, pp. 297-320. Mutatis Mutandis: Revista Latinoamericana de Traducción. $6(2)$.

Ortega Carpio, $M^{a}{ }^{a}$ Luz. (2008). La Educación para el Desarrollo: dimensión estratégica de la cooperación española, pp. 15-18. Cuadernos Internacionales de Tecnología para el Desarrollo Humano. Ingeniería Sin Fronteras, 7.

Oster et al. (2014). Cultural continuity, traditional Indigenous language, and diabetes in Alberta First Nations: a mixed 
methods of study. International Journal for Equity in Health, 13 (92).

https://equityhealthj.biomedcentral.com/articles/10.1186/s1293 9-014-0092-4

Pandharipande, Raheswari. (2002). Minority matters: issues in Minority Languages in India, p. 213-234. Protecting Endangered Minority Languages: Sociolinguistic Perspectives. International Journal on Multicultural Societies (IJMS) 4(2).

Pantoja, Selma. (2008). Do socialismo africano à globalização: o caso de São Tomé e Príncipe, pp. 185-187. Textos de História, 16(1).

Parra Sabaj, María Eugenia. (1998). La etnografía de la educación, pp. 64-81. Cinta moebio, 3. Revista de Epistemología de Ciencias

Sociales.

https://www.moebio.uchile.cl/03/frprin04.html

de Pedro Ricoy, Raquel. (2017). To interview or not to interview: a critical approach to assessing end-users' perceptions of the role of 21st century indigenous interpreters in Peru, pp. 36-50. The International Journal for Translation i Interpreting Research 9(1).

Pérez-Garzón, Carlos Andrés. (2019). ¿Qué es justicia social? Una nueva historia de su significado en el discurso jurídico transnacional. Revista Derecho del Estado, 43.

Pettit, Stacie Kae. (2011). Teachers' Beliefs About English Language Learners in the Mainstream Classroom: A Review of the Literature, pp. 123-147. International Multilingual Research Journal, 5 (2). 
Pinho, Isis da Costa. (2008). Diversidade lingüística e Identidade: as micro-decisões na manutenção/perda de uma língua materna minoritária, pp. 78-94. Contingentia. 3(1). http://seer.ufrgs.br/index.php/contingentia/article/view/4159/22 00

del Pino, Cristina i Aguado, Elsa. (2012). Internet, Televisión y Convergencia: nuevas pantallas y plataformas de contenido audiovisual en la era digital. El caso del mercado audiovisual online en España, pp. 57-75. Observatorio (OBS) Journal, $6(4)$.

Pinto Pajares, Daniel. (2018). Representaciones ideológicas de las lenguas: análisis comparativo de las ideologías lingüísticas en las clases altas gallega y catalana, pp. 46-68. Tese de Doutoramento. Universidade de Vigo.

PlanetRead (2018a). AniBooks: Scalable and likeable, but readable? Recuperat el 20 de juliol de 2020 de https://www.planetread.org/pdf/Eye\%20Tracking\%20Study\%2 0of\%20AniBooks\%20Draft\%20Report\%20(June\%202018).pdf

PlanetRead (2018b). AniBooks for early-grade reading. Recuperat el 20 de juliol de https://www.planetread.org/pdf/AniBooks\%20for\%20EGR\%20 PlanetRead.pdf

PluritAV (2020). PluriTAV. La traducció audiovisual com a ferramenta per al desenvolupament de la competència plurilingüe a l'aula. Recuperat el 6 de juliol de 2020 de http://citrans.uv.es/pluritav/ 
PNUD .(2002). Relatório do Desenvolvimento Humano em São Tomé e Príncipe. As mudanças de 1990 a 2002 e o desenvolvimento humano.

Portal Web AECID. (s/d). ¿Qué es la educación para el desarrollo?. Recuperat el 20 de juliol de 2020 de http://www.aecid.es/ES/la-aecid/educaci\%C3\%B3n-ysensibilizaci\%C3\%B3n-para-eldesarrollo/\%C2\%BFqu\%C3\%A9-es-la-educaci\%C3\%B3npara-el-desarrollo

Post, Marike. (1995). Fa d'Ambu, pp. 191-202. Pidgins and Creoles. An introduction. Ed. Jacques Arends, Pieter Muysken and Norval Smith. John Benjamins Publishing Company.

Prado Ballester, Cristián. (2007). La Etnografía de la Comunicación. Un modelo olvidado, pp. 1511-1522. Tomo II Actas del 6o Congreso Chileno de Antropología. https://www.aacademica.org/vi.congreso.chileno.de.antropolo gia/140

Programa de las Naciones Unidas para el Desarrollo. (2019). Objetivos de Desarrollo Sostenible. Recuperat el 20 de juliol de 2020 de www.undp.org/content/undp/es/home/sustainabledevelopment-goals.html

Proyecto Talis. (s/d). Asociación Proyecto Talis. Recuperat el 20 juliol de 2020 de http://proyectotalis.com/

Ramírez Olivero, Verónica. (2015). Análisis de la traducción y de la subtitulación de la serie "A to $Z$ » con Aegisub y Subtitle Workshop. Treball de fi de grau. Grado en Traducción e Interpretación. Curso Académico 2014-2015. Facultad de 
Traducción e interpretación. Universitat Autònoma de Barcelona.

Ramiro, Pedro. (2013). ¿Adónde va la cooperación internacional?. Revista Pueblos,

59. http://www.revistapueblos.org/blog/2013/12/05/adonde-va-lacooperacion-internacional/

Ramiro, Pedro i Pérez, Silvia. (2011). Sector privado y desarrollo: empresas, gobiernos y ONG ante las alianzas públicoprivadas. Centro de Documentación Hegoa, 28.

Ramos, Jamille. (2012). A recepção da dublagem e da legendagem no Brasil, pp. 1-11. Revista Vozes dos Vales da UFVJM: Publicações Acadêmicas, 2. Ministério da Educação. Universidade Federal dos Vales do Jequitinhonha e Mucuri UFVJM. Minas Gerais, Brasil.

Recasens, Andrés. (2018). Explorando los orígenes de la etnografía y su pertinencia, pp. 330-350. Revista Chilena de Antropología, 38.

Rees, T. (1993). Closed captions in the classroom. Article inèdit. Northampton, MA: International Language Institute of Massachusetts.

Reeves, Scott et al. (2008). Qualitative research: Qualitative research methodologies. Ethnography, pp. 512-514. BMJ. (Clinical research ed.), 337.

Requena, Pablo et al. (2009) Creencias, Representaciones y Saberes (CRS) de Profesores de Inglés como Lengua Extranjera, pp. 371-373. I Congreso Internacional de Investigación y Práctica Profesional en Psicología. XVI 
Jornadas de Investigación. Quinto Encuentro de Investigadores en Psicología del MERCOSUR. Facultad de Psicología. Universidad de Buenos Aires.

Restrepo, Eduardo. (2015). El proceso de investigación etnográfica: consideraciones éticas, pp. 162-179. Etnografías Contemporáneas,1(1).

Ribeiro de Souza, Luciana. (2015). São Tomé e Príncipe em dois momentos identitários. (Quinta seção: discurso, língua, pátria e ensino). Cadernos de Pós-Graduação em Letras (Mackenzie), 15(1).

Ribeiro Lóssio, Rúbia Aurenívia i de Mendoza Pereira, Cesar. (2007). A importância da valorização da cultura popular para o desenvolvimento local. III ENECULT - Encontro de Estudos Multidisciplinares em Cultura. Faculdade de Comunicação/ UFBa, Salvador-Bahia-Brasil.

Robertson, Linda i Hale, Beatrice. (2011). Interviewing Older People; Relationships in Qualitative Research. The Internet Journal of Allied Health Sciences and Practice, 9(1).

Rockwell, Elsie. (2009). La relevancia de la etnografía, pp. 17-39. La experiencia etnográfica: historia y cultura en los procesos educativos. Buenos Aires: Paidós.

Rodríguez Luna, María Elvira. (1997). La etnografía de la comunicación. Una perspectiva de la investigación sobre el lenguaje y la cultura, pp. 24-28. Enunciación. 2(1).

Rodríguez Sabiote, Clemente et al. (2005). Teoría y práctica del análisis de datos cualitativos. Proceso general y criterios de calidad, pp. 133-154. Revista Internacional de Ciencias 
Sociales y Humanidades, SOCIOTAM, 5(2). Universidad Autónoma de Tamaulipas Ciudad Victoria, México.

Rogers, Everett M. (1983). Diffusion of innovations. The American Center Library.

Romaine, Suzanne. (2004). The bilingual and multilingual community, pp. 385-403. The Handbook of Bilingualism. Tej K. Bhatia and William C. Ritchie. Blackwell publishing.

Romaine, Suzanne. (2002). The Impact of Language Policy on Endangered Languages, pp. 194-212. Protecting Endangered Minority Languages: Sociolinguistic Perspectives. International Journal on Multicultural Societies (IJMS) 4(2).

Romero, Ricardo. (2016). Colombia en su camino al bilingüismo, pp. 44-50. Perspectivas sobre la enseñanza del inglés. Ruta Maestra. Edición 16.

Romero Fresco, Pablo. (2013). Levantarse en Kibera. El País. Recuperat el 29 de juliol de 2020 de https://elpais.com/elpais/2013/03/27/africa_no_es_un_pais/13 64367600_136436.html

Ros Abaurrea, Alejandro. (2017). ClipFlair, Audiovisual Translation and Computer Assisted Language Learning: beyond the fourwalled classroom. Master's degree in Language Acquisition in Multilingual Settings (LAMS). University of the Basque Country.

Ruiz de Elvira, Álvaro P. (2011). Juego de tronos, primeras impresiones. El País. 
Ryang, Sonia. (2004). Chrysanthemum's Strange Life: Ruth Benedict in Postwar Japan. Occasional Paper 32. Japan Policy Research Institute. www.jpri.org/publications/occasionalpapers/op32.html

Sabariego-Puig, Marta et al. (2014). El análisis cualitativo de datos con ATLAS.ti, pp. 119-133. REIRE, Revista d'Innovació $i$ Recerca en Educació, 7(2).

Sáenz-Badillos, Ángel. (1998). Filología política: el hebreo, s/p. Recuperat el 20 de juliol de 2020 de https://www.nuevarevista.net/libros/filologia-politica-el-hebreo/

San Vicente, Francisco. Javier. (2010). Guía básica para el conocimiento de la investigación etnográfica. Recuperat el 20 de juliol de 2020 de openarchive.icomos.org/1792/1/Guia_basica_para_el_conoci miento_de_la_i.pdf

Sanahuja, José Antonio. (2007). ¿Más y mejor ayuda? La Declaración de París y las tendencias en la cooperación al desarrollo, pp. 71-101. Guerra y conflictos en el Siglo XXI: Tendencias globales. Anuario 2007-2008 del Centro de Educación e Investigación para la Paz (CEIPAZ). Coord. Manuela Mesa. Madrid, CEIPAZ.

Sánchez Rojo, Alberto. (2010). Educación intercultural. Hacia una convivencia pacífica en la escuela, pp. 1-31. Prisma social: revista de investigación social, 5 .

Santos García, Elisa i Romero Morante, Jesús. (2016). Educación para el desarrollo humano a través del cine: análisis de «Binta y la gran idea». Universidad de Cantabria. 
Scheer, Monique et al. (2010). "A Time Like No Other": The Impact of the Great War on European Anthropology, pp. 9-26. Doing Anthropology in Wartimes and War Zones. World War I and the Cultural Sciences in Europe. Eds. Reinhard Johler, Christian Marchetti, Monique Scheer.

Sedeño, Ana María. (2015). Prácticas de activismo audiovisual con objetivo de integración social: el caso del colectivo Cine sin Autor (CsA), pp. 181-192. Chasqui: Revista Latinoamericana de Comunicación, 129.

Seibert, Gerhard. (1997). Le massacre de février 1953 à São Tomé. Raison d'être du nationalisme santoméen, pp. 173-192. Lusotropicalisme: Idéologie coloniales et identités nationale dans les mondes lusophones. Lusotopie, 4.

Seibert, Gerhard. (2009). Santo Tomé y Príncipe: transformaciones políticas y socioeconómicas del periodo poscolonial, pp. 2336. Traducció: María Puy. Nova Africa, 24.

Seidman, Irving. (2013). Interviewing as qualitative research. New York. Teachers College Press.

Seiler, Frank-Ulrich. (2012). A cultura de escrita no quotidiano africano de São Tomé e Príncipe na fase colonial tardia. Actas do Colóquio Internacional sobre São Tomé e Príncipe numa perspectiva interdisciplinar, diacrónica e sincrónica. Seibert, Gerhard; Roque, Ana Cristina i Rosado Marques, Vítor. Instituto Universitário de Lisboa (ISCTE-IUL) - Centro de Estudos Africanos e Instituto de Investigação Científica Tropical (IICT). Recuperat el 20 de juliol de 2020 de https://coloquiostp.wordpress.com/ 
Silva, Petula i Mathias, Mércia. (2018). A etnografia e observação participante na pesquisa qualitativa, pp. 54-61. Ensaios pedagógicos (Sorocaba). 2(1).

Silverstein, M. (1979) Language structure and linguistic ideology, pp. 193-247. The Elentents: A parasession on linguistic units and levels. Eds. R. Clyne, W. Hanks i C. Hofbauer. Chicago: Chicago Linguistic Society.

Simango, Silvester Ron. (2009). Weaning Africa from Europe: toward a mother-tongue education policy in Southern Africa, pp. 201211. Languages and Education in Africa: a comparative and transdisciplinary analysis. Ed. Birgit Brock-Utne i Ingse Skattum. Bristol Papers in Education: comparative and international studies.

Sokoli, Stavroula. (2010). Learning via Subtitling (LVS): a tool for the creation of foreign language activities based on film subtitling. Mutra 2006- Multidimensional Translation: Audiovisual Translation Scenarios.

Soler Pardo, Betlem. (2017). La traducción audiovisual en la enseñanza de una LE: la subtitulación como herramienta metodológica para la adquisición de léxico, pp. 163-192. Tejuelo, 26.

Soriano, Ana María. (2015). Una mirada cualitativa al Proyecto de Revitalización del Náhuat, pp. 55-73. Diálogos. Universidad Don Bosco.

Swiggers, Pierre. (2019). Ideología lingüística: dimensiones metodológicas e históricas, pp. 9-40. Confluência. Revista do Instituto da Língua Portuguesa, 56. 
Szarkowska, A. i Gerber-Morón, O. (2018) Viewers can keep up with fast subtitles: Evidence from eye movements. PLoS ONE 13(6).https://journals. plos.org/plosone/article?id=10.1371/journ al.pone.0199331

Talaván, Noa (2011). Justificación teórico-práctica del uso de los subtítulos en la enseñanza-aprendizaje de idiomas, pp. 23-38. Trans. Revista de traductología (16).

Talaván, Noa (2011). La influencia efectiva de los subtítulos en el aprendizaje de lenguas extranjeras: análisis de investigaciones previas, pp. 265-282. Sendebar, 22.

Talaván, Noa (2013). La subtitulación en el aprendizaje de lenguas extranjeras. Barcelona: Octaedro.

Tambiah, Stanley J. (2002). Edmund Leach. An antropological life, pp. 1-6. Cambridge University Press.

Tassara, Carlo. (2017). Desarrollo y cooperación. Una historia abierta, pp. 7-13. Historia de la Cooperación Internacional desde una perspectiva crítica. Barranquilla, Col. Sello Editorial. Uniautónoma. Serie: debates RIACI. Ed. Rafael Domínguez i Gustavo Rodríguez Albor.

Teeter, Jennifer i Okazaki, Takayuki (2011). Ainu as a Heritage Language of Japan: History, Current State and Future of Ainu Language Policy and Education, pp. 96-114. Heritage Language Journal. 8(2).

Teillier, Fernando et al. (2016). De qué hablamos cuando hablamos de etnolingüística: bases teórico-metodológicas para un trabajo con el mapunzugun, pp. 137-161. RLA. Revista de Lingüística Teórica y Aplicada. 54(2). 
Terceiro Relatório Nacional dos Objectivos do Milénio. (2014). São Tomé.

Terrero Anguiano, Aitana. (2015). Los subtítulos como recurso didáctico para la enseñanza-aprendizaje de inglés en la etapa de educación secundaria. Trabajo de fin de máster. Universidad Internacional de La Rioja.

Tiainien, Tarja i Koivunen, Emma-Reetta. (2006). Exploring forms of triangulation to facilitate collaborative research practice: reflections on a multidisciplinary research group. Journal of Practice, 2. http://jrp.icaap.org/index.php/jrp/article/view/29

Tlaxcala. (s/d). Tlaxcala, la red internacional de traductores por la diversidad lingüística. Recuperat el 20 de juliol de 2020 de http://www.tlaxcala-int.org/

Torralba Miralles, Gloria. (2016). L'aprenentatge de llengües a través de la traducció audiovisual: la subtitulació com a eina per a l'adquisició de lèxic en llengua estrangera. Tesi doctoral. Universitat Jaume I.

Traduttori per la pace. (s/d). Traduttori per la pace. Recuperat el 20 de juliol de 2020 de https://traduttoriperlapace.wordpress.com/

Translators without borders. (2019). Translators without borders. Recuperat el 20 de juliol de 2020 de www.translatorswithoutborders.org

TV by the numbers. (2011). Updated: 'Game of Thrones' Ratings: Season One. Recuperat el 6 de juliol de 2020 de https://tvbythenumbers.zap2it.com/1/game-of-thrones-ratingsseason-one/ 
Tucker, Jeffrey. (1997). The Marshall Plan Myth. The Free Market, 15(9). mises.org/library/marshall-plan-myth

Tus Ojos. (s/d). Cine al servicio de la sociedad y la educación. Recuperat el 20 de juliol de 2020 de https://www.tusojos.es/

Ugwu, Chidi. (2016). History of ethnography: Straitening the records, pp. 77-81. International Journal of Sociology and Anthropology, 9(7).

UNESCO. (2002). Protecting Endangered Minority Languages: Sociolinguistic Perspectives. International Journal on Multicultural Societies (IJMS). 4(2).

UNESCO. (2003). Vitalidad y peligro de desaparición de las lenguas. Reunión Internacional de Expertos sobre el programa de la UNESCO «Salvaguardia de las Lenguas en Peligro». Grupo especial de expertos sobre las lenguas en peligro convocado por la UNESCO. Recuperat el 20 de juliol de 2020 de http://www.unesco.org/new/fileadmin/MULTIMEDIA/HQ/CLT/p df/LVE_Spanish_EDITED\%20FOR\%20PUBLICATION.pdf

UNESCO. (2006). Intergovernmental Conference on Language Policies in Africa. Harare, Zimbabwe, 17-21 March 1997. Final Report. Paris. Intangible Heritatge Section. Recuperat el 20 de juliol de 2020 de unesdoc.unesco.org/images/0014/001457/145746e.pdf

UNESCO. (2019a). 2019. Año Internacional de las Lenguas Indígenas. Recuperat el 20 de juliol de 2020 de https://es.iyil2019.org/

UNESCO. (2019b). Nigeria. Recuperat el 20 de juliol de 2020 de https://en.unesco.org/countries/nigeria 
UNESCO. (2019c). Pueblos indígenas. Recuperat el 22 de juliol de 2020 de https://es.unesco.org/indigenous-peoples/culture

UNESCO. (2019d). Sao Tome and Principe. Recuperat el 20 de juliol de 2020 de uis.unesco.org/country/ST

UNESCO. (2020). Evento de Alto Nivel "Construyendo un Decenio de Acciones para las Lenguas Indígenas", s/p. Recuperat el 20 de juliol de 2020 de https://es.unesco.org/events/eventoalto-nivel-construyendo-decenio-acciones-lenguas-indigenas

United Nations. (2018). Action plan for organizing the 2019 International Year of Indigenous Languages. Economic and Social Council.

United Nations. (2019). Lenguas indígenas, s/p. Foro Permanente para las Cuestiones Indígenas. Juntos lo logramos. Recuperat el 20 de juliol de 2020 de https://www.un.org/es/events/indigenousday/assets/pdf/Backg rounder-Languages-Spanish\%202019.pdf

Valverde, Paulo. (2000). Máscara, Mato e Morte em São Tomé: textos para una etnografia de São Tomé. Celta Editora.

Van Binsbergen, Wim (1994). Minority Language, Ethnicity and the State in Two African Situations: the Nkoya of Zambia and the Kalanga of Botswana, pp. 142-188. African Languages, Development and the State. Ed: Fardon, Richard i Furniss, Graham.

Vanderplank, Robert (1988). The value of teletext subtitles in language learning, pp. 272-281. ELT Journal 42(4). 
Veiga, Abel. (2019). "Tlundo" resiste como manifestação carnavalesca em STP. Téla nón. Recuperat el 20 de juliol de 2020

de

https://www.telanon.info/cultura/2019/03/05/28772/tlundo-

resiste-como-manifestacao-carnavalesca-em-stp/

Veiga, Abel. (2020). As Ilhas de STP ficaram mais pequenas. Téla nón. Recuperat el 16 d'octubre de 2020 de https://www.telanon.info/sociedade/2020/09/23/32609/asilhas-de-stp-ficaram-mais-pequenas

Vertimo studiju katedros. (2010). Subtitles and language learning. Vilnius, Lituània. Vilniaus universitetas filologijos fakultetas. Recuperat l'11 de setembre de 2020 de http://www.vsk.flf.vu.It/upl/File/SLL_project_description_EN.pdf

Wa Thiong'o, Ngũgĩ (1986). Decolonising the mind: the politics of language in African literature. Ed. London: James Currey; Nairobi: EAEP; Portsmouth: Heinemann.

Wardhaugh, Ronald. (2010). Planning, pp. 378- 408. An Introduction to Sociolinguistics. Wiley-Blackwell.

Whalen, D et al.(2016). Healing through language: positive physical health effects of indigenous language use. F1000 Research, 5. Recuperat el 20 de juliol de 2020 de https://f1000research.com/articles/5-852/v1

Williams, Rhiannon. (2014). Game of Thrones is still most pirated TV show. The Daily Telegraph. Recuperat el 20 de juliol de 2020 de

https://www.telegraph.co.uk/technology/news/10751891/Game -of-Thrones-still-most-pirated-TV-show.html 
World Economic Forum. (2016). 10 movies that changed the world. Recuperat el 20 de juliol de 2020 de www.weforum.org/agenda/2016/08/10-movies-that-changedthe-world

Wright, Wayne E. et al. (2015). The Handbook of Bilingual and Multilingual Education. Wiley- Blackwell.

d'Ydewalle, G. i Pavakanun, U. (1997). Could enjoying a movie lead to language acquisition?, pp. 145-155. New Horizons in Media Psychology. Eds. P. Winterhoff-Spurk i T. Van der Voort. Opladen, Alemanya: Westdeutscher-Verlag GmbH.

YFS. (2019). Yangon Film School. Myanmar. Recuperat el 20 de juliol de 2020 de http://yangonfilmschool.org/

Zuckermann, Ghil'ad i Monaghan, Paul. (2012). Revival Linguistics and the New Media: Talknology in the Service of Barngarla Language Reclamation, pp. 119-126. Language Endangerment in the 21st Century: Globalisation, Technology and New Media. Foundation for Endangered Languages, XVI Conference. AUT University.

Zuckermann, Ghil'ad i Walsh, Michael. (2011). Stop, Revive, Survive!: Lessons from the Hebrew Revival Applicable to the Reclamation, Maintenance and Empowerment of Aboriginal Languages and Cultures, pp. 111-127. Australian Journal of Linguistics, http://www.zuckermann.org/pdf/Revival_Linguistics.pdf

Zuckermann, Ghil'ad et al. (2014). Native Tongue Title: compansation for the loss of Aboriginal languages, pp. 55-71. Australian Aboriginal Studies. Journal of the Australian Institute of Aboriginal and Torres Strait Islander Studies, 1. 


\section{FILMOGRAFIA}

Brown T. i Nevins, S. (productores) i Obaid-Chinoy, S. (directora). (2015). A Girl in the River: The Price of Forgiveness [cinta cinematogràfica]. EEUU i Pakistan: HBO Documentary Films.

Cowperthwaite, G. i Oteyza, M. V. (productors) i Coperthwaite, G. (directora). (2013). Blackfish [cinta cinematogràfica]. EEUU: CNN Films.

Jego, Fitzgerald et al. (directors). (2016). Tribus XXI [sèrie documental]. França: Gedeon Media Group. Recuperat el 20 de juliol de 2020 de https://www.tv5unis.ca/tribus-xxi

Lima, São de Deus i Soares, Gerson (directors). (2016). Fitxicêlu. Crenças, Estigma e Ostracismo [documental]. São Tomé i Príncipe: Centro de Integridad Pública de STP. Recuperat el 24 d'agost de 2020 de https://www.youtube.com/watch?v=ZyB-uKVUad0\&t=1467s

Martínez, Jorge (director). (2016). Nómadas [documental]. Espanya: AECID.

Medeiros, Nilton (director). (2017). Serviçais da Memoria à Identidade [documental]. São Tomé i Príncipe.

Tiny, Silas (director). (2018). O Canto do Ossobó [documental]. Portugal. 